$$
\begin{gathered}
\text { UNIVERSIDADE DE SÃO PAULO } \\
\text { MUSEU DE ARQUEOLOGIA E ETNOLOGIA } \\
\text { PROGRAMA DE PÓS-GRADUAÇÃO EM ARQUEOLOGIA }
\end{gathered}
$$

\title{
AS ÁGUAS DO PASSADO E OS RESERVATÓRIOS DO GUARAÚ, ENGORDADOR E CABUÇU: \\ UM ESTUDO DE ARQUEOLOGIA INDUSTRIAL
}

Filomena Pugliese Fonseca 


$$
\begin{gathered}
\text { UNIVERSIDADE DE SÃO PAULO } \\
\text { MUSEU DE ARQUEOLOGIA E ETNOLOGIA } \\
\text { PROGRAMA DE PÓS-GRADUAÇÃO EM ARQUEOLOGIA }
\end{gathered}
$$

\title{
AS ÁGUAS DO PASSADO E OS RESERVATÓRIOS DO GUARAÚ, ENGORDADOR E CABUÇU: UM ESTUDO DE ARQUEOLOGIA INDUSTRIAL
}

Filomena Pugliese Fonseca

\begin{abstract}
Tese apresentada ao Programa de Doutorado em Arqueologia do Museu de Arqueologia e Etnologia da Universidade de São Paulo para obtenção do título de Doutor em Arqueologia.
\end{abstract}

Orientador: Prof ${ }^{\mathrm{a}}$ Dr ${ }^{\mathrm{a}}$ Dorath Pinto Uchôa

Co-orientador: Profo Dr José Manuel Lopes Cordeiro

Linha de Pesquisa: 5 - Espaço e Organização Social. 


\section{AGRADECIMENTOS}

À minha orientadora, Prof ${ }^{-a} r^{a}$ Dorath Pinto Uchôa, mestra e amiga, que acima de tudo nos transmite o que é mais importante: uma lição de vida.

Ao nosso co-orientador José Manuel Lopes Cordeiro, da Universidade do Minho, por sua generosa acolhida em Portugal, guiando seguramente nossos passos, através dos caminhos acadêmicos da arqueologia Industrial.

Ao CAPES, pelo apoio institucional, ao compreender a importância da pesquisa nesse ramo da ciência arqueológica, nos contemplando com uma bolsa de estudos, que nos possibilitou realizar plenamente os objetivos da pesquisa na Universidade do Minho, em Braga.

Ao Profo Dr José Luiz de Morais, diretor do M.A.E-USP, sempre disposto a solucionar nossas dúvidas, e com seu saber inconteste, tornar menos áridos os caminhos de nossa vida acadêmica.

À Prof ${ }^{\text {a }}$ Silvia Maranca, pela pertinência das sugestões, feitas durante nosso exame de qualificação, que certamente em muito contribuíram para aperfeiçoar nossa pesquisa.

Ao Eduardo Rodrigues Cruz, à Elisângela Moino, e à Sara Cristina Alves dos Santos, cujo apoio e dedicação foram fundamentais para a realização deste trabalho.

Aos engenheiros da Sabesp, ao Dr. Ronaldo Rocha, do Instituto de Pesquisas Tecnológicas de São Paulo, ao Dr. Marcelo Castejón, da Hagaplan, Engenharian Ltda., pela valiosa colaboração, com seus ensinamentos técnicos indispensáveis à compreensão da engenharia do abastecimento de água na cidade de São Paulo.

À minha família, a cada um de seus membros em particular e a todos os meus amigos, pela sua compreensão, desculpando-me pelas minhas ausências, mas seu amor e afeição, foram de vital importância para a realização de minha tese. 


\section{RESUMO}

Nesta tese, com a metodologia da Arqueologia Industrial, foi analisado o sistema de abastecimento de água na cidade de São Paulo, nos primórdios do século $\mathrm{XX}$, com o excepcional adensamento populacional do pequeno núcleo de estudantes, cujo destino de grande metrópole começava a delinear-se.

Com o abandono da solução mais viável, ou seja, o aproveitamento do rio Tietê, que cortava o planalto paulistano, mas que carregava consigo toda sorte de impurezas, a alternativa das autoridades encarregadas do saneamento, foi a introdução de barragens na Serra da Cantareira, com diferentes técnicas construtivas, formando lagos artificiais, cuja forma de armazenamento, águas estagnadas, era motivo de controvérsias entre, engenheiros, médicos e sanitaristas do mundo inteiro. Porém, foi essa a opção escolhida, na tentativa de dessedentar a população paulistana, que enfrentava em 1903, a pior estiagem de toda sua história.

Ao contrário dos outros dois reservatórios, Engordador e Guaraú, o do Cabuçu, já possuía ao nascer, os traços da notoriedade que ainda hoje o tornam admirável: a barragem foi projetada com o perfil prático do engenheiro norte-americano Edward Wegmann, revolucionário para a época, e que solucionou o problema do rompimento dos diques de contenção até então comuns, e por ter sido adotado pela primeira vez, no Brasil, o uso do concreto armado nas estruturas, e na construção de sua centenária adutora. Para o tratamento de suas águas, foi empregado de forma pioneira, o hipoclorito de sódio, que viria a eliminar, um grande número de doenças, que tinham na água um nexo causal, e finalmente, ao tornar o abastecimento menos elitizado, quando chegou aos bairros proletários, segregados espacialmente, e que até então, recebiam água em quantidade e qualidade não compatíveis com suas necessidades, transformando suas pobres habitações em moradias sem saúde.

Palavras chave: Arqueologia Industrial. Abastecimento de água. Lagos artificiais. Cabuçu. Segregação. 


\begin{abstract}
For this thesis we used Industrial Archeology methodology to analyze the water supply system for the city of São Paulo in the early $20^{\text {th }}$ century, a period during which population density was growing rapidly and what had been a small nucleus of students was clearly destined to become a major metropolis.

The most obvious solution, using water from the Tietê River that crossed the city, was abandoned as it carried with it all sorts of impurities. The health authorities decided to build damns in the Cantareira Mountains using a variety of building techniques. These damns created large reservoirs and, at the time, the fact that these stored stagnant water was a controversial issue among engineers, physicians and health professionals all over the world. However, this was the option selected to provide the population of the city with water, remembering that in 1903 it was experiencing the worst drought in all its history.

Contrary to other reservoirs - Engordador and Guaraú, from the start the Cabuçu Reservoir was known for its structure that, to this day, is admired. This Cabuçu Damn was designed by a practical US engineer by the name of Edward Wegmann. Wegmann's techniques were revolutionary for their time. In order to solve the problem of contention damns that often ruptured, he used reinforced concrete for the first time ever in Brazil. To treat the city's drinking water the authorities decided to use sodium hypochlorite for the first time. This would help eradicate a number of water borne diseases and bring treated waters to the masses. Before this treated water had been a privilege of the elite and the working classes were served with water in a volume and of a quality not compatible with their needs, resulting in households that were not only poor but also unhealthy.
\end{abstract}

Keywords: Industrial Archeology. Water supply. Reservoirs. Cabuçu. Segregation. 
SUMÁRIO

AGRADECIMENTOS

RESUMO

II

ABSTRACT

III

1 INTRODUÇÃO

1.1 Objetos de Estudo

1.2 Problemas $\ldots$

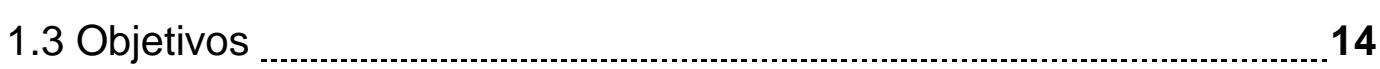

1.4 Justificativas

2 METODOLOGIA

2.1 Origem

2.3 Conceitos

2.4 Questões de método __ _ _ $\quad 27$

3 ARQUEOLOGIA DAS ÁGUAS PAULISTANAS ……................................ 35

3.1 Os reservatórios do Guaraú, Engordador e Cabuçu ...............................35

3.2 São Paulo e o abastecimento de água no alvorecer do século $X X \ldots . .37$

3.3 Lagos Artificiais - Algumas considerações …………............................... 59

3.4 As barragens da Cantareira

3.5 ENGORDADOR - Antecedentes históricos ............................................ 72

3.5.1 Pesquisa de Campo do Engordador ……………....................... 80

3.6 GUARAÚ - Antecedentes históricos ....................................................90

3.6.1 Pesquisa de Campo do Guaraú ....................................................... 97

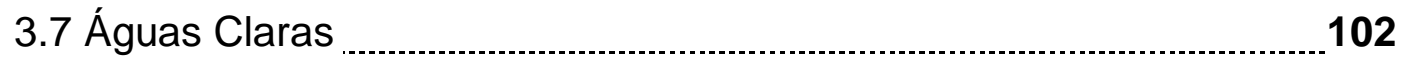


4.1. Localização e acesso 130

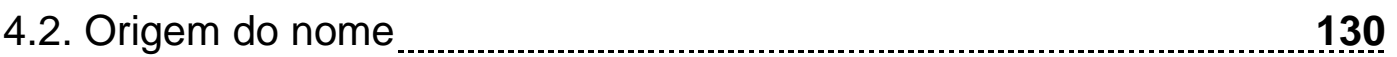

4.3. Adução do Cabuçu: um divisor de águas

4.4. Trabalho de campo 140

4.5. Zonas de distribuição do Cabuçu ......................................................... 152

4.6. Represa do Barrocada

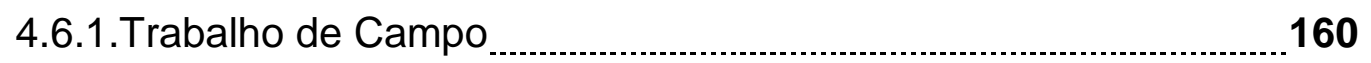

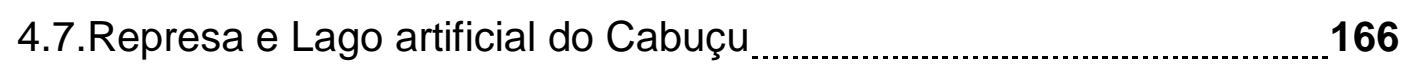

4.7.1.Recuperando um Patrimônio

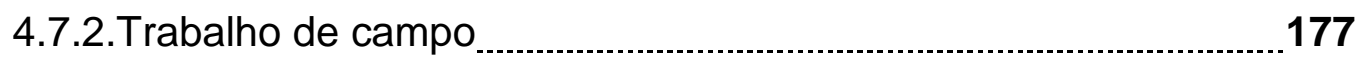

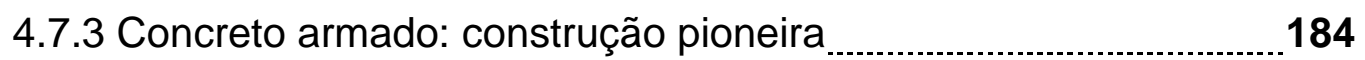

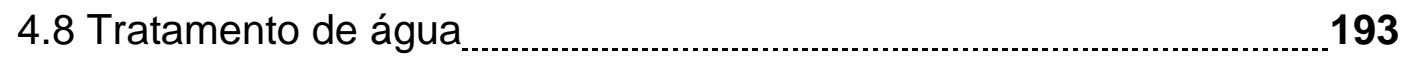

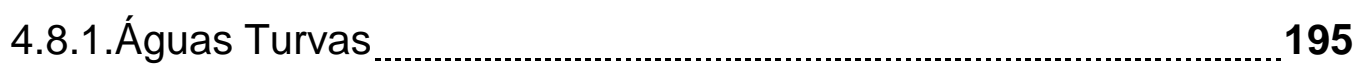

4.8.2. Hipoclorito de sódio: aplicação pioneira

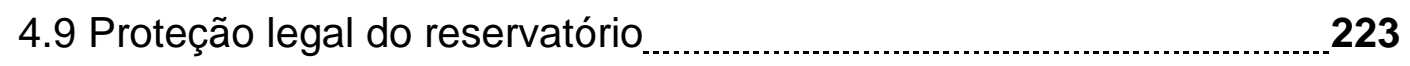

CONSIDERAÇÕES FINAIS

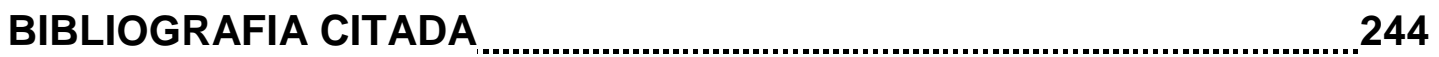

BIBLIOGRAFIA CONSULTADA

ANEXO 1 - Planta Reservatório do Cabuçu (Represa) .............................258

ANEXO 2 - Planta do Projeto Hidráulico do Canal Vertedor ...................259 


\section{INTRODUÇÃO}

O tema desta tese é o estudo histórico-arqueológico, à luz da metodologia da Arqueologia Industrial, do reservatório do Cabuçu', monumento arqueológico representante dos mais modernos sistemas construtivos de barragens que se praticavam no mundo, marco no abastecimento de água da cidade de São Paulo no começo do século XX e no panorama tecnológico do país.

Seu pioneirismo reside na construção em alvenaria, e na adoção de paredes perpendiculares, em forma elíptica, para resistirem à pressão das águas em tempos de cheia, e onde se empregou, de maneira revolucionária para a época, a técnica da introdução de armadura no concreto, o que constituiu um grande avanço tecnológico, por se tratar de um material que estava revolucionando a arte de construir, de aplicação recente, segundo os relatórios da Secretaria da Agricultura², e de grande durabilidade e solidez, como atestavam os jornais da época quando da inauguração do reservatório, em junho de 1908; o jornal O Estado de São Paulo, em manchete, anunciava: "Água para o ano 2000".3

A barragem do Cabuçu, formadora do lago artificial do Cabuçu, que mede 15 metros de altura e obedece ao perfil prático do engenheiro norte-americano Wegmann, foi construída em um estreitamento brusco do vale do rio do mesmo nome para armazenar $5.000 .000 \mathrm{~m}^{3}$ de água, dos quais 1.960 .000 eram destinados a uniformizar a descarga da linha adutora. A área inundada media $15 \mathrm{~km}$ e a maior sessão transversal, 850 metros.

Neste trabalho também foi feita a contextualização histórica do reservatório, no quadro do abastecimento de água da cidade de São Paulo, no começo do século $X X$, e sua relevância no panorama da engenharia de construção de barragens, cujo pioneirismo ainda se fez presente, mais de cem anos depois, quando, em 1999, foram iniciados estudos para reativação do uso da barragem, desta vez para

\footnotetext{
${ }^{1} A$ escolha do tema foi motivada pelo interesse em dar continuidade às pesquisas que desenvolvemos em nossa dissertação de mestrado, uma vez que, observamos a existência de uma lacuna em Arqueologia Industrial com relação às primeiras barragens para abastecimento de água no começo do século XX.

${ }^{2}$ Relatórios dos Negócios da Agricultura, Comércio e Obras Públicas do Estado de São Paulo, de 1903 a 1906.

${ }^{3}$ Jornal O Estado de São Paulo, São Paulo, 08/06/1908.
} 
contribuir no abastecimento de parte do Município de Guarulhos, área de intenso aumento populacional nos últimos anos.

No Cabuçu foi empregado pela primeira vez em 1925, o hipoclorito de sódio, considerado revolucionário e altamente eficaz na purificação das águas, esterilizando-as e livrando-as de substâncias estranhas, como é o caso do amoníaco, que alteravam seus caracteres organolépticos; o uso da cloração tornouse, logo após, obrigatório em todas as águas brasileiras.

Por esse motivo, foi feito um levantamento sobre o início dos processos de tratamento da água e sua desinfecção, o progresso de suas técnicas e como essa evolução colaborou para que fossem debelados os grandes flagelos que assolavam a cidade de São Paulo, os surtos epidêmicos das doenças de veiculação e transmissão hídrica, as chamadas "febres paulistas", que causavam um grande número de mortes, principalmente, nas camadas mais pobres da população.

O disposto no artigo 311 do Código Sanitário ${ }^{4}$, determinava que as autoridades deveriam fornecer água de boa qualidade à população, e a destinada aos usos domésticos deveria ser potável, e inteiramente insuspeita de poluição; porém, esse dispositivo legal não tinha ressonância em certos bairros, os chamados arrabaldes operários de São Paulo, situados para além do Tamanduateí.

O estudo compreende também, um resumo comparativo da técnica construtiva empregada nos outros dois lagos artificiais, o do Guaraú e do Engordador, e a polêmica que durou duas décadas, entre os que acatavam e os que se opunham ao sistema de represamento de córregos como meio de suavizar as crises do abastecimento, em razão das perigosas águas paradas, de difícil tratamento com os recursos de que se dispunha então. ${ }^{5}$

Aborda, ainda, sob o aspecto dos chamados equipamentos coletivos, a evolução urbana de São Paulo, onde a estratificação, marca registrada da cidade no

\footnotetext{
${ }^{4}$ São Paulo, Leis e Decretos. Decreto № 233 de 2 de Março de 1894. O Presidente do Estado, para a execução do artigo $3^{\circ}$ da Lei ํo 240 de 4 de Setembro de 1893, estabelece o Código Sanitário.

${ }^{5}$ Muito nos auxiliaram neste trabalho as linhas de pesquisa que conhecemos em nosso estágio em Portugal, que foram ampliadas, o que nos possibilitou realizar um levantamento dos riscos epidemiológicos associados do uso de águas residuárias no meio urbano, pela presença de agentes infecciosos e parasitários com os conhecimentos de que dispunha a microbiologia bacteriana no final do século XIX e começo do XX.

Esse estágio nos forneceu, também, subsídios teóricos, o que nos permite classificar a Arqueologia Industrial no Brasil não como uma disciplina temática relacionada com a evolução da atividade industrial durante os últimos cem anos e sim associada a um período arqueológico com fronteiras de estudos, cronológicas e espaciais definidas, integrando os monumentos industriais, como é o caso do Reservatório do Cabuçu, ao seu contexto espacial e histórico
} 
começo do século $\mathrm{XX}$, com a ocupação fragmentada e desigual de seu espaço, resultou na formação, entre outros, de bairros residenciais e operários, com grandes desigualdades em sua infra-estrutura, principalmente no que dizia respeito ao abastecimento de água.

A rápida transformação da cidade, tomando-se o ano de 1900 como marco cronológico indicativo dessa mudança, é atribuída a diversos fatores que a desencadearam, entre eles, a ascensão da lavoura do café, importante agente econômico na estruturação do processo de urbanização e cuja dinâmica foi determinada pelos vínculos com a produção e o comércio cafeeiros. Segundo Teodoro Sampaio, 1978, "o ressurgimento de São Paulo inicia-se com o café e consolida-se com ele". 6

Outra importante contribuição se deve à rede ferroviária, que vencendo longas distâncias, atuou como importante elo de ligação entre os centros da cafeicultura e os de consumo, e cujo ponto de encontro era a cidade de São Paulo, onde a economia foi redimensionada pela construção das estradas de ferro que por um lado, favoreceram o povoamento da cidade e, por outro, incentivaram a formação de bairros operários nas proximidades de suas estações.

O início da industrialização ratificou e consolidou a conformação urbana da cidade, mudança que na opinião unânime dos historiadores, se inicia com o Encilhamento, chamado por muitos de nuvem de papel, resultante dos capitais acumulados pela riqueza da cafeicultura, e que abriu perspectivas inteiramente novas à industrialização. Segundo CARONE, 1972, "A política de Rui Barbosa, facilitando a formação das sociedades anônimas, permite a multiplicação de empresas industriais pelo Brasil". ${ }^{7}$

A imigração estrangeira, por sua vez, tem relação direta com o crescimento demográfico de São Paulo, no final do século XIX e começo do XX, quando a cidade recebe grandes contingentes populacionais que se integravam à urbe paulistana, dando a ela um perfil cosmopolita.

O aumento da população no sítio urbano, acentuado a partir de 1890, quando se inicia a industrialização, é extraordinário: de menos de 240.000 habitantes, em 1900, a perto de 600.000, em 1920, provocando crescentes necessidades de

${ }^{6}$ SAMPAIO, Teodoro. São Paulo no Século XIX e outros ciclos históricos. Ed. Vozes Ltda. Petrópolis, Rio de Janeiro, 1978, p.87.

${ }^{7}$ CARONE, Edgard. A República Velha (Instituições e Classes Sociais). Ed. Difusão Européia do Livro. São Paulo, 1972, p.78. 
serviços públicos, principalmente os que diziam respeito ao fornecimento de água, o que tornou obsoletos os primitivos reservatórios, sistemas de adução, centrais elevatórias e o seu maquinário, então incapazes de satisfazer a procura crescente desse bem essencial. É preciso conhecer e estudar essa "indústria da água" para que se crie um programa de sensibilização para sua salvaguarda e proteção.

\subsection{Objetos de Estudo}

Estão divididos na tese, nos cinco tópicos seguintes:

\section{- Lagos Artificiais: Cabuçu, Engordador e Guaraú}

A formação dos lagos artificiais provocou uma polêmica entre cientistas, engenheiros e médicos sanitaristas com relação às águas armazenadas, que apodreciam, e os recursos ainda limitados (no final do século XIX e começo do XX) para sua desinfecção, trazendo como conseqüência as epidemias que grassavam em várias cidades nas quais os índices de mortalidade eram altos e alarmantes.

\section{- Sistema Cabuçu: captação e adução}

A barragem em forma elíptica, com grande capacidade de represamento das águas, a barragem do Cabuçu, introduziu uma técnica inovadora das mais modernas que se praticavam no mundo, resultado de equações matemáticas relativamente simples, que consistiam na distribuição da pressão nas paredes de alvenaria para a contenção das águas em época de enchentes, quando os reservatórios ficavam cheios, impedindo rupturas e vazão de grandes proporções do líquido armazenado. Seu pioneirismo também é notável por introduzir uma nova práxis construtiva, 0 concreto armado, na edificação de represas e barragens.

Extensa, a linha adutora do Ribeirão do Cabuçu, também em concreto armado, cujos vestígios materiais ainda se encontram na zona norte da cidade, segmentou-se em 28 aquedutos com a extensão total de $16.632 \mathrm{~m}$. Considerada uma grande obra de engenharia para a época, foi inaugurada a $1^{\circ}$ de Setembro de 1907. 
- Reservatório do Barrocada

Diante de uma nova crise no abastecimento, a barragem do Barrocada, inaugurada em 1912, contribuiu para aumentar o caudal da adutora do Cabuçu.

- Tratamento das águas: clarificadores e processos químicos

A introdução de processos químicos na desinfecção da água, a fim de diminuir a incidência das doenças de origem e veiculação hídrica, até a adoção obrigatória, em 1925, da cloração, em todo o território nacional, com o pioneirismo do reservatório do Cabuçu, na aplicação do hipoclorito de sódio. 


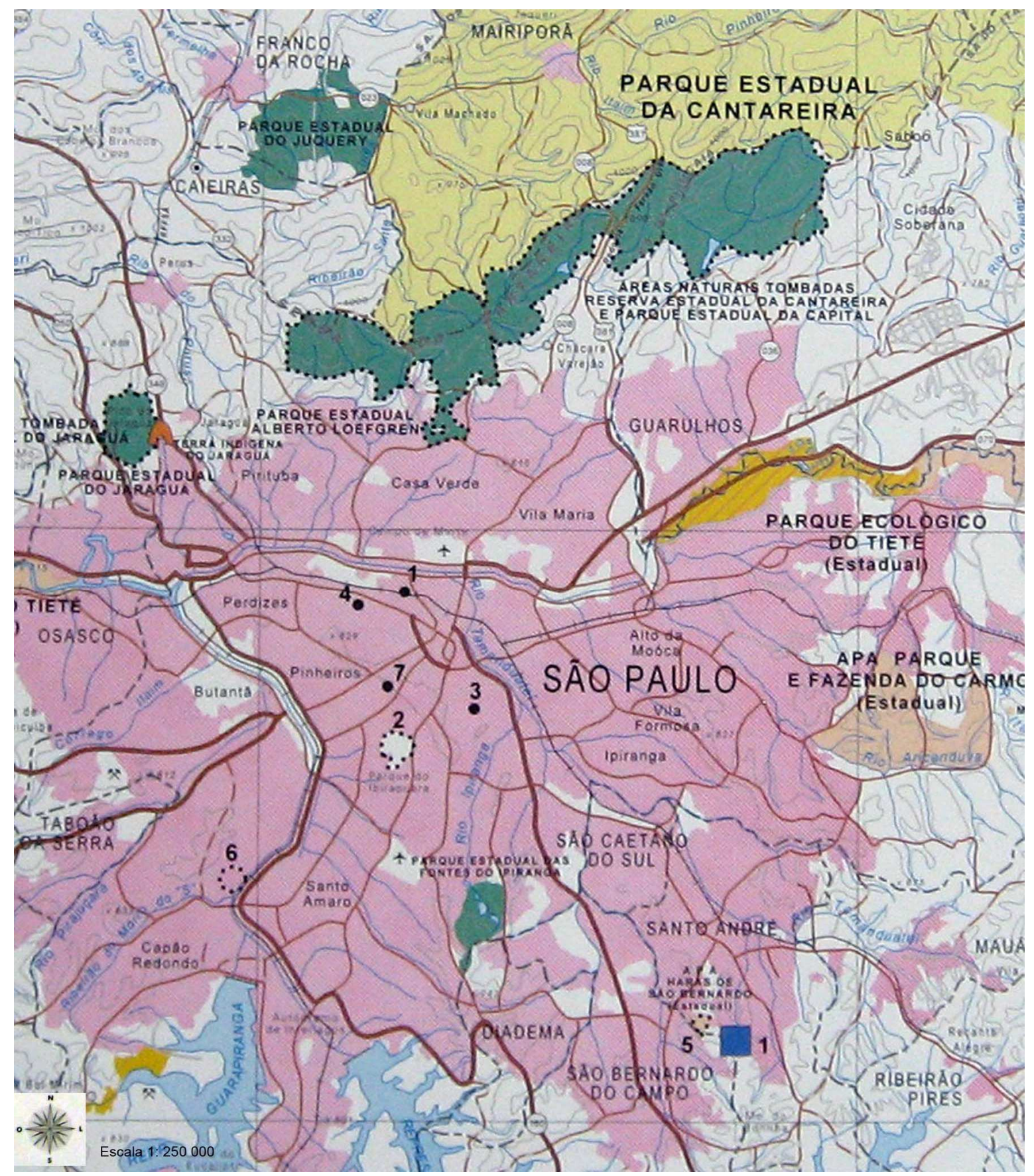

Atlas das Unidades de Conservação Ambiental do Estado de São Paulo São Paulo, Secretaria de Estado do Meio Ambiente, 2000

\subsection{Problemas}

Os seguintes questionamentos serão abordados ao longo do trabalho. 


\section{- Preservação somente em caso de reutilização}

Sistema de abastecimento de água para consumo humano é a instalação composta por conjunto de obras civis, materiais e equipamentos, destinados à produção e à distribuição canalizada de água potável para populações, sob a responsabilidade do poder público, ainda que administrada em regime de concessão ou permissão.

Um sistema de abastecimento de água é composto das seguintes unidades: manancial, captação, adução, tratamento, armazenamento, rede de distribuição, estações elevatórias e ramal predial.

As políticas urbanísticas de São Paulo, no final do século XIX e no começo do $X X$, estiveram associadas à criação de uma série de equipamentos e infraestruturas, ligadas à preocupação com a higiene e o bem-estar, que tinham caráter pontual e de pouca profundidade, beneficiando apenas uma parte da cidade; porém a população crescia e a conseqüente elevação do consumo de água exigia a criação de grandes obras, destinadas à captação, adução, armazenamento e técnicas de tratamento do precioso líquido, cujo progresso deveria se estender a toda a população paulistana.

O abastecimento de água e as canalizações utilizaram novos materiais, que o desenvolvimento técnico-científico-industrial pusera à disposição das sociedades. A essa construção de equipamentos urbanos, de caráter utilitário, chamamos de equipamentos coletivos.

É o caso da adutora do Cabuçu, obra com um componente técnico significativo para a época, no começo do século XX: a utilização do concreto armado em sua construção.

Esse relevante testemunho arqueológico das sociedades industriais, que completou cem anos em $1^{\circ}$ de setembro de 2007, contou, em sua inauguração, com a presença das mais altas autoridades: o Presidente do Estado de São Paulo, o Secretário da Agricultura e o Diretor da Repartição de Águas e Esgotos, além de insignes representantes da engenharia brasileira, que se deslocaram para a "longínqua" região do Cabuçu, em um trem especial lotado de pessoas importantes, para prestigiar tão significativo evento.

Com o passar dos anos, porém, tão importante adutora, que prestou serviços inestimáveis à população paulistana, sem função utilitária e sem possibilidade de 
reuso, foi abandonada à própria sorte. Encontram-se, hoje, seus vestígios espalhados pela zona norte da cidade, sem qualquer preocupação com sua preservação, mesmo por parte dos órgãos públicos, encarregados de fazê-la, condenando-se, assim, à destruição, um importante legado patrimonial e industrial tão representativo da conquista técnica da engenharia nacional, que foi a introdução do cimento armado nas tubulações, aduzindo água por gravidade para a zona baixa da cidade de São Paulo.

\section{- Democratização no abastecimento de água}

O abastecimento de água era elitizado até a captação do Cabuçu. Com ele veio a democratização no abastecimento.

Essa hipótese que estamos formulando tem seus fundamentos nas fontes primárias, nos diversos relatórios da Repartição de Águas e Esgotos e da própria Secretaria da Agricultura, e nos documentos desses órgãos sob a guarda do Arquivo do Estado, além das fontes secundárias, os inúmeros autores que, com diversos matizes, retratam a São Paulo do final dos oitocentos e começo dos novecentos.

A metrópole multicultural, ponto de concentração de pessoas e bens, começava a se esboçar com diversas modernidades, que não estavam ao alcance de toda a gama populacional. Surgiam bairros com infra-estrutura adequada aos desejos da elite, enquanto outras áreas continuavam à margem do progresso.

São Paulo se urbanizava, seguindo uma crescente estratificação social de seu espaço, cujas transformações, de forma sectária, relegavam os menos afortunados às terras mais baixas, até então abastecidas pelas mortíferas águas do poluído rio Tietê.

Crescia desordenadamente a ocupação das áreas de várzea, do outro lado do Tamandauteí que, à guisa de barreira aquática, separava os bairros mais nobres dos proletários Brás, Belém, Mooca e Penha, a zona baixa - na topografia do poder, a riqueza, nas terras altas e a miséria, nas baixas - que começou a ser abastecida com o reservatório do Cabuçu e cujo teor de potabilidade de suas águas estaria acima de qualquer suspeita.

O que existiria por trás dessa tentativa de tornar igualitário o abastecimento? 
Haveria apenas a preocupação de melhorar a qualidade da água que a população mais carente consumia? Ou o medo do contágio nas áreas urbanas pela classe dominante, através do contato entre o dono da fábrica e seus operários? Ou ainda um viés econômico, uma vez que a implantação de um serviço de abastecimento com águas salubres se traduz em um aumento de vida média da população servida, com diminuição da mortalidade em geral e da infantil em particular, o que acarretaria uma redução no número de horas perdidas com esses problemas?

\subsection{Objetivos}

Os Objetivos da tese são de dois tipos: Gerais e Operacionais.

\section{- Gerais}

- "Escavar" o reservatório do Cabuçu, um patrimônio industrial que, analisado, permite a transmissão de um saber técnico, por ser portador de um modelo de edificação, que significou, no começo do século XX, um avanço mundial na construção de barragens de concreto, e que seria adotado, pela primeira vez, no Brasil, na cidade de São Paulo.

- Comparar a técnica construtiva do Cabuçu com outros dois lagos artificiais: Guaraú e Engordador.

- Estudar a questão do tratamento da água que abastecia a cidade e os mitos ainda vigentes no final do século XIX e começo do XX, com relação aos locais de captação para garantir sua pureza, e quanto à teoria das emanações miasmáticas como causadoras das doenças infecciosas, derrubada pela pesquisa científica, que viria provar que são os microorganismos que as produzem e não os ambientes impuros das cidades.

- Investigar o emprego pela primeira vez do hipoclorito de sódio, na barragem como um meio eficaz de combate às bactérias.

- Registrar as alterações sofridas por esses bens ao longo do tempo. 


\section{- Operacionais}

- A análise com o método Arqueológico in situ da construção do reservatório do Cabuçu e o emprego pela primeira vez do concreto armado, em seu material de construção, suas dimensões, tubulações, rede de distribuição, resgatandose, dessa forma, sua importância como edificação utilitária.

- A contraposição, ainda com a mesma metodologia, do pioneirismo da técnica empregada no Cabuçu com o sistema construtivo dos dois reservatórios contemporâneos e situados na Serra da Cantareira.

- A demonstração de que, além de serem reservatórios de armazenamento, o Cabuçu e o Guaraú foram igualmente pioneiros como lagos de clarificação, na tentativa de garantir a limpidez e a pureza do líquido oferecido aos paulistanos.

- A explicação de que as intervenções de salvaguarda só foram possíveis em razão do progresso da ciência e da técnica, permitindo que a barragem chegasse aos nossos dias e ainda abastecesse uma zona com uma densidade populacional bastante elevada, como é o caso do Município de Guarulhos.

\subsection{Justificativas}

A importância e o significado do abastecimento de água aos núcleos populacionais tem vindo a ser salientada por diversos autores, que consideram este fato como o primeiro serviço de utilidade pública e, historicamente, como o principal problema urbano que se colocou ao desenvolvimento das sociedade. ${ }^{8}$ (CORDEIRO, 1993)

A Carta de Campinas, em defesa das construções e instalações utilitárias, no item 2 de suas considerações, declara:

O tombamento de bens culturais edificados obedece freqüentemente a critérios estéticos, resultando na conservação de edificações oficiais e particulares, fartamente decoradas e demonstradoras da riqueza de seus construtores. Em contrapartida as construções utilitárias (grifo nosso), que aliam a simplicidade e a

\footnotetext{
${ }^{8}$ CORDEIRO, José Manoel Lopes. Um serviço centenário: o abastecimento domiciliário de água à cidade do Porto (1887-1987), in Arqueologia Industrial. Museu da Indústria Têxtil da Bacia do Ave, Portugal, vol. 1, no 1-2, 1993, p.11.
} 
funcionalidade ao despojamento decorativo, são por isso freqüentemente negligenciadas. ${ }^{9}$

É o caso do Cabuçu, obra utilitária tão necessária ao desenvolvimento da cidade de São Paulo no início do século XX, e que representou um marco histórico na construção de reservatórios com grande capacidade de armazenamento, parte da memória do avanço da técnica e da engenharia de vanguarda paulistanas.

Enquanto engenheiros de países mais desenvolvidos não encontravam a equação matemática adequada para a construção de barragens, de ordem a não permitir a ruptura de suas paredes em conseqüência da grande pressão exercida pela água em época de enchentes, os engenheiros e técnicos da Repartição de Águas e Esgotos, R.A.E, numa largueza de visão sem precedentes, empregaram a teoria prática de Wegmann, construindo uma obra com técnica avançada para a época.

Justifica-se, portanto, plenamente o resgate arqueológico que pretendemos fazer dessa obra, que não obedece a critérios de imponência, grandiosidade ou monumentalidade. Como diz a Carta de Campinas, em seu artigo 12,

Se persistirem esses critérios seletivos, os historiadores da Técnica, da História Econômica, da Arqueologia Industrial, urbanistas e demais pesquisadores terão enormes dificuldades, pois encontrarão apenas edificações de grande porte, militares, religiosas ou residenciais, geralmente decoradas, faustosas, mas não encontrarão construções utilitárias, perdidas graças ao descaso. ${ }^{10}$

A preocupação preservacionista que se pretende com este trabalho, não se restringe apenas ao reservatório do Cabuçu como edificação utilitária, mas se estende também, à grande adutora de concreto armado, hoje abandonada, na zona Norte da cidade e no Município de Guarulhos, parte integrante da estrutura do sistema Cabuçu, que, em 1907, inaugurava uma nova era nos recursos da captação

\footnotetext{
${ }^{9}$ DECLARAÇÃO DO GEHT, em defesa das construções e instalações utilitárias ("Carta de Campinas") - UNICAMP, 1998. Os membros do Grupo de Estudos de História da Técnica-GEHT, (ligado ao Centro de Memória-CMU, da Universidade Estadual de Campinas-UNICAMP, Estado de São Paulo), reunidos em 19 de junho de 1997, 24 de julho, 18 de setembro, 13 de novembro e 11 de dezembro do mesmo ano, discutiram sobre a conservação dos bens culturais designados por "construções e instalações utilitárias", ligadas aos ofícios, às profissões, e às indústrias. Em 29 de janeiro de 1998 na última reunião do grupo resolveram elaborar uma Declaração do GEHT em defesa das construções e instalações utilitárias, que passou a ser conhecida como a "Carta de Campinas". Com esta Declaração, os membros do grupo de estudo da história da técnica, esperavam sensibilizar os profissionais ligados à conservação e pesquisa de bens culturais com relação à necessidade de se preservar a memória da produção industrial e seus testemunhos materiais

${ }^{10}$ Ibidem, Declaração do Geht, Campinas, São Paulo, 1998, p.4.
} 
e adução de água para o abastecimento de São Paulo, estendendo o "benefício" àquelas camadas da população que até então não o tinham usufruído.

Nessa data, quando eram diretores da Repartição de Águas e Esgoto Augusto Figueiredo e Arthur da Motta e chefe da Comissão de Obras Novas, Luiz Betim Pais Leme, foi aduzida a primeira etapa do Cabuçu (35.000 m²/dia). Essas águas foram captadas a uma altitude de $762 \mathrm{~m}$ e a linha adutora foi contruída para veicular 43.300m³/dia, com quase dezessete quilômetros de extensão, contituindo-se, com relação ao abastecimento de água, talvez a obra mais importante do Brasil, para a época.

Em 1912, a Repartição de Águas e Esgotos executou a segunda etapa, canalizando para essa adutora os recursos do vale do Barrocada, com a contribuição de 8.000 m³/dia.

Todas essas zonas foram interligadas por meio de estações elevatórias, de maneira a se socorrerem mutuamente, em caso de ruptura nos encanamentos.

A segunda idéia adotada, com relação ao abastecimento, foi a de que toda distribuição deveria ser feita diretamente pelo manancial, existindo um reservatório na extremidade da canalização para armazenar as águas em excesso durante as horas de pequeno consumo, e reinjetá-las na rede durante as horas de consumo máximo.

Essa disposição de alimentar uma rede por suas duas extremidades, além da grande vantagem de estabelecer uniformidade de pressões no encanamento, diminuía em muito o perigo de ruptura, permitindo uma redução sensível nos diâmetros das novas canalizações a serem estabelecidas, aumentando sensivelmente a capacidade das canalizações já existentes.

Essa comissão tinha em mãos um problema de difícil solução, em virtude de pareceres contraditórios ao projeto de formação de lagos artificiais como um novo gênero de captação, por serem suas águas paradas propícias à propagação de doenças como, febre tifóide e cólera, que dizimavam centenas de pessoas na Europa e nos Estados Unidos.

Segundo o Código Sanitário, ${ }^{11}$ a água destinada à população, sempre que possível, deveria provir de mananciais situados na serra, argumento usado pelos

\footnotetext{
${ }^{11}$ São Paulo, Leis e Decretos. Decreto $n^{\circ} 233$ de 2 de Março de 1894. O Presidente do Estado, para a execução do artigo $3^{\circ}$ da Lei ํㅜ 240 de 4 de Setembro de 1893, estabelece o Código Sanitário.
} 
críticos do projeto da Comissão que, desconsiderando-os, e fazendo prevalecer as opiniões favoráveis, inicia a construção dos reservatórios, medida eficaz para se formarem novas reservas destinadas a suprir a rede de distribuição em épocas de estiagem, garantindo, dessa forma, a capacidade efetiva das linhas adutoras.

Artigo 311. A água destinada aos usos domésticos deverá ser potável e inteiramente insuspeita de poluição.

Artigo 312. Provirá de manancial sempre que for possível com origem em serra. 


\section{METODOLOGIA ${ }^{12}$}

As sociedades modernas usufruem benefícios e um progresso material inegáveis, ambos resultantes da Revolução Industrial que, a partir de 1750, foi a responsável por um encadeamento de profundas mudanças na estrutura sócioeconômica mundial, em praticamente todas as áreas da vida social de quase todos os indivíduos, acarretadas pelo desenvolvimento da tecnologia.

O progresso industrial transformou, sem dúvida, o modus vivendi e o padrão de vida do homem ao longo dos últimos dois séculos. A enorme quantidade de bens produzidos alterou radicalmente o ambiente físico dos lares, a natureza das instituições políticas, o lazer e a recreação, o vestuário e, até mesmo, as normas de comportamento.

Embora constituindo apenas uma parte da complexa sociedade contemporânea, a indústria é, por certo, seu sistema de produção mais importante, assim como em outras épocas predominaram as corporações de ofício ou a escravatura. Por tudo isso os cientistas sociais chamam as sociedades modernas de "industriais".

Um dos traços mais marcantes do nosso sistema industrial, que contrasta essencialmente com outras estruturas de produção, é a invenção constante de novas máquinas, novos processos físicos ou químicos e novos princípios organizacionais.

Os impulsos desse extraordinário desenvolvimento surgem da busca empresarial de lucro e das conquistas tecnológicas: uma invenção conduz a uma outra, um novo princípio de organização desencadeia um outro e a introdução de um moderno processo químico pode sugerir um novo produto.

A procura constante por uma melhoria técnica não é recente, pois se perde nos tempos imemoriais, no cotidiano da humanidade, intervindo em sua vida cultural, social e econômica. Porém foi somente a partir da chamada Revolução Industrial que a técnica adquiriu a tonalidade mais forte de um dos agentes centrais do processo sócio-econômico moderno. Nesse movimento de âmbito internacional, ocorrido principalmente nas últimas décadas do século XIX e XX - este considerado

\footnotetext{
${ }^{12}$ Esta metodologia foi desenvolvida em conjunto com Dalmo Dippold Vilar, com base em nossos estudos de Arqueologia Industrial, na Universidade do Minho, em Portugal, sob a co-orientação do Professor Dr José Manuel Lopes Cordeiro, tendo sido também aplicada em sua tese: Água aos cântaros - Os Reservatórios da Cantareira: Um Estudo de Arqueologia Industrial.
} 
- século da chamada Terceira Revolução Industrial - cada vez mais os conhecimentos científicos passaram a ser aplicados ao sistema produtivo, bem como foram estabelecidas novas interações entre suas áreas. Associada à ciência, na forma de tecnologia, a Revolução transformou-se em um trunfo decisivo da competição industrial, da disseminação de novos produtos e de novas formas de comportamento.

As pequenas oficinas dos artesãos foram sendo substituídas pelas fábricas, as ferramentas simples, trocadas pelos novos equipamentos que haviam surgido. As tradicionais fontes de energia (água, vento e força muscular) foram superadas pelas máquinas a vapor e pela eletricidade. Houve um grande desenvolvimento dos meios de transporte e comunicação e um considerável acréscimo do controle capitalista sobre quase todos os ramos da indústria. A velha Europa agrária foi se tornando uma região com cidades populosas e industrializadas e esse modelo, cujas transformações implicaram uma nova organização social, expandiu-se por inúmeras regiões do mundo.

Portanto, nos últimos duzentos anos, assistimos a um avanço tecnológico sem precedentes na história da humanidade. Dessa forma, os vestígios materiais das fábricas, maquinários, sistemas de transporte e de abastecimento de água, entre outros, foram relegados na avançada marcha do progresso, havendo a necessidade de preservar-se esse passado onde seja possível, tornando-se fundamental que se estude e pesquise essa herança industrial para que futuras gerações compreendam de que forma chegou até nós e quais são seus similares.

Conforme CORDEIRO, 1994, as diferentes fases pelas quais passou o processo de industrialização proporcionaram à humanidade um importante legado patrimonial, que se materializa numa enorme diversidade de vestígios. ${ }^{13}$

Por outro lado, a rápida evolução tecnológica dos últimos decênios gera uma grande transformação industrial em um processo que, segundo Schumpeter, revoluciona incessantemente a estrutura econômica a partir de dentro, destruindo de maneira contínua o antigo, criando elementos novos, "a destruição criadora" ${ }^{14}$, que, aliada aos dois conflitos mundiais e a uma atitude cultural de indiferença, contribuiu para uma acentuada dilapidação do patrimônio industrial, que possui um valor social

\footnotetext{
${ }^{13}$ CORDEIRO, J.M.L. Arqueologia Industrial. Uma vertente fundamental da Arqueologia Urbana. In Encontro de Arqueologia Urbana, Braga, 1994, p.170.

${ }^{14}$ SCHUMPETER, J.A. Capitalismo, Socialismo e Democracia, Ed. Fundo de Cultura, Rio de Janeiro, 1961, p.106.
} 
como parte do registro de vidas de homens e mulheres e, como tal, proporciona um importante sentimento de identidade. Ao conteúdo universal dessa evidência, agregam-se também valores tecnológicos e científicos na história da produção, da engenharia, da construção e aqueles de caráter estético, determinados pela qualidade de sua arquitetura, desenho ou planificação.

Antigas instalações industriais, minas desativadas, moinhos, construções, canais para navegação, infra-estruturas de abastecimento de água, ferrovias, barcos e outros atualmente despertam interesse cultural e turístico, tornando-se profundamente significativos para um grande número de pessoas que os consideram como parte integrante de seu patrimônio cultural.

Ao longo dos últimos anos, em numerosos países industrializados, aumenta o interesse pela preservação dos vestígios de seu passado industrial. Dessa conscientização nasce igualmente uma reflexão sobre sua natureza, sobre quais desses vestígios devem ser conservados, sobre a importância de seus estudos e a sensibilização do público para sua preservação.

A salvaguarda das primeiras máquinas, a restauração e a reabilitação dos edifícios que as abrigam, o inventário da documentação social, econômica e técnica pertencem ao patrimônio coletivo de cada país, uma vez que ilustram uma grande parte de sua história nos últimos séculos.

As destruições muito numerosas e cotidianas dos produtos industriais, sítios, edifícios e demais estruturas, objetos, máquinas, manuais, catálogos, arquivos públicos e empresariais fazem com que desapareçam muito rapidamente os vestígios do passado industrial de um país.

A valorização dessa herança industrial pode ser traduzida de diferentes maneiras: pesquisas, levantamento e interpretação dos documentos arquivados, conservação, reciclagem e criação de museus, ecomuseus, museus de Ciência e Tecnologia e de Arqueologia Industrial.

A conservação do aludido patrimônio representa uma escolha da sociedade, cujo efeito repercutirá sobre as gerações vindouras, uma vez que implica uma conscientização de indivíduos ou de grupos sociais que vivem as contradições dos avanços tecnológicos do século XXI, o que dependerá de muitos fatores como, por exemplo, da importância histórica, arqueológica e arquitetural do monumento ou sítio, do seu estado de conservação, do potencial de sua manutenção e reuso, bem 
como da disponibilidade de fundos e do impacto econômico e social de sua valorização.

Segundo BUCHANAN, 1985, a ciência que tem um campo de estudo concernente a pesquisa, exame, levantamento, registro e, em certos casos, preservação dos monumentos industriais é a Arqueologia Industrial que visa, entre outros objetivos, evidenciar a importância desse patrimônio dentro do contexto da história social e da tecnologia. ${ }^{15}$

\subsection{Origem}

O termo Arqueologia Industrial foi empregado pela primeira vez em 1876, na França, pelo Barão de Verneilh, para propor o estudo arqueológico das forjas do Perigord e de Limoges, dos séculos XV ao XVIII, sem qualquer ligação necessária com a Revolução Industrial Inglesa.

Oliveira Martins, em 1884, quando diretor do Museu Industrial e Comercial da cidade do Porto, defendeu que nos Museus Industriais se expusessem objetos arqueológicos industriais, porém VITERBO, 1896, propõe a criação da Arqueologia Industrial para o estudo do passado fabril de Portugal, na tentativa de salvaguardar seu patrimônio quando enfatizava: "antes que tudo se perca irremediavelmente, salvemos pela descrição e pela estampa o que ainda resta, dilacerado e partido, dos antigos documentos da laboriosidade portuguesa". 16

Entretanto as pesquisas nesse campo científico não tiveram prosseguimento. Após a Segunda Guerra Mundial, com a reconstrução e a substituição de indústrias consideradas obsoletas, houve uma conscientização de que edifícios, maquinário e arquivos deveriam ser preservados como testemunhos da era industrial, inclusive aquelas unidades fabris ainda em fase de implantação nos primeiros anos do século XX, desaparecidas com os conflitos bélicos.

Somente na década de 1950, a expressão Industrial Archaeology foi empregada por Donald Dudley, professor da Universidade de Birmingham, e publicada pela primeira vez por Michael Rix, em 1955.

\footnotetext{
${ }^{15}$ BuChANAN, A. The Definition of Industrial Archaeology, In "L'étude et la Mise en Valeur du Patrimoine Industriel. 4" Confèrence internationale.Lyon-Grenoble, Septembre, 1981. Ed.du Centre National de La Recherche Scientifique, Paris, 1985, p.104.

${ }^{16}$ VITERBO, Souza Francisco. "Arqueologia Industrial Portuguesa; os moinhos". In O Arqueólogo Português, Vol II, no 8 e 9, 1896, p. 68 a 72.
} 
Este, em seu artigo The Amateur Historian, relaciona como campo de estudo, até aquele momento não explorado, uma série de monumentos pertencentes ao século XVIII e ao começo do século XIX: fábricas, máquinas a vapor, locomotivas, os primeiros edifícios com estrutura de metal, aquedutos e pontes de ferro fundido, os pioneiros empreendimentos em ferrovias, canais e eclusas. Faz então um alerta, para que sejam preservados em razão de estarem muitos deles ameaçados de destruição, conservando-se, se possível, a documentação ainda existente. $^{17}$

A constituição da Arqueologia Industrial como ciência dos vestígios deixados pelas sociedades industriais surgiu paralelamente às primeiras ações e medidas de proteção e preservação do patrimônio industrial, após a destruição do Palácio de Cristal do Porto, da gare de Euston Station, em 1962, dos pavilhões Halles Centrales de Baltard, em Paris, e a destruição parcial da antiga escola industrial Marquês de Pombal, em Alcântara, Portugal.

Ainda nessa década, introduzida por Angus Buchanan, essa nova disciplina passa a fazer parte da grade curricular da Universidade de Bath, concomitantemente com as primeiras sociedades conservacionistas, preocupadas com o patrimônio da indústria de mineração.

Esse movimento teve conotações diversas em vários países: na Inglaterra, ocorre um forte associativismo, com a Newcomen Society, centrada na história da engenharia e da tecnologia, que lança, em 1964, o Journal of Industrial Archaeology; e, em 1976, a Association for Industrial Archaeology, fundada três anos antes, inicia a publicação da Industrial Archaeology Review.

Em 1963, o poder público britânico, através do Conselho Britânico de Arqueologia e do Ministério de Obras Públicas, inicia um levantamento dos monumentos industriais, estabelecendo o NRIM, National Record of Industrial Monuments, que faz parte, desde 1981, da Real Comissão de Monumentos Históricos da Inglaterra.

CORDEIRO, $1994,{ }^{18}$ anotou que os movimentos de defesa do patrimônio em Portugal tiveram início no final da década de 1970. Em 1980, nesse país, surgiram vários projetos de investigação na área da manufatura do vidro e, em 1985, realizou-

\footnotetext{
${ }^{17}$ HUDSON, Kenneth. "Industrial Archaeology, an Introduction". 2 ${ }^{\mathrm{a}}$ ed. John Baker Publishers, London, 1966, p.11.

${ }^{18}$ CORDEIRO,José Manoel Lopes. Arqueologia Industrial, uma vertente fundamental da Arqueologia Urbana. Encontro de Arqueologia Urbana, Braga, 1994, p.169.
} 
se a Exposição de Arqueologia Industrial da Central do Tejo, marcante para a divulgação dos trabalhos desse novo campo científico.

Na França, o movimento teve início na década de 1960, quando os poderes públicos e a imprensa começaram a se preocupar com a preservação das ferrovias turísticas como a de Meyzieu, perto de Lyon. Foi o primeiro museu ferroviário da França acolhendo materiais antigos, salvaguardando-os e preservando-os, em funcionamento.

Em 1977, a Universidade Sorbonne, em Paris, criou um Centro de Arqueologia do Mundo Moderno, sob a direção de Philippe Bruneau, divulgando os trabalhos em andamento na área, através de uma revista anual. ${ }^{19}$

O museólogo Georges-Henri-Rivière contribuiu, com planos teóricos e práticos, para a criação dos primeiros ecomuseus, que promovem o encontro entre as ciências do homem e as da natureza, procurando popularizar a ciência e a tecnologia, em prol do desenvolvimento local. Ao lado deles, a fundação de museus específicos, como o "Museu do Ferro", criado em Jarville, perto de Nancy, em 1966, foi mais um dos esforços efetuados para apresentar os vestígios industriais ao público.

A inserção da Arqueologia Industrial na Alemanha deu-se em um contexto universitário no fim dos anos sessenta, passando a fazer parte dos currículos dos cursos de tecnologia, cuja preocupação com os monumentos, parte visível da herança industrial, permite reconstituir a atividade das forças produtivas na sociedade, bem como as condições sociais nas quais essas forças nasceram.

Em 1977, na Itália, nasceu o debate sobre Arqueologia Industrial, a denominação da disciplina, seu significado e a delimitação de seu campo de pesquisa, culminado, um ano depois, com a publicação de Introduzione alla archeologia industriale, por Franco Borsi. ${ }^{20}$

Nesse mesmo ano, a revista Abitare $^{21}$, em seu artigo Archeologia Industriale: Che Cos'è, um caso vivo da discutere: il Villaggio Leumann marca o início dos debates sobre a segregação espacial dos trabalhadores nas vilas operárias, sob a ótica dessa nova disciplina.

\footnotetext{
${ }^{19}$ BARRAL I ALTET, Xavier. L'Archéologie de l'age industriel, Archéologie et Industrie. In: Les Dossiers de L'Archéologie. Dijon: Faton, 1986.

${ }^{20}$ BARBIERI, Franco. "Archologia industriale e storia dell'arte". In Archeologia Industriale. Indagini sul território in Lombardia e Veneto. Edizioni Unicolpli., Milano, 1989 , p.7.

${ }^{21}$ ABITARE, no 158 , Milano, Ottobre 1977, p.76 a 95.
} 
Nos Estados Unidos, a Sociedade de Arqueologia Industrial surgiu em 1971, iniciando em 1975 a publicação do Journal of the Society for Industrial Archeology.

Ao longo dos anos, o campo de pesquisa da Arqueologia Industrial tornou-se mais abrangente estudando os vestígios materiais e imateriais do período da Revolução Industrial, embora existam grandes diferenças entre formas e períodos de implantação nos vários países.

Segundo BUCHANAN, 1972, para efeitos de periodização, a data de 1776 pode ser considerada como um marco da Revolução Industrial, ano de três grandes acontecimentos: a construção da ponte de ferro de Ironbridge ${ }^{22}$ da publicação de A Riqueza da Nações, de Adam Smith, e da Independência das Colônias Inglesas na América do Norte. ${ }^{23}$

\subsection{Conceitos}

Em sentido amplo, "Arqueologia Industrial é o estudo das causas, características e conseqüências da industrialização, baseado na identificação, registro, preservação e interpretação dos vestígios da indústria em seu contexto cultural e histórico". ${ }^{24}$ (ORSER, 2002)

Ramo especializado da Arqueologia, seu estudo procura abarcar as evidências tangíveis do desenvolvimento social, econômico e tecnológico do período que se inicia com a Revolução Industrial, para transcender em importância, o papel que desempenhou na sociedade, como testemunho histórico de um sistema que transformou a humanidade.

Para PALMER, 1990, o arqueólogo industrial pode considerar-se como o arqueólogo da sociedade industrial, não estudando seqüências de mudanças ao longo de um extenso período de tempo, como geralmente é realizado nas arqueologias de períodos mais remotos, o que é, no entanto, compensado pelo ritmo

\footnotetext{
${ }^{22}$ Condado de Shropshire, centro da Inglaterra, é o lugar onde a Revolução Industrial teve origem, com Abraham Darby, que em 1755 substituiu a utilização do carvão vegetal pelo coque, derivado do carvão mineral, na fundição de Coalbrookdale. Em Ironbridge, também foi construída a primeira ponte de ferro fundido do mundo, revolucionando o sistema construtivo empregado até então, com alvenaria ou madeira.

${ }^{23} \mathrm{KÜHL}$, Beatriz Mugayar. Arquitetura do Ferro e Arquitetura Ferroviária em São Paulo: Reflexões sobre a sua preservação. São Paulo: Ateliê FAPESP, Secretaria da Cultura, São Paulo, 1998, p.225. ${ }^{24}$ ORSER JR, Charles. Encyclopedia of historical archaeology, Ed.Charles, New York, Routledge, 2002, p.286.
} 
de desenvolvimento tecnológico extraordinariamente rápido desses dois últimos séculos, em comparação com o ocorrido em qualquer outro período do passado. ${ }^{25}$

O objeto das pesquisas da Arqueologia Industrial situa-se, cronologicamente, a partir da segunda metade do século XVIII; conseqüentemente, trabalha com um espaço de tempo mais exíguo, no qual existe, porém, uma enorme gama de documentos escritos e iconográficos, que são válidos, mas complementares, nunca substituindo as evidências arqueológicas na interpretação da cultura material das sociedades que passaram pelo processo da industrialização.

HUDSON, 1998, um dos importantes teóricos da Arqueologia Industrial, apresenta uma definição concisa do que seria a disciplina: a descoberta, registro e estudo dos resíduos físicos da indústria e meios de comunicação do passado. ${ }^{26}$

\begin{abstract}
A arqueologia industrial deve investigar todos os vestígios ou remanescentes do passado, que o aproximem ao máximo das atividades e das técnicas desenvolvidas pelo e para o homem, utilizando vários métodos para situá-las no tempo e no espaço. ${ }^{27}$ (PRADAYROL, 1985)
\end{abstract}

Portanto, não busca apenas retratar a história econômica e social de toda uma região ou de um país, a partir de documentos materiais descobertos através de pesquisas de exploração em superfície ou de escavações, mas, reencontrar as circunstâncias materiais e técnicas que estão na origem de uma fábrica, na montagem de uma máquina ou na construção de um estabelecimento, dos equipamentos coletivos, que marcaram a vida de seus contemporâneos e, em seguida, pesquisar as conseqüências que esses "acontecimentos" tiveram sobre todos os dados do ambiente de uma população ou grupo social. ${ }^{28}$

O abastecimento de água e toda sua estrutura como, por exemplo, açudes, comportas, barragens, aquedutos, adutoras, tubulações estão na categoria dos chamados equipamentos coletivos.

\footnotetext{
${ }^{25}$ PALMER, Marilyn. Industrial archaeology: a thematic or a period discipline? In Antiquity, Cambridge, 64 (243), 1990, p.281.

${ }^{26}$ HUDSON Keneth, Apud KÜHL, B.N. Arquitetura do ferro e Arquitetura Ferroviária em São Paulo: Reflexões sobre a sua preservação. São Paulo, Ed. Ateliê, 1998.

${ }^{27}$ PRADAYROL, Jacques. Les Chemins de Fer Touristiques Pionniers de L'Árchéologie Industrielle en France. In $4^{\mathrm{a}}$ Cenférence Internationale de Lyon-Grenoble, Éditions du Centre National de La Recherche Scientifique, Paris, 1985, p.79.

${ }^{28}$ PINARD, Jacques. L'archéologie industrielle. Presses Universitaires de France, Paris, 1985, p.6.
} 
Segundo Mendes, dessa vasta área também fazem parte o abastecimento e distribuição de energia, estruturas relativas ao fornecimento de gêneros alimentícios como mercados, armazéns e entrepostos; estabelecimentos das áreas de ensino e da saúde e estruturas de lazer, como cinemas, teatros, parques de diversão, estádios e outros. ${ }^{29}$

Mais que uma história das ciências e das técnicas, a Arqueologia Industrial procura reconstituir, a partir de elementos concretos, o espaço material e humano que envolve uma sociedade, seu patrimônio industrial, que merece ser estudado e preservado.

\subsection{Questões de método}

O objetivo da Arqueologia Industrial é a aproximação, em uma dimensão mais concreta, dos estudos de história econômica, social, das ciências e da tecnologia, baseia-se, sobretudo, nos artefatos, documentos de arquivos escritos e iconográficos e, da mesma forma, nos relevos topográficos e arquiteturais. Fundamentada sobre a multidisciplinaridade, utiliza as ciências do homem, como a arquitetura e a engenharia, incluindo expressamente todos os documentos e testemunhos pertencentes a essas disciplinas. ${ }^{30}$ (TROTTIER, 1987)

A Arqueologia Industrial, no estudo da cultura material, proporciona uma visão mais abrangente dos aspectos da produção, reprodução, distribuição e consumo de bens do sistema capitalista e as condições em que foram realizadas; portanto, com sua metodologia, analisa e interpreta, a partir dessas evidências materiais, as mudanças sociais, econômicas e culturais decorrentes do crescimento da organização capitalista na indústria.

Essa evolução, aumenta o número de temáticas a serem investigadas, ampliam-se as questões, fazem-se novas interrogações no campo da cultura material, definida por GLASSIE, 1998, "como aqueles segmentos da aprendizagem humana que proporcionam ao indivíduo planos, métodos e razões para produzir

\footnotetext{
${ }^{29}$ MENDES, José M. Amado. Património Industrial: um bem da comunidade ao alcance da escola. In Revista Munda ํㅜ 16, EditoraGAAC, Coimbra, 1988.

${ }^{30}$ TROTTIER, Louise. Lê patrimoine Industriel au Québec. Éd. Commission des biens cullturels du Québec, Canadá, 1987, p.15.
} 
coisas que se podem ver e tocar"31, e que. vem sendo progressivamente investigados e valorizados pela pesquisa, em vários domínios.

Para BRAUDEL, 1998, nossa sociedade pode ser definida, como a sociedade da "civilização material." 32

"Escusado será dizer que no estudo destas, como de outras temáticas, a arqueologia industrial pode prestar um excelente auxílio, especialmente no que toca à utilização de fontes materiais, com as quais está inteiramente relacionada”. ${ }^{33}$

Através de técnicas arqueológicas de resgate e documentação da cultura material, é que se pode pensar em salvaguardar e valorizar a herança industrial.

Para JORGE, 1987, a unidade informativa básica da Arqueologia advirá do estudo de áreas pesquisadas segundo seus dois vetores principais: diacrônico e espacial. $^{34}$

Seu objeto de estudo deve ser contextualizado no campo da História Social e da Tecnologia, definindo-se a Arqueologia Industrial, segundo BUCHANAN, "como matéria de equilíbrio entre a teoria e a prática das pesquisas que são ou deveriam ser complementares e não opostas entre teóricos ou historiadores e práticos ou arqueólogos". ${ }^{35}$ Hodder, corrobora com essa assertiva, quando afirma que a Arqueologia deveria restabelecer seus laços tradicionais com a História. ${ }^{36}$

Segundo Pradayrol, 1985, l'archéologie industrielle doit préserver un mélange indissociable de techniques, de méthodes, et de matériels, faits par l'homme et pour l'homme. ${ }^{37}$

A Arqueologia Industrial no estudo de toda evidência, material ou imaterial, de documentos, artefatos, estratigrafia e estruturas, assentamentos humanos em terrenos naturais e urbanos, criados por processos industriais ou para eles, faz uso

\footnotetext{
${ }^{31}$ MENDES, J. Amado. Apud, Construção Civil e Patrimônio Industrial. Revista Mundo, Editora Tipografia Comercial Coimbra, Coimbra, 1983, p.35.

${ }^{32}$ BRAUDEL, Fernand. Civilização Material, Economia e Capitalismo. Ed.Martins Fontes, São Paulo, 1998.

${ }^{33}$ MENDES, José Amado. A Arqueologia Industrial ao serviço da história local. In Revista de Guimarães, no 105, Guimarães, 1995, p.236.

${ }^{34}$ JORGE, Vitor Oliveira. Projectar o Passado. Ensaios sobre Arqueologia e Pré-História. Ed. Presença, Lisboa, 1987, p.75.

${ }^{35}$ BUCHANAN, Robert Angus. The Definition of Industrial Archeology in L'Étude et la Mise en valeur du Patrimoine Industriel. 4ํㅡㄹ Conférence internationale Lyon, Grenoble, Ed. du Centre National de la Recherche Scientifique, Paris, 1985, p.87.

${ }^{36}$ HODDER, lan. Interpretación En Arqueología.Corrientes Acutales. Ed. Crítica, Barcelona, 1994, p.93.

${ }^{37}$ PRADAYROL, Jacques. "Les chemins de Fer Touristiques". Pionniers de L'Archéologie Industrielle en France. In L'Étude et la Mise en valeur du Patrimoine Industriel. $4^{\circ}$ Conférence internationale Lyon, Grenoble, Ed. du Centre National de la Recherche Scientifique , Paris, 1985, p.79.
} 
dos métodos de investigação/pesquisa mais adequados para melhor entender o passado e o presente industriais. ${ }^{38}$

Por outro lado, sua metodologia não adota a escavação, como técnica de investigação, seus estudos se baseiam em pesquisas de superfície, em fontes documentais, vestígios de antigos maquinários, imóveis fabrís e nos equipamentos coletivos das sociedades industrializadas.

Sua variante metodológica aplicada a um tema específico, a indústria, utiliza como fontes essenciais e primárias os vestígios materiais que a história não pesquisa. Portanto, respaldada nos métodos arqueológicos de levantamento em campo, analisa o patrimônio industrial, em seu sentido lato, suas características funcionais desde sua origem e todas as transformações por ele sofridas. Pesquisa o desenvolvimento e aperfeiçoamento de processos tecnológicos, inserindo-os em seu contexto espaço-tempo, ao estudar as estruturas fabris, às vezes desaparecidas, ampliações e reduções da edificação, segundo a necessidade de cada época, materiais empregados, instrumentos, ferramentas e técnicas utilizadas.

Uma vez que a Arqueologia Industrial é 0 estudo dos vestígios remanescentes do passado industrial, the fieldwork is essentially an outdoor activity, can comprise locating, inspection, interpreting, surveying and measuring, and photographing or sketching industrial sites and structures. It is complementary to documentary work which in some cases might precede fieldwork, or in other instances follow it. ${ }^{39}$

A muldisciplinaridade de que faz uso a Arqueologia Industrial se imbrica e realiza sua síntese utilizando, portanto, o aporte de outras ciências como a geografia física e econômica, a química, a física, o direito, a história social, econômica, do trabalho, das ciências, da técnica, da engenharia, da arte, da arquitetura, das cidades e outras e, por esse motivo, o estudo do mecanismo de interpretação de disciplinas, algumas vezes afastadas umas das outras, se restringe ao ponto de vista prático e metodológico da investigação.

\footnotetext{
${ }^{38}$ Carta de Nizhny Tagil de 2003, sobre o Patrimônio Industrial, elaborada pelo TICCIH (The International Committee for the Conservation of the Industrial Heritage, O TICCIH, é a organização mundial encarregada do patrimônio industrial, e assessor especial de ICOMOS nessas questões. $O$ texto desta carta foi aprovado pelos delegados reunidos na Assembléia Nacional do $\mathrm{TICCIH}$, de caráter trienal, que teve lugar em Moscou a 17 de julho de 2003. No Brasil, a seção nacional deste Comitê, foi inaugurada em Novembro de 2004, na UNICAMP - Campinas - São Paulo.

${ }^{39}$ JONES, William. Dictionary of Industrial Archaeology. $2^{\circ}$ ed., Sutton Publishing. London, U.K., 2006, p.136.
} 
Complementa-se o trabalho de campo, com a consulta a outras fontes, como documentos escritos e iconográficos que incluem: atos oficiais, decretos e leis, relatórios de órgãos públicos do poder Executivo, catálogos, correspondência interna das empresas, atas de assembléia, manuscritos, projetos de invenções, anuários estatísticos, propagandas, estatutos societários (contratos), solicitação e registro de patentes, plantas, mapas, croquis, desenhos, telas, fotografias, e outros.

Tais fontes podem ser encontradas nos arquivos públicos, porém, parte dessa documentação ainda está em mãos de particulares, cujo acesso depende da postura dos proprietários com relação à sua salvaguarda.

Completa-se o estudo, com a pesquisa em jornais, revistas técnicas, microfilmagens, biografias, teses, visitas a museus, cujo acervo preserva ferramentas, antigas máquinas, veículos, moldes de artefatos industriais, desenhos, artes e ofícios, filmes e vídeos, que documentam um processo ou uma técnica de produção já desaparecidos, além do inquérito oral. ${ }^{40}$

A metodologia compreende a investigação e a análise de tipo do monumento ou estrutura em uma perspectiva regional e nacional, diacrônica e espacial e o estudo de seus aspectos tecnológicos, econômicos ou humanos. Ambas as estratégias metodológicas envolvem pesquisas em vários tipos de fontes, que se complementam, mas cujo resultado final está relacionado com o exame, estudo, observação e avaliação dos vestígios materiais.

O arqueólogo industrial trabalha, como qualquer outro arqueólogo, com evidências de campo e, para efeito desta tese, respaldados nos autores anteriormente citados, conciliou-se o método arqueológico de campo - pesquisa, estudo e registro, com a vertente histórica da interpretação das fontes materiais e documentais que se encontravam disponíveis, de forma a reconstituir uma visão panorâmica da infra-estrutura do abastecimento de água na cidade de São Paulo, no final do século XIX e início do XX. ${ }^{41}$ (BUCHANAN, 1985)

Por intervenção arqueológica não deve se entender apenas a prospecção no subsolo.

\footnotetext{
${ }^{40}$ PANNELL, J.P.M. The Techniques of Industrial Archaeology. Ed. by J.Kenneth Major. Great Britain., 1974.

${ }^{41}$ BUCHANAN, Robert Angus. The Definition of Industrial Archeology in L'Étude et la Mise en valeur du Patrimoine Industriel. 4ํㅡㄹ Conférence internationale Lyon, Grenoble, Ed. du Centre National de la Recherche Scientifique, Paris, 1985, p.86.
} 
(...) a arqueologia não tem um único método, mas vários; e a arqueologia industrial, como arqueologia que é, tem apenas a marcála a diferença de muitos dos seus vestígios se encontrarem à superfície, dispensando assim, na maioria dos casos, a utilização de técnicas de escavação. ${ }^{42}$ (RIBEIRO, 1990)

A investigação arqueológica dos sítios se processou em três níveis: o construído, o lugar e o território, com a análise e avaliação do patrimônio para o esclarecimento e a compreensão desses equipamentos coletivos industriais do passado, consistindo na pesquisa dos vestígios de superfície que, ao serem investigados, permitiram extrair informação elucidativa acerca dos tipos de materiais empregados e sua evolução à luz da seqüência lógica do devir temporal. ${ }^{43}$

Ao contrário de vestígios arqueológicos de estruturas menos visíveis, o conjunto das edificações, objeto deste estudo, inserido na paisagem, não exigiu trabalho de escavação. Para descrição e localização geográfica do sítio industrial, utilizou-se cartas topográficas, hidrográficas antigas e atuais, fotografias de satélite e aéreas para georeferenciá-lo. Foram feitas, também em campo, medições nas construções, levantamento fotográfico do sistema construtivo e a análise de seu estado atual, de materiais e tecnologia utilizados em sua construção, acréscimos e modificações que sofreram por ações antrópicas ou não, e também, comparações com outras estruturas similares.

Portanto, é no trabalho de campo que reside a grande força das técnicas de investigação da Arqueologia Industrial. A análise do vestígio material deverá ser a mais detalhada e minuciosa possível, com a elaboração de fichas de inventário com vista ao estabelecimento de um diagnóstico para a compreensão de sua situação atual, fornecendo as bases que possibilitem avaliar o objeto de estudo durante seu período de vida.

Equipamento coletivo, o abastecimento de água, é também considerado obra pública e, segundo Ordónez, 1990, “desde tiempo immemorial, por medio de las Obras Públicas, el hombre configura el espacio y se apropía de él, lo señala y significa creando um lugar em sentido heideggeriano. Em effecto, las Obras

\footnotetext{
${ }^{42}$ RIBEIRO, Isabel e SANTOS, Luísa. A indústria do papel na perspectiva da Arqueologia Industrial. In I Encontro Nacional sobre o Património Industrial. Editora Coimbra, Coimbra, 1990, p. 485.

${ }^{43}$ Segundo Engels "para a dialética não há nada de definitivo, de absoluto, de sagrado; apresenta a caducidade de todas as coisas e em todas as coisas e, para ela, nada existe além do processo ininterrupto do devir e do transitório. Nada é sagrado significa que nada é imutável, que nada escapa ao movimento, à mudança. Devir expressa que tudo tem uma 'história'”. ENGELS, Friedrich apud LAKATOS, Eva Maria. Fundamentos de Metodologia Científica, São Paulo, ed Atlas, 1991, p.103.
} 
Públicas no son solo monnumentos aislados em la naturaleza, sino que forman um tejido que soporta $y$ hace posibles las relaciones sociales, y tienen um valor arqueológico, simbólico, estético, histórico, tecnológico y funcional que nos obligan a uma preservación inteligente". 44

Para a interpretação dos vestígios do abastecimento de água, foi necessário um levantamento dos arquivos públicos e privados, a fim de que o estudo pudesse ser elaborado de forma mais precisa e sistemática possível, para sua contextualização no espaço e no tempo, o que permitiu um maior conhecimento das técnicas, processos e métodos de trabalho empregados.

A arqueologia industrial deve seguir os preceitos do pósprocessualismo, exercitando constantemente a compreensão da interação do passado no presente entre indivíduos e sociedades e a cultura material que as produziu e as envolve, de acordo com lan Hodder. ${ }^{45}$ (JAUME, 2004)

Portanto, sendo sua maior interface com a História, no estudo da cultura material das sociedades industrializadas, associa os métodos arqueológicos aos históricos regressivo, progressivo e comparativo.

O método regressivo, importante auxiliar na Arqueologia Industrial, assenta suas bases no procedimento regressivo que havia sido aplicado às presenças agrárias na França por Marc Bloch, em 1935. ${ }^{46}$ Segundo Custódio, utilizando este método, "o arqueólogo industrial tem apenas que saber interpretar os dados fornecidos pelas presenças físicas que se encontram no terreno e delas fazer o instrumento de clarificação do lugar". 47

O método regressivo, partindo de um presente que se oferece para um passado pouco conhecido, constitui um tipo de investigação que se processa no sentido inverso do tempo, ou seja, tal como nos diz MARCH BLOCH, 1935, (...) "só

\footnotetext{
${ }^{44}$ ORDÓNEZ, José Antonio Fernández. "Informe sobre la situación de la Arqueología Industrial y el Patrimonio de Obras Públicas en los países europeos del Mediterráneo y propuestas de acciojnes a emprender para su conservación y reutilización", In Mercedes Lopez Garcia. La Obra Publica, Investigacion y Practica. I Encontro Nacional sobre o Património Industrial. Vol.II, Ed. Coimbra, Coimbra, 1990, p.281.

${ }^{45}$ JAUME, Valentines Alvarez. Arqueologia Industrial I Ecomuseografia a Les Universitats. El Cãs de L'ETSEIB, In Quaderns d'Història de L'Enginyeria. Vol. VI, Barcelona, 2004, p.140.

${ }^{46} \mathrm{BLOCH}$, Marc. Caractéres Originaux de L'Histoire Rurale Française. Paris, 1935, p.86.

${ }^{47}$ CUSTÓDIO, Jorge. Método Comparativo e Método Regressivo na Detecção do Moinho Gigante do Barão do Sobral erigido no Barreiro. In I Encontro Nacional sobre o Património Industrial, Editora Coimbra, vol. II, 1990, p.744.
} 
está intacta a última película. Para reconstruir os vestígios apagados dos restantes é forçoso primeiro desbobinar a película no sentido inverso das filmagens."48

Utilizando o método regressivo na análise dos vestígios industriais legados durante esses últimos duzentos anos, partimos do presente para o passado, estudando simultaneamente os gestos e os hábitos inerentes à atual sociedade capitalista.

Percebemos a interligação com a Revolução Industrial, ou seja, a mecanização dos nossos hábitos e a medição individual do tempo ligada ao modo de produção, com a banalização dos bens e com a necessidade de substituição constante dos produtos, cada vez mais diversos e condicionantes da mutação do nosso cotidiano. ${ }^{49}$

O método comparativo, de larga aplicação nas vários ramos das ciências, realiza analogias, tendentes a apontar as similitudes e explicar as divergências. Permite, uma análise das técnicas, e da tecnologia empregadas em outras realidades, e em outros momentos históricos, estudando os meios que o homem descobriu e utilizou para melhorar as condições de sua existência: as circunstâncias da invenção, sua transmissão coletiva e as relações entre ciência e técnica. ${ }^{50}$

Esse método, segundo Custódio ${ }^{51}$, deve ser utilizado para se estabelecerem os paralelos tecnológicos do objeto em estudo, sendo possível levar mais longe o diagnóstico, no sentido de proporcionar uma maior compreensão das relações que se estabelecem entre história, indústria, técnica e cultura.

A aplicação simultânea dos métodos comparativo e regressivo deve ser acompanhada da pesquisa e do estudo de documentos escritos e iconográficos. Quanto maior for o leque de informações que se possa recolher sobre o objeto em análise, tanto mais acurada poderá ser sua interpretação.

A partir desse momento, propõe-se a utilização do método progressivo, ${ }^{52}$ isto é, volta-se ao presente, a partir do passado já decifrado, compreendendo-se, enfim,

\footnotetext{
${ }^{48}$ HENRIQUES, Isabel. A Fábrica da Companhia de Cerâmica de Telheiras. Algumas questões de método. In I Encontro Nacional sobre o Património Industrial. Ed.Coimbra, Coimbra, 1990, p.211.

${ }^{49}$ FOLGADO, Deolinda. Instituto Português do Património Arquitectónico: Inventário do Património Industrial. In Património Edificado.Novas Tecnologias.Inventários.Editora do Instituto Açoriano de Cultura. Angra do Heroísmo, 2002, p.215.

${ }^{50}$ DUMAS, Maurice, apud ANDRIEUX, Jean-Ýves. "Que sais-je? Le Patrimoine Industriel. Presses. Universitaires de France, Paris, France, 1992, p.105.

${ }^{51}$ CUSTÓDIO, Jorge. Método Comparativo e Método Regressivo na detecção do Moinho Gigante do Barão do Sobral, erigido no Barreiro. In I Encontro Nacional sobre o Património Industrial. Vol II, Editora Coimbra, Coimbra, 1990, p.745.

${ }^{52}$ LEFĖBVRE, Henry. De lo Rural a lo Urbano. Ed. Península, Barcelona, 1978, p.2.
} 
o tempo em que se altera a própria história, nesse espaço em transformação, que é a cidade de São Paulo do final do século XIX e começo do XX, despontando para uma metrópole industrial onde, de acordo com o método de Lefebvre, existem três espacialidades: a primeira, da localidade (rural); a segunda, do bairro (industrial) e a terceira, da porção imersa na metrópole (serviços). ${ }^{53}$

Portanto, nessa trialética, passado, presente e futuro, se delineiam os caminhos da mudança, atribuindo-se à industrialização fator de importância capital nas reformulações tecnológica, econômica, social e filosófica das sociedades modernas.

Podemos entender a Arqueologia Industrial como um elo que nos liga ao passado e, simultaneamente, nos projeta no futuro, tornando o arqueólogo industrial um personagem interveniente, com papel ativo a desempenhar nos quadros da sociedade atual. ${ }^{54}$

\footnotetext{
${ }^{53}$ LEFÉBVRE, Henry. A Revolução Urbana. Ed. UFMG, Belo Horizonte, 2004, p.44/445.

${ }^{54}$ RIBEIRO, Isabel e SANTOS, Luísa. A indústria do papel na perspectiva da Arqueologia Industrial. In I Encontro Nacional sobre o Património Industrial. Editora Coimbra, Coimbra, 1990, p. 485.
} 


\section{ARQUEOLOGIA DAS ÁGUAS PAULISTANAS}

\subsection{Os reservatórios do Guaraú, Engordador e Cabuçu}

É no trabalho de campo que reside a grande força das técnicas de investigação arqueológica e, por via de conseqüência, da arqueologia industrial.

No caso específico, este trabalho consistiu no estudo in situ dos reservatórios do Cabuçu e Engordador, procedendo-se ao geo-referenciamento de cada unidade, ao levantamento fotográfico, e, no caso do Guaraú que foi totalmente destruído em 1974, ao inquérito oral com funcionários da SABESP, em especial com o engenheiro Edgard Nardini de Lima, gerente da Estação de Tratamento do Guaraú, há 30 anos na Empresa, cujo pai trabalhou no mesmo local em que ficava o antigo reservatório e seu clarificador. Importantes informações foram fornecidas, como sua exata localização e o curso do ribeirão Guaraú onde, ainda, podem-se encontrar vestígios de sua captação para a formação do antigo lago artificial.

Nos outros dois reservatórios, do Engordador e do Cabuçu, foram também analisados, os equipamentos adotados em suas estruturas, a técnica construtiva e os materiais utilizados em sua construção, dimensões e capacidade de armazenamento dos lagos, seu funcionamento, ornamentações, patologias, transformações ao longo do tempo, o registro das intervenções que sofreram, fazendo-se um estudo comparativo entre as fotografias antigas da época de sua construção com as atuais: no solo e aéreas, constituindo-se a fotografia, importante auxiliar dos procedimentos metodológicos que permitiram o estudo comparativo das condições dos reservatórios no início de sua construção em 1907, e seu estado atual.

Como o saneamento e o abastecimento de água estão na esfera de atuação do Poder Público, numa segunda fase, com a complementaridade das fontes históricas, procedeu-se a uma "escavação" não só na documentação oficial, dos relatórios da Secretaria da Agricultura, Comércio e Obras Públicas do Estado de São Paulo, de 1894 a 1914, ${ }^{55}$ órgão ao qual estava subordinada a Repartição de Águas e

\footnotetext{
${ }^{55}$ Salientamos a existência de três tipos de relatórios anuais e referentes ao mesmo período: um realizado pela R.A.E. , através de seu Diretor e encaminhado ao Secretário da Agricultura Comércio e Obras Públicas do Estado, mais técnico, descritivo e detalhado, e outro enviado por este Secretário ao Presidente do Estado de São Paulo, com considerações pessoais sobre o andamento das obras e as providências solicitadas ao Presidente para o sucesso das empreitadas, que, por sua vez, enviava mensagem ao Congresso Legislativo, justificando a liberação de verbas.
} 
Esgotos de São Paulo, a R.A.E. como também nas mensagens enviadas pelo Presidente do Estado de São Paulo à Assembléia Legislativa e em toda a documentação oficial, memorandos, ofícios, processos em andamento de obras afetas à burocracia estadual e que ofereceram importantes subsídios para a pesquisa, assim como no levantamento bibliográfico específico, necessário para a contextualização dos reservatórios na realidade de São Paulo do começo do século $\mathrm{XX}$.

A cartografia, e outras fontes iconográficas, como plantas, croquis e desenhos, informações arquivísticas e bibliográficas foram importantes auxiliares para este estudo, contribuindo para uma melhor localização espacial e temporal dos lagos artificiais.

Aplicando-se o método progressivo, em uma primeira etapa, fez-se uma descrição da realidade presente, observando, ouvindo, levantando elementos, descrevendo, sem a preocupação ainda, com a análise das diversas temporalidades existentes e sobrepostas, ${ }^{56}$ o que permitiu o levantamento da situação atual dos reservatórios. Num segundo momento, aplicando-se o método regressivo, com os olhos do presente, volta-se ao passado para compreendê-lo, desvendá-lo, elucidálo. Esta fase, segundo CUSTÓDIO, $1990,{ }^{57}$ possibilita levar o diagnóstico um pouco mais longe, o que transforma esse método em um instrumento a mais de interpretação arqueológica e histórica dos reservatórios, e das mudanças que sofreram ao longo do tempo.

Em torno do objeto inicial vão-se assim criando linhas concêntricas do conhecimento e podemos iniciar a viagem no tempo, com cuidados e sem pressas, num caminhar que, regressivamente, nos vai possibilitando a visão dos diversos quadros da sua evolução. Esse caminho vai sendo acompanhado da pesquisa e estudo de documentos escritos, visuais, orais e tridimensionais - quanto maior for o leque de informações que sobre o objeto em análise pudermos recolher, tanto mais acurada poderá ser sua interpretação. ${ }^{58}$ (SANTOS e RIBEIRO, 1986)

\footnotetext{
${ }^{56}$ LEFÉBVRE, Henri. A Revolução Urbana. Ed. UFMG, Minas Gerais, 2004. LEFÉBVRE, Henri. O Direito à Cidade. Ed. Moraes, São Paulo, 1991.

${ }^{57}$ CUSTÓDIO, Jorge. Método Comparativo e Método Regressivo na Detecção do Moinho Gigante do Barão do Sobral, erigido no Barreiro. In I Encontro Nacional sobre o Patrimônio Industrial, vol II, Editora Coimbra Ltda., 1990, p.737.

${ }^{58}$ RIBEIRO, Isabel, SANTOS, Luísa. A Indústria do Papel na Perspectiva da Arqueologia Industrial. In I Encontro Nacional sobre o Patrimônio Industrial, Editora Coimbra Ltda, Coimbra, 1986, p.486.
} 
Aplicando-se o método comparativo, conseguiu-se analisar os paralelos tecnológicos das construções, possibilitando a compreensão das opções que levaram à sua escolha e a partir daí, a elucidação dos aspectos econômicos e históricos que envolveram sua implantação, ou seja, a sua contextualização na história econômica e social de São Paulo no início do século XX.

\subsection{São Paulo e o abastecimento de água no alvorecer do século XX}

"De um curso d'água nasce a vida e uma civilização. A água tem que ser domada, tratada e distribuída aos cidadãos" ${ }^{59} \mathrm{O}$ estudo da utilização da água para o consumo se reveste de fundamental importância para a memória das sociedades urbanas. O levantamento histórico-arqueológico da evolução dos sistemas de abastecimento de água constitui de certa forma uma abordagem dos aglomerados humanos que os conceberam e que deles se serviram. De sua análise, poderão ser inferidas ou confirmadas inúmeras relações de diversas ordens, sejam elas históricas, econômicas, sociais e outras. De patrimônio natural, a água adquire, através das várias formas da sua utilização, a qualidade de patrimônio histórico, envolvendo a memória dos sistemas tecnológicos desenvolvidos ao longo de todo o processo de sua conquista. Da abordagem dessas tecnologias se depreende uma correlação íntima com a evolução das sociedades, estando a água presente no urbanismo, na economia, na cultura e nas várias vertentes que compõem o todo social.

A São Paulo de Piratininga situava-se numa colina alta e plana, cercada pelos rios Tamanduateí e Anhangabaú, além do Pinheiros e Tietê, que corriam isolados e mais afastados do centro.

Apesar de se situar entre os rios, a cidade só utilizou as águas do Tietê para o abastecimento público por um breve período, quando as análises de potabilidade alertaram as autoridades para o fato de serem elas impróprias para o consumo. Foi necessário, então, recorrer-se a outras fontes, aos riachos e ribeirões na Serra da Cantareira, às "límpidas" nascentes cobertas de vegetação, o que levava as autoridades a se embrenharem cada vez mais pelo interior do Estado de São Paulo, à procura de "águas puras" capazes de servir à população paulistana.

\footnotetext{
${ }^{59}$ BIERRENBACH, Gastão César. In Curso d'Água. Publicação da Companhia de Saneamento Básico de São Paulo (SABESP), 1988, p.7.
} 
A sedentarização e o desenvolvimento urbano conduziram à procura de novos mananciais, ao recurso de tecnologias capazes de buscar água em lugares mais longínquos e em melhores condições de quantidade e qualidade, passando a técnica de mero processo de condução das águas aos complexos sistemas de domesticação e controle da natureza, com a correção de seus elementos, e cuja criação só foi possível com o desenvolvimento da ciência e de todo um saber acumulado por várias gerações.

Cada época teve o seu sistema que respondeu a um conjunto de necessidades do meio ambiente e social, interagiu com eles, proporcionando seu desenvolvimento o que, em breve, fez com que se esgotassem os recursos disponíveis, já que o processo dinâmico da busca por novas soluções está consubstanciada na história dos agentes que as conceberam.

São Paulo não é apenas o resultado do seu local, de sua situação e do seu clima: antes disso tudo, é o produto do trabalho dos homens que, em épocas diferentes, conforme as circunstâncias históricas mutáveis, tiraram partido da natureza inerte. Obra humana, a cidade e o seu crescimento são o reflexo e, ao mesmo tempo, o fruto das civilizações e das sociedades que se sucederam nas margens do Tietê durante quatro séculos. ${ }^{60}$

Cidadezinha de traçado colonial até meados de 1850, a acumulação do capital resultante da cafeicultura modificou-a em algumas décadas. Inaugurando símbolos de uma nova era, com a canalização das águas da Cantareira até o reservatório da Consolação para abastecer a cidade, a abertura de alamedas nos bairros dos Campos Elíseos ou de Higienópolis e a avenida Paulista, construída como um boulevard, mostraram, ainda na segunda metade do século XIX, a preocupação com a higiene e a influência estética francesa sobre seus novos trechos elegantes.

O final desse século representa uma grande guinada: "o vilarejo vira centro político, o aglomerado quase esquecido se transforma em ponto de referência", 61 com o esforço dos cafeicultores e dos governantes na tentativa de sanear a cidade e criar novos territórios da elite.

\footnotetext{
${ }^{60}$ MONBEIG, P. Aspectos geográficos do crescimento de São Paulo. In O Estado de São Paulo, SP, 25/01/1954, p.25.

${ }^{61}$ SCHWARCZ, Lilia Moritz, in Virando o Vinte. Secretaria do Estado .da Cultura, DEMA, São Paulo, 1994/1995, p.8.
} 
Começavam despontar os sinais do surgimento de uma grande metrópole, cujo complexo processo de urbanização exigiu o desenvolvimento de uma estrutura capaz de suprir as necessidades administrativas, comerciais, culturais, financeiras e materiais, os chamados serviços ou equipamentos coletivos urbanos, como o sistema de abastecimento de água e esgoto, fornecimento de energia, de alimentos, de área de ensino e saúde e todos os demais que pudessem acompanhar o desenvolvimento da sociedade paulistana em plena expansão.

Durante a última década do século XIX, em um momento de crédito facilitado pela República recém instalada e os altos índices inflacionários, o encilhamento, (nuvem de papel, para certos autores), inicia-se a industrialização como processo paulatinamente diversificado de produção mecanizada de bens de consumo imediato como alimentos, bebidas e tecidos. Essa produção é fortemente impulsionada pelo impedimento de importações decorrente da Primeira Guerra Mundial. ${ }^{62}$

Entende-se, portanto, o processo de urbanização paulistana como originário da própria expansão cafeeira, da abertura para a imigração, das aplicações financeiras no setor bancário e ferroviário que alimentavam o comércio e a indústria de São Paulo, posteriormente estimulada por uma crescente industrialização, o que ocasionaria profundas transformações que caracterizaram a cidade como distribuidora de mercadorias, capitais e força de trabalho para todo o Estado.

O rápido crescimento industrial, comercial, financeiro e, conseqüentemente, populacional de São Paulo começa a se manifestar em 1890. Nesta data, a cidade já tem perto de 65 mil habitantes e em 1900 chega a 239.820 mil.

O viajante Pierre Denis escrevia em 1900: "Saint-Paul est avec Rio le seul point du Brésil ou l'on puisse voir une foule". 63

Reformas urbanas urgentes eram necessárias para que a cidade pudesse ir ao encontro de seu destino de grande metrópole com modernizações feitas muitas vezes sob os auspícios dos cafeicultores paulistas que as sintonizavam com seus próprios interesses de exportação, ou simplesmente imobiliários, usando a intervenção governamental para atrair ou fixar investimentos de capitais internacionais para esses negócios.

62 SUZIGAN, Wilson et. Al. Crescimento industrial no Brasil: incentivos e desempenho recente, IPEA/INPES, Rio de Janeiro, 1974, p.128.

${ }^{63}$ DENIS, Pierre. Le Bresil au XX e siècle, 2.ed., Librairie A.Colin, Paris, 1928., p.112. 
Como notou Fernand Braudel, 1998, "uma cidade distinguir-se-á do campo circundante pelas funções que exerce, pelos equipamentos de que dispõe e pelos serviços públicos que oferece". 64

Em São Paulo, a urbanização acelerada exigia um aumento nas redes de serviços infra-estruturais como o abastecimento d'água, saneamento, coleta de lixo e outros, e a conseqüente necessidade de melhoria em sua distribuição sócioespacial, uso e aproveitamento.

A água sempre foi um elemento indispensável para a humanidade, e é assim desde os tempos mais remotos em que a presença do homem deixou testemunhos sobre a terra. Constitui um dos problemas econômicos intimamente ligados à vida financeira das cidades e fator fundamental para seu desenvolvimento; devido a sua enorme complexidade, seu correto planejamento depende de resoluções técnicas diferenciadas a cada caso.

Em 1890, a cidade de São Paulo começa a se desenvolver vertiginosamente e passa por crises periódicas, provocadas pela deficiência de um dos serviços públicos mais importantes, o fornecimento de água, que não acompanhava, pari e passu, seu crescimento e o aumento de sua população.

Nos primeiros anos da República, as crises se exacerbaram. Os serviços estavam deficientes e, em 1892, provocaram o clamor público contra a falta d'água. Esses serviços eram então explorados pela Companhia Cantareira, empresa privada, que detinha o monopólio da exploração do serviço de abastecimento de água, através de contratos celebrados com os poderes públicos.

Os melhoramentos no saneamento básico da capital paulista, deveriam ser de tal ordem que pudessem acompanhar o progresso e o povoamento da cidade. Com esse propósito, o governo chamando para si tal encargo, através do presidente do Estado de São Paulo, Bernardino de Campos, encampou a Companhia Cantareira de Águas e Esgotos e criou em 1893, através do decreto ํo 1524 de 31 de janeiro de 1893, a Repartição de Águas e Esgotos, (R.A.E.), dirigida até 1898 por José Pereira Rebouças, com novas propostas para solucionar o grave problema do abastecimento, no atendimento a uma cidade que, ao lado do aumento desordenado de sua população, enfrentava também períodos de estiagem prolongada, o que tornava a situação insustentável.

64 HENRIQUES, Luis Oliveira. Apud. A Iluminação a Gás da cidade de Leiria (1889-1904). In Arqueologia \& Indústria, Ed. Colibri, Lisboa, 1998, p.54. 
Nessa época, o abastecimento de água contava com apenas duas adutoras, a do Ipiranga e a da Cantareira. A primeira, com uma pequena represa na Água Funda, abastecia as zonas baixas próximas ao Tamanduateí, isto é, os bairros do Brás, Mooca e Ipiranga, e a segunda, com tanques de acumulação, fornecia água para o reservatório da Consolação, inaugurado em 1882, e que abastecia o centro da cidade.

Criada a R.A.E., foram ampliadas as instalações existentes para atender às necessidades da época, à medida que a cidade prosseguia num ritmo acelerado de progresso que, segundo se dizia, era somente comparável ao das grandes cidades norte-americanas.

Para atender a demanda da cidade em expansão, a Repartição criou várias comissões em diversos períodos, para encetarem a construção de obras novas quando se faziam mais urgentes e necessárias.

No final do século XIX, o problema do provimento de água à cidade era encarado sob três aspectos:

1. Captação de nascentes, feita de tal forma que a água não tivesse contacto com o ar desde sua origem até o sistema de distribuição em São Paulo; eram então consideradas as águas mais puras;

2. O projeto de aproveitamento de ribeirões, longe do centro da cidade, mas em cota superior;

3. O abastecimento por meio de rios, em especial pelo Tietê.

No primeiro caso, seria ideal o abastecimento de água de fonte captada subterraneamente e conduzida da mesma maneira para o consumo da cidade. Embora de difícil alcance, essas águas somente teriam sua qualidade atestada quando não houvesse população nas imediações das bacias hidrográficas, e quando as camadas superficiais de terra dessas bacias fossem de tal forma que garantissem um filtro natural infalível. Mesmo para a época, essas condições não eram fáceis de se encontrar e a literatura estrangeira registrava inúmeros casos de contaminação de águas nascentes; juntava-se a esses fatores o crescimento desordenado de São Paulo, espalhando-se pelos arredores constituindo-se em ameaça constante aos mananciais de águas mais puras.

O suprimento de água para a cidade provinha, com algumas exceções, da captação de pequenos ribeirões na serra da Cantareira, na colina, exclusivamente 
superficiais, carregando consigo todos os inconvenientes dessa origem, e sua inocuidade dependia essencialmente da superfície no entorno desses riachos.

Perseguia-se, entretanto, o mito das águas puras de cabeceiras vestidas de florestas, como determinava o Código Sanitário de 1894. As autoridades encarregadas do abastecimento, embora obrigadas a se contentar com águas de superfície, ao longo dos anos tiveram que buscá-las em fontes cada vez mais distantes, através de projetos de altos custos pela desapropriação de bacias inteiras para garantir a potabilidade da água e a construção de extensas linhas adutoras para seu transporte. ${ }^{65}$

De acordo com os relatórios da R.A.E., as águas das nascentes da serra da Cantareira foram escolhidas, porque, embora superficiais, eram consideradas de boa qualidade em razão de se localizarem em zonas pouco povoadas, cobertas de mata virgem, não havendo, segundo eles, possibilidade de contaminação do terreno, ainda que existisse um número considerável de germens, detectados nas análises da água, mas que de acordo com as autoridades, não representavam risco de transmissão de doenças para o homem.

Segundo MOTTA, $1911,{ }^{66}$ é infundado o preconceito contra as águas de fontes, pequenos regatos, córregos e ribeirões situados em regiões desertas e cuja protecção principal consiste em se fazer a expropriação completa das respectivas bacias, a fim de prevenir qualquer eventualidade de contaminação pelo ser humano.

Para essas águas não havia um sistema de filtragem completo, sendo assim, as chuvas fortes que lavavam e limpavam toda a superfície da bacia hidrográfica poderiam conduzir, através da água, todas as partículas soltas incluindo germens patogênicos.

\footnotetext{
${ }^{65}$ Foi o caso do aproveitamento do rio Claro, indicado, em 1905, por Saturnino de Brito como solução para o plano geral do abastecimento de água para a cidade de São Paulo. Com vários outros anteprojetos ao longo dos anos, teve seu início somente em 1926 e levou treze anos para ser construído.A captação e o tratamento do Sistema Rio Claro, são feitos a 80 k de São Paulo; através de uma extensa linha adutora de $77 \mathrm{~km}$, suas águas chegam ao reservatório da Mooca, com estações elevatórias auxiliares, reguladoras de vazão, e outras unidades que complementam o sistema. Muito criticada, e por várias vezes interrompida, foi uma obra considerada por muitos, como página obscura da engenharia do país, triste e infeliz aventura técnico-administrativa com malversão do dinheiro público, outros entretanto, reputava-na como uma das maiores obras de engenharia de sua época.

${ }^{65}$ Foram consultados os Relatórios da então Secretaria dos Negócios, Comércio e Obras Públicas do Estado de São Paulo de 1894 a 1904.

${ }^{66}$ MOTTA, Arthur. Estudos Preliminares para o Reforço do Abastecimento D'Agua da Cidade de São Paulo. Typographia Brazil-Rothschild \& Co. São Paulo, 1911, p.59.
} 
Nesse sentido, o Diretor, reiterava os procedimentos que deveriam ser tomados para o melhoramento das águas captadas: "deve-se proceder á limpeza da margem dos córregos, de modo a facilitar as inspeções freqüentes; extirpar todos os elementos vegetais que tenham invadido a orla de terreno abeira dos regatos; eliminar periodicamente as matérias de sedimentação nos leitos irregulares e pedregosos dos córregos; estabelecer drenos protetores contra as impurezas acarretadas pelas águas pluviais das estradas e vertentes e outras providencias que variam, com as condições locaes". ${ }^{67}$

Nesse mesmo período, a Repartição de Águas tentou, sem resultados satisfatórios, o aproveitamento das águas do subsolo, perfurando três poços profundos na margem do Tamanduateí, ao lado da ponte do Carmo.

Procedeu-se também à elevação das águas do rio Tietê (1898), captadas na altura do Belenzinho, para abastecimento das redes deste bairro, do Brás e da Mooca, a zona baixa, para onde a cidade começava a se estender nas primeiras décadas do século XX. Suas águas eram distribuídas depois de passadas por galerias filtrantes em época de crise dos mananciais, em razão de estiagens prolongadas que assolavam a cidade de quando em quando.

Quando rios atravessam núcleos populacionais, suas águas são utilizadas pelo homem. Sejam eles grandes ou pequenos, suas margens têm sempre merecido a preferência para o estabelecimento das populações. Aos poucos se desenvolveram em seu entorno aldeias, vilas cidades e capitais. Observou-se, porém, que, quanto mais densas tornavam-se essas populações, cada vez mais ficavam flageladas por doenças contagiosas tais como a cólera, o tifo, as enterites e outras, cujas epidemias mostravam intimidade entre a moléstia e a água como sua causadora.

Uma vez reconhecido o perigo, as cidades vizinhas aos rios procuravam, como alternativa, as águas de nascentes e poços. A bacteriologia, tirou as dúvidas sobre a etiologia dessas doenças contagiosas e a população que não tinha o recurso das fontes e de outras águas reputadas puras, lançaram mão das depurações das águas dos rios.

Em São Paulo, o primeiro momento de sua expansão territorial e de sua industrialização foi marcado pela orientação de políticos e engenheiros que

\footnotetext{
${ }^{67}$ Relatório da Repartição de Águas e Esgotos de São Paulo, de 1906, apresentado ao Secretario da Agricultura, pelo Diretor. São Paulo. Typographia Brazil de Rothschild \& Co., 1907, p.12.
} 
realizaram projetos específicos de correção de leitos e várzeas, trajetórias e reversões das águas doces urbanas, consideradas nesse período como sujas, destrutivas e verdadeiras ameaças à vida das populações ribeirinhas em época de enchentes. $^{68}$

Reputadas como um entrave ao progresso à incorporação e à conseqüente ocupação de importantes espaços da cidade, como também, um problema de salubridade, em razão da teoria miasmática, as várzeas e os charcos próximos aos rios eram encarados como locais de propagação de doenças, uma vez que em seu leito eram despejadas águas residuais sem nenhum tratamento, cuja ausência comprometia seu emprego no abastecimento à população, gerando grandes discussões entre as autoridades da medicina e da engenharia.

Em 1899, a R.A.E. concluiu a galeria do Belenzinho. Do conjunto dessa obra faziam parte: a casa das bombas elevatórias, o revestimento do poço, que conduzia à galeria filtrante, a conclusão da vala de filtração e admissão, obras de proteção contra as enchentes do rio, assentamento de duas bombas Warthington e respectiva ligação com a rede de distribuição que abasteceu a cidade somente no início de 1903, quando São Paulo enfrentava grave crise no abastecimento em função de uma das maiores secas de sua história. ${ }^{69}$

No relatório da Secretaria da Agricultura correspondente ao ano de 1899, o aumento na rede de distribuição e derivação de água e a construção de uma nova represa no ribeirão do Ipiranga tinham por objetivo melhorar o suprimento destinado aos bairros do Brás_e Belenzinho, que eram freqüentemente assolados pela interrupção do abastecimento.

O dr. Antonio Candido Rodrigues, secretário da Agricultura, relata a Rodrigues Alves, presidente do Estado, que "a galeria filtrante do Belenzinho, concluída o ano passado, não foi ainda em 1900 utilizada para o abastecimento da cidade baixa, visto não ter faltado agua dos mananciaes da Serra e do Ypiranga.

\footnotetext{
${ }^{68} 1890$ - Os Engenheiros Paula Sousa e Teodoro Sampaio realizaram estudos para retificar o leito primitivo do Rio Tamanduateí, transformando-o em um canal largo e profundo, para resolver problemas.

O córrego do Anhangabaú foi canalizado em 1906; sobre o rio canalizado, iniciou-se a construção das avenidas 9 de julho, para os lados do espigão central e no sentido da avenida Tiradentes, a da Luz, atual Prestes Maia, facilitando assim a ligação com a zona norte da cidade.

${ }^{69}$ Relatório da Secretaria dos Negócios da Agricultura, Comércio e Obras Públicas do Estado de São Paulo, de 1899, apresentado ao Presidente do Estado de São Paulo, pelo Secretário da Agricultura. Typographia do Diário Official, São Paulo, 1900, p.146/147.
} 
Todavia, esse recurso da água filtrada do Tieté, que será o abastecimento do futuro, se manterá e se melhorará para qualquer emergência difícil". ${ }^{70}$

Com relação ao ano de 1901, os relatórios da Secretaria da Agricultura ainda estudavam a possibilidade de se aproveitarem as águas do Tietê, o que, segundo eles, constituiriam um importante subsídio para o abastecimento da Capital "sem dispêndios quiçá superiores aos da própria renda do abastecimento e em todo caso dentro dos recursos ordinários do Thesouro". ${ }^{71}$

Este projeto do engenheiro Rebouças propunha a decantação das águas do rio por filtragem, utilizando-se os filtros rápidos americanos; entretanto, o debate era acirrado, uma vez que a escola de medicina acompanhava os índices de mortalidade dos bairros durante os surtos epidêmicos e o bairro do Brás era o mais afetado; alegavam que uma única análise das águas do rio havia sido feita por Artur Mendonça do Instituto Bacteriológico, que registrava sua impotabilidade, e, portanto, seu uso condenado ao consumo. A estiagem prolongada de 1903, que, segundo as autoridades, assumia proporções da seca do nordeste do Brasil, fez com que se retomasse o projeto de aproveitamento das águas do Tietê, cujas instalações ampliadas chegaram a fornecer $6.000 \mathrm{~m}^{3}$ por dia.

Entre 1905 e 1907 foi aduzida a primeira etapa do rio Cabuçu de Cima, com uma contribuição de $35.000 \mathrm{~m}^{3} / \mathrm{dia}$, quando eram diretores da R.A.E. Augusto Figueiredo e Arthur Motta e chefe da Comissão de Obras Novas Luiz Betim Paes Leme. Estas águas captadas em altitude de $750 \mathrm{~m}$ foram destinadas ao abastecimento das zonas baixas da cidade - Santana, Luz, Bom Retiro e Brás, circunscritas pela cota 735,000 , e a linha adutora construída para veicular 43.300 $\mathrm{m}^{3} /$ dia com $16.632 \mathrm{~m}$ de extensão foi inaugurada a $1^{\circ}$ de setembro de $1907 .^{72}$

Em 1911, a R.A.E. executou a segunda etapa, canalizando para esta adutora os recursos do vale do Barrocada, com $8.000 \mathrm{~m}^{3}$ de água por dia.

\footnotetext{
${ }^{70}$ Relatório da Secretaria dos Negócios da Agricultura, Comércio e Obras Públicas do Estado de São Paulo, de 1900, apresentado ao Presidente do Estado de São Paulo pelo Secretário da Agricultura. Typographia do Diário Official, São Paulo, 1901, p.219.

${ }^{71}$ Relatório da Secretaria dos Negócios da Agricultura, Comércio e Obras Públicas do Estado de São Paulo, de 1902, apresentado ao Presidente do Estado de São Paulo, pelo Secretário da Agricultura. Typographia do Diário Oficial, São Paulo, 1903, p.263.

${ }^{72} \mathrm{O}$ aproveitamento da bacia superior do Tietê foi objeto de estudos e fez parte de um relatório apresentado por Euclydes da Cunha, então engenheiro chefe do $2^{\circ}$ distrito de Obras Públicas do Estado de São Paulo (1896-1904), onde descreve o curso do rio, a constituição geológica de sua bacia, o esboço da rede hidrográfica composta por dois afluentes principais: os rios Paraitinga e Claro, que tão bem impressionaram o autor dos Sertões, que concluindo o relatório dizia: "dados estes esclarecimentos, resta-nos tratar da canalisação geral. Como indica a planta, ella terá um desenvolvimento maximo de 107 kilom. até São Paulo."
} 


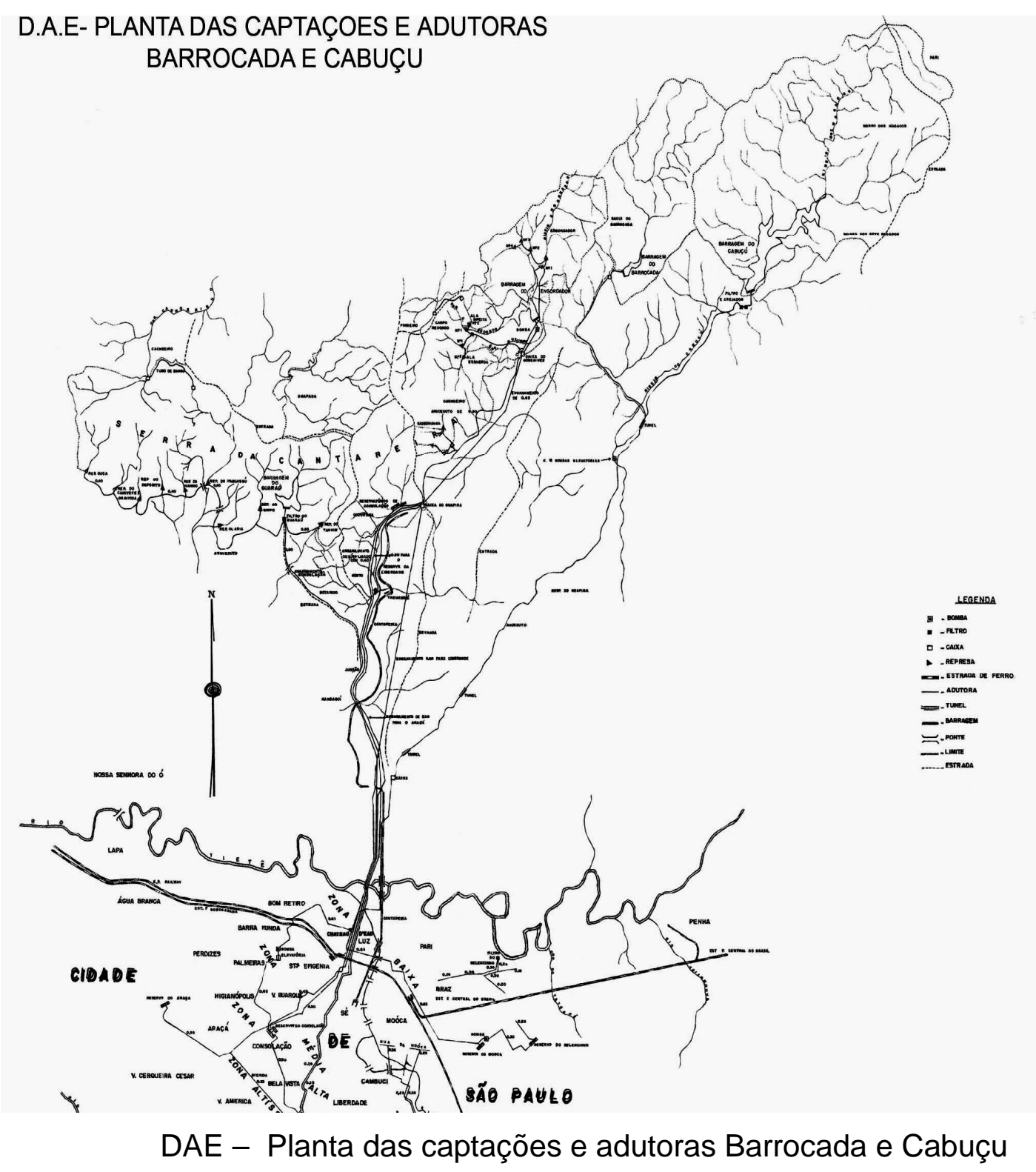

Com uma população de mais de 240.000 mil habitantes no início do século $X X$, intensificava-se a dinâmica da estruturação do espaço paulista, sob seus interrelacionamentos entre a industrialização e a urbanização que dividia ou, como querem muitos historiadores, segregava geograficamente os habitantes de acordo com suas classes sociais ${ }^{73}$, muito embora existam opiniões de que essa segregação espacial só viesse a se acelerar a partir de $1930 .{ }^{74}$

\footnotetext{
${ }^{73}$ BERTOLLI, Filho Claudio. A gripe Espanhola em São Paulo, 1918. Ed. Paz e Terra S/A, São Paulo, 2003, p.37.

${ }^{74}$ BONDUKI, Georges Nabil. Origens do problema da habitação popular em São Paulo, primeiros estudos. Espaço \& Debates, v.2, no 5, São Paulo, 1982, p.81-111.
} 
Outra corrente de pensamento, porém, atribui ao crescimento da cidade, desordenado, maior e mais rápido que o planejamento urbano, o motivo desencadeador do desequilíbrio entre a ocupação e a organização racional do espaço.

No final de 1893, a cidade de São Paulo sofre modificações importantes no que tange aos equipamentos coletivos e as autoridades resolvem dividir a cidade para efeito de abastecimento de água:

- ZONA ALTA: Liberdade, Glória Cambuci, Bela Vista, Consolação e Higienópolis a serem abastecidos pelo Reservatório da Liberdade em fase de construção.

- ZONA MÉdIA: Largos: Municipal e da Sé, Vila Buarque, Luz, Santa Efigênia, e Bom Retiro, Santa Cecília, Campo Elíseos, servidos pelo Reservatório da Consolação.

- ZONA BAIXA: Brás e Belenzinho com as águas dos tanques do Ipiranga e posteriormente com o Tietê.

Nesse período, como conseqüência direta da valorização territorial das áreas localizadas nas partes altas da cidade, surgem os arredores de São Paulo caracterizando-se como um mundo original, refratário a mudanças, começando a se transformar somente diante do impacto representado pela expansão urbana das mais significativas nos primeiros anos do século XX.

A população paulistana de baixa renda concentrava-se nas áreas vizinhas às várzeas, surgindo bairros como a Mooca, Bom Retiro, Brás, Belenzinho e Penha, com suas habitações coletivas, os cortiços, situados próximos às fábricas e as estradas de ferro.

"Era a cidade suja e infecta do operariado e dos marginais, dos imigrantes e dos negros, em tudo negação da urbe civilizada e higiênica progressista e esbelta". ${ }^{75}$

Nesta outra São Paulo, os equipamentos coletivos urbanos eram raros e de qualidade duvidosa, a exemplo do abastecimento de água que passou a utilizar o rio Tietê em 1903, e, conforme atestaram as análises efetuadas na virada do século, suas águas eram consideradas, em sua maioria, não potáveis, porque ,além de não receber nenhum tratamento, o rio ainda era depositário em seu curso de todo o esgoto da cidade sem qualquer tipo de desinfecção.

\footnotetext{
${ }^{75}$ CARLOS, Ana Fani. A cidade e a organização do espaço, apud BERTOLLI Filho Cláudio in A gripe Espanhola em São Paulo, 1918, Ed. Paz e Terra S/A, São Paulo, 2003, p.37.
} 
Captadas, como vimos, na altura do Belenzinho, estas águas foram aduzidas para as zonas baixas, na divisão altimétrica da cidade, passando por algumas galerias filtrantes, não só sem reservatórios, somente com caixa de distribuição, sem qualquer medida profilática, a despeito de seu estado sanitário deplorável na época das secas, em razão de o Tietê oferecer pouca profundidade, volume e correnteza necessários para a eliminação dos materiais tóxicos, como também, sem as desapropriações necessárias de seus mananciais e margens, para evitar o impacto antrópico causado sobre elas, uma vez que a população, muitas vezes, se dedicava à pecuária e à suinocultura fazendo do rio um grande depósito para os excrementos.

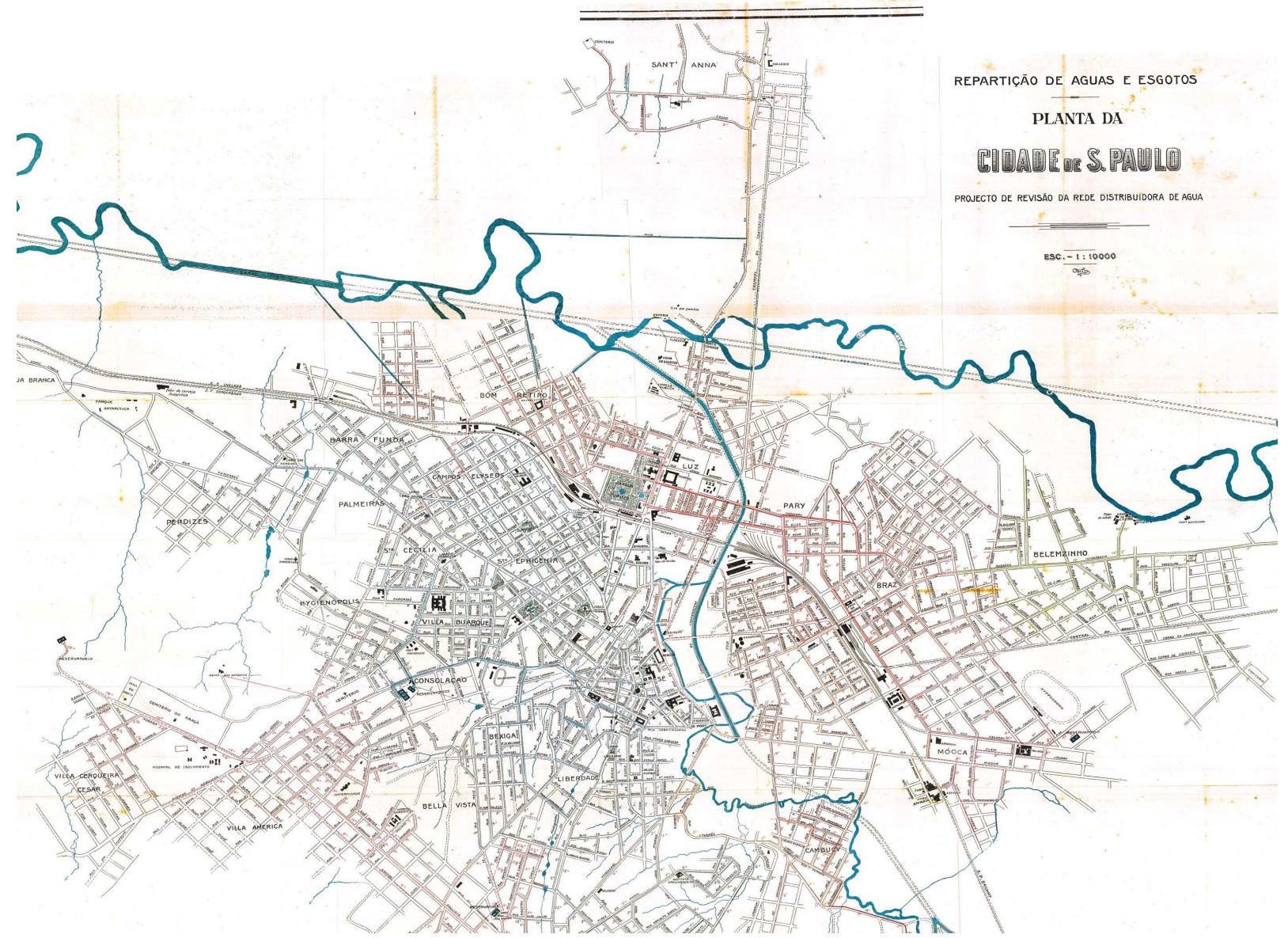

Mapa anexo ao relatório da Repartição de Águas e Esgotos de São Paulo (R.A.E.) de $1906^{76}$

A zona baixa, é "a marginal aos cursos de agua (Tieté e Tamanduatehy): nella habitam os proletarios, principalmente italianos, e de preferencia a industria ahi

\footnotetext{
${ }^{76}$ Relatório da Repartição de Águas e Esgotos de São Paulo, (R.A.E.), de 1906, apresentado, ao Secretário da Agricultura, pelo Diretor, Typographia Brazil de Rothschild \& Co., São Paulo, 1907.
} 
deve se estabelecer, podendo, portanto, supprir-se nos cursos proximos ou no lençol de agua da ampla várzea. Será a zona de maior amplitude, a mais populosa, por onde a cidade se desenvolverá sem limites". 77

Além das indústrias que se instalavam nas várzeas em finais do século XIX e começo do XX, era na margem esquerda do Tietê, a aproximadamente $200 \mathrm{~m}$ da avenida Tiradentes, que as carroças da limpeza pública descarregavam todo o lixo recolhido da cidade.

No local, a empresa particular responsável pelo serviço, a Deutsch e Dreyfus, mantinha ainda suas cocheiras, as oficinas para concertos de material, veículos diversos, vassouras e as habitações de empregados. Havia dois fornos incineradores, mas apenas um funcionava, admitindo uma pequena carga de lixo. Como não havia a incineração de um volume significativo, monturos formavam-se onde miseráveis e trapeiros catavam vidros, ferro, papel e trapos para sobreviverem. ${ }^{78}$ (RIBEIRO, 1993)

Houve uma grande reação por parte da Sociedade de Medicina e Cirurgia de São Paulo e da Escola Politécnica, que deu origem a um acirrado debate com a R.A.E., ligada à Secretaria da Agricultura, que havia preparado um projeto de utilização das águas do Tietê elaborado em 1904 pelo engenheiro Rebouças: "depurar as águas do Tieté por meio de sulfato de aluminio sem addição de cal, como já mencionamos, eleval-as á Penha e d'ahi distribuil-as por gravidade para uma parte da cidade". ${ }^{79}$, o que poderia representar um aumento substancioso ao fornecimento do precioso líquido à população.

O diretor da R.A.E., Dr. Arthur Motta, em seus "Estudos Preliminares para 0 Reforço do Abastecimento d'Agua da Cidade de S.Paulo", alegava serem as águas do Tietê livres de contaminação em razão de suas margens estarem quase desertas, e sua cabeceira, a montante de São Paulo, sem quaisquer pontos de degradação, comparadas com a dos rios Sena, Mississipi, Reno, Tamisa, Elba, Prata e outros que alimentavam centros populosos e que tinham suas águas contaminadas, ao longo de seus cursos, pelos dejetos das cidades ribeirinhas.

\footnotetext{
${ }^{77}$ Relatório da Secretaria dos Negócios da Agricultura, Comércio e Obras Publicas do Estado de São Paulo, de 1904, apresentado ao Presidente do Estado, pelo Secretario da Agricultura, Ed. Typographia Brazil de Carlos Gerke, São Paulo, 1905, p.224/225.

${ }^{78}$ RIBEIRO, M.A.Rosa. História Sem Fim, Inventário da Saúde Pública. São Paulo 1880-1930, Ed.UNESP., São Paulo, 1993.p.141.

${ }^{79}$ Revista Polytechnica. Escola Polytechnica de São Paulo, VIII Volume, Typographia Brazil, de Rothschild \& Co. São Paulo, 1913, p. 72-73.
} 
Partindo dessa premissa, esclarecia que:

O facto de se haver recorrido por alguns annos ás águas do Tieté, sem filtração ou qualquer outro tratamento aconselhável, para abastecer os bairros do Braz e Belemzinho, sem que adviessem consequencias funestas á população e sem qualquer prejuizo á salubridade publica, como attestam as estatística demographosanitarias. ${ }^{80}$ (MOTTA, 1911)

Porém, as suspeitas recaíam, inevitavelmente, sobre as águas do Tietê, porque, se observarmos as mesmas estatísticas, o Brás, comparando-se com outras áreas, apresentava o maior índice de mortalidade infantil entre 0 a 5 anos por problemas gastrointestinais como as enterites e enterocolites, além de ser o bairro onde se desenrolavam epidemias como a da febre tifóide.

Mortalidade proporcional, para menores de 5 anos, no Município de São Paulo e no Cemitério do Brás $\left(1893\right.$ - 1919) ${ }^{81}$

Tabela de índice de Mortalidade

ANO

1893

1894

1899

1905

1909

1911

1914

1917

1919

Média
Percentual de óbitos de menores de 5 anos

Município Cemitério do Brás*

$\%$

54,49

57,78

54,87

52,90

53,32

54,67
74,90

76,88

74,52

71,37

67,63

73,06

Doença típica de veiculação hídrica, surgindo de tempos em tempos, a febre tifóide tornou-se epidêmica na cidade de São Paulo, e, juntamente com as moléstias infecto-contagiosas, constituía-se em uma das principais causas de mortalidade. ${ }^{82}$

Quando começaram as obras de captação do Tietê, dois fatores importantes condenaram o projeto; em primeiro lugar, o local escolhido para a captação, a

\footnotetext{
${ }^{80}$ MOTTA, Arthur. Estudos Preliminares para o Reforço do Abastecimento D'Agua da Cidade de S.Paulo. Typographia Brazil-Rothschild \& Co., São Paulo, 1911, p.34.

${ }^{81}$ RAMOS, Reinaldo. Indicadores do Nível de Saúde no Município de São Paulo (1894-1959). São Paulo, 1962, Tese (doutorado) FSP/USP., P. 128.

${ }^{82}$ A febre tifóide somente foi debelada em São Paulo entre 1922 a 1927, com a cloração das águas do abastecimento.
} 
jusante do bairro da Penha, situava-se junto a uma poluidora fábrica de sabão. Em segundo lugar, rompeu-se uma galeria filtrante que não possuía as necessárias condições para este trabalho e que distribuía cerca de " 4 milhões de litros com 0 afanoso trabalho de seis bombas que, pelo ruído das engrenagens, dão a idéia do valor de uma instalação tão primitiva em uma cidade tão progressista". ${ }^{83}$, permitindo que a água contaminada chegasse a rede distribuidora domiciliar, no bairro do Braz, sem qualquer tratamento."

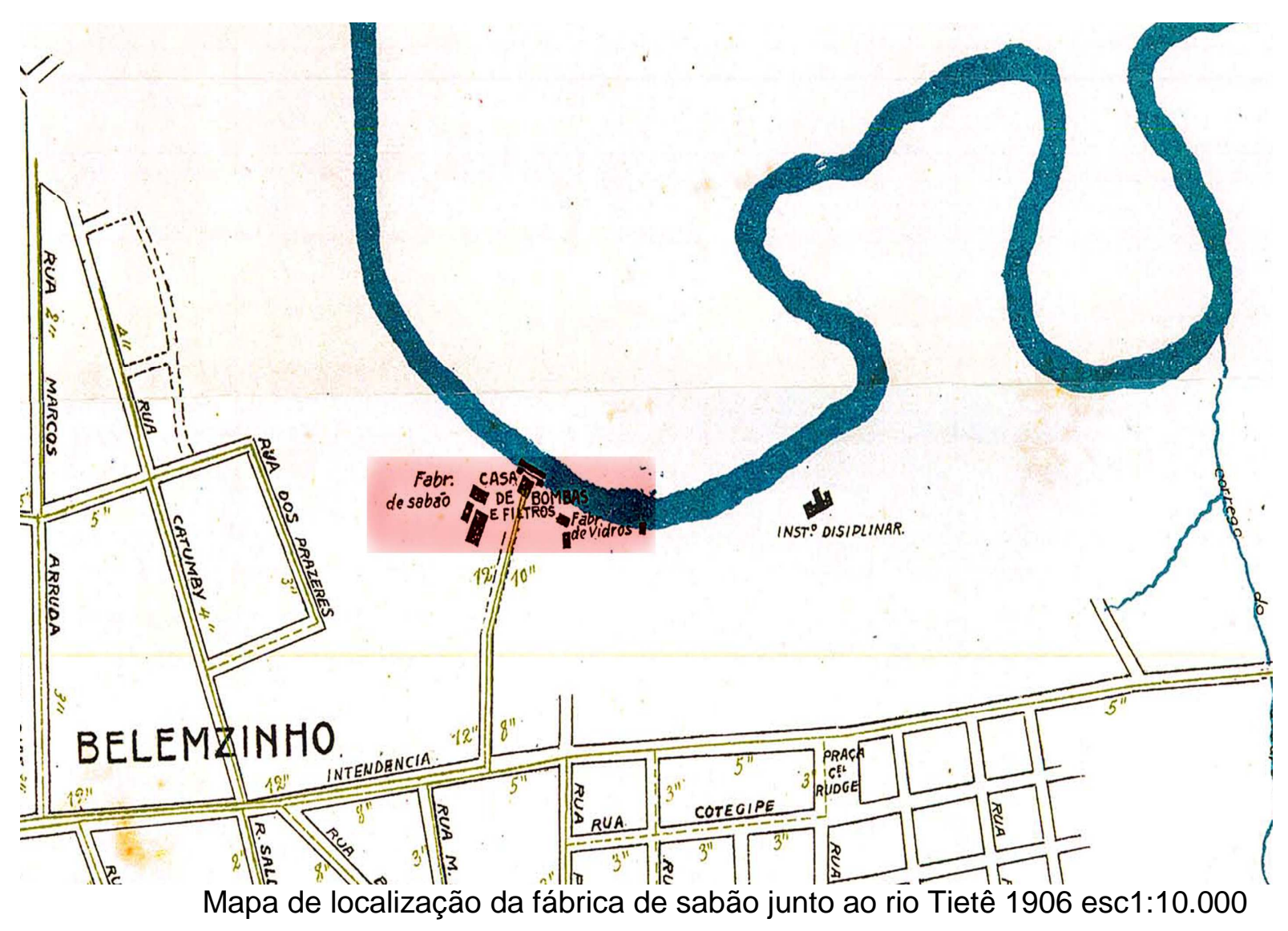

Em destaque, no retângulo em vermelho, a poluente fábrica de sabão junto às galerias filtrantes. Em azul o antigo leito do rio Tietê.

Segundo BRITO, 1943, tais fatos não colaboravam para que fosse maior a mortalidade do bairro baixo.

\footnotetext{
${ }^{83}$ BRITO, Saturnino de. Obras Completas de Saturnino de Brito, Vol III, Abastecimento de Águas. Parte Geral, Tecnologia e Estatística, Imprensa Nacional, Rio de Janeiro, 1943, p.58.
} 
Aquele em que se aglomera a população menos asseiada, em que as edificações são menos 'sanitárias' e em que o terreno, baixo e úmido, por si deveria concorrer para a depressão morbida na constituição médica regional. É que se colhe do que disse 0 eminente diretor do serviço Sanitário, o Snr. Dr. Emilio Ribas, sobre a salubridade do Braz e sobre o abastecimento pelo Tieté, convenientemente tratado“. ${ }^{84}$ (BRITO, 1943)

De acordo com BERTOLLI, 1995, coube ao senhor Saturnino transformar o rio em inimigo público: "lutar contra", "dominar", "domar", "impedir que o rio" e finalmente "vencer" o Tietê, expressões freqüentemente usadas pelo engenheiro sanitarista em relatórios e documentos que levam sua assinatura. ${ }^{85}$

A poluição do Tietê continuava sendo um motivo de preocupação para as autoridades, higienistas e paulistanos, e o grito de alerta foi dado pelo funcionário municipal José Joaquim de Freitas, encarregado da fiscalização dos rios da capital que assim se externava: “(...) no tempo da seca há no Tietê, em diversos pontos, grande ilhas de lodo que ficam a descoberto, em ativa fermentação. Vêem-se à superfície da lama pútrida bolhas que se levantam e rebentam, para escapamento de gases; ao sol quente estão em verdadeira efervescência. Essas ilhas vão crescendo e multiplicando-se. É a matéria dos esgotos que a corrente minguada na seca e quase sem velocidade não pode acarretar". 86

Um extenso e documentado memorial foi apresentado em 1903 ao Secretário Geral da Prefeitura de São Paulo, e, de acordo com o relato deste fiscal era urgente acabar com esses depósitos de lodo mal cheirosos cobertos de moscas e pernilongos que daí eram atirados para o centro da cidade ou para os diversos arrabaldes, conforme a direção dos ventos reinantes.

O engenheiro José Pereira Rebouças, apesar de todas as críticas, apresentou ao diretor da R.A.E., Teodoro Sampaio, em 3 de outubro de 1904, um projeto de elevação e distribuição das águas do Tietê, na importância total de $R \$$.5.243.730\$000, e uma planta geral desse projeto.

Em suas justificativas, alegava que a preferência ao recurso das águas do rio, tinha no tempo seu fator preponderante, sendo essa alternativa o meio mais

\footnotetext{
${ }^{84}$ BRITO, Francisco Saturnino de. Obras Completas de Saturnino de Brito. Vol III, Abastecimento de Águas. Parte Geral, Tecnologia e Estatística, Imprensa Nacional, Rio de Janeiro, 1943, p.58.

${ }^{85}$ BERTOLLI Filho, Cláudio. Cenas de embarque, In Tietê Mãe das Águas, Editora CJE/ECA/USP, São Paulo, 1995, p.51.

${ }^{86}$ Revista do Departamento de Águas e Esgotos de São Paulo, Ano XXXVI, no109, São Paulo, 1976, p.27.
} 
rápido de se resolver a grave crise do abastecimento que a cidade enfrentava, abandonando-se as propostas de adução por gravidade mais morosas e dispendiosas.

Propunha a captação do Tietê, a montante da Penha, por meio de uma torre situada no centro do rio, e a água seria conduzida à caixa de recepção, por uma galeria onde se operaria a primeira elevação para o tratamento. A depuração consistia no emprego de filtros rápidos nortes americanos (Jewel), com suas três fases: coagulação, ou precipitação química, sedimentação e filtração. O coagulante a ser empregado era o sulfato de alumínio, sem adição de cal. Depois de filtrada a água seria elevada para reservatórios descobertos a serem construídos no então morro do Cangaíba, na Penha, em cota $788 \mathrm{~m} 22$ a fim de reforçar a rede distribuidora da zona média tributária do reservatório da Consolação .

O destino do Tietê estava traçado: de um lado ficavam os partidários de sua utilização, pelo menos para o abastecimento das zonas média e baixa, com tratamento eficiente, através de filtragem rápida porque, segundo eles, eram notórias suas principais vantagens no que dizia respeito ao volume de água, passível de regularização e ao emprego de reduzidas estações elevatórias.

Não ignoravam a eficácia do tratamento das águas homens do governo e higienistas brasileiros como Carlos Botelho, Emílio Ribas, Theodoro Bayma, Paula Souza, José Pereira Rebouças, Teodoro Sampaio, Clemente Ferreira, Arnaldo Vieira de Carvalho e outros.

Do outro lado estavam o Arthur Motta, diretor da R.A.E. e prestigiadas autoridades médicas da época como Miranda de Azevedo, Monteiro Vianna e Rubião Meira que, enfaticamente, condenavam o tratamento químico das águas, principalmente no que dizia respeito ao emprego do sulfato de alumínio que, pela simples possibilidade de conter em sua composição química substâncias tóxicas, como o arsênico (arsenitos e arseniatos), deveria ser, "a priori", desprezado como coadjuvante na depuração das águas que seriam servidas à população paulistana.

Contra os filtros norte americanos, manifestaram-se os engenheiros Ataliba Valle, Fonseca Rodrigues e Victor Freire, partidários da filtração lenta e de experiências comparativas, a fim de se determinar, rigorosamente, qual seria 0 
tratamento acertado em razão da peculiaridade da composição química e bacteriológica do nosso Tietê. ${ }^{87}$

Muita polêmica gerou naquela época, o uso das águas purificadas dos rios, especialmente do Tietê, como poderoso auxiliar no abastecimento da cidade. $\mathrm{Na}$ opinião de muitos cientistas, seria muito mais seguro beber-se dessas águas depuradas do que as dos mananciais distribuídas sem o adequado tratamento, porque, embora viessem de bacias hidrográficas protegidas por desapropriações e pelo afastamento de habitações humanas, seriam facilmente contamináveis, segundo a Diretoria do Serviço Sanitário de São Paulo, pelos "portadores de germens", quer fossem eles guardas florestais, caçadores, animais domésticos ou selvagens. Além disso, o mesmo serviço constatou que, em épocas de chuva, as águas se turvavam, sinal de que a distribuição que deixava passar areia e terra também transportaria impurezas nocivas, embora não fossem percebidas a olho nu.

Perpetuava-se, entretanto, o mito das águas puras das fontes altas e integralmente abrigadas, o que, "de persi," garantiria sua potabilidade, sem necessidade de tratamento preventivo e purificador por eventuais contaminações. A esses fatores aliavam-se as condições sanitárias do rio Tietê cada vez mais comprometidas, bem como suas técnicas de purificação, que, além de pouco desenvolvidas e comprovadas, não tinham o aval, como vimos, das principais autoridades a quem estava afeto o problema do fornecimento de água à sedenta população paulistana.

Essas discussões caracterizaram "a retórica que dominava a engenharia de então". ${ }^{88}$ De acordo com os trabalhos dos professores da Escola Politécnica, Paula Souza, Roberto Mange e Hottinger, o problema do abastecimento de água seria solucionado com a contribuição do rio Tietê, rebatendo um estudo anterior do Diretor da R.A.E., Arthur Motta, que propunha a adução das águas do rio Cotia (1914) e a construção da represas da Graça (1916) e Pedro Beicht (1929), projetadas para

\footnotetext{
${ }^{87}$ De acordo com Vargas, em estreita relação com o problema de águas e esgotos estava a retificação do Tietê, cuja Comissão de Retificação, nomeada em 1927, pelo prefeito Pires do Rio revisou o estudo elaborado em 1924 por Saturnino de Brito, resultando daí um projeto integrado de retificação e urbanização, que estendeu a retificação até a jusante da grande curva de Osasco e a construção de cerca de 20 pontes. A retificação iniciou-se no final da década de 1930 continuando até os últimos meses de 1960.

VARGAS, Milton. Obras de Saneamento (Abastecimento de Água, Esgotos e Recuperação de Terras), In Tecnologia e Industrialização no Brasil, uma perspectiva histórica, Shozo Motoyama (organizador), Editora UNESP, São Paulo, 1994, p.100.

${ }^{88}$ VARGAS, Milton (organizador). História da Técnica e da Tecnologia no Brasil. Editora UNESP., São Paulo, 1994, p.197.
} 
regularizar sua vazão, o que para ele representava a solução mais acertada e que acabou vencedora.

Foi adotada também, depois de muitas paralisações e discussões, a adução do rio Claro, distante 80 quilômetros de São Paulo, obra complexa, com seus 70 quilômetros de linhas adutoras de tubos de aço, vários sifões, dois túneis e reservatórios em São Paulo.

Diante destes fatos, o aproveitamento do Tietê foi relegado e o rio abandonado à própria sorte, por existirem, segundo as autoridades, locais de captação de águas mais puras e cristalinas, menos expostas à contaminação e que poderiam ser represadas e aduzidas como era o caso dos ribeirões do Cabuçu, Engordador e Guaraú na Cantareira, que teriam uma contribuição valiosa na tentativa de minorar o sofrimento da população em sua luta constante para abastecer-se de água.

No final da primeira década do século XX, São Paulo tem uma população de 375.000 habitantes, distribuídos em um espaço urbano ainda carente de infraestrutura, como saneamento, transporte, vias e meios de comunicação, de circulação de mercadorias, obtenção e distribuição de energia e outros temas.

Para atender às necessidades imediatas do abastecimento de água da Capital, e, de acordo com o disposto nos artigos 28 e 30 da lei n. 936, de 17 de Agosto de 1904, foi criada a Comissão de Obras Novas de Saneamento e Abastecimento de Água da Capital, encarregada de estudos, projetos, orçamentos e execução das obras referentes a esse tão importante, quanto urgente ramo do serviço publico. ${ }^{89}$

Organizada essa repartição, chefiada pelo engenheiro Luiz Betim Paes Leme, procedeu-se imediatamente a novos estudos sobre o fornecimento de agua à cidade; cuidou-se, primeiramente, de fazer a estatística exata da rede de distribuição, de maneira a ser projetado um remanejamento que viesse eliminar os inconvenientes resultantes da divisão da cidade em zona alta, média e baixa, que não atendia às necessidades dos novos núcleos habitacionais que se formavam e cujo suprimento de água era deficiente, o que obrigava as autoridades a fazerem ramificações e derivações impróprias, invadindo zonas inferiores e causando graves perturbações, como perdas de água devidas às

\footnotetext{
${ }^{89}$ São Paulo, Leis e Decretos. Lei no 936 de 17 de agosto de 1904. Cria a Commissão de Obras Novas de Saneamento e Abastecimento de Água da Capital e dá outras providências.
} 
fortes pressões dos encanamentos; este conjunto de fatores animava os que adotavam o lema: "águas altas para as zonas altas; as águas baixas, especialmente as de rio, para a zona baixa". ${ }^{90}$

Desta maneira, foi projetada um nova distribuição das águas que estavam sendo captadas a fim de melhorar o que existia em relação ao serviço. A primeira idéia adotada foi a de que nenhum manancial deveria abastecer uma zona que ficasse em nível mais baixo daquele que pudesse ser abastecido pelo manancial imediatamente inferior.

Nesse intuito, a primitiva divisão do abastecimento foi modificada, ficando a cidade dividida em quatro zonas, segundo as altitudes provenientes dos mananciais captados e as de chegada aos reservatórios existentes e os que seriam construídos, e de acordo com a altura das zonas a serem servidas e a que viriam a ser abastecidas.

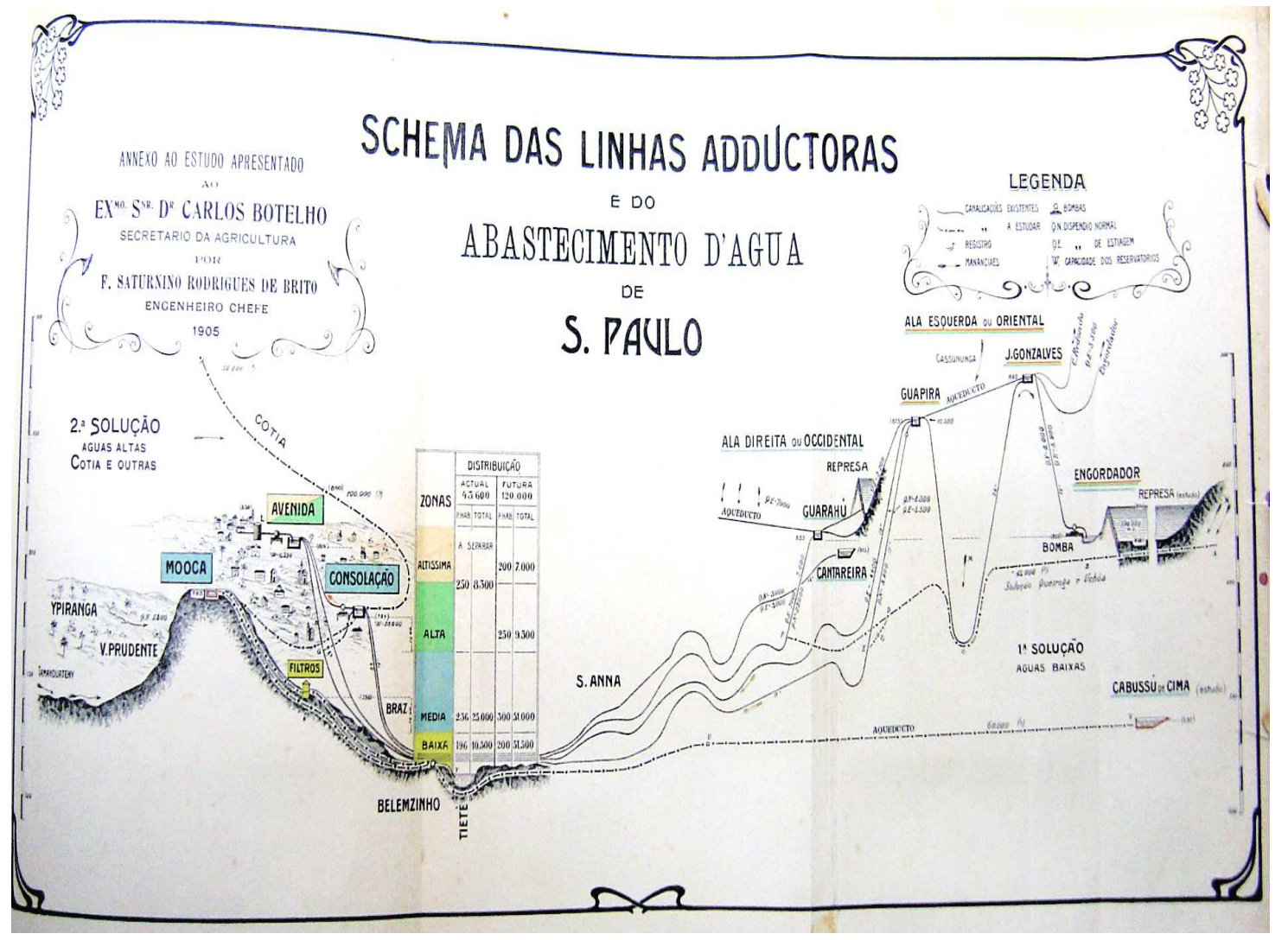

Esquema das linhas adutoras

\footnotetext{
${ }^{90}$ Relatório da Secretaria dos Negócios da Agricultura Comércio e Obras Públicas do Estado de São Paulo, de 1904, apresentado ao Presidente do Estado, pelo Secretario da Agricultrua.Typographia Brazil de Carlos Gerke, São Paulo, 1905, p 229.
} 
A figura acima encontra-se em anexo ao relatório da Secretaria da Agricultura de $1904 .^{91}$

- ZONA ALTíSSIMA: 800 metros para cima - consumo: 200 litros de água por habitante/dia e compreendia: os seguintes bairros:

- Vilas: Cerqueira Cesar, Mariana, Prudente e Clementino; Avenida Paulista, alto da Liberdade, alto do Ipiranga e alto de Perdizes que foram abastecidos por uma linha adutora que conduziria as águas da região do Engordador. A cota básica para o abastecimento desta zona era de 200 litros por habitante/dia.

- ZONA ALTA: entre 770 e 800 metros - consumo: 250 litros por habitante/dia, e era composta pelos bairros da Consolação, Bexiga, Liberdade, Vila Deodoro, Higienópolis e parte da Bela Vista, também servidos por uma linha adutora da também da região do Engordador, por intermédio de uma reservatório de acumulação existente na Liberdade.

- ZONA MÉDIA: entre 735 e 770 metros - consumo: 300 litros por habitante/dia. Abrangia os distritos de Santa Efigênia, Santa Cecília, Palmeiras, Campos Elíseos, Vila Buarque, alto da Barra Funda, Perdizes baixa, Água Branca, Lapa, Centro da Cidade, baixas da Liberdade, do Bexiga e da Glória.

- Esta zona foi tributária dos mananciais da região do Guaraú e do reservatório de Acumulação da Cantareira, através do reservatório da Consolação.

- ZONA BAIXA: 735 metros ou inferior - consumo: 200 litros por habitante/dia. Esta zona ficou assim constituída:

1. Contribuição do Cabuçu e Barrocada que estavam sendo captados e aduzidos aos bairros de Santana, Barra Funda (baixa), Bom Retiro, Luz, Pari, parte do Brás e da Moóca; para tanto foi construído um reservatório de compensação;

\footnotetext{
${ }^{91}$ Relatório da Secretaria da Agricultura, Comércio e Obras Públicas do Estado de São Paulo, de 1904, apresentado pelo Secretário ao Presidente do Estado. Typographia Brazil de Carlos Gerke, São Paulo, 1905, p.222.
} 
2. Tietê continuaria abastecendo o arrabalde do Belenzinho, porém filtrado;

3. Os mananciais do Ipiranga e as sobras dos andares superiores abasteceriam parte dos bairros do Cambuci e Brás.

Todas essas zonas foram ligadas umas às outras por meio de estações elevatórias, de forma a se socorrerem mutuamente em caso de ruptura nos encanamentos.

A distribuição das águas era feita diretamente pelo manancial, existindo um reservatório na extremidade da canalização que armazenava as sobras das águas durante as horas de pequeno consumo para reinjetá-las na rede durante os horários de pico, quando havia aumento da demanda. A alimentação da rede por suas duas extremidades tinha a grande vantagem de proprorcionar uniformidade de pressões nos encanamentos, o que diminuia o perigo de ruptura, permitindo uma redução sensível dos diâmetros das novas canalizações que, posteriormente, foram feitas com aumento considerável da capacidade das adutoras já existentes.

Foram então construídos três reservatórios com capacidade para armazenar 6.000 metros cúbicos de água: os do Araçá, para a zona altíssima, os do Brás da Móoca, que receberiam as águas do Cabuçu, e duas linhas adutoras de 25" ligando o chateau d'eau, situado na Luz, aos bairros do Brás, parte baixa do Bom Retiro, Barra Funda, Perdizes e outros. Todas essas zonas foram ligadas umas as outras por meio de estações elevatórias, de maneira a se socorrem mutuamente, em caso de ruptura nos encanamentos.

A segunda idéia adotada com relação ao abastecimento, foi que toda distribuição deveria ser feita diretamente pelo manancial, existindo um reservatório na extremidade da canalização para armazenar as águas em excesso durante as horas de pequeno consumo e reinjetá-las na rede durante as horas de consumo máximo.

Essa disposição de alimentar uma rede por suas duas extremidades, além da grande vantagem de estabelecer uniformidade das pressões no encanamento, diminuia muito o perigo de ruptura, permitindo uma redução sensível nos diâmetros das novas canalizações a serem estabelecidas e aumentando sensivelmente a capacidade das canalizações já existentes. 
A cidade de São Paulo, entretanto, nos primeiros anos do século $X X$, crescia em área e em população, e o desenvolvimento industrial aumentava consideravelmente o consumo de água. A administração pública, assumindo o encargo direto de prover este importante serviço, depois da encampação da Companhia Cantareira, procurou atender aos reclamos da população, então mal servida, principalmente depois da rigorosa estiagem de 1903. As zonas altimétricas que dividiam a cidade foram redefinidas e adotadas novas formas de captação da água, como a construção de represas, como a formação de lagos artificiais, na tentativa de por fim à grave crise do abastecimento, embora essa decisão tenha sido objeto de grandes polêmicas no Brasil e em todo o mundo, entre especialistas em abastecimento e qualidade de água.

\subsection{Lagos Artificiais - Algumas considerações}

A trajetória do homem foi sempre marcada por uma busca constante de locais onde houvesse abundância de água. Quando, porém, o precioso líquido começava escassear, sentiam necessidade de criar mecanismos que garantissem seu armazenamento de alguma forma e por um certo tempo, surgindo, assim, a construção de açudes com essa finalidade.

Antigas represas datam de um período histórico remoto; egípcios e etruscos já as utilizavam na alimentação hídrica de centros populosos e vestígios dessas primitivas construções foram também encontrados na Índia e no Sri Lanka, antigo Ceilão, na Itália, França, Bélgica, Inglaterra, Alemanha e Japão, países que também adotaram essas barragens no suprimento de água para suas cidades.

Constituem uma intervenção do homem na natureza com o objetivo de barrar um curso d'água, mantendo-o confinado e sob controle, adaptando seus padrões naturais às exigências do grupo populacional a que se destinam.

Bacias de grande extensão surgiam com o fechamento de um vale, e, a princípio, eram construídas barragens de terra para sua formação. Por volta do século XVI, no sudeste da Espanha, foi adotada a técnica dos muros de alvenaria, quando se construíram grandes reservatórios para irrigação, e em Madrid, esses recursos foram utilizados para o abastecimento de sua população. 
Mais recentemente, as barragens começaram a ser feitas com estrutura de alvenaria, pedra, madeira e concreto armado.

A maior vantagem obtida com grandes reservatórios para armazenamento de água, construídos para regularizar o fluxo de um rio com propósitos de irrigação, ou para o abastecimento de água doméstica, propiciou, a partir da segunda metade do século XIX, a realização de um considerável número de tais obras nas mais variadas partes do mundo.

Engenheiros franceses foram pioneiros na criação da primeira teoria racional de barragens e provaram sua assertiva aplicando-a na construção de alguns dos mais altos e arrojados reservatórios de muralha do presente.

Várias tentativas foram, então, surgindo, para o equacionamento de uma fórmula matemática adequada à construção dos reservatórios com muros de alvenaria, aperfeiçoando-se o método dos engenheiros franceses em vários aspectos, o que resultou numa importante conquista: a distribuição da pressão na inclinação das paredes da barragem. Os vários métodos propostos por esses técnicos forneceram apenas aproximações da fórmula teórica correta, até que o ideal pudesse ser atingido.

Muitas classificações podem ser esboçadas em se tratando de águas potáveis. Intervêm critérios múltiplos, segundo as variantes de qualidade, a procedencia geológica, os caracteres distintivos de natureza geográfica ou topográfica. Tomando-se, porém, o aspecto literal e menos complexo, e de acordo com a feição hidráulica, existe uma antiga divisão feita por Belgrand ${ }^{92}$ engenheiro e geólogo francês, de águas correntes, dormentes e subterrâneas.

a) Correntes: 1 -grandes cursos - regime tranqüilo e regime torrencial 2 - pequenos cursos - a mesma subdivisão

b) Dormentes: 1 - lagos naturais - grandes massas e profundas

- pequenas massas de pouca espessura

2 - lagos artificiais - a mesma subdivisão

\footnotetext{
${ }^{92}$ BELGRAND, Eugène. Auxiliar de Haussman, estudioso de bacias hidrográficas e qualidade das águas, construiu entre outras obras o reservatório de Montsouris, de $156 \mathrm{k}$ de comprimento, o maior de Paris e uma dupla rede de canalizações subterrâneas em alvenaria, de grandes dimensões, por onde passam as tubulações das águas potáveis e servidas, os famosos esgotos de Paris.
} 
c) Subterrâneas: 1- lençol profundo

2 - lençol freático

3 - fontes: - jorrantes

- vertentes

- emergentes ${ }^{93}$

"Todas as águas que bebe a população de São Paulo, são águas de superfície, serão de três tipos que enumeraremos pela sua ordem de qualidade:

1- Água de lagos artificiais;

2- “ " "pequenos córregos de cabeceiras desapropriadas;

3- " do Tieté $\left(^{*}\right)$

Essa classificação é do engenheiro americano Fuertes, segundo dizem os distinctos engenheiros Drs. Ataliba Valle e Fonseca Rodrigues, n'um interessante opusculo sobre o abastecimento d'agua de S.Paulo". ${ }^{94}$

A maior controvérsia entre ambientalistas, sociólogos, engenheiros e outros estudiosos do assunto e que, até hoje, gera polêmica diz respeito à criação de lagos artificiais que, dentre vários inconvenientes, apontam as alterações do clima, o agravamento de doenças transmitidas pela água, a modificação das condições ecológicas das espécies aquáticas, da fauna e flora terrestres em regiões vizinhas, erosões e assoreamentos do leito dos rios e dos próprios lagos e outros.

Entretanto, meio eficaz de regularizar o consumo durante longas estiagens, as represas constituem-se em valioso instrumento para a indústria, como força motriz, para a irrigação das lavouras e abastecimento das cidades, regularizando a demanda especialmente nas regiões assoladas pelas secas.

A esse respeito um famoso médico e engenheiro, diretor do serviço municipal de Nancy, França, Dr. Ed. Imbeaux, dizia:

\footnotetext{
${ }^{93}$ Brasil, Leis e Decretos. Resolução CONAMA no 20, de 18 de junho de 1986. Estabelece uma classificação de águas doces, salobras e salinas do Território Nacional.

${ }^{94}$ Relatório da Secretaria dos Negócios da Agricultura, Comércio e Obras Públicas do Estado de São Paulo, de 1906, apresentado ao Presidente do Estado pelo Secretário da Agricultura. Typographia Brazil de Rothschild \& Co., São Paulo, 1907, p.306.
} 
La création de lacs artificiels par les barrages reservoirs est donc non seulement um procede d'emmagasinement, mais encore de clarification: aussi en a t'on installé, spécialement em vue de ce second but, comme par exemple le bassin de St.Christophe pour décanter les eaux de la Durance destinées à l'alimentation de Marseille. ${ }^{95}$ (IMBEAUX, 1902)

Corroborando com essa opinião, estavam também autoridades no assunto como Georges Bechmann, chefe dos serviços técnicos do saneamento de Paris e professor da Escola de Pontes e Calçadas, o engenheiro sanitarista Alphonse .A. Debauve, James H. Fuertes, professor de Engenharia Sanitária da Universidade de Cornell e especialista em trabalhos de filtragem da água, além das conclusões favoráveis de inúmeros especialistas e as recomendações adotadas pelo Congresso Alemão de Treves, em 1900.

Considerados por muitos como excelente recurso para alimentar as cidades com água, em caso de falharem as fontes naturais, e dominar a escassez de águas correntes, esses lagos são criados por meio de barragens ou diques que cortam um vale em um ponto conveniente ao represamento de rios e córregos, com o fim de se formarem reservas destinadas a suprir a rede de distribuição nos tempos de estiagem, garantindo a capacidade efetiva das linhas adutoras no transporte da água a seu lugar de destino.

A comissão de Obras Novas, recém criada, (1904), tinha como plano emergencial na solução do grave problema do abastecimento de água à cidade de São Paulo a construção de três lagos artificiais: Engordador, Guaraú e Cabuçu; porém, tratava-se de problema de difícil solução, em razão de pareceres contraditórios ao projeto, como um novo gênero de captação, por serem suas águas paradas propícias à propagação da febre tifóide e do cólera, que dizimavam centenas de pessoas na Europa e nos Estados Unidos.

Segundo o Código Sanitário, ${ }^{96}$ a água destinada à população, sempre que possível, deveria provir de mananciais situados na serra, argumento usado pelos críticos do projeto da Comissão, que desconsiderando seus argumentos e fazendo

\footnotetext{
${ }^{95}$ IMBEAUX, Édouard Debauve A. L'alimentation en eau et assainissement des villes. Editora Bernard, Paris, 2 v, 1902, v. 1, p.134.

${ }^{96}$ São Paulo Leis e Decretos. Decreto no 233 de 2 de Março de 1894. O Presidente do Estado, para a execução do artigo 3ํㅡㄹ da Lei oㅡ 240 de 4 de Setembro de 1893, estabelece o Código Sanitário.

Artigo 311. A água destinada aos usos domésticos deverá ser potável e inteiramente insuspeita de polluição.

Artigo 312. Provirá de manancial sempre que fôr possível com origem em serra.
} 
prevalecer as opiniões favoráveis, inicia a construção das barragens, formadoras dos lagos artificiais, como medida eficaz para se formarem novas reservas destinadas a suprir a rede de distribuição em épocas de estiagem, garantindo assim a capacidade efetiva das linhas adutoras.

A polêmica sobre as águas armazenadas atravessou décadas como se pode depreender da enquete promovida pelo "Diário da Noite" de janeiro de $1928^{97}$,: "Podemos contar com águas armazenadas para solucionar o grave problema do abastecimento de água na cidade de São Paulo" nela, o Diretor da R.A.E. e demais autoridades especialistas no abastecimento de água, emitiram suas opiniões:

Arthur Motta:

Sim, devemos contar com o armazenamento das águas no período das precipitações meteóricas abundantes, para restituir as reservas durante as estiagens, sendo variável a cada caso particular, a relação que deve existir entre o volume mínimo observado e a vazão diária. ${ }^{98}$ (MOTTA, 1928)

Rebatendo essa opinião, João Pereira Ferraz :

A meu ver, de águas armazenadas não devemos lançar mão, pois que taes aguas, muito sujeitas a contaminação e polluidas com a mor facilidade não é possivel contar, com ellas como "agua potavel" unica a fornecer á população com plena confiança.Quanto ao volume ou quantidade, o calculo de relação não offerece difficuldade alguma, dado o volume minimo observado e a vasão diaria. ${ }^{99}$ (FERRAZ, 1928)

\footnotetext{
${ }^{97}$ In Revista Viação. Revista Technica, Mensal, Illustrada. Vol.d. Número Especial, Rio de Janeiro, 1928, pp 18 e seguintes.

${ }^{98}$ Engenheiro Diretor da Repartição de Águas e Esgotos de 1906 a 1936.Sua opinião, entretanto não era a mesma no começo de sua gestão quando se mostrou favorável a adoção dos lagos artificiais como auxiliar no abastecimento de água à cidade de São Paulo.

${ }^{99}$ Engenheiro dirigente da Comissão de Saneamento do Estado de São Paulo e a partir de 1893, professor da Escola Politécnica de São Paulo, primeiro catedrático da cadeira de hidráulica e saneamento.
} 
Plínio de Queiroz:

Não. Não devemos contar com aguas armazenadas, isso porque inumeras razões que seria fastidioso enumerar; limito-me a lembrar a irregularidade na distribuição de nossas chuvas, a "ignorancia completa" que temos sobre o regime de nossas bacias, a impropriedade dessa solução entre nós devido ás condições climatericas e geologicas que concorrem para perturbar as qualidades das aguas armazenadas, tal como tem acontecido na barragem do Cabuçu, no Engordador ${ }^{100}$ e outras". ${ }^{101}$ (QUEIROZ, 1928)

\section{Paulo Moraes Barros era de opinião de que em princípio não se deveria utilizar essas águas.}

Uma vez que contamos com aguas correntes em volume sufficiente. Só o estudo demorado dos regimens fluviaes e as observações ainda mais demoradas sobre as precipitações athmosphericas nas bacias hydrographicas em questão poderão servir de base a qualquer calculo para estabelecer a relação da vasão normal com a da accumulação e distribuição compensadora ". ${ }^{102}$ (BARROS, 1928)

\section{Egydio Martins era favorável ao uso desse recurso:}

Sendo a decantação lenta um processo natural de melhoria das aguas desde que sejam feitas as necessarias descargas regulares pelo fundo da bacia decantadora na época das sobras, não vejo razões para condemnar-se este excellente recurso. Por isso tambem não me parece de bom aviso, armazenarem-se uzurariamente todos os recursos ficando-se sem sobras suficientes para as descargas indispensaveis. As bacias bem conservadas e saneadas com descargas regulares devem ser aconselhadas para o aproveitamento das linhas existentes e, se condemnarmos irreflectidamente as barragens, collocaremos as adductoras de Cotia, Cabuçu e Cantareira em tal situação de penuria, que nos forçará a lastimar tanto gasto para adduzir tão pouca agua. ${ }^{103}$ (MARTINS, 1928)

\footnotetext{
${ }^{100}$ Grifos nossos.

${ }^{101}$ Engenheiro formado pela Escola Politécnica de São Paulo, e criador da Revista Politécnica, trabalhou durante muitos anos na Repartição de Águas e Esgotos de São Paulo, e foi membro efetivo do Conselho Consultivo de Águas e Esgotos de São Paulo até sua morte em 1971.

${ }^{102}$ Médico, formado pela Faculdade de Medicina do Rio de Janeiro, foi secretário de Agricultura, Indústria e Comércio de São Paulo de 1912-1915, em 1930 ocupou o Ministério da Aviação e Obras Públicas, e posteriormente em 1932, foi secretario da Fazenda do governo de Pedro de Toledo.

${ }^{103}$ Engenheiro que fez parte da comissão de técnicos, formada entre outros por Ramos de Azevedo e Theodoro Ramos, nomeada pelo presidente do Estado de São Paulo, Júlio Prestes, em setembro de 1927 para avaliar as obras de captação do rio Claro. Sua conclusão foi a de que a adução de suas águas de longa distância (80 k.), implicava preços exorbitantes: 150 mil contos, enquanto que os
} 
Bruno Simões Magro considerava que "seria conveniente aproveitar as aguas armazenadas pelas empresas que exploram a força hydro-electrica, dependendo de estudos a gosto de sua contribuição". ${ }^{104}$

As grandes barragens, sabe-se, constituem o precioso recurso regularizador do consumo de estiagem, onde se não tenham águas perenes ou de fácil aprovisionamento, tanto para o uso industrial (força hidráulica, alimentação de caldeiras, etc;) como para a alimentação das cidades e para irrigação das terras". ${ }^{105}$ (BRITO, 1928)

custos da adoção dos rios Tietê-Pinheiros seriam de 70 mil, portanto, de solução mais fácil e econômica; sob o aspecto da salubridade, concluiu a comissão que a perfeição que atingiu o tratamento químico das águas naqueles últimos anos representava uma garantia para a salubridade pública, e portanto, deveriam ser abandonados os projetos de captação de águas de fontes altas e protegidas quando distantes e a preços tão exorbitantes.

${ }^{104}$ Engenheiro-arquiteto, professor da Escola Politécnica e da Faculdade de Arquitetura e Urbanismo, autor de projetos importantes como o da Igreja Nossa Senhora do Brasil e da Catedral Evangélica de São Paulo e das modificações feitas no projeto original da então "Estação Sorocabana", hoje Júlio Prestes, que abriga a Sala São Paulo. As mudanças causaram indignação ao autor da planta original, o arquiteto Cristiano Stockler das Neves, que moveu um processo judicial contra a Sorocabana que foi defendida por Bruno Simões Magro, que alegava serem as mudanças transitórias e movidas por problemas administrativos e financeiros.

${ }^{105}$ BRITO, Saturnino de. Obras Completas de Saturnino de Brito, Vol III, Abastecimento de Águas, Ed. Imprensa Nacional, Rio de Janeiro, 1943, p.67. 


\subsection{As barragens da Cantareira}

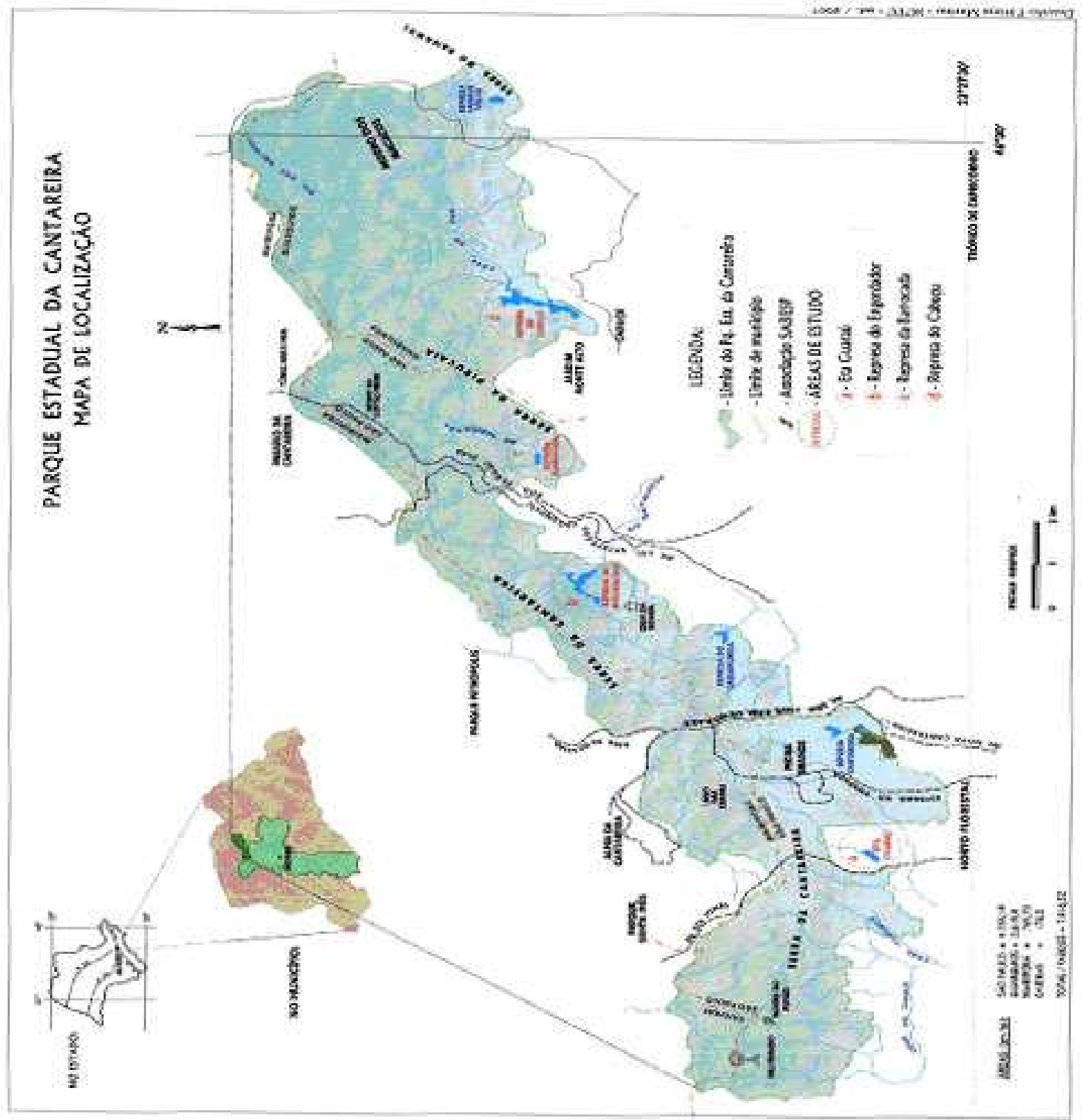

Mapa de localização do Parque Estadual da Cantareira

Foi dividido em duas partes distintas o projeto da Comissão de Obras Novas, em 1904, para tentar resolver o calamitoso problema de dessedentar a população paulistana: a primeira consistia em completar a capacidade dos encanamentos que vinham da Serra da Cantareira em direção aos dois reservatórios centrais, o da Consolação e o da Avenida, fazendo-os trabalhar, em períodos de estiagem, com volume de água igual ao dos meses de chuva. 
Foram construídas as barragens do Engordador e Guaraú, na Serra da Cantareira, criando lagos artificiais de acumulação que enviariam suas águas aos dois reservatórios, da Avenida e Consolação, como tentativa de minimizar o grave problema do abastecimento.

Os técnicos da R.A.E. acreditavam que, com o aumento no volume de água que os dois reservatórios forneceriam, estaria resolvida a primeira etapa e, desta maneira, poderiam passar para a segunda fase, ou seja,direcionar os estudos para resolver de maneira definitiva o problema da água, fazendo cessar o justo clamor público pela sua falta, com o projeto de construção da terceira barragem, a do Cabuçu, com a adução das águas dos ribeirões Cabuçu e Barrocada. 


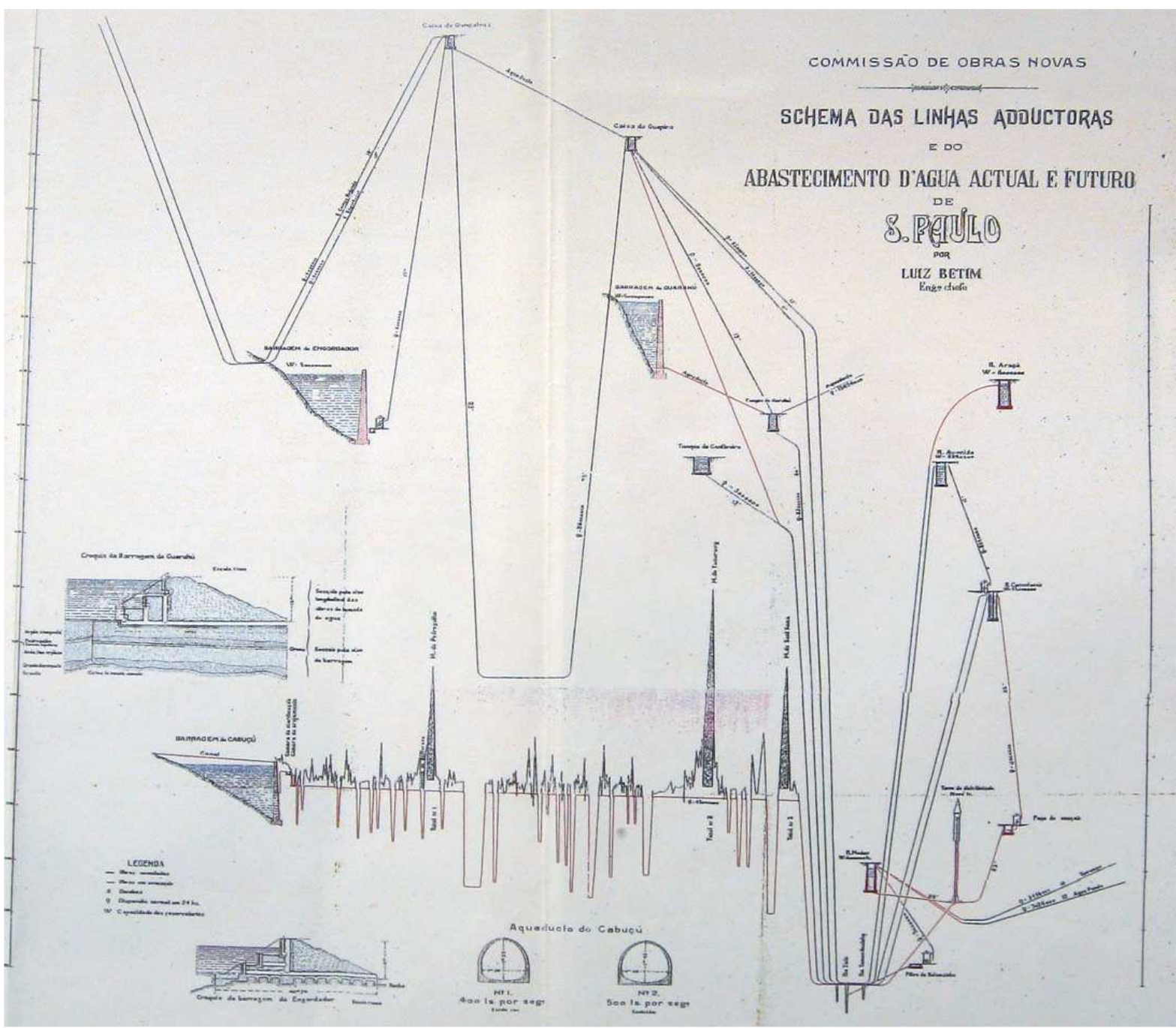

Esquema das Linhas Adductoras da Comissão de Obras Novas e do Abastecimento D’Água Actual, e Futuro de São Paulo, por Luiz Betim Eng ${ }^{\circ}$ chefe. ${ }^{106}$

Enquanto se projetava a construção destes três lagos artificiais, do Engordador, Guaraú e Cabuçu, seus opositores apontavam também as desvantagens do empreendimento: muito dispendioso e de resultados duvidosos, principalmente. em climas tropicais como o nosso, que poderiam causar graves perturbações na potabilidade da água que, armazenada, apodrecia, necessitando, naquela época, para se tornar de qualidade, de tratamentos químicos e bacteriológicos bem mais complexos que a simples passagem por filtros de areia.

O Diretor da Repartição de Água e Esgotos de São Paulo, Arthur Motta, em 1906, desaconselhava a construção das barragens para formação de lagos artificiais como forma de aumentar os recursos de uma cidade situada em zona tropical e que

\footnotetext{
${ }^{106}$ Relatório da Secretaria dos Negocios da Agricultura, Comercio e Obras Publicas do Estado de São Paulo, de 1905, apresentado ao Presidente do Estado, pelo Secretario da Agricultura.Typographia Brasil de Rothschild \& Co., São Paulo, 1906, p.227.
} 
dispusesse de bacias hidrográficas em volume satisfatório para atender as necessidades da população. Além disso, para viabilizar esses projetos era mister que se fizessem estudos detalhados e pormenorizados dos cursos d'água, dos lagos, dos respectivos regimes e da meteorologia local, estudos esses que exigiam tempo, paciência e muito trabalho.

Alertava também para a decomposição das matérias orgânicas que existem na superfície da terra e que são arrastadas pelas fortes chuvas e enxurradas trazendo, em conseqüência, a proliferação de micro organismos, principalmente das algas, resultantes dos fenômenos da estagnação, "da água parada" nesses lagos, e, por essa razão, as alterações de seus caracteres organolépticos eram provenientes de várias e complexas circunstâncias que colocavam em xeque as condições do abastecimento, a quantidade versus a qualidade do líquido a ser consumido pelos habitantes de uma região.

Expressava sua preocupação com nosso clima, umidade, hidrologia, fauna e flora que sujeitavam as águas à fermentação e à proliferação de fenômenos de intensidade variável e cuja remoção, química e bacteriológica era, muitas vezes, difícil de se conseguir.

O engenheiro Paes Leme, encabeçando a Comissão de Obras Novas, entretanto, ao optar pela solução de abastecer a cidade com lagos artificiais, deixou de lado as críticas restritivas ao seu uso e respaldou-se na opinião favorável de renomados especialistas em abastecimento de água e na experiência adotada, como já dissemos, em países como Estados Unidos, Inglaterra, Itália, França, Japão, Espanha, Austrália e Índia.

A escolha do tipo das barragens é, em geral, determinada pela natureza do solo e dos materiais de construção encontrados nas proximidades da obra; podem, portanto, ser feitas de terra, alvenaria, mistas, enrocamento, madeira e concreto armado, as de alvenaria devem ser assentadas sobre um solo impermeável e incompressível, aquele em que, embora submetido à forte pressão, não diminui, continua inalterado. Já dizia De Mas, em 1904, “(...) on doit reconnaitre qu’il est indispensable de disposer, pour l'assiette des barrages en maçonnerie, de terrains absolument compacts et resistentes." 107

\footnotetext{
${ }^{107}$ MAS, François Barlatier. Canaux. Encyclopedie des Travaux Publics. Ed.Beranger, Paris, 1904, p.118.
} 
As barragens de terra, quer do tipo francês de massa homogênea, mescla de argila, areia e cal, quer do tipo inglês, mistura de diferentes materiais, podem ter sua fundação sobre um solo compressível, exigindo-se apenas para sua garantia a condição de impermeabilidade.

À necessidade de construção imitando o systema inglês para
execução barragens de terra, bastando abrir axialmente uma vala
para receber o núcleo de material socado e apropriado a impedir as
infiltrações pela base; este impedimento teria apenas por fim evitar
que a água se escapasse por filetes prejudiciais, e não a humidade
proveitosa às preciosas vazantes de açude. ${ }^{108}$ (BRITO, 1943)

As três barragens, construídas pela comissão de Obras Novas, nos vales dos rios Engordador, Guaraú e Cabuçu, juntamente com os reservatórios de acumulação da Cantareira, formavam o Sistema Cantareira Antigo. Para a construção das duas primeiras, entre o sistema francês e o inglês, aquele foi adotado, porque de acordo com as considerações de Arthur Motta, diretor da R.A.E., em 1905:

Satisfaz o princípio universalmente aceito, hoje - da homogeneidade do material de construcção, principio que se traduz por uma grande garantia contra os recalques desiguaes. Alem disso não se devem admittir no typo inglez, orificios de escoamentos no corpo da barragem, o que é permittido no typo francez desde que seja tomadas serias precauções. ${ }^{109}$ (MOTTA, 1905)

Para o Cabuçu, o material escolhido foi o concreto armado, que no final do século XIX e começo do XX, revolucionou a técnica construtiva com uma série de vantagens em relação a outros materiais, principalmente no que dizia respeito às estruturas das barragens que exigiam um grau de segurança que as pusesse ao abrigo das rupturas pela força da água.

Nos relatórios da Secretaria da Agricultura de 1904 a 1906 estão descritas as sondagens feitas nos vales do Engordador e Guaraú que detectaram a má qualidade dos terrenos para a fundação. No primeiro caso, os técnicos constataram a existência de grandes blocos soltos, justapostos ou mergulhados no terreno sedimentário, obrigando-os a descer cerca de nove metros abaixo do fundo do vale,

\footnotetext{
${ }^{108}$ BRITO, Saturnino de. Obras Completas de Saturnino de Brito, Vol. III: Abastecimento de Água, Parte Geral, Tecnologia e Estatística. Ed. Imprensa Nacional. Rio de Janeiro, 1943, p. 37.

${ }^{109}$ Revista Polytechnica II vol, 1906. Typographia do Diario Official, São Paulo, 1906, p. 278/279.
} 
e no Guaraú, quinze metros, quando encontraram a rocha granítica primitiva, para que se fundasse o muro de guarda em terrenos incontestavelmente impermeáveis. A drenagem do leito desta barragem foi, por conseqüência, muito trabalhosa devido aos bancos rochosos que tiveram que ser cortados para o prolongamento dos drenos.

No caso desses dois reservatórios, os engenheiros rejeitaram a proposta de barragens de alvenaria, tendo em vista o resultado desses laudos, que apontavam como principal problema a falta de resistência do solo da fundação, e a necessidade de se prevenirem possíveis desastres, a exemplo do que ocorrera em alguns países, como na França, em Epinal, onde a barragem de Bouzey, ao se romper em 27 de abril de 1895, provocou a morte de 93 pessoas. ${ }^{110}$

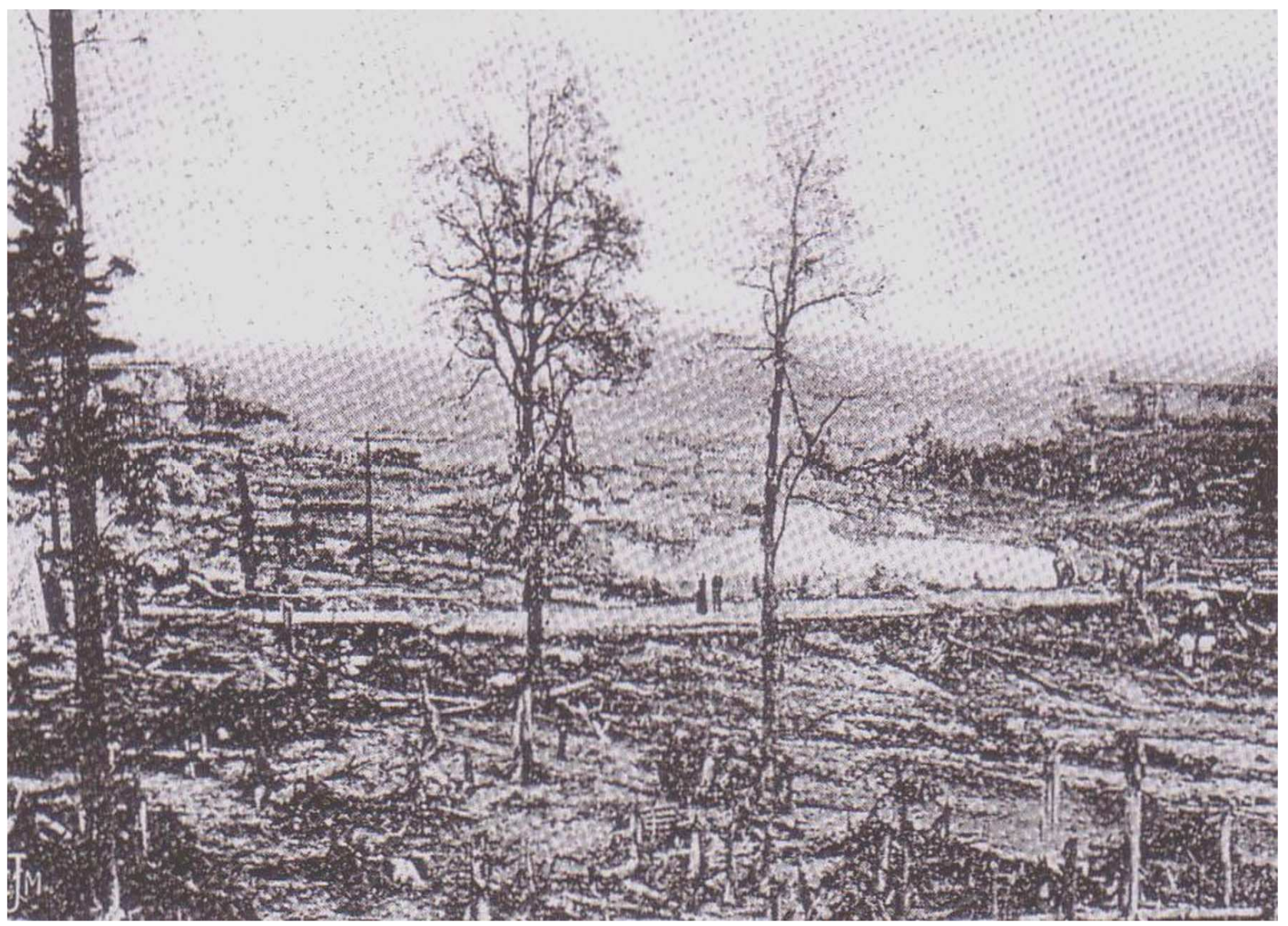

Rupture de la digue de Bouzey

\footnotetext{
${ }^{110}$ La Technique Sanitaire. Revue de L'Art de L'Ingénieur et de L'Hygiéniste Municipal. Année, ㄲos. 9 et 10. Lyon, 1907, p.283.
} 


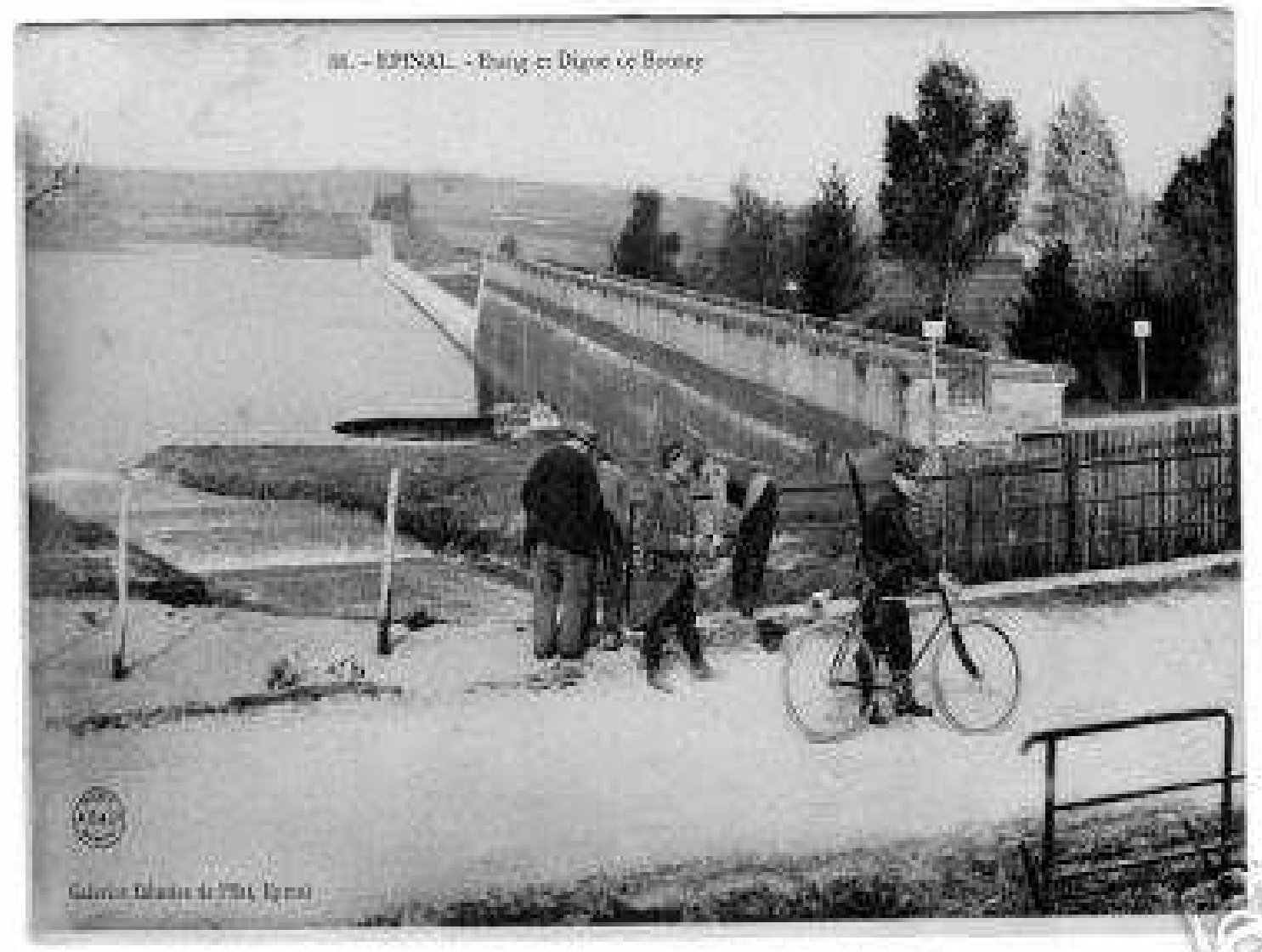

La Digue de Bouzey rétablie - $1907^{111}$

\subsection{ENGORDADOR - Antecedentes históricos}

O vale do Engordador, destinado a suprir as zonas mais altas da cidade, situado em altitude elevada, reunia, desde 1894, quatro regatos em um tanque de acumulação, de onde partia um conduto de $300 \mathrm{~mm}$ de diâmetro que elevava suas águas até a caixa do Gonçalves, garantindo a pressão das linhas adutoras.

${ }^{111}$ La Technique Sanitaire.Revue de L'Art de L'Ingénieur et de L'Hygiéniste Municipal. Année, nos.9 et 10.Lyon, 1907, p.284. 


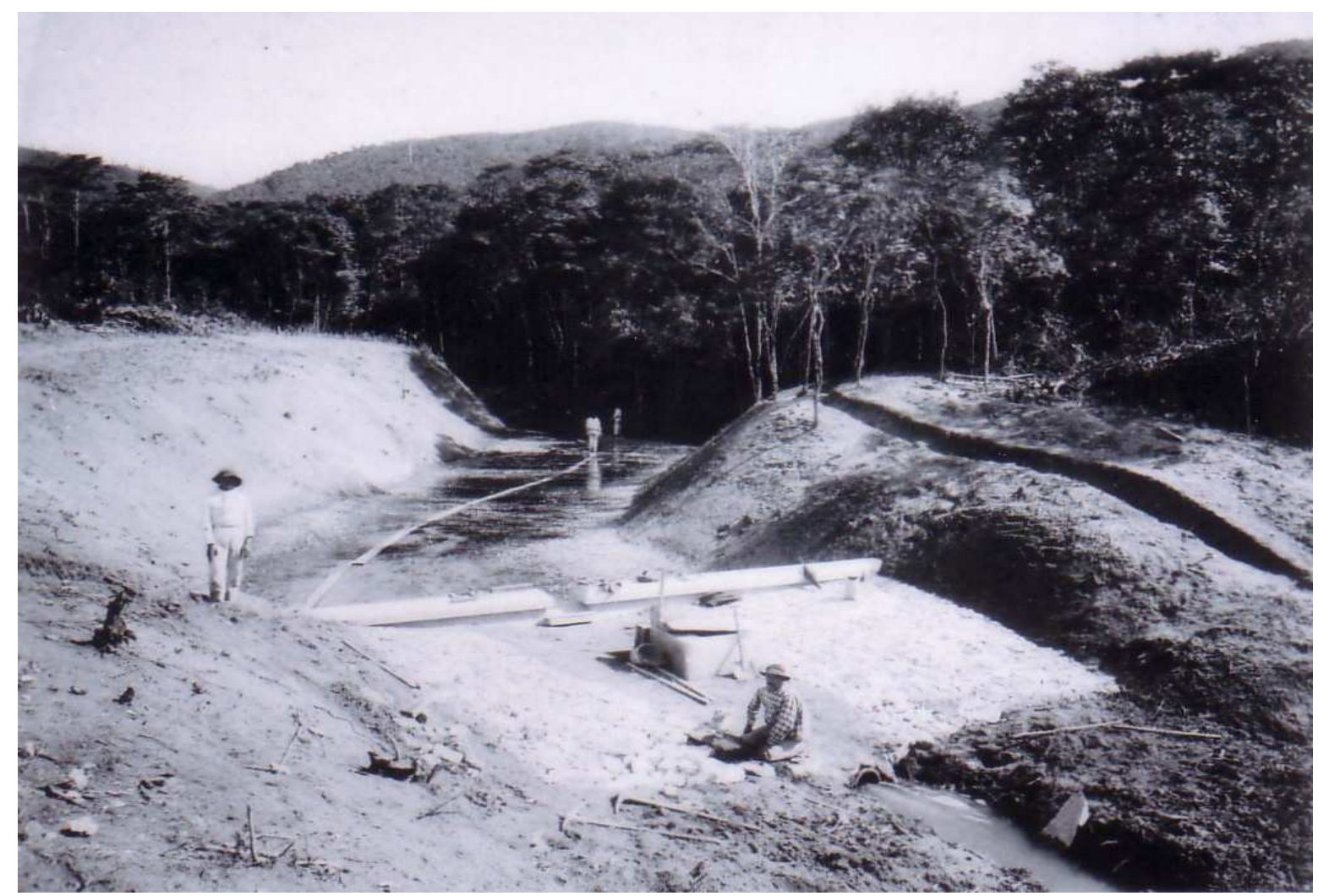

Foto P.Doumet 1894. Construção da pequena barragem do Engordador.

Em 1904, porém a Comissão de Obras Novas, diante do deficitário abastecimento da zona alta, redefinida nos novos planos altimétricos, resolve ampliar a captação das águas desse vale, construindo a barragem do Engordador, no mesmo local, onde estava a antiga, para formar o lago artificial do mesmo nome. 


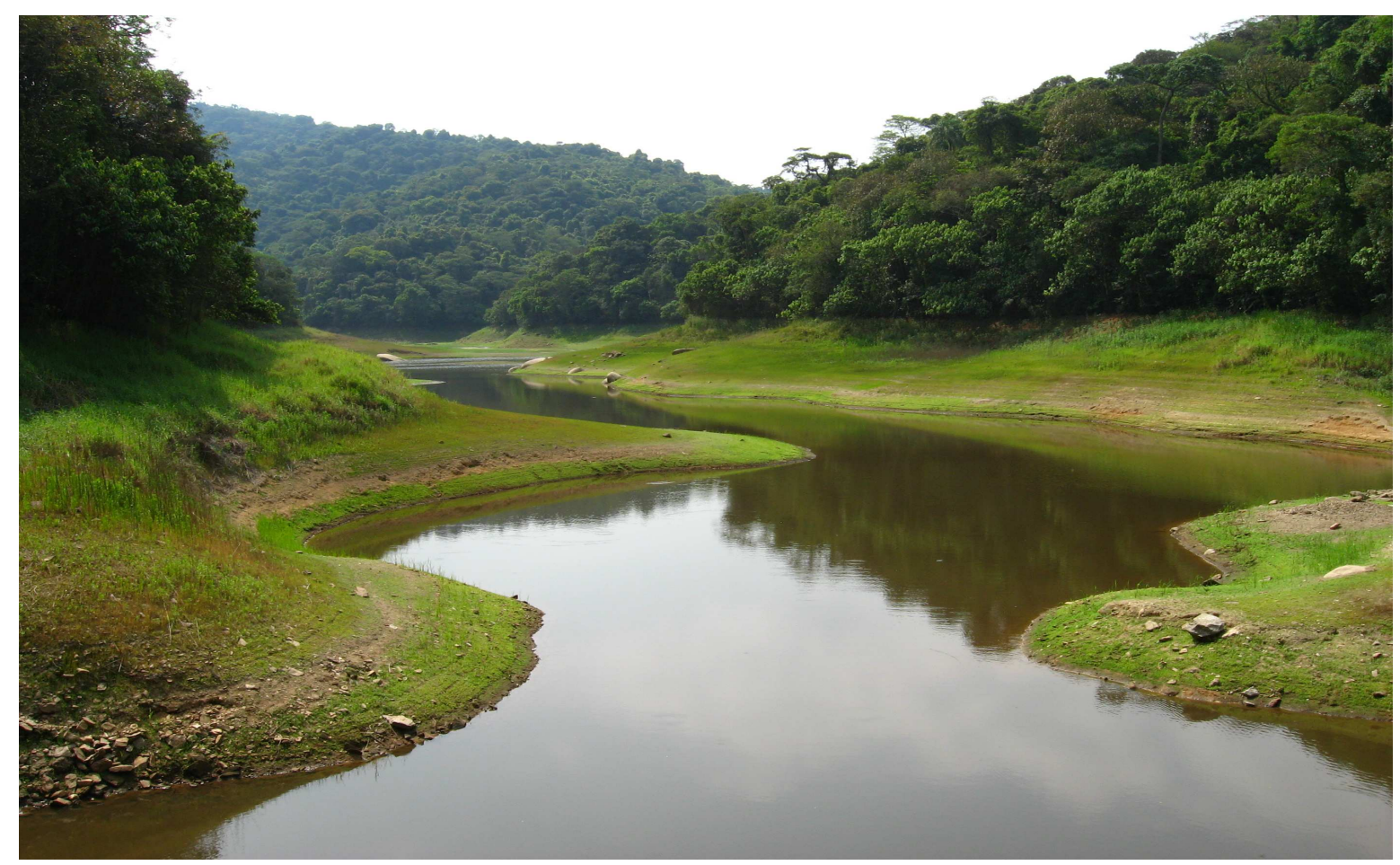

Foto de setembro de 2007, tirada da atual represa, mostrando o mesmo local onde se situava a pequena barragem de 1894 .

Foi adotado o sistema de barragem de terra, porque a altura do reservatório do Engordador de $11 \mathrm{~m}$, comportava perfeitamente essa solução construtiva. A opção recaiu sobre o sistema francês, como já dissemos, de acordo com o princípio mais aceito da homogeneidade dos materiais de construção, que, segundo os relatórios da época, representava uma garantia contra os recalques desiguais, entre os materiais de compressibilidade diversa no maciço, que acabavam provocando trincas, ou fraturas, comprometendo a segurança da obra.

Baseando-se no grande número de barragens construídas na França, a Comissão de Obras Novas projetou a do Engordador, sobre a areia, levando até o terreno impermeável apenas uma parte da obra. O maciço que constituía a barragem foi executado com material homogêneo e impermeável. Nessa região, a grande quantidade de argila, areia e cal, fez com que a escolha recaísse sobre a construção inteiramente de "corroi", sistema que consiste na mistura de argila e areia em parte iguais, e a adição de 15 litros de cal por metro cúbico, em pó ou líquido de acordo com o estado de umidade das terras, para posteriormente fazerem sua proteção através de um revestimento de cimento armado, que fazia corpo com os tubos de tomada de água, que eram do mesmo material, procurando-se evitar, 
dessa maneira, os pontos críticos por onde, às vezes, costumavam falhar obras similares.

O resultado da combinação, feita por meio de um amassador mecânico, foi lançado no corpo da barragem em camadas de 10 a 20 centímetros e comprimida por meio de um rolo, cujo peso correspondia a uma pressão de 200 k por centímetro quadrado.

De acordo com o relatório da Secretaria da Agricultura, a represa do Engordador, construída com a finalidade de manter a normalidade do funcionamento da bomba a vapor, instalada em 1904 para o aproveitamento das sobras desses córregos, dispunha de uma força para elevar a coluna d'água até cem (100) metros, traduzindo-se em 24 horas 10.000 .000 de litros, garantindo-se em época de estiagem um suprimento de mais de 5.500 .000 litros para o abastecimento geral $^{112}$, ou seja 10.000 metros cúbicos diários, o que representava, aproximadamente, a quantidade de que diminuíam os mananciais em tempo de seca. ${ }^{113}$

Inaugurada a 27 de abril de 1908, quando ainda funcionava a Comissão de Obras Novas, começou-se a deitar sobras pelo sangradouro a 14 de agosto do mesmo ano, tendo levado 109 dias para encher o reservatório, o que representava uma contribuição média diária de 4.600 .000 litros ao abastecimento da cidade. ${ }^{114}$

Segundo Arthur Motta, diretor da R.A.E., "eram precárias as condições desses mananciais, que atravessavam terrenos alagadiços, verdadeiros brejos, a julgar pela vegetação característica e a natureza do terreno". ${ }^{115}$

$E$ de acordo com o diretor, "a montante das respectivas represas não era possível o acesso dos guardas incumbidos da limpeza, de tão exuberante que estava a vegetação, fazendo-se necessárias roçadas, para se conseguir expurgar substâncias orgânicas em sedimentação (detritos vegetais), que obstruíam os leitos dos córregos, como também, a drenagem superficial das margens de dois mananciais, baixando o nível do ladrão, conseguindo-se a dessecação dos pântanos que ladeavam os cursos d'água". ${ }^{116}$ Segundo sua apreciação eram impotáveis as

\footnotetext{
${ }^{112}$ Relatório da Secretaria dos Negócios da Agricultura, Comércio e Obras Públicas do Estado de São Paulo, apresentado ao Presidente do Estado pelo Secretário da Agricultura. Ano de 1904,Typographia Brasil de Carlos Gerke, São Paulo, 1905, p.236.

${ }^{113}$ Ibidem, ano de 1905, Typographia Brasil de Rothschild \& Co., São Paulo, 1906, p.227.

${ }^{114}$ FONSECA, Filomena Pugliese. Equipamento do Engordador: testemunho arqueológico industrial da captação de água na cidade de São Paulo. Dissertação de Mestrado. São Paulo, 2003, p.43.

${ }^{115}$ Relatório da Repartição de Águas e Esgotos de São Paulo, apresentado ao Secretário da Agricultura, pelo seu Diretor. Typographia Brazil de Rothschild \& Co., São Paulo, 1907, p.4

${ }^{11}$ Ibidem, p.4.
} 
águas desses regatos durante o mês de fevereiro do mesmo ano, havendo apenas uma melhora em suas condições com as sucessivas limpezas e outras providências de caráter provisório que foram tomadas por seu intermédio.

Por esse mesmo relatório, em razão de seus caracteres físicos, essas águas, onde sobressaía a cor (amarelo esverdeada) pelo excesso de substâncias orgânicas em solução e corpos em suspensão, foram consideradas suspeitas, uma vez que ultrapassavam os limites prescritos como índices de potabilidade. Posteriormente. medidas preventivas foram tomadas alterando a composição química e as qualidades físicas da água destinada ao abastecimento da população paulistana.

O problema com que as autoridades se defrontavam consistia na melhoria do líquido que a população deveria consumir, com a instalação nas represas de caixas de decantação e dispositivos que permitissem lavar os depósitos, sem que com isso as linhas adutoras ficassem comprometidas de uma parte de sua descarga normal. Os ribeirões do Engordador, bem como as caixas que os reuniam, ressentiam-se da falta desse melhoramento, devido, segundo o diretor da R.A.E., "à falta de recursos da verba". ${ }^{117}$

No Engordador, porém, a estiagem prolongada de 1906 obrigou o funcionamento da bomba elevatória a vapor por 24 horas, bombeando os ribeirões do vale, para auxiliar no consumo, o que impediu a limpeza do lago e sua formação. Contratada com a Companhia Mechanica", foi orçada em 115:000\$000.

${ }^{117}$ Ibidem, p.4. 


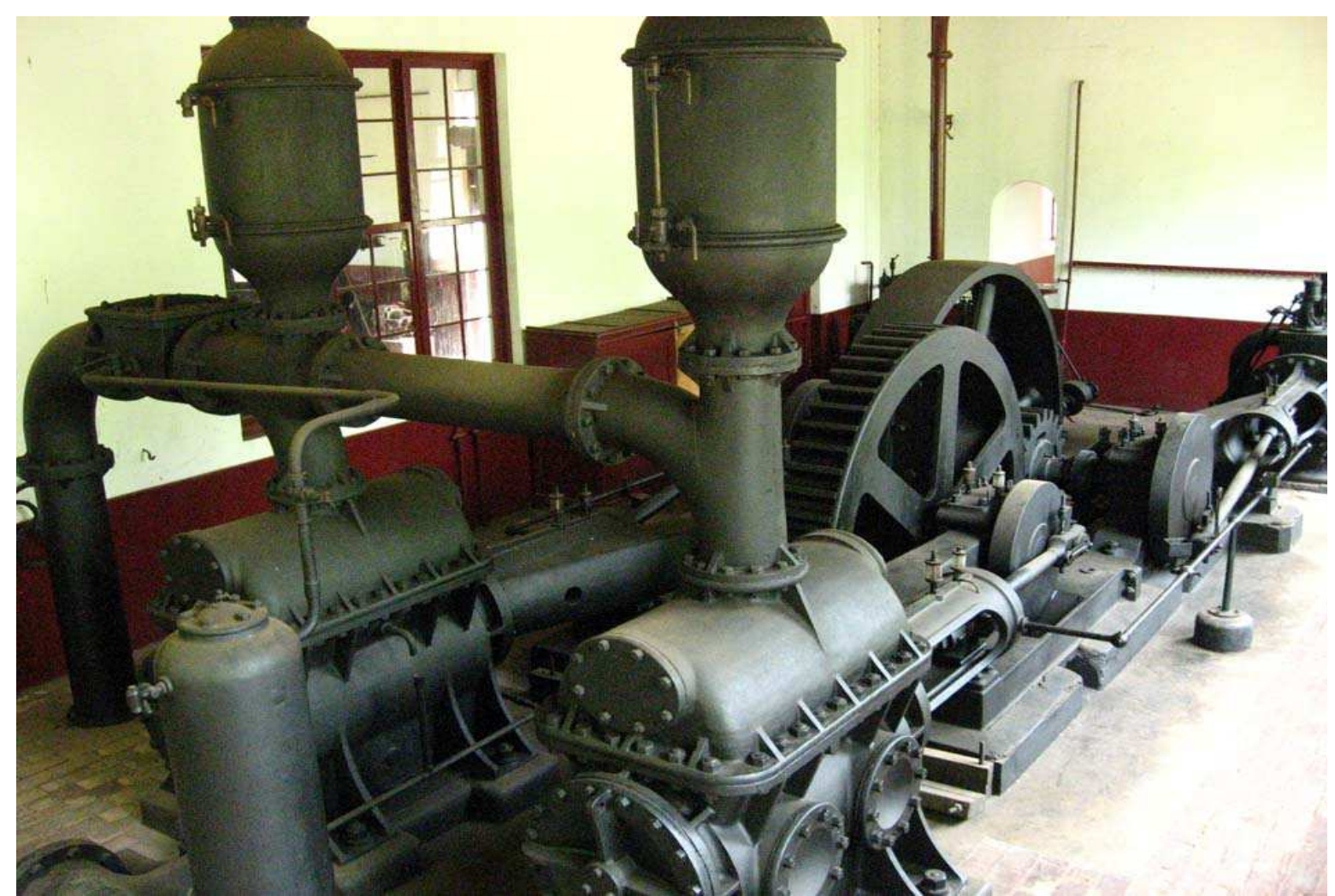

Foto das bombas do Engordador - setembro de 2007.

Antes de ser definitivamente escolhido o sistema de represamento com as tomadas d'água no corpo da barragem, o autor do projeto estudava as opções que se the apresentavam no momento: atravessar a barragem apenas com um tubo de fundo, estabelecendo, em seguida, a montante, uma torre de tomada d'água, ou transpor o contraforte em túnel, e fixando, da mesma maneira, a torre. Ambos os sistemas, porém, pareceram perigosos, (rochas fendilhadas, e blocos soltos), motivos pelos quais foi rejeitada a construção da barragem em alvenaria.

As obras acessórias de uma barragem compreendem uma ou mais tomadas d'água, uma descarga geral para o escoamento do reservatório, vertodores de superfície ou de flanco, valas de proteção.

No Engordador, foram feitos três aquedutos de alturas diferentes, sendo as duas primeiras de tomadas d'água e a última de descarga. As comportas funcionam a uma pressão inferior a quatro metros.

O tubo vertical de $1 \mathrm{~m}$ de diâmetro interior e de $11 \mathrm{~m}$ de altura, colocado no eixo da barragem faz a comunicação com os três tubos horizontais, também circulares e de diâmetros diversos: 1m; 1,20m; e 1,40m, que permitem o escoamento das águas para o aqueduto inferior. 
Enquanto o nível não baixar até a plataforma inferior, a segunda e terceiras comportas ficam protegidas cada uma, por sua barragem móvel de corrediças, de maneira que nenhum depósito se produz junto à comporta.

Segundo o autor do projeto, tratava-se de um sistema simples e da maior confiabilidade, se houvesse apenas a preocupação com o escoamento da água, pareceria ter havido exagero na fixação dos diâmetros dos tubos que atravessavam a barragem.

Entretanto, três considerações, foram relevantes em sua decisão:

Tornar possível a inspeção dos tubos para conservá-los limpos e principalmente garantir o acesso às comportas, quando o reservatório estivesse cheio, para consertar eventuais defeitos em sua impermeabilidade; facilitar o rápido escoamento da água por ocasião das lavagens, permitindo a retirada do lodo que se acumulasse junto à comporta; aproveitar os tubos como escoadouro para as enxurradas e grandes chuvas, durante a construção das represas.

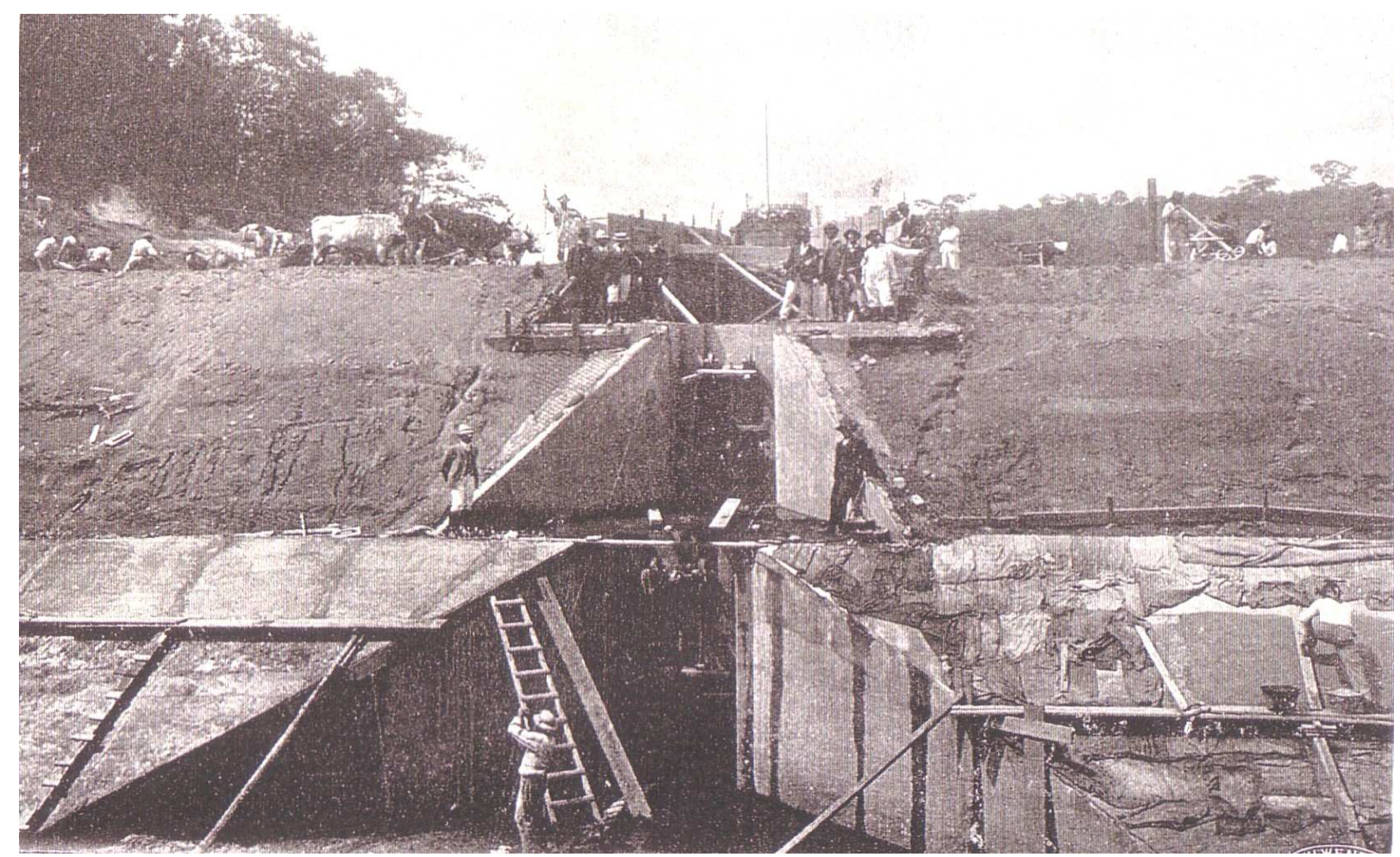

Foto de 1906, construção da barragem do Engordador.

Luiz Betim Paes Leme, chefe da Comissão de Obras Novas, assim justificava o projeto do Engordador: 
A construcção do tubo vertical de cimento armado dentro do corpo da barragem, substituindo a torre de tomada da agua, era a solução que mais se coadunava com a orientação do projecto, pois, reduzimos assim ao minimo possivel a concentração das cargas. Além de tudo, a torre de tomada de agua fóra do corpo da barragem é sempre uma obra consideravel, pede fundações extensas e grandes espessuras, pois, além de seu proprio peso, essas torres devem resistir á pressão do vento por ocasião de aguas baixas. ${ }^{118}$ (LEME, 1906)

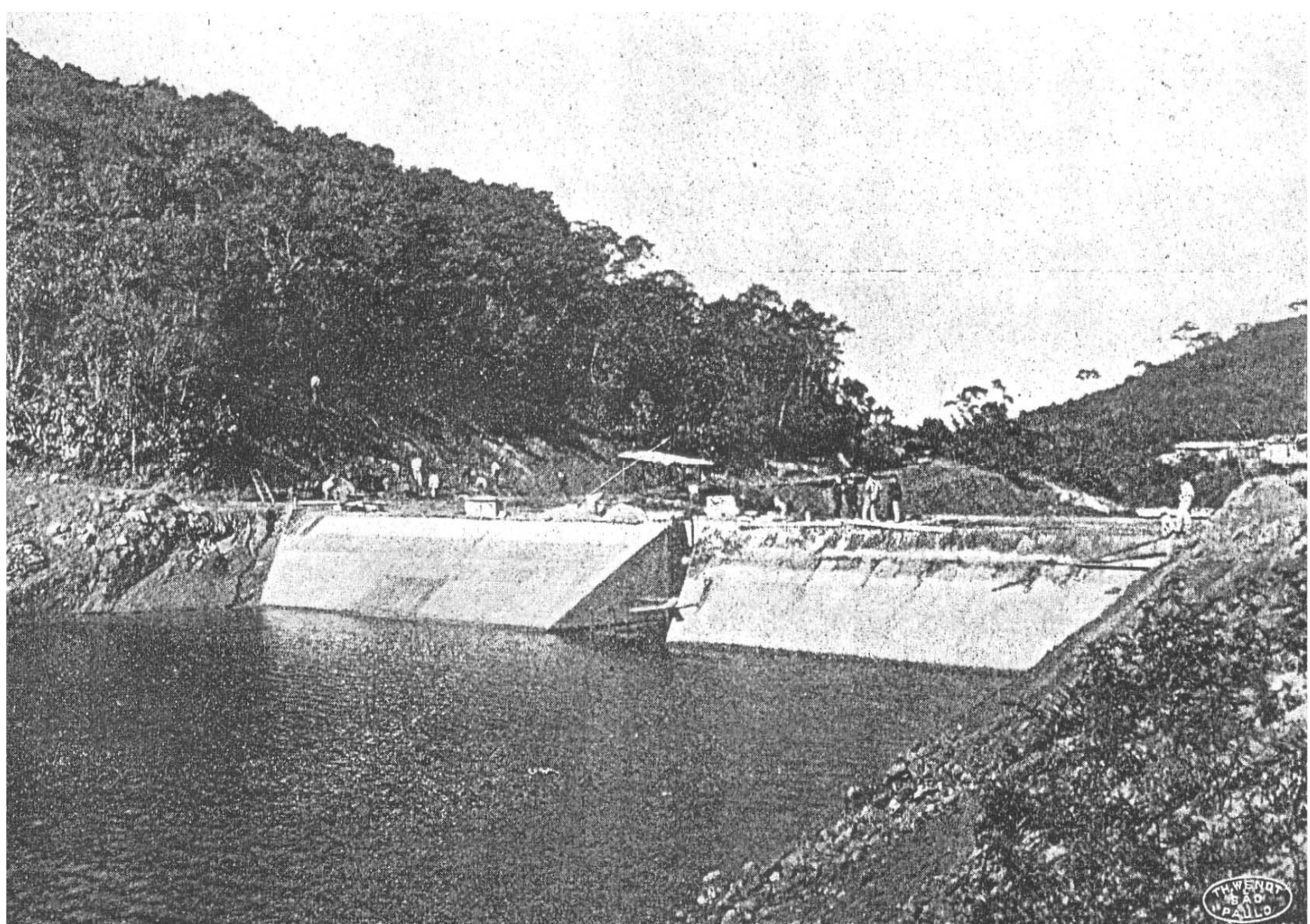

Foto de 1907, da barragem do Engordador no momento da formação do lago artificial.

\footnotetext{
${ }^{118}$ Revista Polytechnica. Vol II, Ed. Typographia do Diário Official, São Paulo, 1906, p.282.
} 


\subsubsection{Pesquisa de Campo do Engordador}

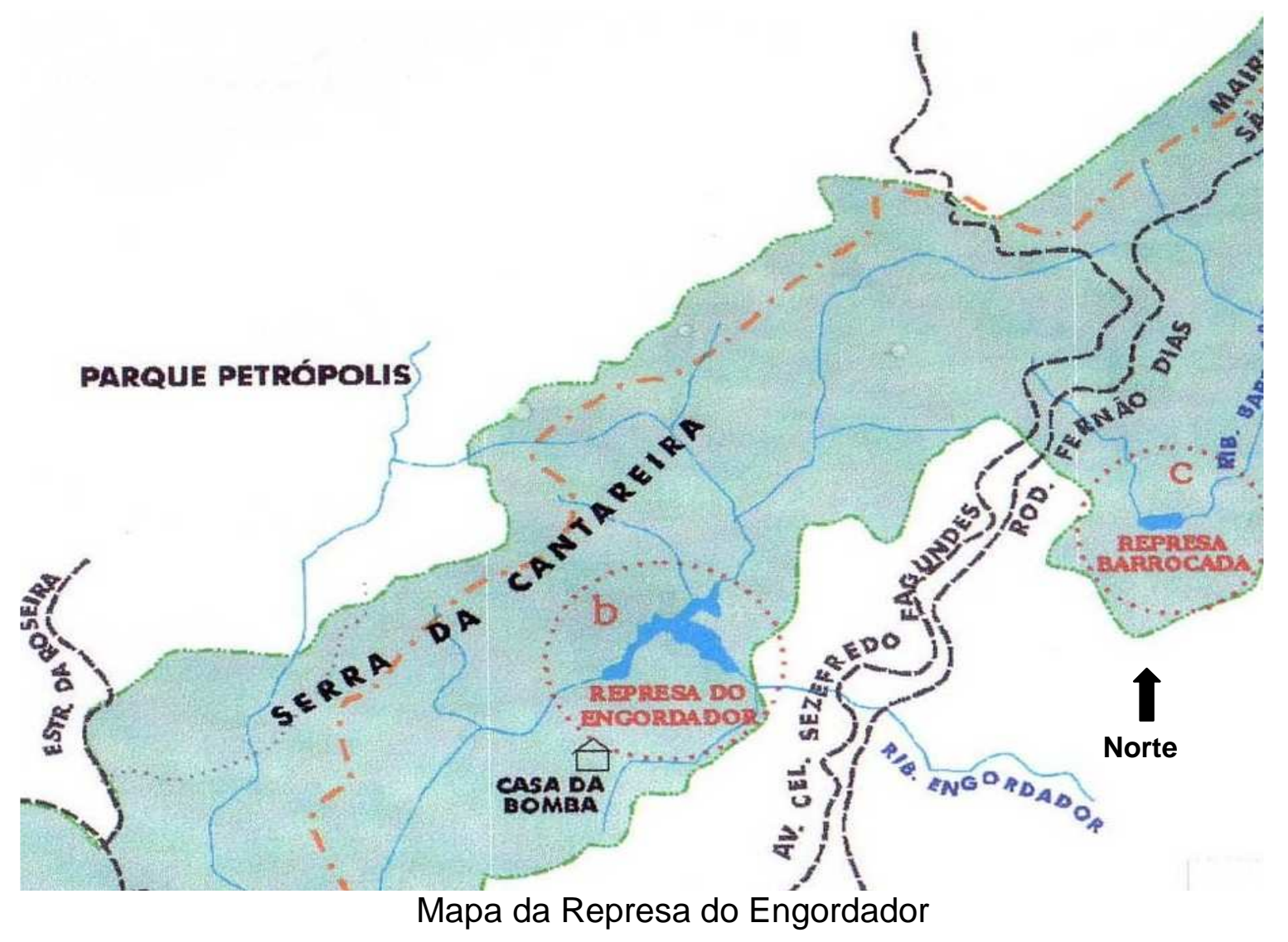

Com o trabalho de campo, foi possível complementar o histórico que envolveu a construção da barragem, com a técnica de vanguarda que já caracterizava a engenharia de então, estudando-se também, sua localização geográfica, suas características, seu estado atual de conservação, as modificações sofridas ao longo do tempo, sua função inicial e atual, e a possibilidade de reuso, como parte integrante de um roteiro turístico, com os demais reservatórios, que implantado, poderia resgatar o abastecimento de água no começo do século $X X$. Sua localização dentro dos núcleos de visitação, aliado à beleza da natureza, oferece condições logísticas para sua implantação.

Detalhe mapa da Serra da Cantareira.

Atualmente a represa do Engordador, faz parte da área de visitação do núcleo Engordador do Parque Estadual da Cantareira, situado nas coordenados geográficas: S: 2324 '10.42” e W: 46³5'13.91”, U. T.M. 361.745/7429.153, na altura do no 19.100, da avenida Sezefredo Fagundes, próximo à Rodovia Fernão Dias, no 
bairro da Cachoeira, na Zona Norte da cidade de São Paulo. O acesso ao publico é facilitado com a linha de ônibus Cachoeira-Tucuruvi.

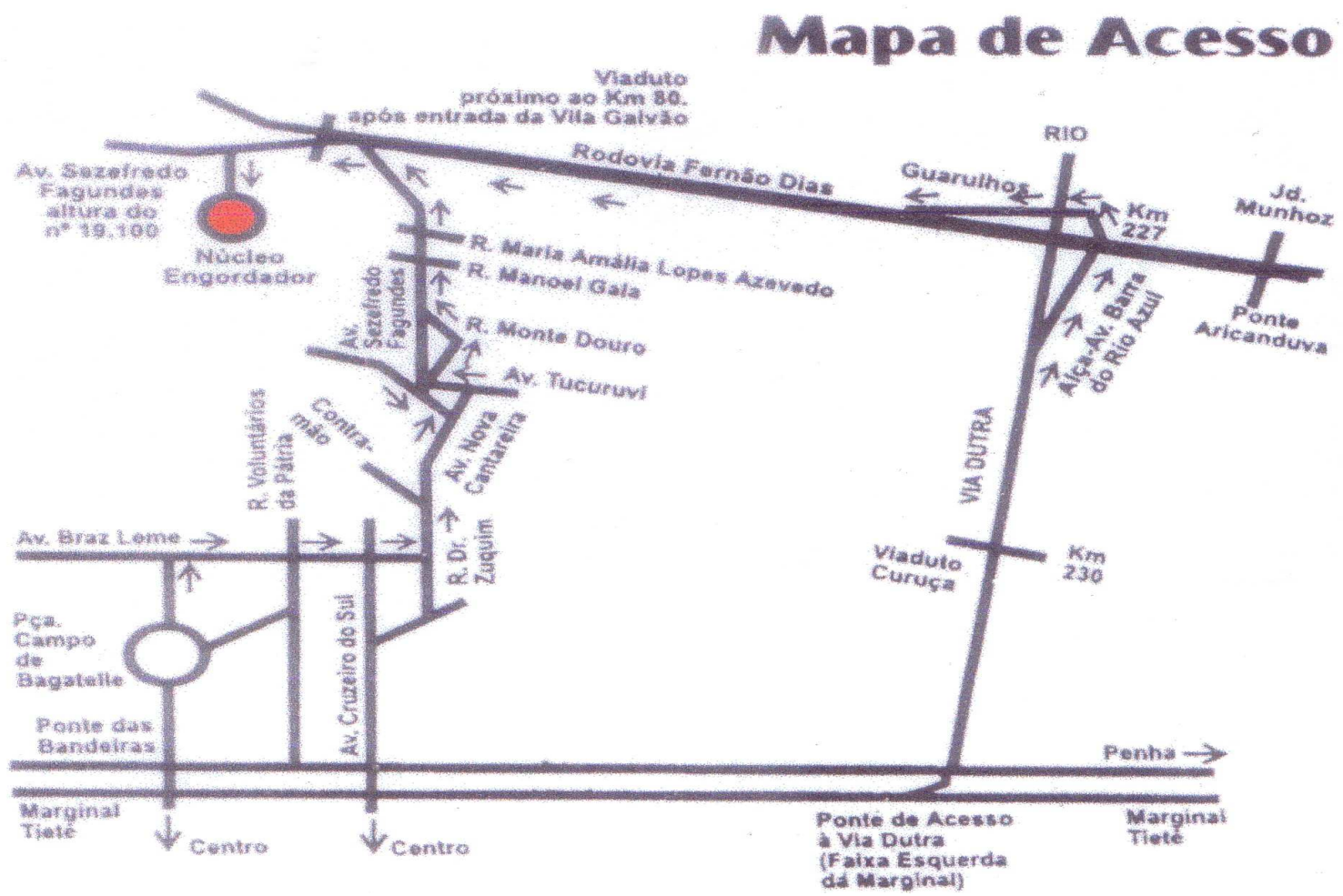

Croquis dos acessos ao reservatório do Engordador

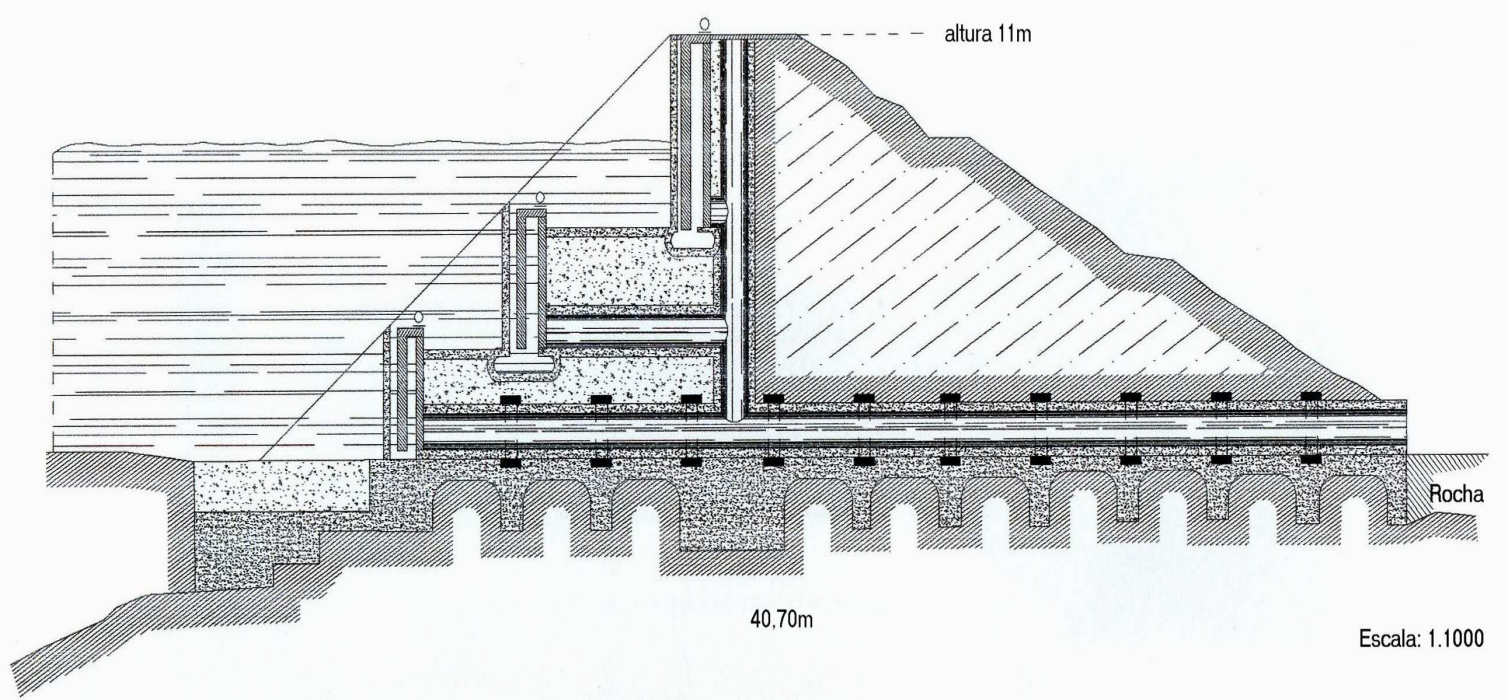

Reprodução do croquis da barragem do Engordador, feita a partir do desenho original de 1905. 
A barragem, por sua vez, localiza-se nas coordenadas, UTM 0337810/7410988, na altitude de $851 \mathrm{~m}$, o seu coroamento tem $5.80 \mathrm{~m}$ largura por $48,30 \mathrm{~m}$ de comprimento, com o vertedouro de $4 \mathrm{~m}$ de largura, e capacidade de armazenamento de $540.000 \mathrm{~m}^{3}$.

A represa do Engordador, foi capaz de armazenar e distribuir água, durante cem dias ao reservatório da Avenida; encontrando-se atualmente desativada, segundo técnicos da SABESP, mantém a mesma capacidade de armazenamento.

Ao longo desses últimos anos, foram constantes as obras de manutenção na barragem, e anualmente os técnicos fazem seu parcial esvaziamento, nos períodos chuvosos, e foi esse o momento escolhido para o trabalho de campo, nos meses de setembro e outubro de 2007, para que fosse estudado o mecanismo das comportas, e aferidas as medidas da planta original.

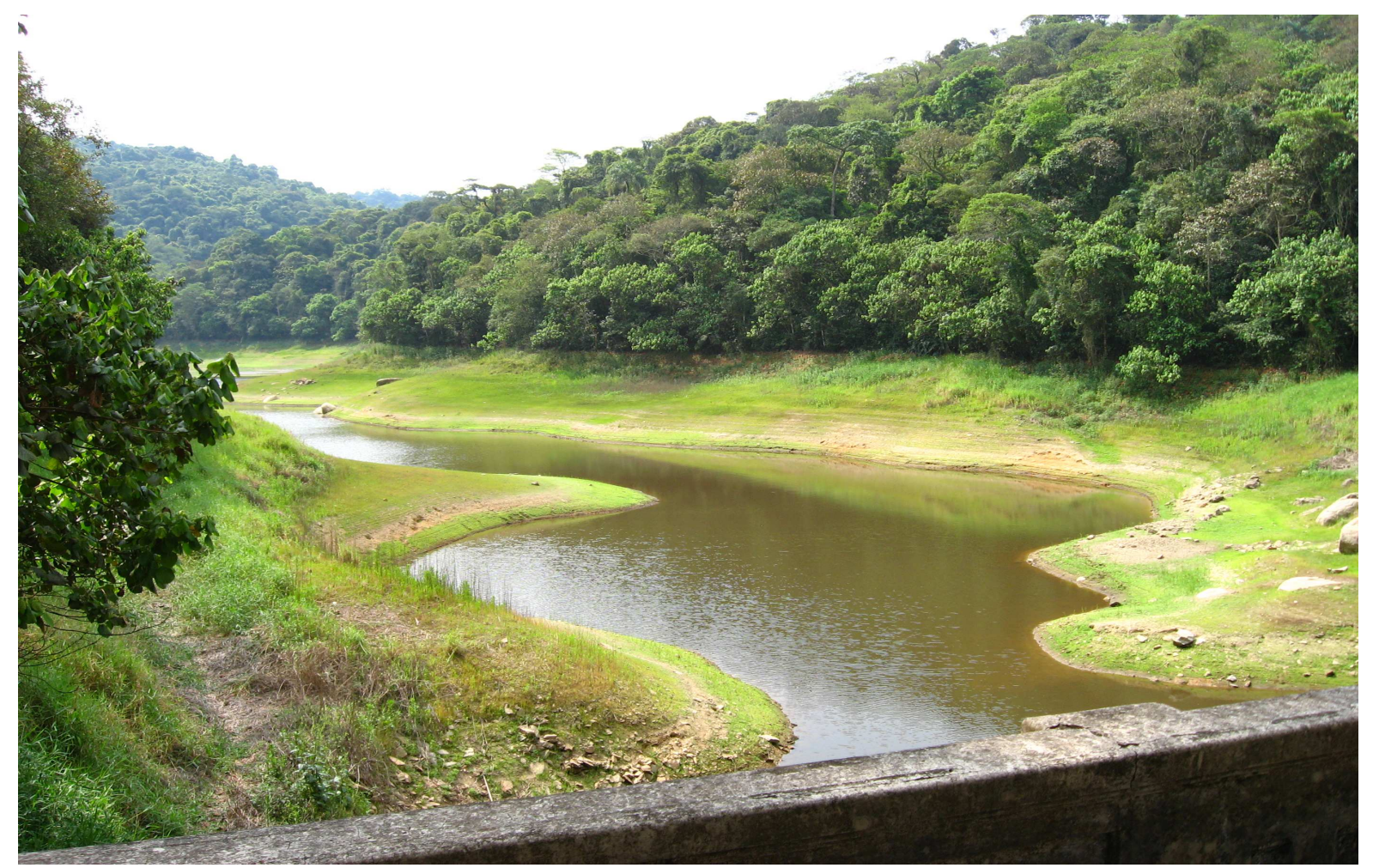

Foto do lago do Engordador - outubro de 2007. 


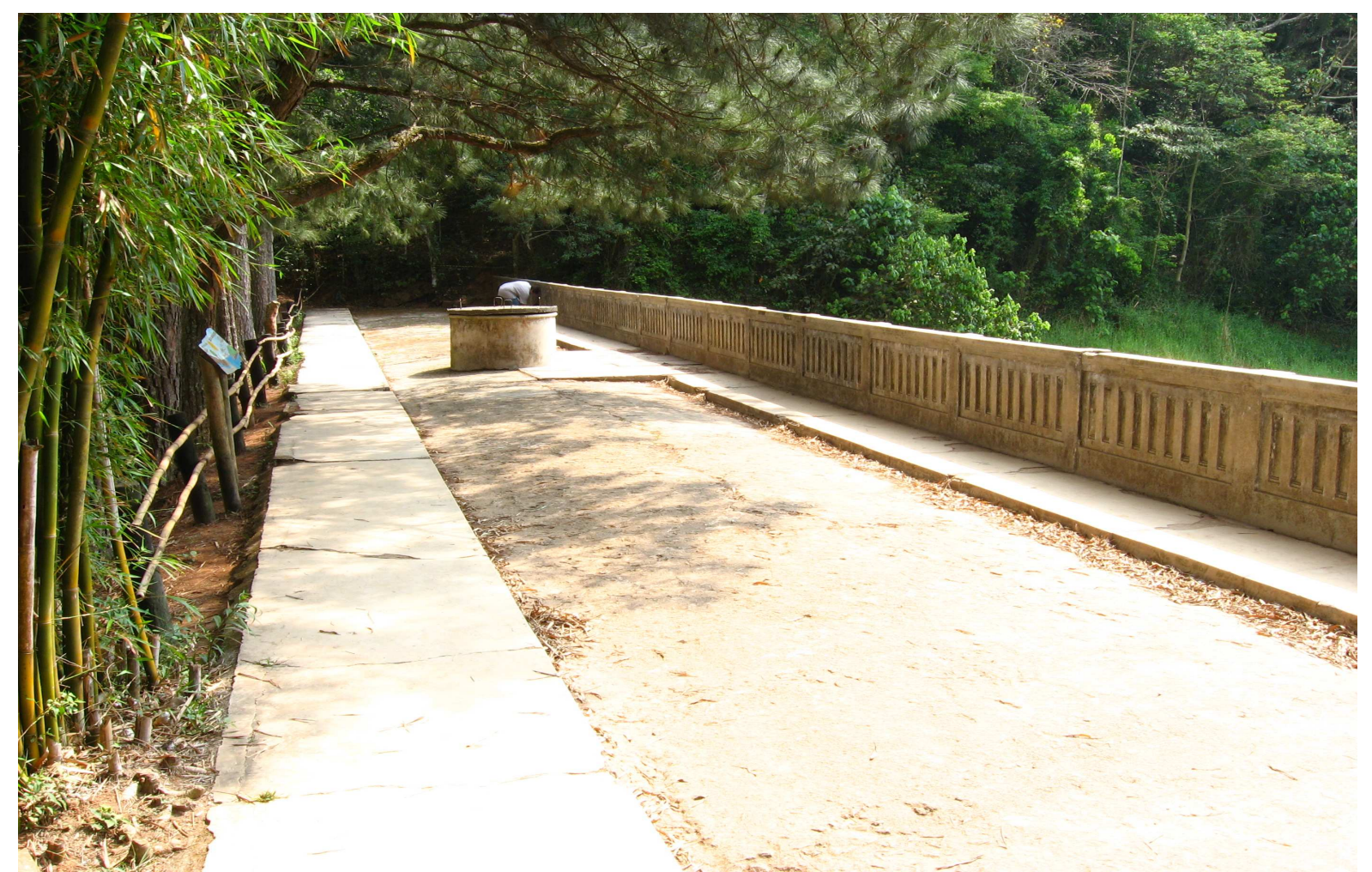

Foto de vista parcial do coroamento da barragem - outubro de 2007

Foi possível verificar no reservatório, parcialmente vazio, as tubulações de tomada d'água e de descarga, como se vê na foto, com alturas distintas, mencionadas no relatório da R.A.E., ${ }^{119}$ onde se observou como funciona a barragem móvel de corrediças, suas fases que tornam estanques cada compartimento, e representam uma segurança contra possíveis rompimentos pelo acúmulo de água junto à comporta.

Constatou-se também, claramente a existência de fissuras na chapa de concreto armado, que é constantemente restaurada, e sinais de vandalismo, com os grafismos em toda a extensão do coroamento interno da barragem, em que pese a vigilância ostensiva dos guardas florestais.

\footnotetext{
${ }^{119}$ Revista Polytechnica II vol, 1906. Ed. Typographia do Diario Official, São Paulo, 1906, p. 281.
} 


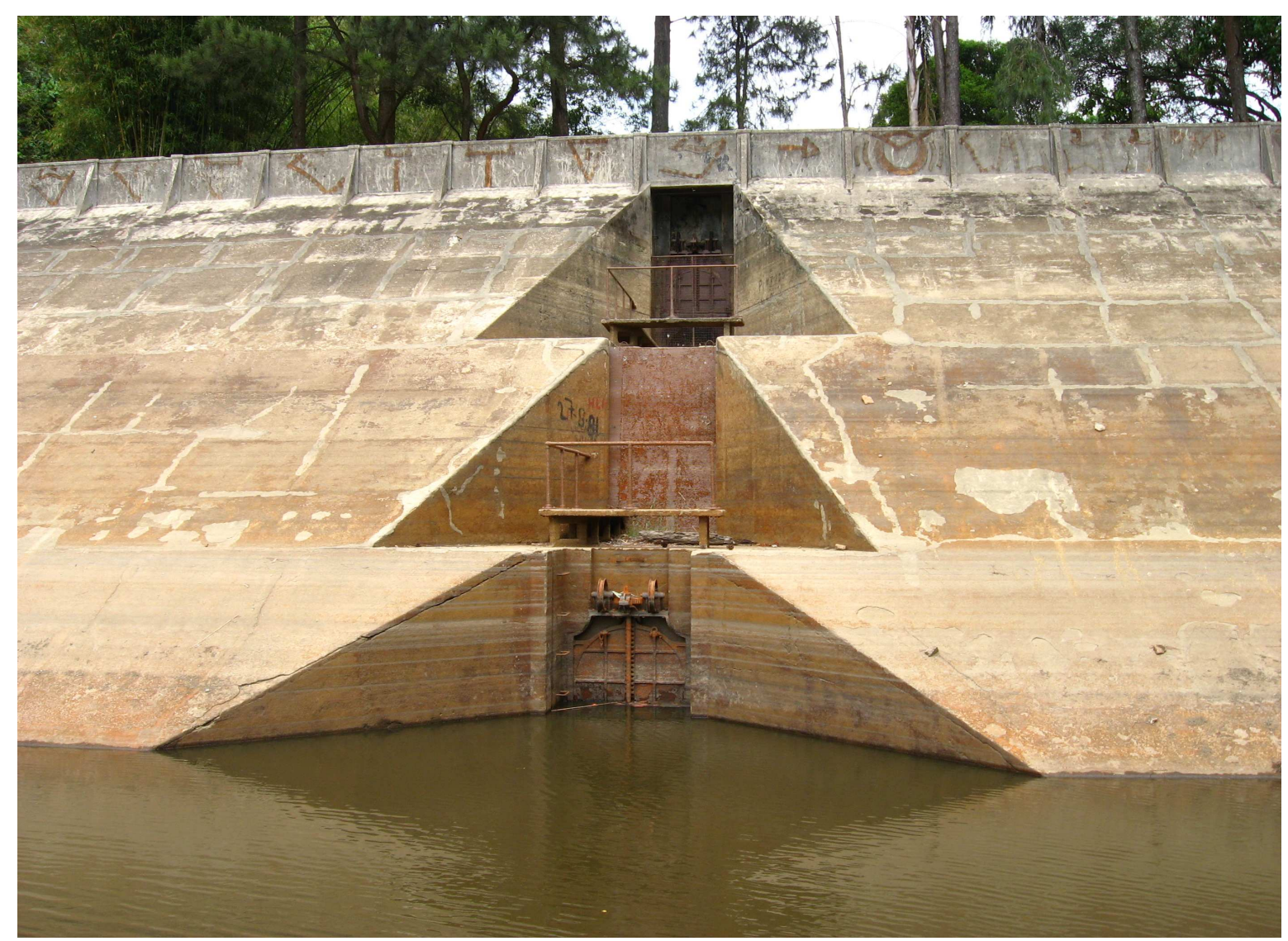

Foto de outubro de 2007, com o detalhe das três etapas das eclusas.

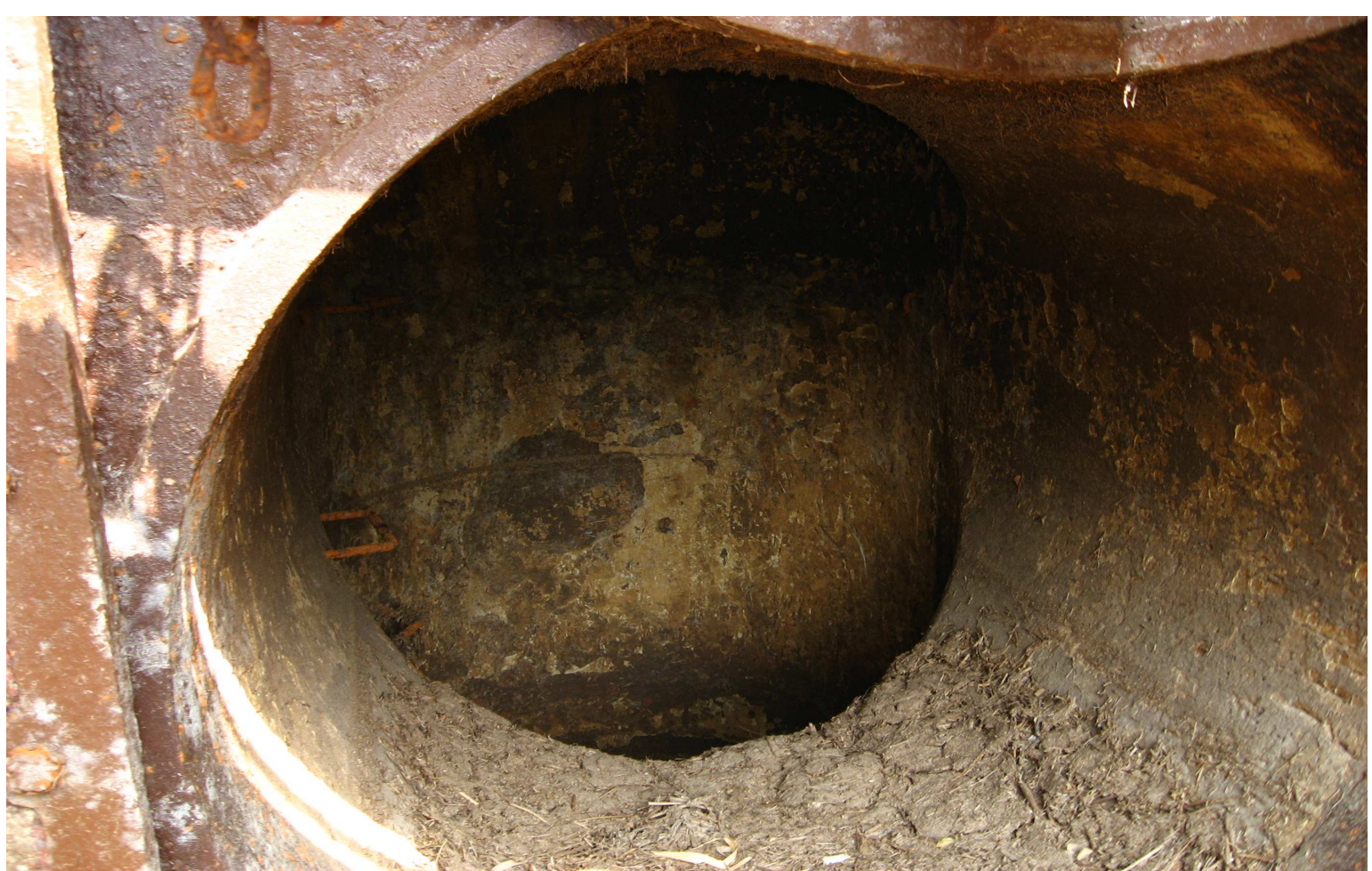

Tubo vertical fotografado em Outubro de 2007 


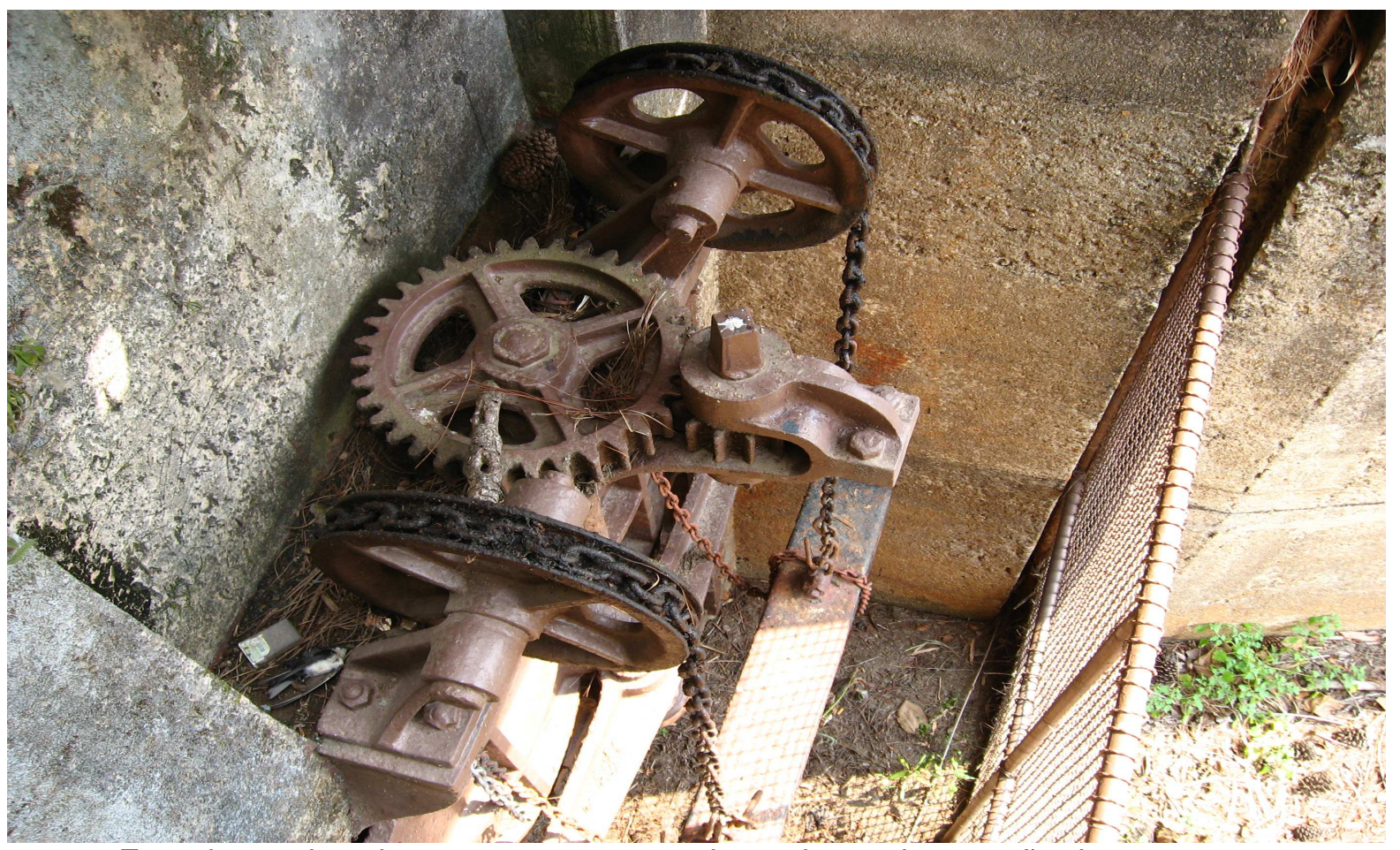

Foto de outubro de 2007, com o mecanismo de movimentação das comportas

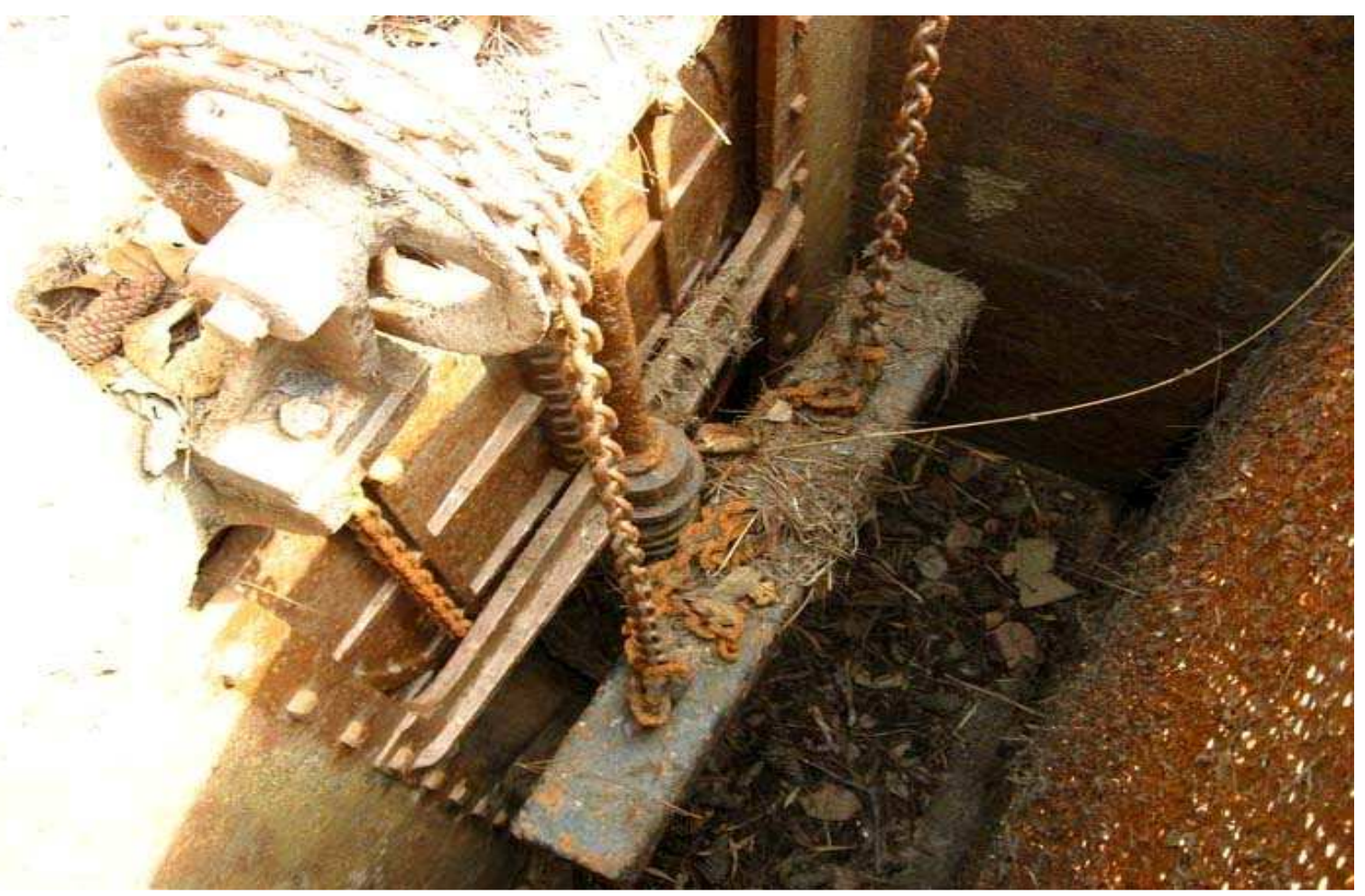

Foto de outubro de 2007, o mecanismo visto de outro ângulo. 


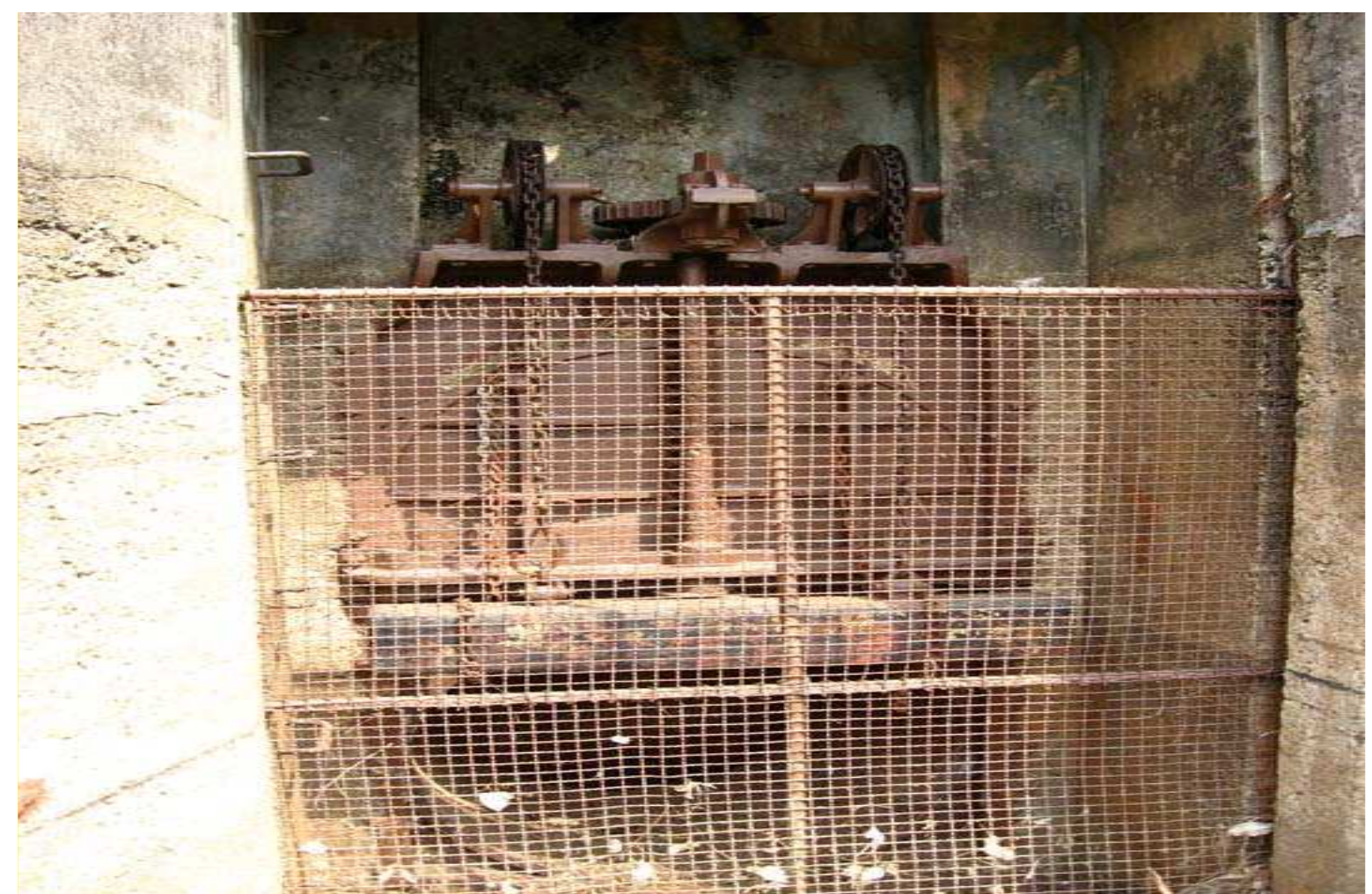

Foto de outubro de 2007.Grades de proteção do sistema de engrenagens das comportas.

Constatou-se que as engrenagens que movem as comportas estão sofrendo um processo acelerado de deterioração seja pela ferrugem, ou pelo um acúmulo de detritos de origem vegetal. 


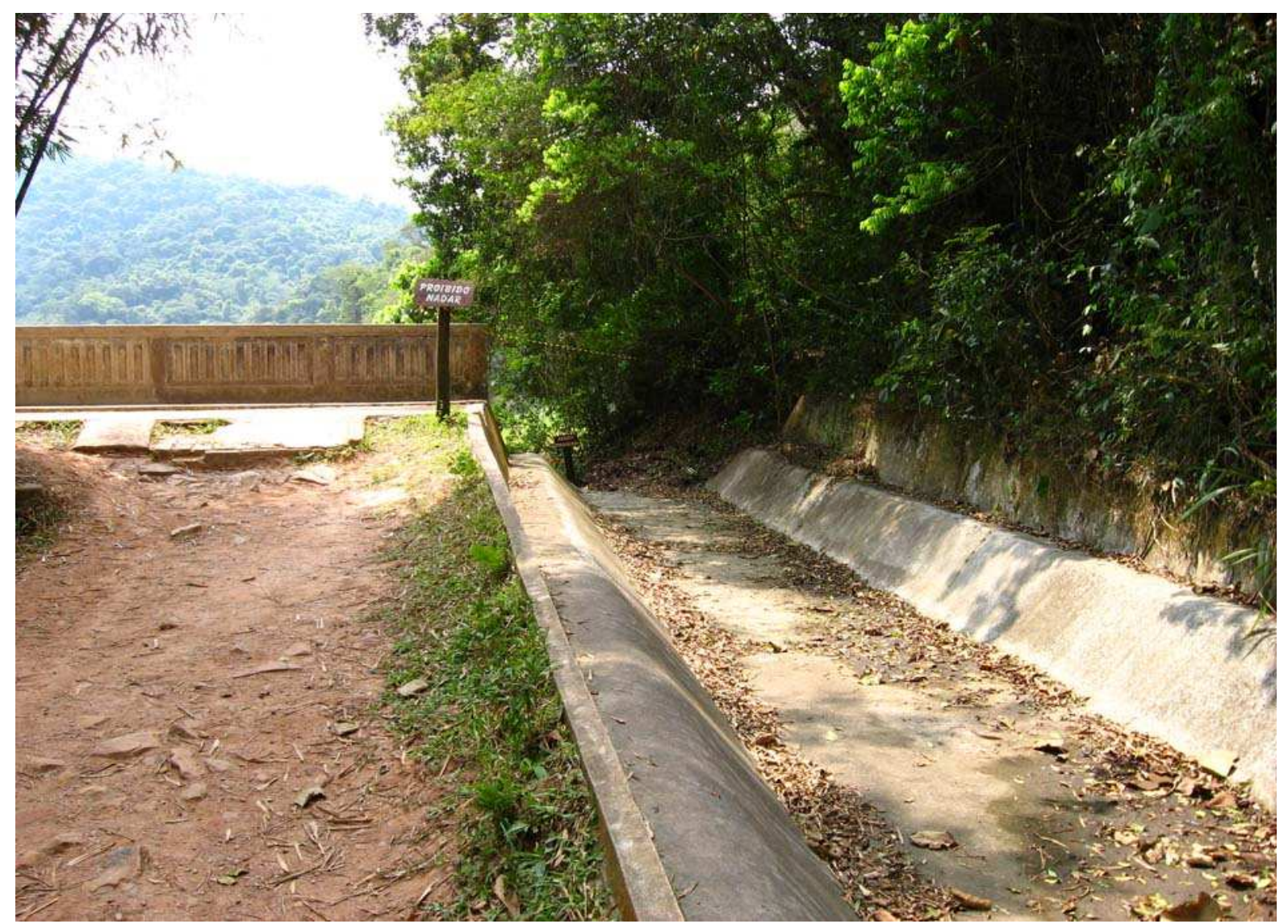

Foto de outubro de 2007 - detalhe do vertedouro.

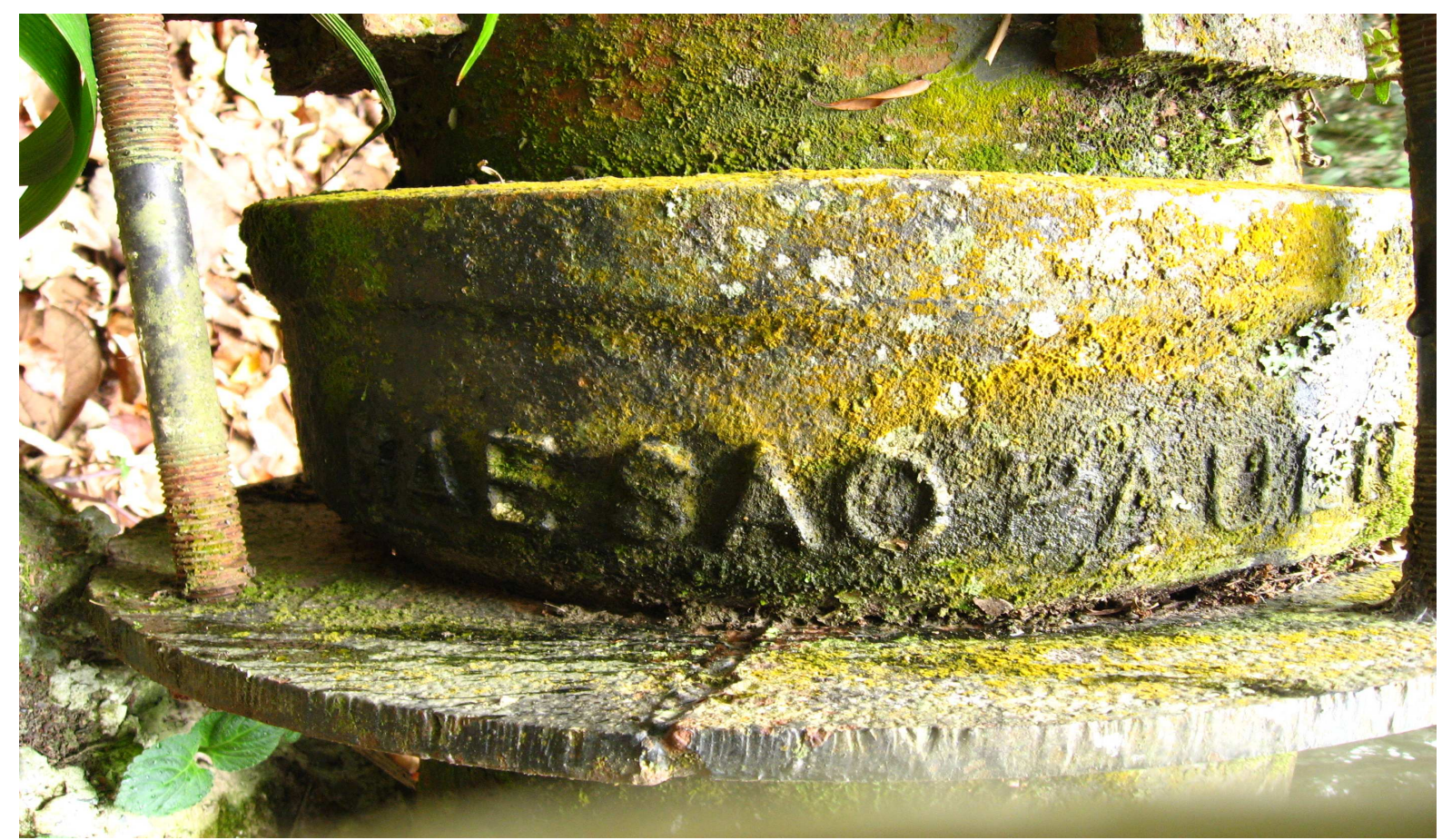

Foto de outubro de 2007, cano de 300 mm de saída da barragem gravado R.A.E. SP 


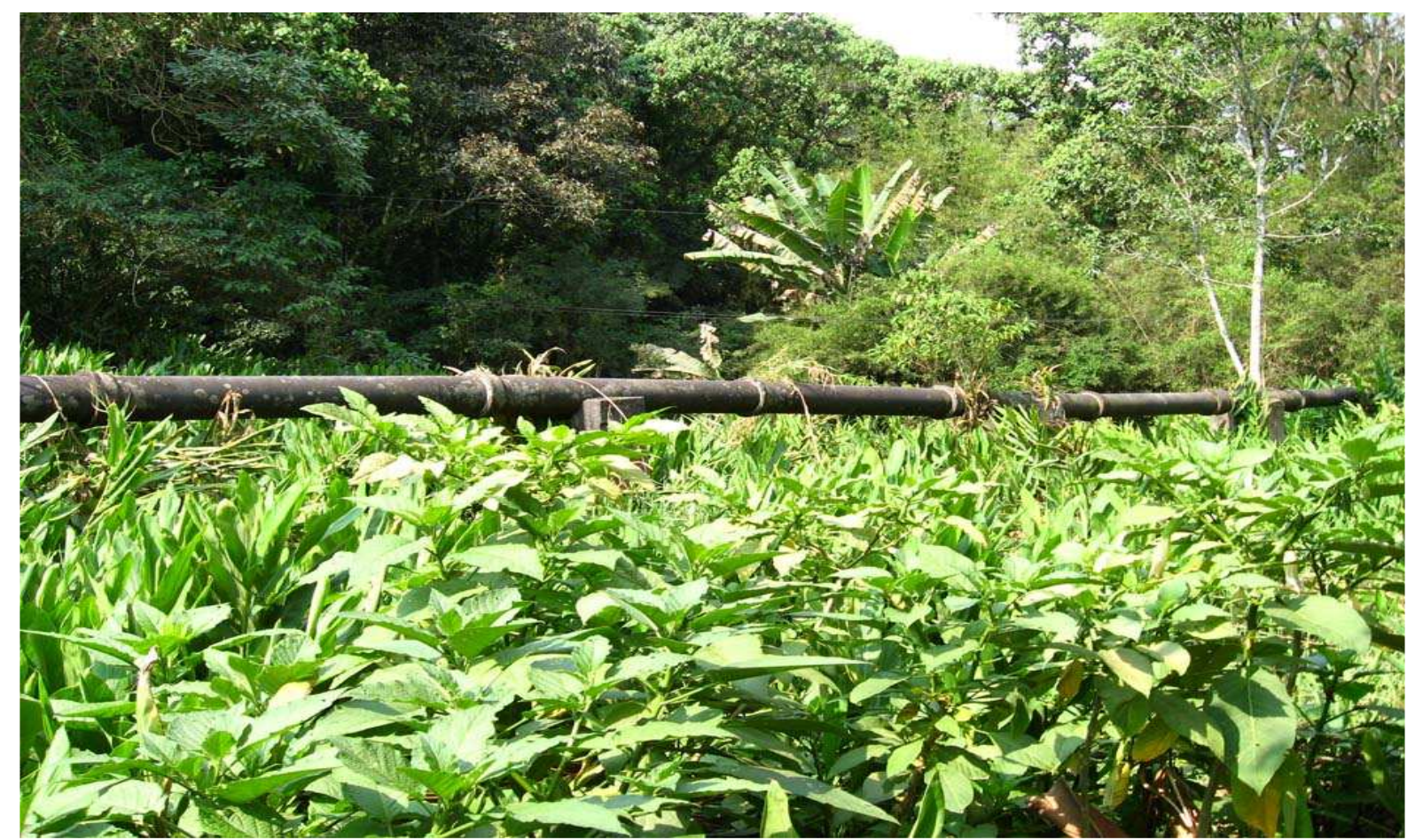

Foto de outubro de 2007, adutora que conduzia as águas da represa em direção à caixa do Gonçalves, para a rede distribuidora.

Esta adutora, que durante anos conduziu as águas para o reservatório da Avenida, está desativada, notando-se à direita da foto, um pronunciado desnível.

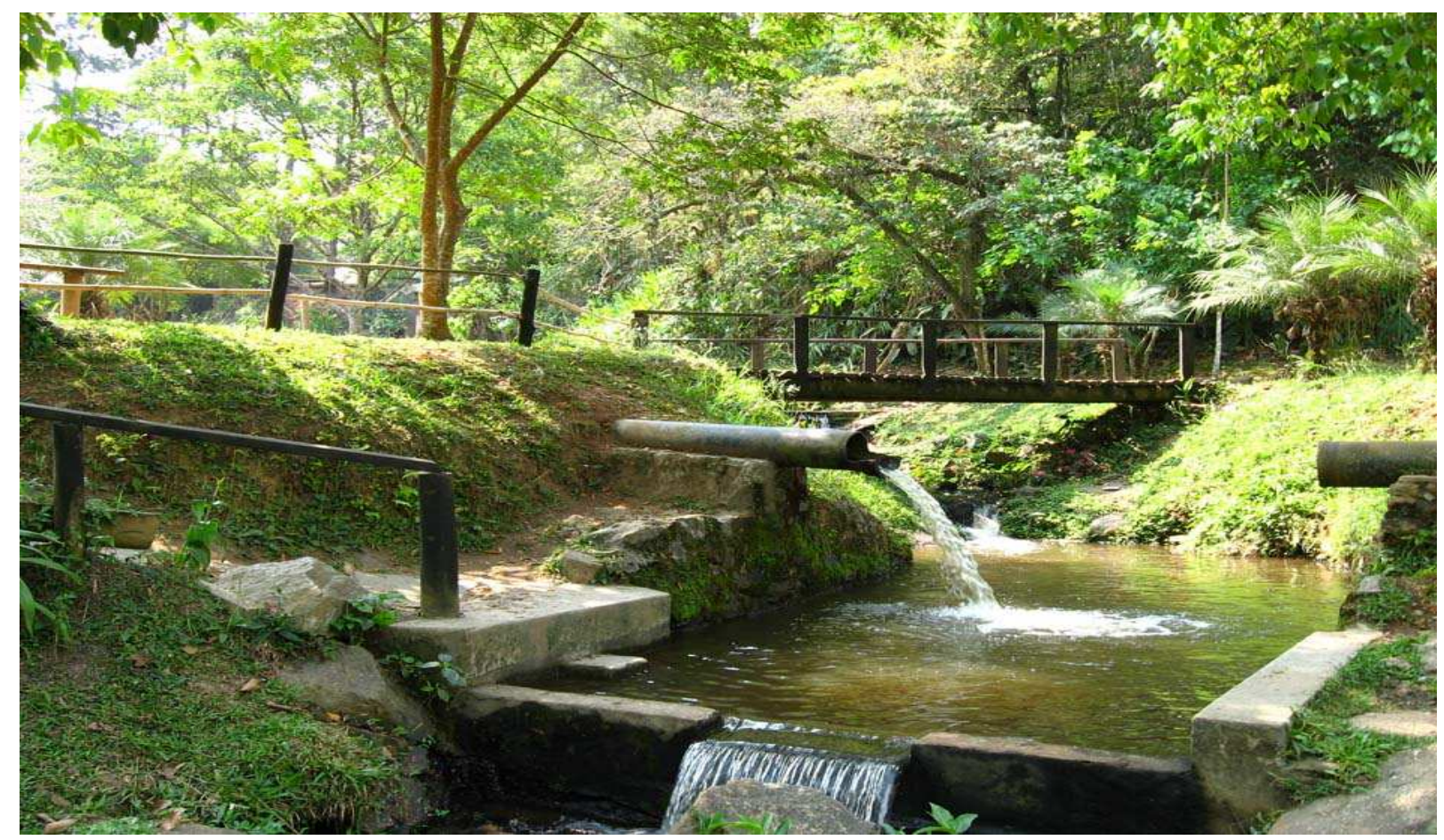

Foto de outubro de 2007, onde se vê que a adutora, acima descrita, foi interrompida, servindo de ducha, para a área de lazer do Núcleo do Engordador. 


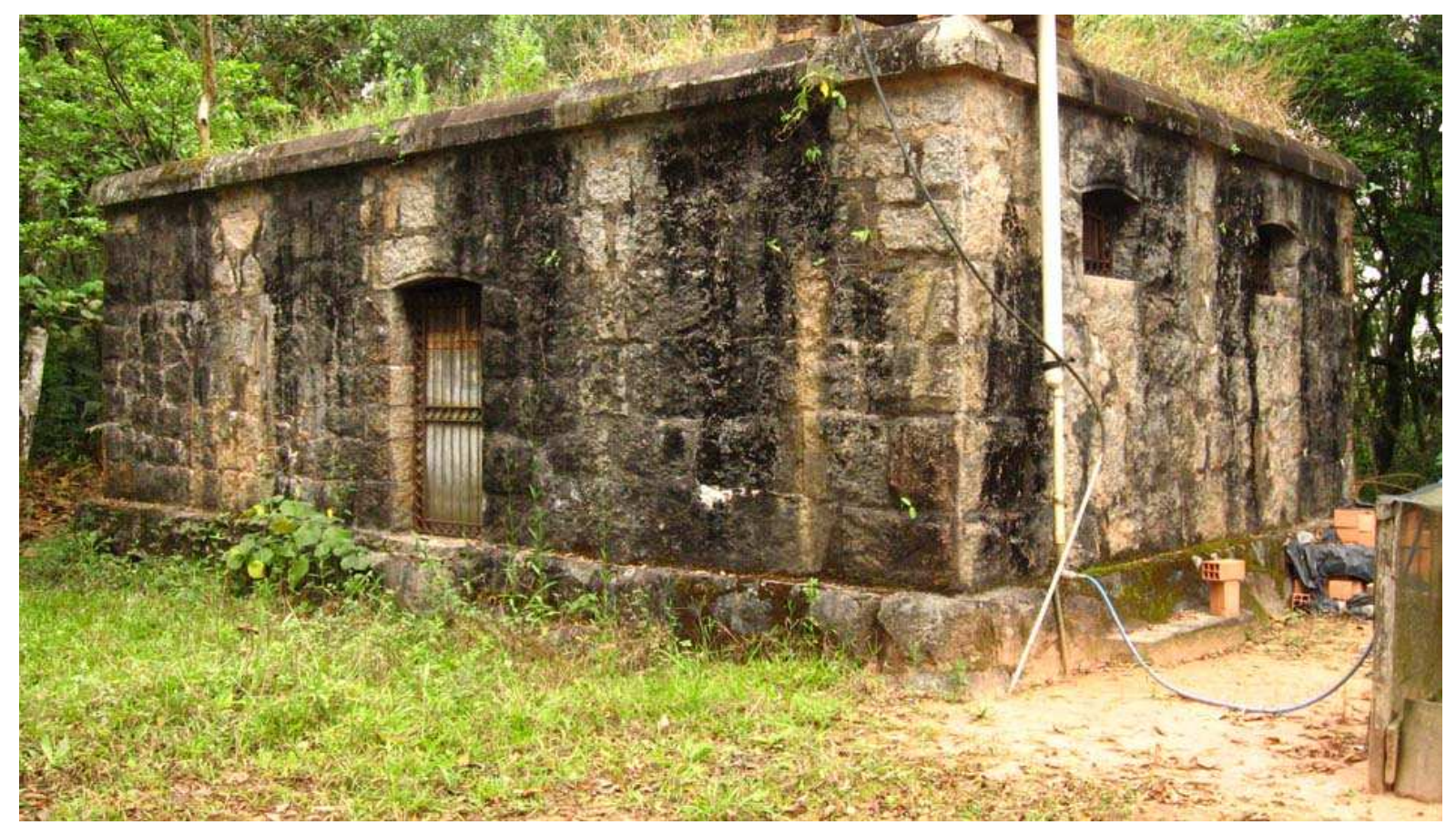

Foto de outubro de 2007 - Caixa d'água do Gonçalves.

Desta caixa seguiam as águas do Engordador, diretamente para 0 reservatório da Avenida, e para a represa do Cassununga, que fazia parte do antigo sistema implantado no século XIX.

Atualmente desativada, é utilizada como depósito de materiais, sendo essa solução adotada pela administração do Parque Estadual da Cantareira, para impedir que seja invadida, como já havia ocorrido no passado. 


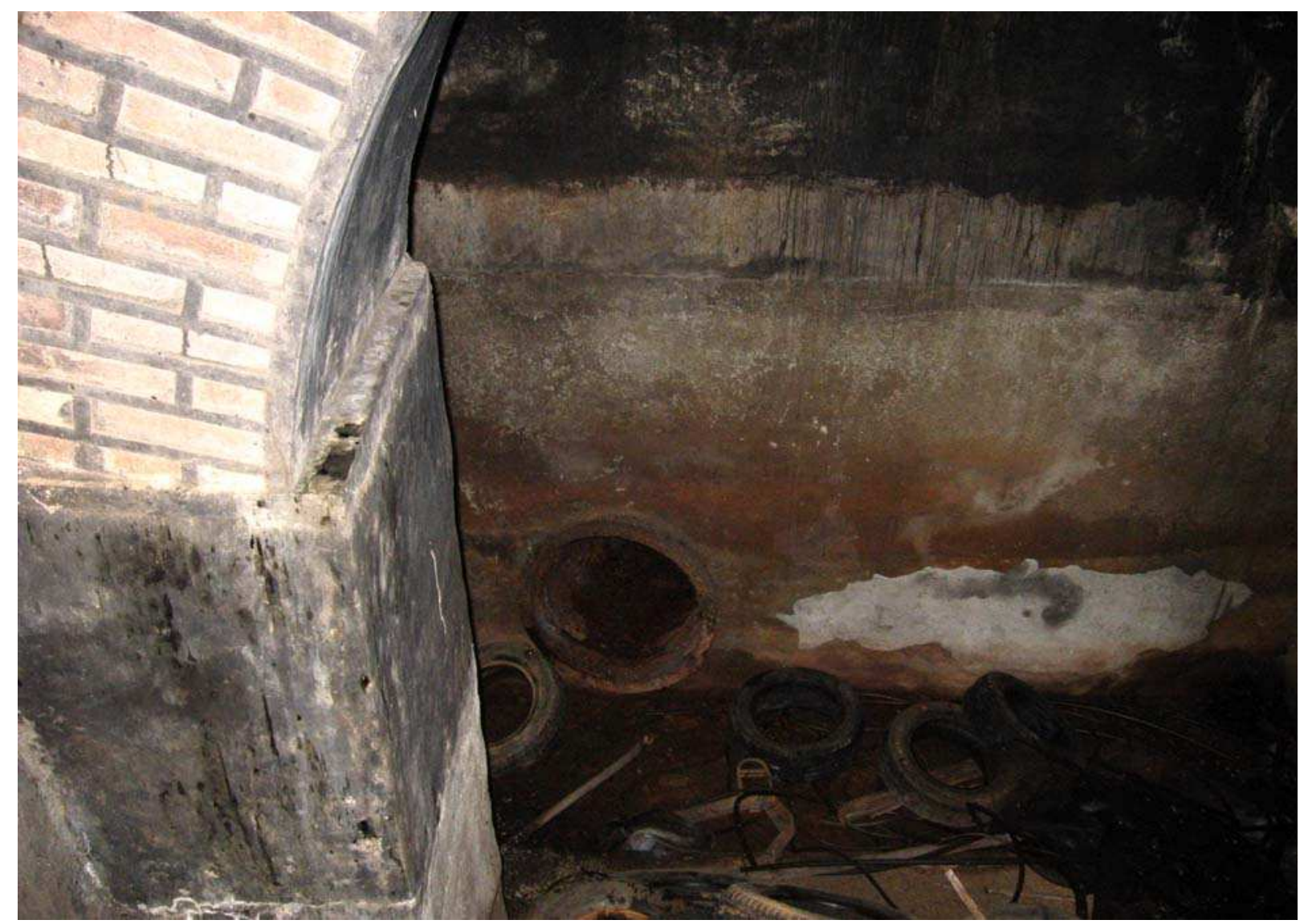

Foto de outubro de 2007. Vista interna de um dos compartimentos da Caixa do Gonçalves, com materiais depositados.

\subsection{GUARAÚ - Antecedentes históricos}

Situada no vale do Guaraú, fornecia 5.000 .000 de litros diários ao reservatório da Consolação. Projetada pelo engenheiro João Duarte Junior ${ }^{120}$, custou aos cofres públicos a quantia de 130:000\$000. As duas obras, do Engordador e Guaraú, tiveram seus custos elevados em 300:000\$000, devido aos problemas de caráter extraordinário, que ocorreram durante sua execução.

${ }^{120}$ Relatório da Secretaria da Agricultura, Commercio e Obras Publicas do Estado de São Paulo de 1905, apresentado ao Presidente do Estado pelo Secretário da Agricultura. São Paulo, Typographia Brasil de Rothschild \& Co., 1906, p. 227. 


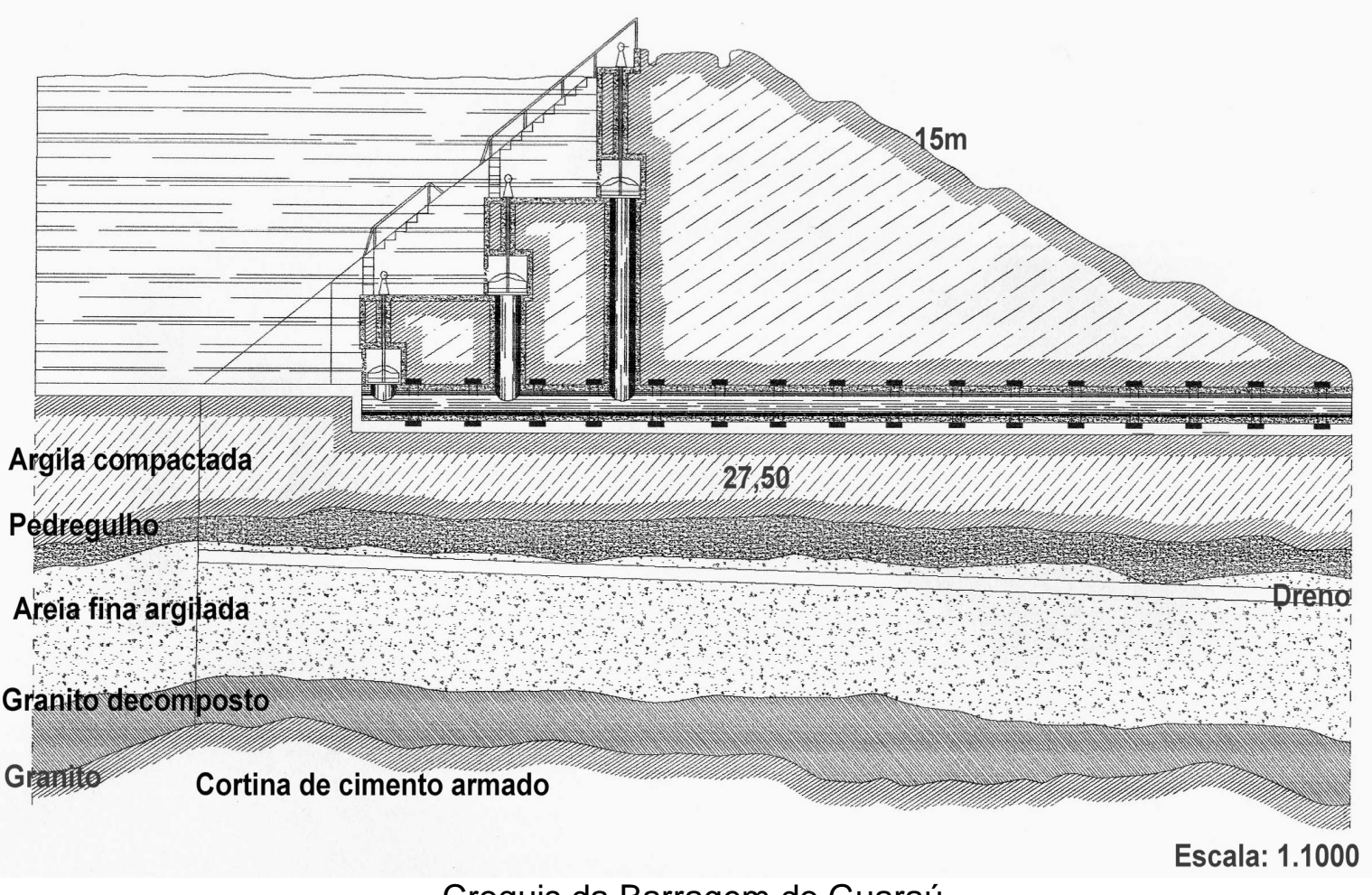

Croquis da Barragem do Guaraú.

O córrego do Guaraú dispunha de uma ante-represa, de onde partia uma linha de 200 mm de diâmetro, que desaguava em uma caixa de saída, através de um conduto de $600 \mathrm{~mm}$, para que as águas pudessem ser levadas à caixa de decantação para serem purificadas e, em seguida, jogadas na represa grande.

A exemplo do Engordador, foi adotado o sistema de barragem de terra, do tipo francês, e destinava-se a completar a vazão dos encanamentos da zona média, que apresentava um desfalque de 10 milhões de litros por dia. Segundo os técnicos, tendo em vista o bom resultado da análise das terras existentes nas proximidades do local da obra, prescindiu-se do emprego da cal na construção da barragem. Com 15 metros de altura, tinha a capacidade de retenção avaliada em $500.000 \mathrm{~m}^{3}$. 


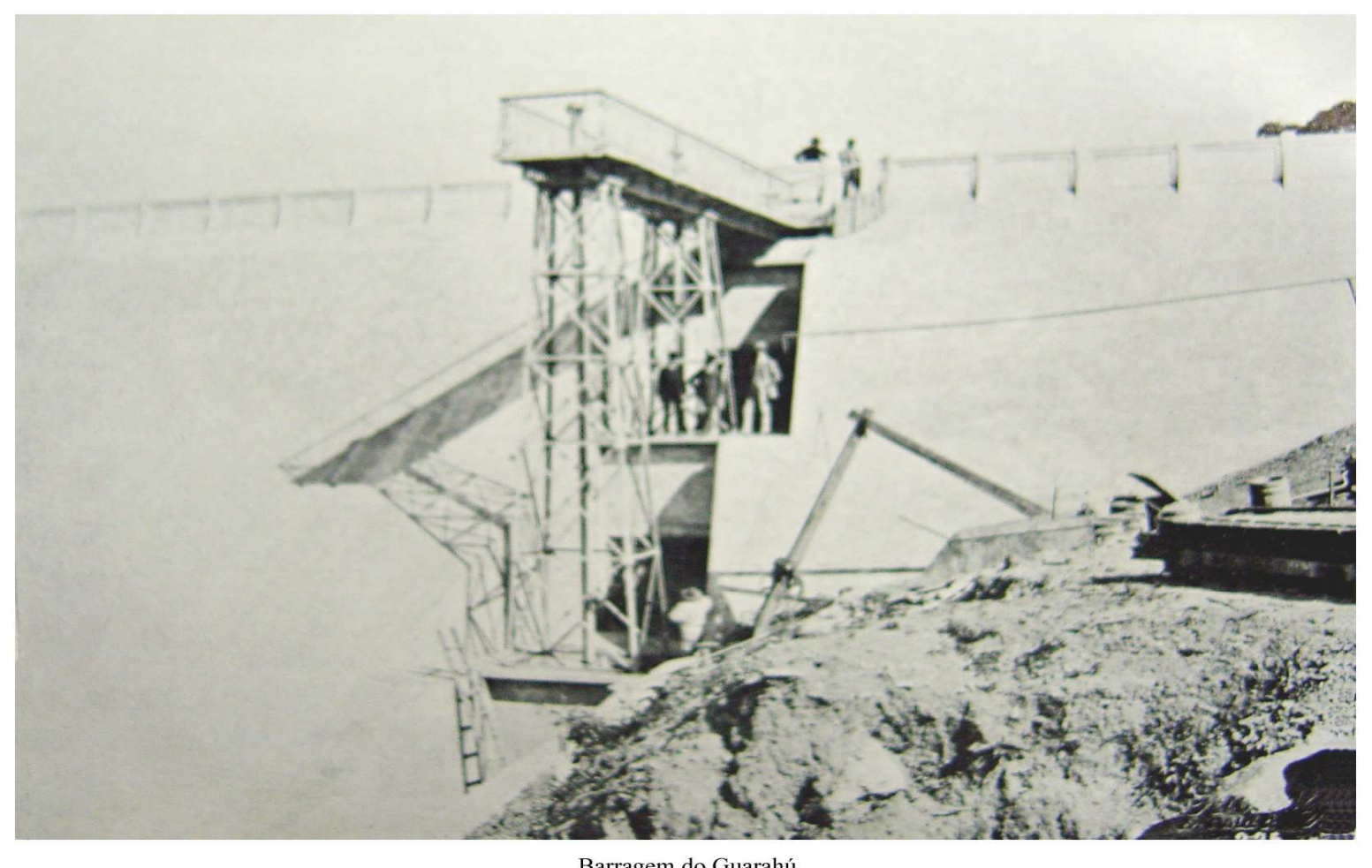

Barragem do Guaraú, foto do relatório da R.A.E, $1907^{121}$

$\mathrm{Na}$ tentativa de evitar infiltrações, os engenheiros também adotaram como revestimento do talude a montante, uma chapa contínua de cimento armado, que cobria toda a superfície exposta às águas, e ainda descia pela linha de intersecção do talude com o terreno até encontrar a rocha primitiva, ou seja, uma camada absolutamente impermeável. Segundo os relatórios da época, o emprego do cimento armado, constituía-se em um grande avanço, pois se tratava de um material que estava revolucionando a arte de construir, e era de aplicação recente ${ }^{122}$.

Segundo o projeto, no Guaraú, a tomada d'água era feita no próprio corpo da barragem, e não no eixo, como no Engordador, mas um pouco mais sobre a encosta, onde o terreno para a fundação era compacto e resistente.

\footnotetext{
${ }^{121}$ Relatório da Repartição de Águas e Esgotos de São Paulo, de 1907/1908, envidado ao Secretário da Agricultura, pelo Diretor, Typographia Brazil de Rothschild \& Co., São Paulo, 1909.

${ }^{122}$ Relatórios da Secretaria da Agricultura de 1903 a 1906.
} 


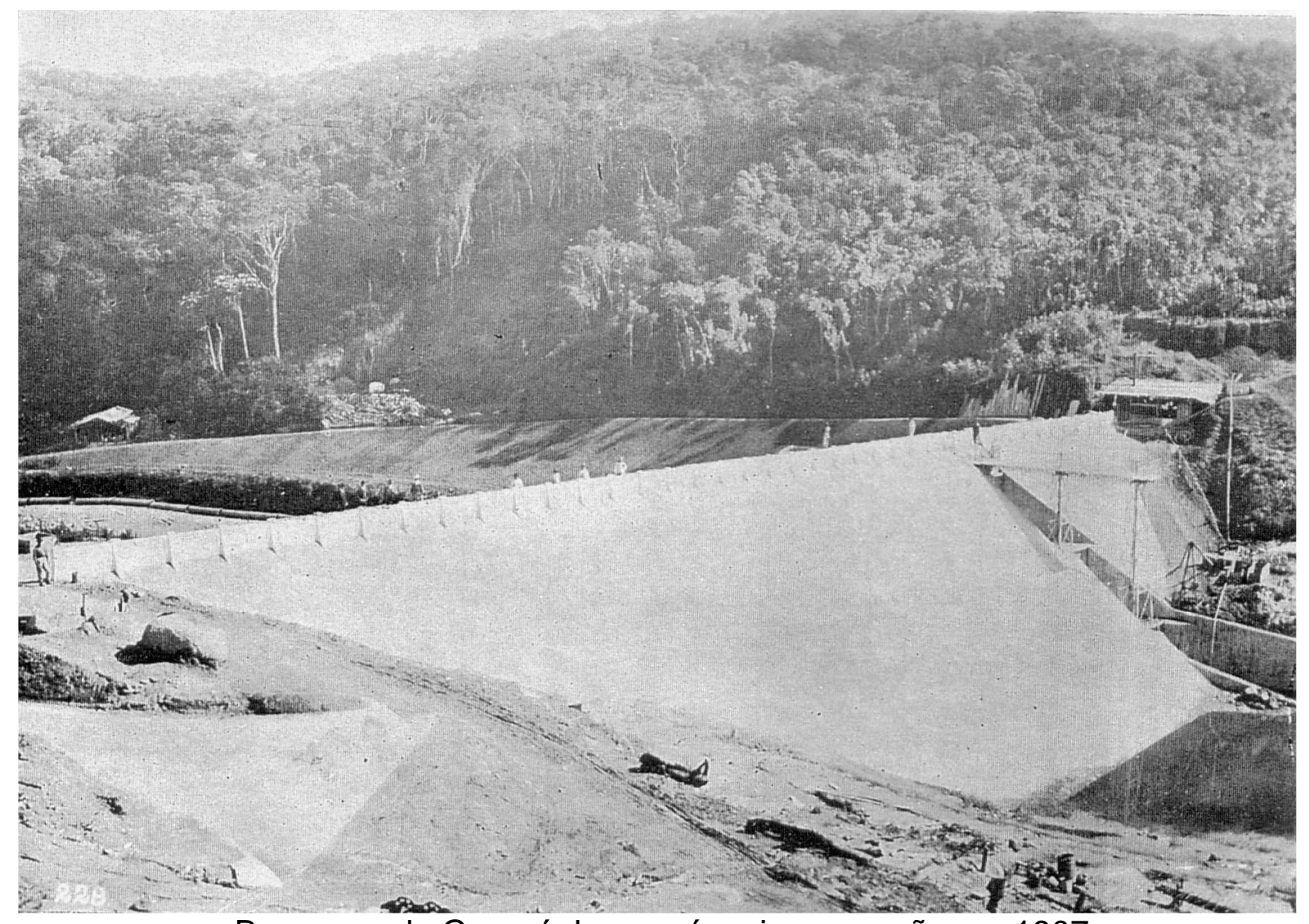

Barragem do Guaraú, logo após a inauguração em 1907

Havia também um aqueduto geral para o escoamento das águas e três tubos verticais que saiam das tomadas d'água e com ele se comunicavam. Os tubos verticais de construção mais fácil, segundo os relatórios da época, apresentavam a vantagem de permitirem o emprego de comportas cilíndricas horizontais usadas com enorme sucesso nas eclusas. Estas se compõem de um cilindro que se move dentro de outro fixo; o cilindro móvel é coberto e sustenta um tubo que protege a haste de elevação da comporta. A pressão vertical da água é suportada pelo cilindro fixo, de maneira que a parte móvel só recebe pressões laterais que fazem o equilíbrio. $O$ esforço para elevar uma comporta deste tipo seria o mesmo necessário para levantar seu próprio peso, de aproximadamente quatrocentos quilos. Por meio de um aparelho de manobra, o esforço se reduz a sete quilos, durando a operação de abertura da comporta apenas alguns segundos.

Embora seu emprego para a época, (1905/1906), fosse novo, De Mas aconselhava seu uso: 
"Mais, à défaut de ces vannes spéciales, il semble qu'on aurait pu avoir recours aux vannes cylindriques basses dont nous avons parlé dans um autre volume. Ces dernières ont fait leurs preuves et, bien qu'elles naient pás encore été employées, a notre connaissance, pour les reservoirs, elles y trouveraient une application naturelle". ${ }^{123}$ (MAS, 1904)

Do projeto do Guaraú faziam parte: um vertedouro de $4 \mathrm{~m}$ de largura, construído em um dos flancos do vale, destinado a dar escoamento às sobras da represa, além de outras obras de suporte tais como valas de proteção em torno das bacias, drenos estabelecidos na calçada do coroamento, que foi revestida de paralelepípedos, e em toda a extensão do talude de jusante: parapeitos, escadas de acesso e outros.

Foi inaugurada em setembro de $1907 .^{124}$

\footnotetext{
${ }^{123}$ MAS, François Barlatier De. Canaux. Encyclopedie des Travaux Publics, Ed. Beranger, Paris, 1904, p.404.

${ }_{124}$ Relatório da Repartição de Águas e Esgotos de São Paulo, de 1907, apresentado ao Secretário de Agricultura, pelo Diretor, Typographia Brazil-Rothschild \& Co., São Paulo, 1908, p.91.
} 


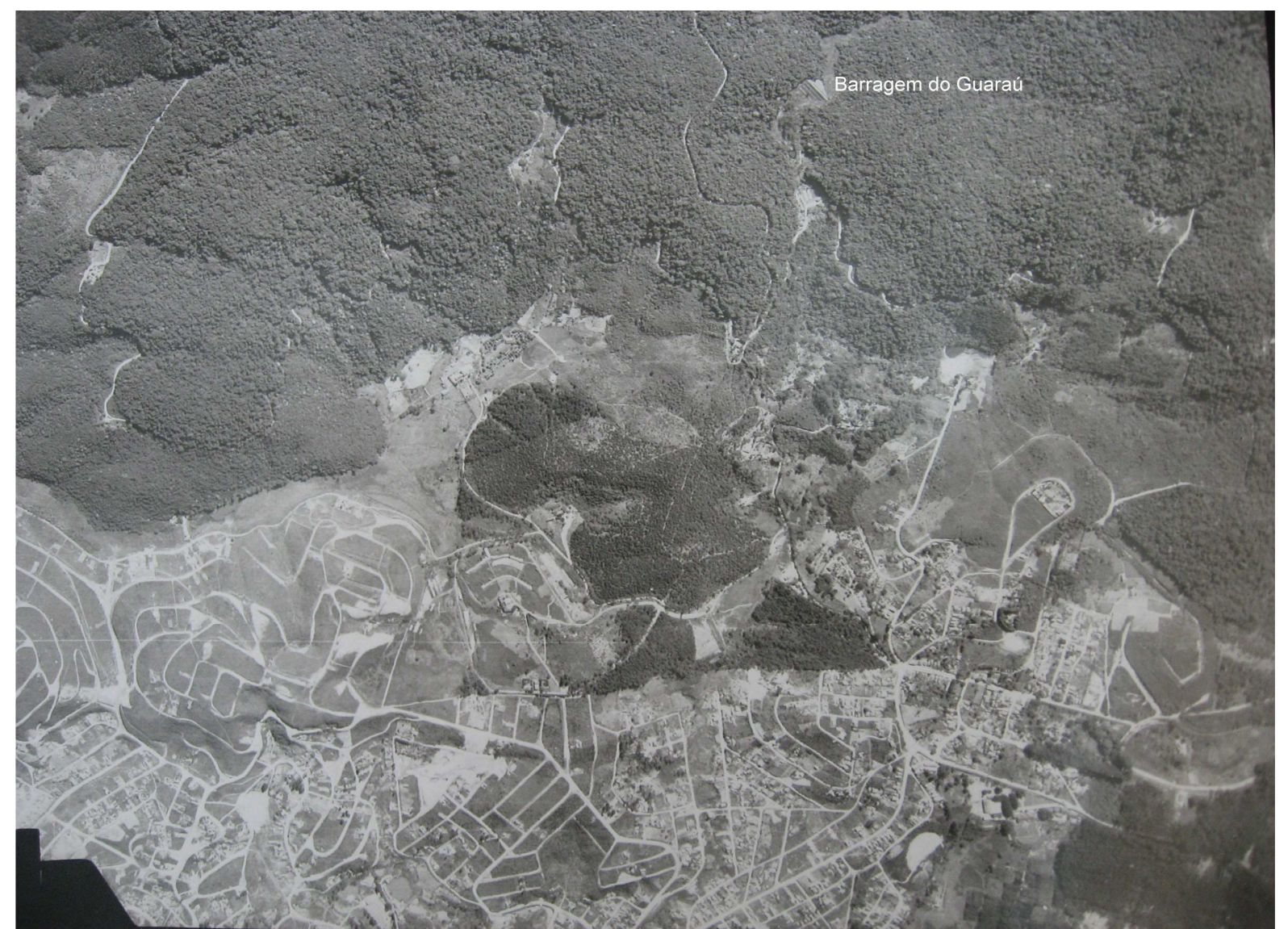

Foto aérea de 1966, acervo da SABESP.

Em destaque na foto, local onde se encontrava a represa do Guaraú, um pouco antes do início das obras da atual Estação de Tratamento do Guaraú. (ETA GUARAÚ). Pode-se observar que o lago artificial já estava completamente esvaziado. 


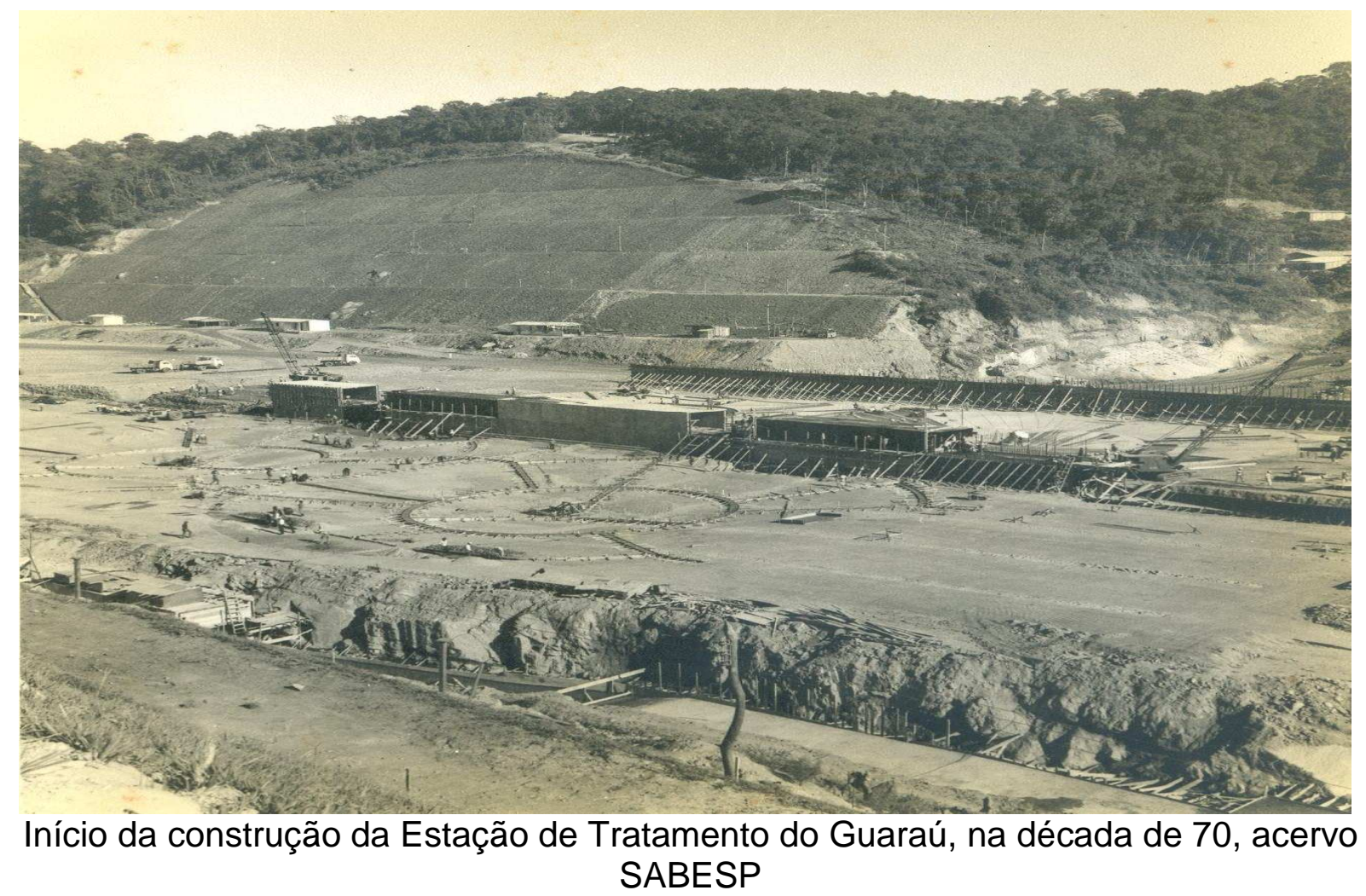

Na década de sessenta foi construída a E.T.A. Guaraú, com uma capacidade de tratamento de $33 \mathrm{~m}^{3}$ de água por segundo. Para a construção dessa obra, foi necessário o rebaixamento do solo em aproximadamente 60 metros. Ao fundo da foto, pode-se observar o corte efetuado no morro, onde se encontrava a represa do Guaraú, inaugurada em 1908. 


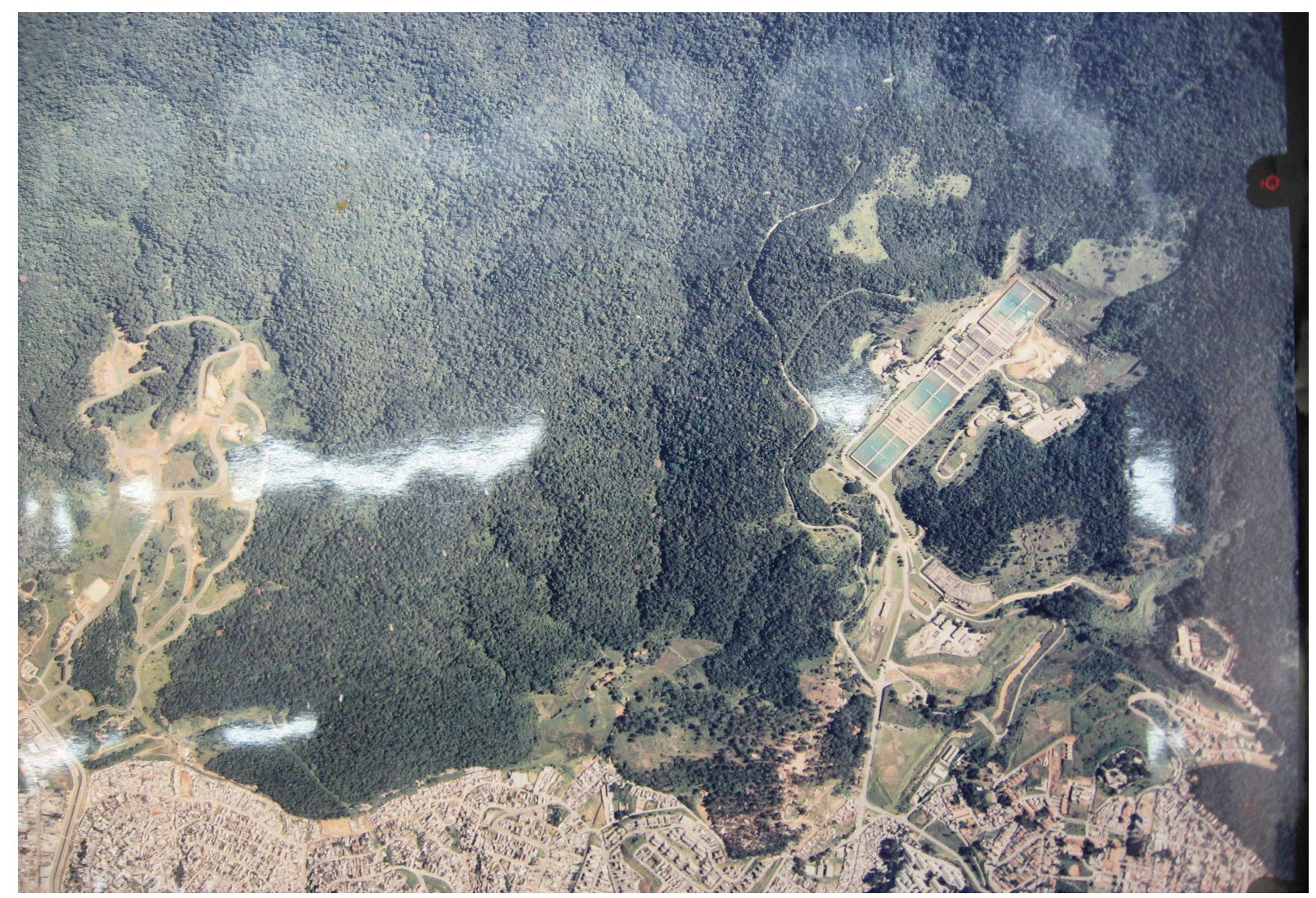

Foto aérea de 1974, logo após a inauguração da estação de tratamento do Guaraú.Acervo SABESP

\subsubsection{Pesquisa de Campo do Guaraú}

Em setembro de 2007, com o apoio da SABESP, o trabalho de campo consistiu em identificar-se o local da antiga represa do Guaraú e seu clarificador.

Sua posição geográfica, ficava a S 2326'20.03”, e W 46³8'51.15", U.T.M. 358317/7426799, e a uma altitude de $823 \mathrm{~m}$.

O complexo da antiga represa foi completamente destruído, sem deixar vestígios. 


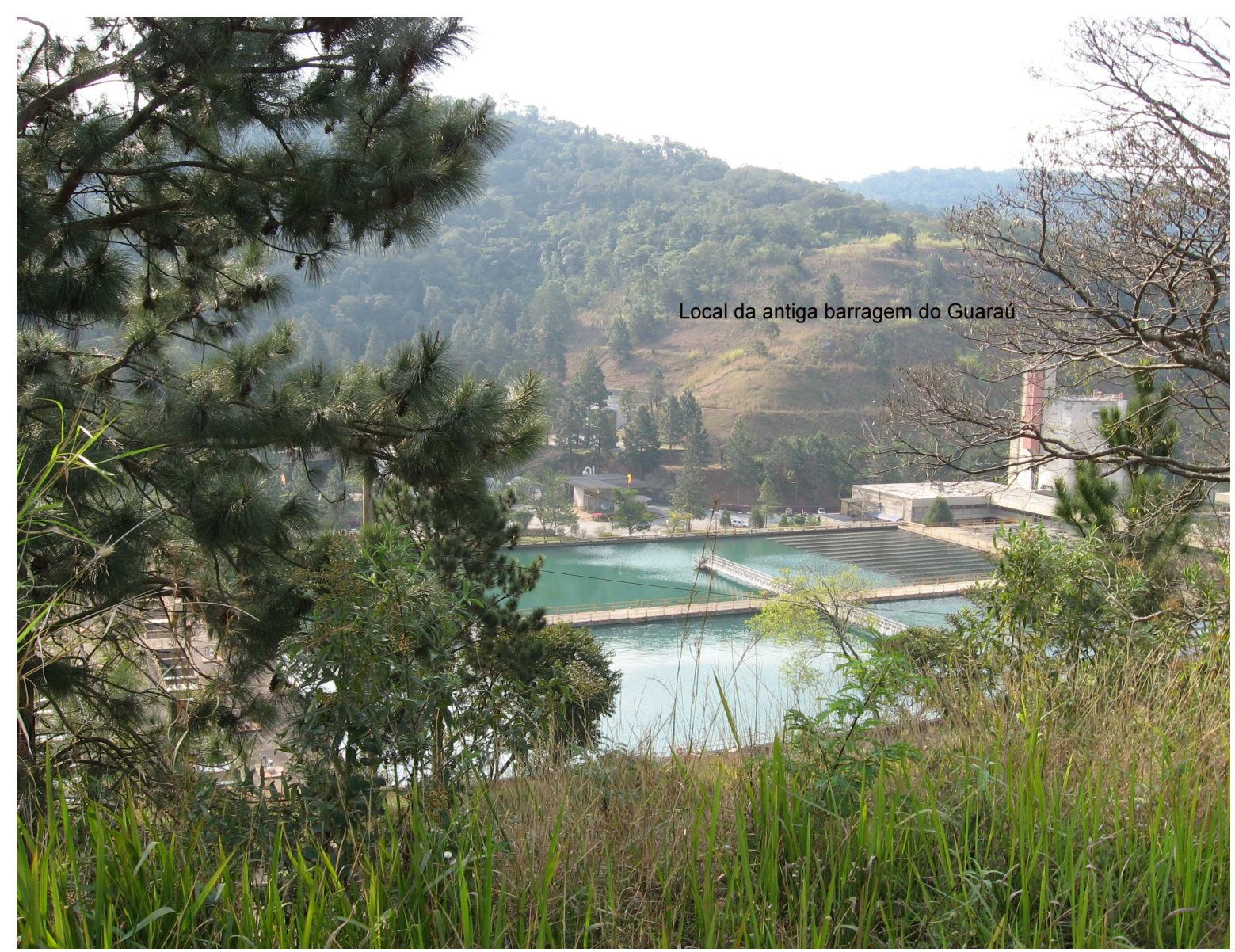

Local da antiga barragem - Foto tirada em setembro de 2007

Foram feitos estudos nos primeiros anos de 1904, para a captação do rio Guaraú, considerado um curso d'água menos exposto à contaminação. 


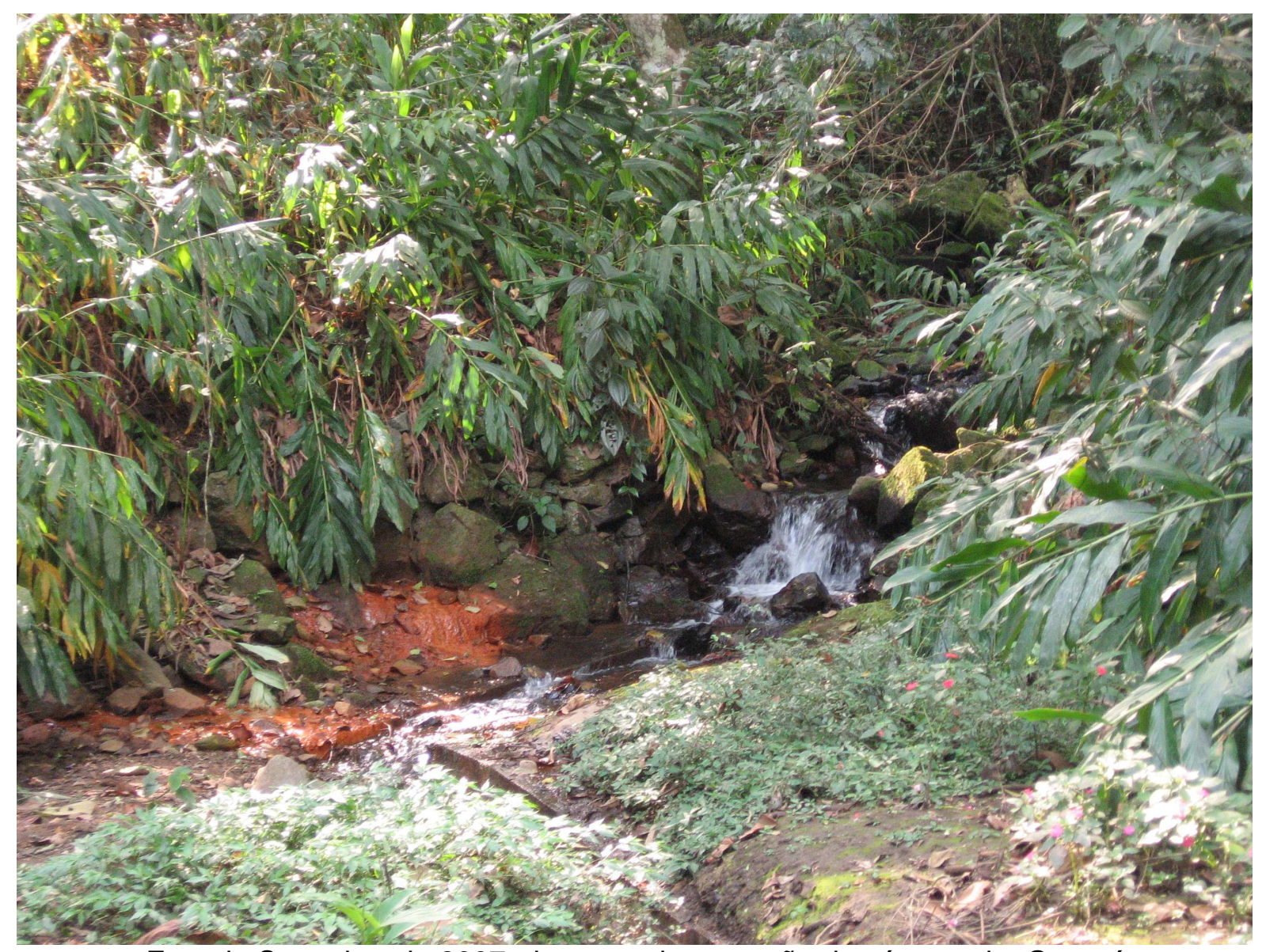

Foto de Setembro de 2007, do ponto de captação do córrego do Guaraú.

Seguindo o pequeno duto, que corria a céu aberto, aduzindo as águas da nascente do córrego do Guaraú, chega-se à pequena barragem de captação. 


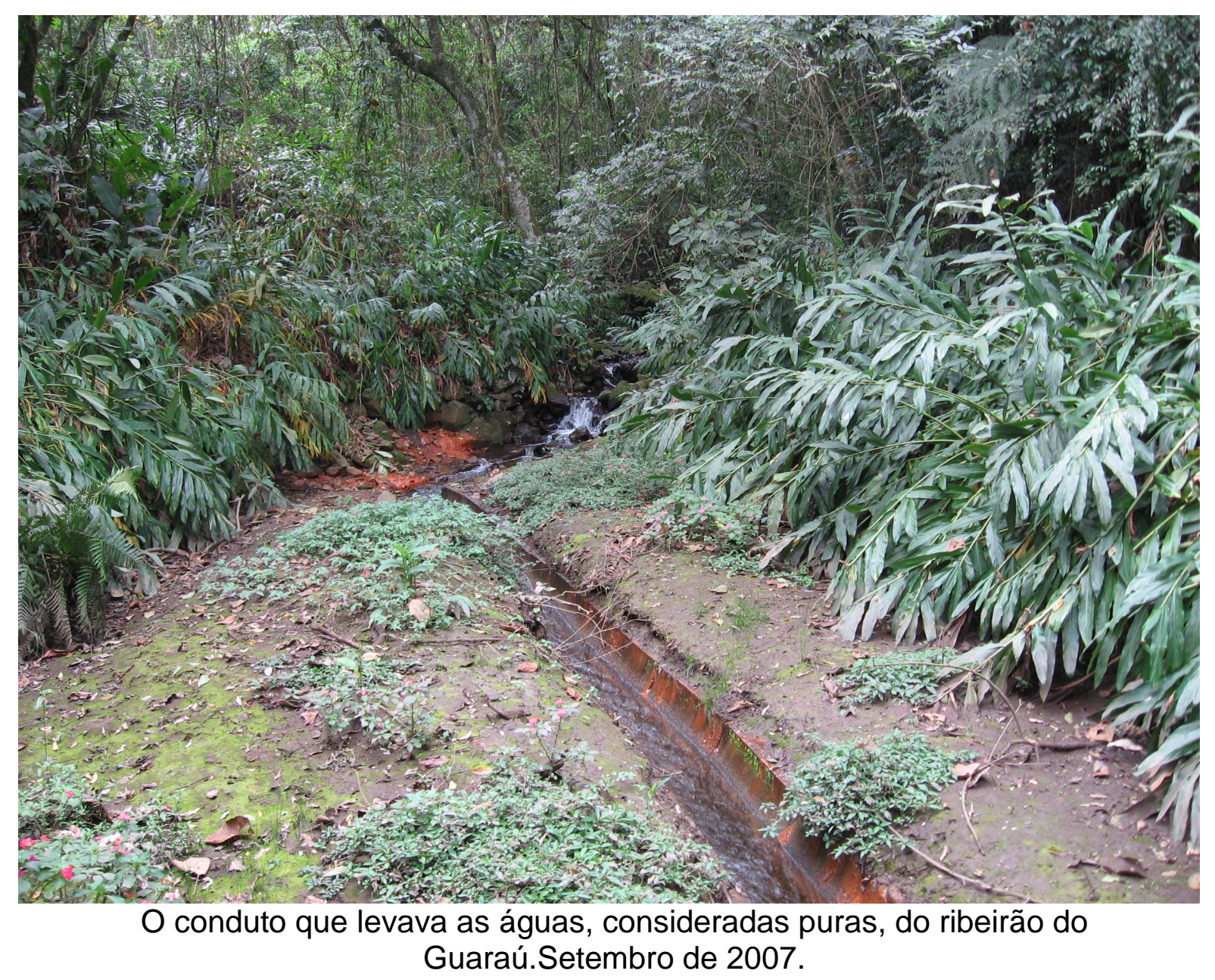




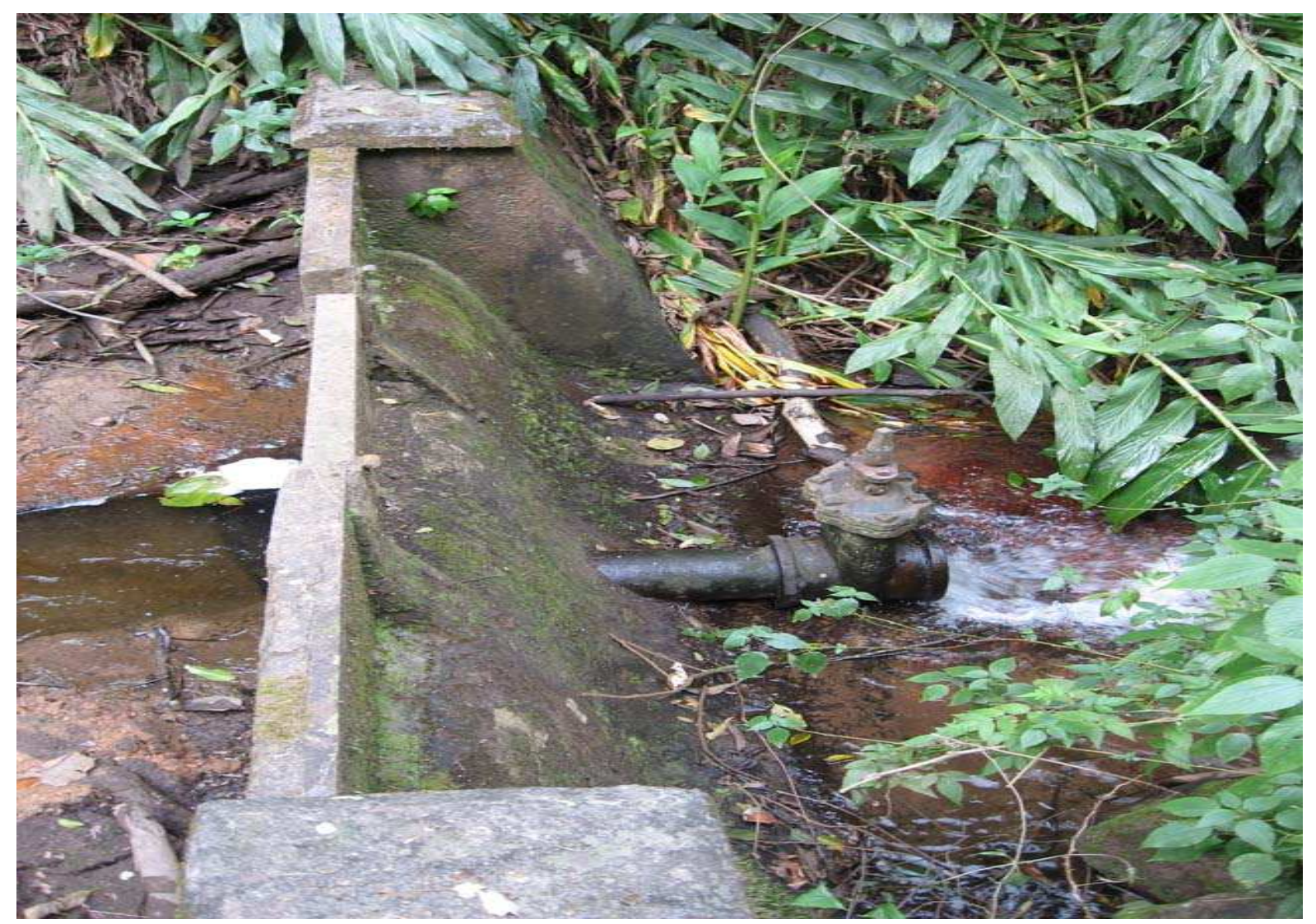

Ante-represa, do Ribeirão do Guaraú. Setembro de 2007

Esta pequena represa fazia parte do sistema de captação do Guaraú, antes de ser construída a maior com capacidade de $500.000 \mathrm{~m}^{3}$. Segundo a documentação da época, da ante-represa partia uma linha de $200 \mathrm{~mm}$, que desaguava na caixa de saída, e através de um conduto de $600 \mathrm{~mm}$, seguia para a distribuição na cidade.

Porém, como pode ser observado, não existem mais sinais desses sistemas, os vestígios se resumem à pequena barragem, ao registro, e ao encanamento que foi desconectado.

A barragem do Cabuçu, ${ }^{125}$ formadora do lago artificial do Cabuçu, mede 15 metros de altura e obedece ao perfil prático do engenheiro norte americano Wegmann ${ }^{126}$ e foi construída, diferentemente das outras duas, inteiramente de concreto armado, obedecendo aos padrões dos mais modernos sistemas construtivos de barragens que se praticavam no mundo, quer em relação ao perfil de seus muros de contenção, quer em relação ao material empregado, como também

\footnotetext{
${ }^{125}$ Será tratada com mais detalhes no capítulo: Convergindo para a Arqueologia do Cabuçu.

${ }^{126}$ WEGMANN, Edward, C.E. The Design and Construction of Dams, Ed.John Wiley \& Sons, Nova York, 1908.
} 
pela aplicação pioneira do hipoclorito de sódio altamente eficaz no tratamento da água eliminado-a de substâncias tóxicas que alteravam seus caracteres orgalonolépticos tornado-a imprópria ao consumo.

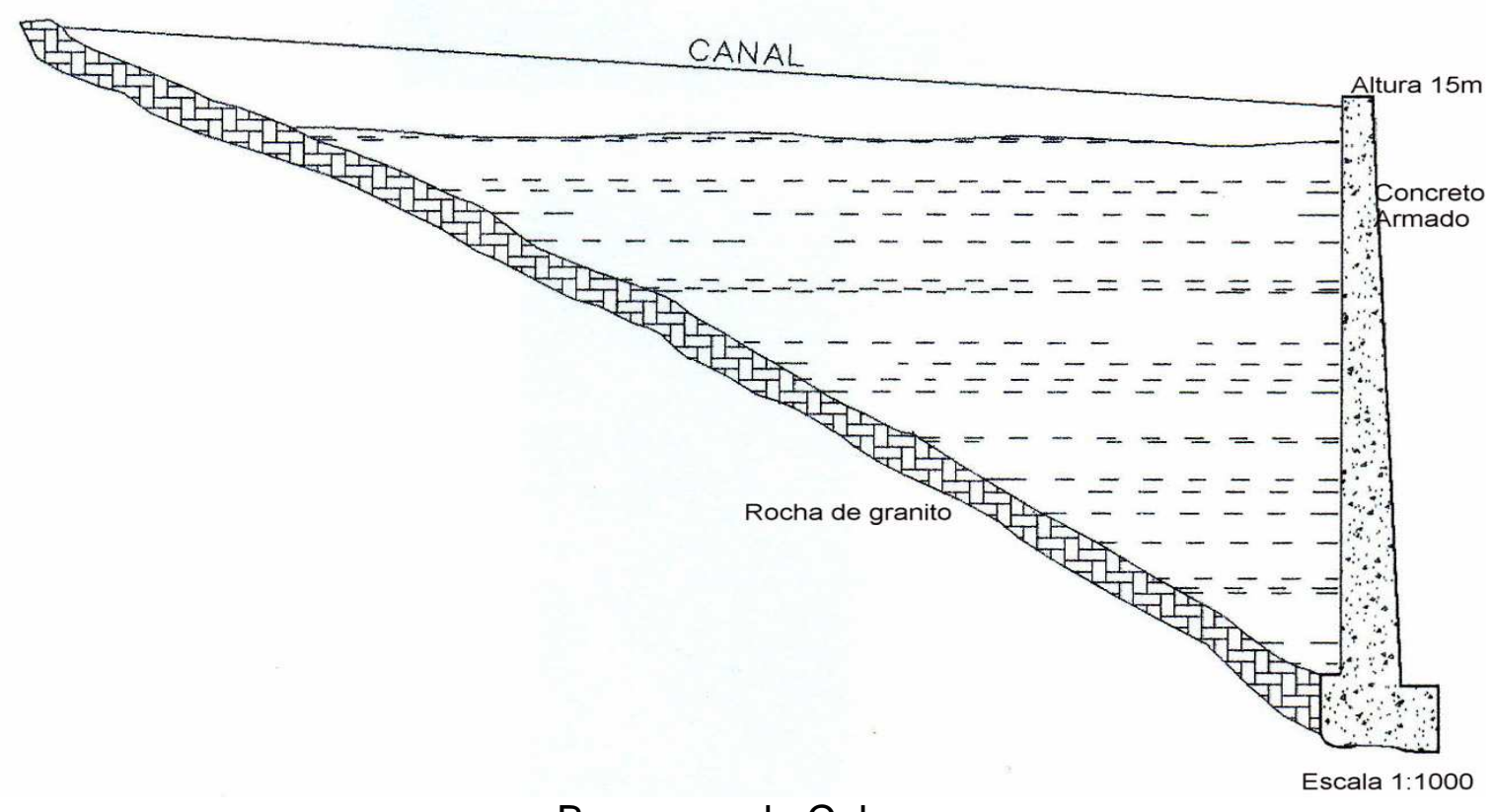

Barragem do Cabuçu

\section{7 Águas Claras}

Na formação dos lagos artificiais, se o objetivo precípuo era o de satisfazer uma demanda cada vez mais urgente por água, talvez fosse impossível atingi-lo em uma cidade em franca expansão, como se depreende dos números de prédios que foram construídos na primeira década do século XX: 1091 prédios em 1906, 1237 em 1907, 1621em 1908, 2.395 em 1909 e 3.231 em 1910. ${ }^{127}$

Esse desenvolvimento crescente da população paulistana preocupava o governo no que dizia respeito à necessidade de se melhorarem cada vez mais as condições do saneamento da cidade, aumentanto-se consideravelmente o volume de água disponível e assegurando-se o controle de sua melhora qualitativa, o que garantia sua potabilidade e impedia a propagação de doenças e até óbitos que as águas contaminadas pudessem ocasionar.

\footnotetext{
${ }^{127}$ Mensagem enviada ao Congresso Legislativo do Estado de São Paulo, a 14 de julho de 1911, pelo Presidente do Estado, São Paulo, 1911, p.37.
} 
Para tal qualidade de água, foram construídos, em 1908, clarificadores, a fim de remover partículas sólidas suspensas que provocavam a turbidez das águas, apenas nos dois reservatórios, Guaraú e Cabuçu, que, malgrado os esforços de seus técnicos, mostraram-se insuficientes para o fim a que foram destinados que era o tratamento de suas águas, livres das impurezas nocivas à saúde dos paulistanos.

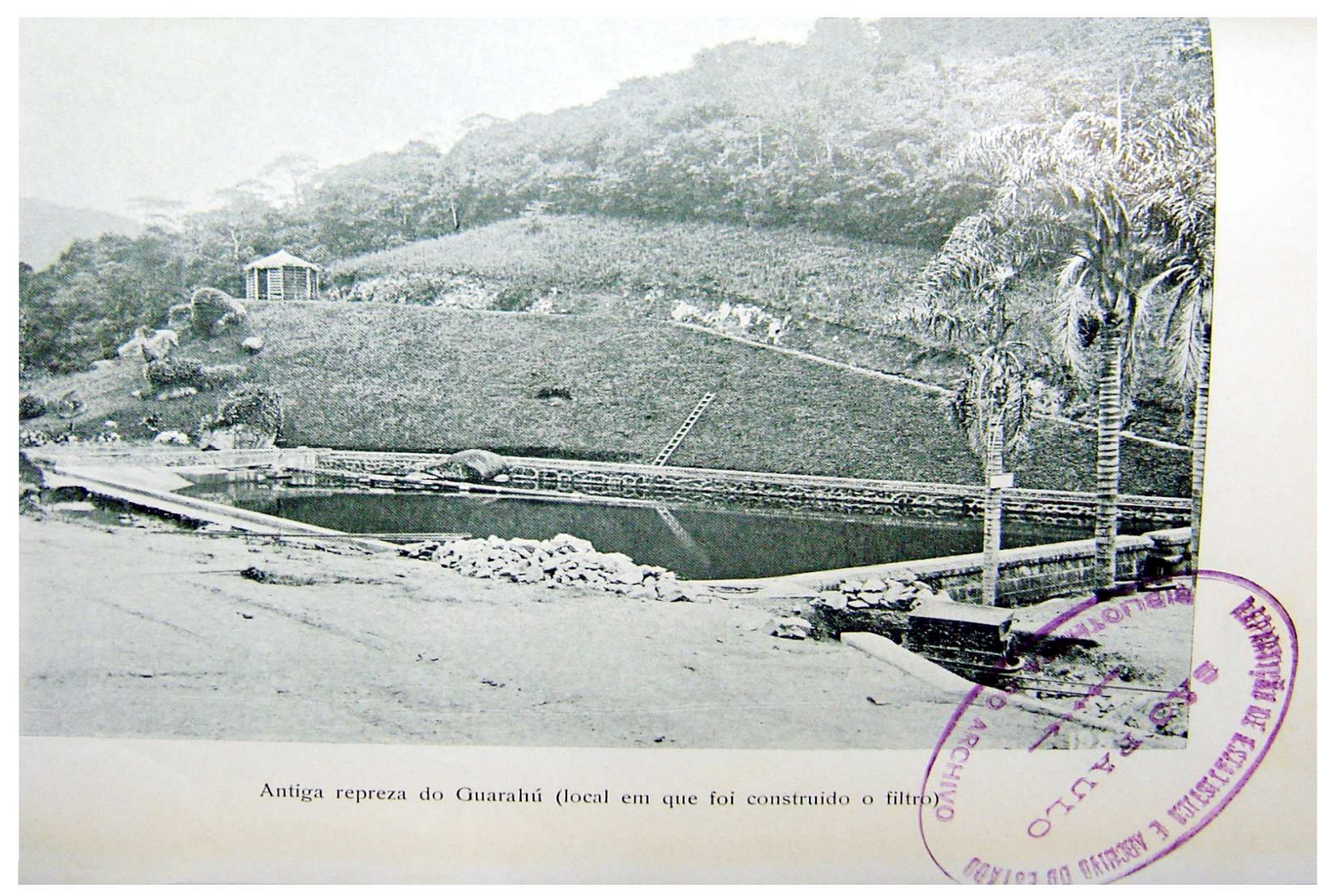

Local da construção do filtro da represa do Guaraú. Foto do Relatório da Repartição de Águas e Esgotos de São Paulo ${ }^{128}$

No decorrer de 1910, os lagos artificiais ainda não haviam contribuído para o abastecimento, em razão das dúvidas quanto à qualidade das águas, detectada através das análises químicas e bacteriológicas. Arthur Motta, Diretor da R.A.E. considerava ter havido uma melhora naqueles meses no Engordador, esperando que o mesmo acontecesse com os outros dois reservatórios, Guaraú e Cabuçu.

A repartição prosseguiu seus estudos, realizando metodicamente análises de potabilidade, e seu Diretor "julgou prudente não se effectuar despesa avultada com a

\footnotetext{
${ }^{128}$ Relatório da R.A.E. de 1907/1908, enviado a Secretário da Agricultura, pelo Diretor. Typographia Brazil - Rothschild \& Co., São Paulo, 1909.
} 
construcção de filtros de arêia ou qualquer outro tratamento efficaz, por não ser de necessidade immediata o approveitamento dessas aguas e ser preferivel a acção benefica do tempo, emquanto se colhem os necessarios subsidios para o estudo em questão". ${ }^{129}$

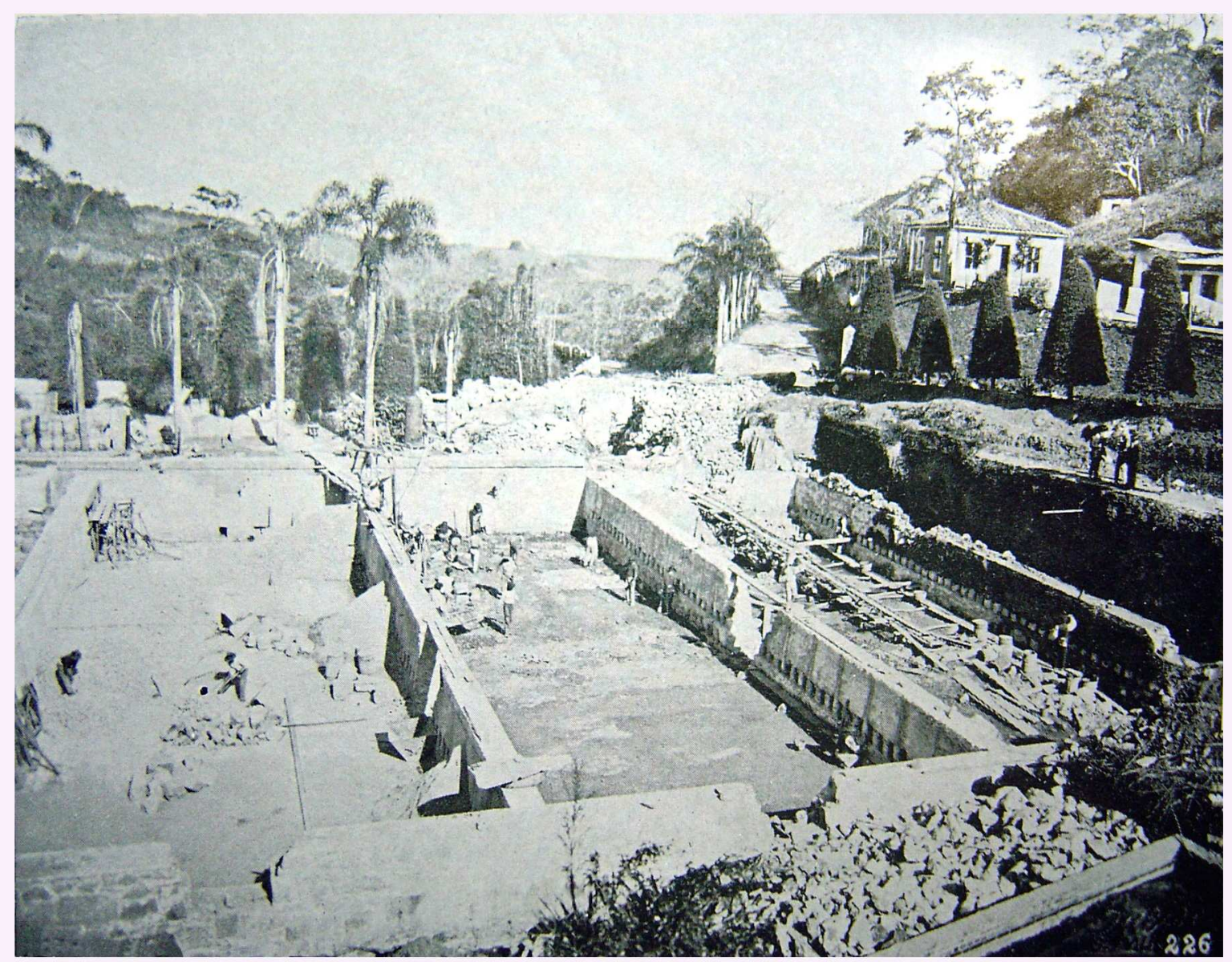

Construcção do clarificador do Guarahú

Foto da construção do clarificador do Guaraú. ${ }^{130}$

Entretanto, como esse benefício não acontecia, e o tempo passava, Arthur Motta, em Relatório da R.A.E. ao Secretário da Agricultura, justificava-se alegando que a falta de recursos tinham-no impedido de "organizar projetos para a Construcção de um filtro reservado ao tratamento das aguas do lago do Engordador

\footnotetext{
${ }^{129}$ Relatório dos Negócios da Agricultura, Comércio e Obras Públicas do Estado de São Paulo, apresentado ao Presidente do Estado, pelo Secretário da Agricultura, ano de 1907, Typographia Brazil de Rothschild \& Co., São Paulo, 1908, p.296.

${ }_{130}$ In relatório da Repartição de Águas e Esgotos de 1907/1908, enviado ao Secretário da Agricultura, pelo Diretor, Typographia Brazil - Rothschild \& Co, São Paulo, 1909.
} 
e para o estabelecimento de uma estação experimental comparativa, a jusante da barragem do Guarahú". 131

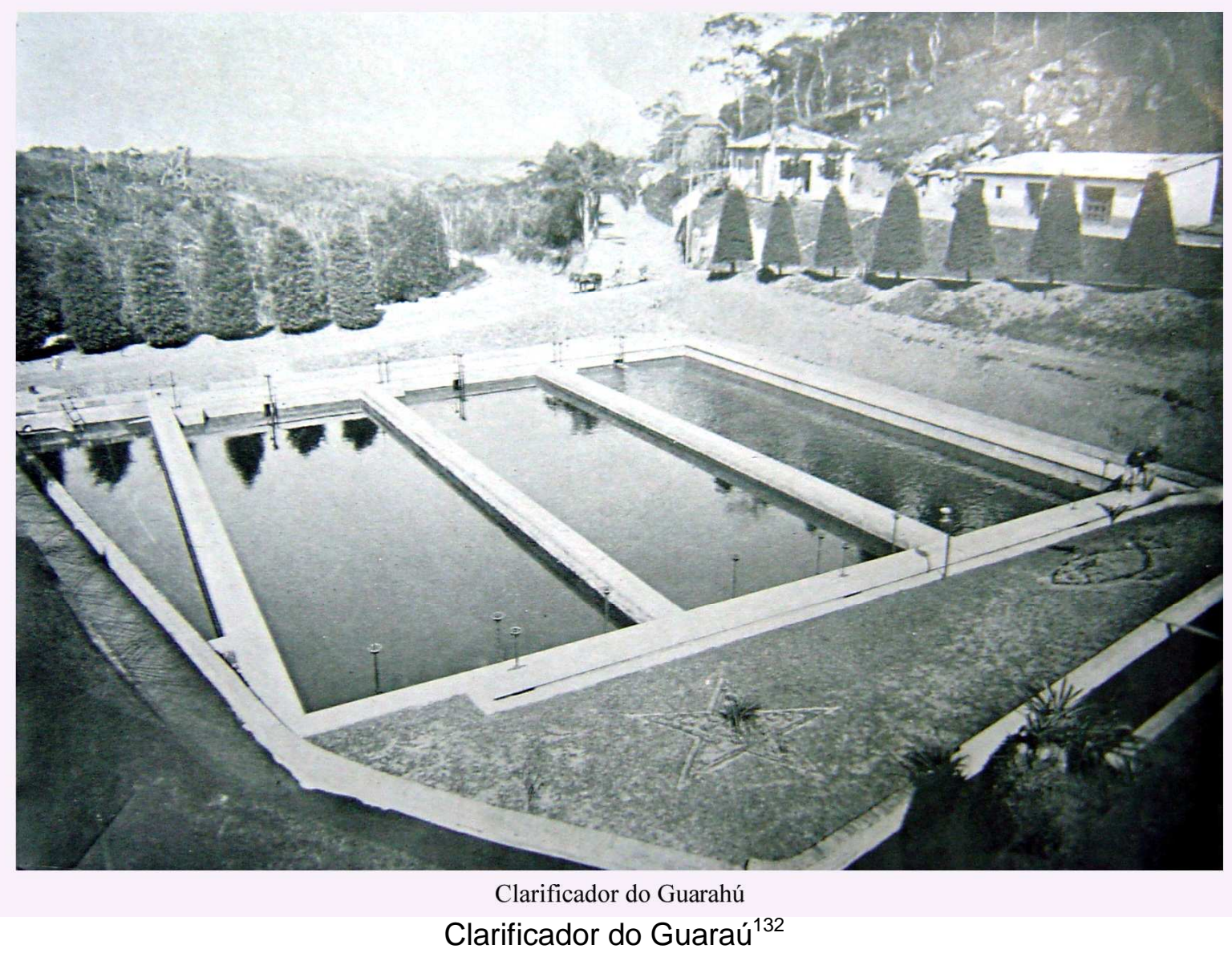

O filtro em questão, dos engenheiros Puech e Chabal, que tanto sucesso obtivera nos serviços da Compagnie des Eaux de la Banlienne de Paris e de outras cidades européias, consistiam em três ou quatro séries de corredores paralelos, sendo uma série separada da outra através de um areador em cascata. Os compartimentos, cujas superfícies eram de dimensões diferentes, da menor para a maior, continham também pedregulhos de tamanhos diversos do maior para 0 menor, portanto, inversamente proporcionais, e quando a água chegava à quarta série de filtração empregava-se areia grossa, em uma superfície filtrante aumentada, para que a água pudesse ser aerada, fazendo com que desaparecessem os

\footnotetext{
${ }^{131}$ Relatório da Repartição de Águas e Esgotos de São Paulo, de 1909, apresentado ao Secretário da Agricultura, Comércio e Obras Públicas, pelo Diretor, Ed. Casa Garraux, São Paul, 1910, p.24.

${ }_{132}^{1 n}$ Relatório da Repartição de Águas e Esgotos de São Paulo, de 1909, apresentado ao Secretário da Agricultura, Comércio e Obras Públicas, pelo Diretor, Ed. Casa Garraux, São Paulo, 1910.
} 
materiais oxidáveis, pela absorção de grande parte do oxigênio em dissolução na água.

Nestes primeiros anos do século $X X$, a comunidade científica se manifestava partidária da filtração lenta de areia, precedida de clarificadores e arejadores, conforme o sistema Puech-Chabal, por ser o que mais se aproximava da filtração natural das águas das fontes, proporcionando resultados satisfatórios do ponto de vista químico e bacteriológico o que dispensava a intervenção de substâncias estranhas à água como tratamentos químicos e processos de esterilização considerados muito modernos para a época e cujos efeitos no ser humano, a longo prazo, não haviam ainda sido testados.

O resultado das análises das três barragens, exposto nos relatórios da Secretaria da Agricultura e da Repartição de Águas e Esgotos, foi o de que suas águas não poderiam de imediato servir para o consumo da população, por terem se tornado impotáveis depois de acumuladas, em razão do desenvolvimento de microorganismos, e seu corretivo se impunha de acordo com o grau de alteração, sua natureza e resistência à purificação, segundo o ponto de vista dos higienistas da época.

De acordo com o laudo do Laboratório de Análises Clínicas ${ }^{133}$ "não obstante a média das analyses accusar uma melhoria das aguas, essa melhoria é, nos clarificadores, por demais insignificante, para se considerar semelhante systema de purificação de aguas digno de ser aconselhado. Se seu nome (dégronisseur) foi dado de accordo com a função a desempenhar, essa se limita simplesmente a reter as substâncias grosseiras, em suspensão na agua, e nunca eliminar aquillo que de menos grosseiro se nos depara no meio liquido - as bactérias."

A decantação nos grandes reservatórios é um dos meios mecânicos usados para melhorar a qualidade das águas, clarificando-as pela retenção das matérias em suspensão segundo a opinião de Debauve e Imbeaux, sobre saneamento: "Clarification par le repos: sédimentation et decantation. Ce procédé ne fat qu'imiter la nature, qai maintient claire l'eau dês grandes vasques em repos, comme les lacs". ${ }^{134}$ Tal procedimento faz com que a água armazenada em depósitos de grandes profundidades mantenha uma temperatura baixa e constante.

\footnotetext{
${ }^{133}$ In Relatório da Repartição de Águas e Esgotos de São Paulo, de 1909, apresentado ao Secretário da Agricultura Comércio e Obras Públicas pelo Diretor, Ed. Casa Garraux, São Paulo, 1910, p.34.

${ }^{134}$ DEBAUVE A. e IMBEAUX. E. L'álimentation en eau et l'assainissement des Villes. Ed. Bernard, Paris, 1902, 2 v, p.479 v 1.
} 
Em uma espécie de crítica velada ao Diretor da Comissão de Obras Novas, que, persistente em seu intento e alheio às opiniões contrárias, constrói os três reservatórios, Saturnino de Brito alegava que as barragens se distinguiam em função de sua utilidade, (armazenamento), técnica construtiva e sistemas de tratamento, e que convinha:

Distinguir as grandes barragens efetivamente úteis para regularisar o consumo de estiagem, das pequenas barragens, que apenas deveriam servir de aparelho decantador. Porque si se tirar destas, quando construidas sobre superficies naturais, um volume quase igual à sua capacidade, as ultimas camadas líquidas terão as impurezas concentradas e mais impuras se tornam pelo escorrer da água das margens lodosas postas a descoberto. ${ }^{135}$ (BRITO, 1943)

Quand on barre une vallée profonde et encaissée et qu'on y forme um véritable lac, on obtient une reserve importante ou l'eau se décante, acquiert une température presque constante, s'altère peu, pourvu que la profondeur ne descende nulle part au-dessous de 1,50 à 2 metres, et qui est considerée, particulièrement en Angleterre et aux Etats Unis, comme une excellente ressource pour l'alimentarion des villes. ${ }^{136}$ (BECHMANN,1909) ${ }^{137}$

A questão se resumia em saber o que deveria ser considerada "barragem de grande volume e a de pequeno volume". Plínio Queiroz, na defesa de Paes Leme, alegava tratar-se de uma distinção cujos contornos eram difíceis de se estabelecer e os grandes reservatórios à medida que suas águas fossem canalizadas para o consumo, notadamente em épocas de estiagem, passariam a ter reduzido seu tamanho, tornando o argumento de Saturnino de Brito, a seu ver, ilógico e não aceitável. $^{138}$

Segundo o engenheiro Queiroz, especialista no abastecimento de água em São Paulo, apenas estudos, análises e publicações de resultados durante anos poderiam fornecer parâmetros sobre a qualidade das águas do ponto de vista

\footnotetext{
${ }^{135}$ BRITO, Saturnino de. Obras Completas de Saturnino de Brito. Vol. III: Abastecimento de Água. Parte Geral, Tecnologia e Estatística, Ed. Imprensa Nacional, Rio de Janeiro, 1943, p.68.

${ }^{136}$ BECHMANN, Georges. In Relatório da Repartição de Águas e Esgotos de São Paulo, de 1907 e 1908, apresentado ao Secretário da Agricultura, pelo Diretor, Typographia Brazil-Rothschild \& Co.São Paulo, 1909, p.12.

${ }^{137}$ Chefe dos Serviços Técnicos do Saneamento de Paris e Professor da Escola de Pontes e Calçadas.

${ }_{138}$ QUEIROZ, Plínio. As Águas para São Paulo, Diário Nacional, 1927, In Revista Viação , no especial, Rio de Janeiro, 1928, p.116.
} 
químico e bacteriológico, por se tratarem sempre de águas armazenadas em clima tropical.

O debate também se estendia ao fato de se lançar mão ou não, para solucionar a grave crise da falta d'água, das barragens já construídas pela canadense Light and Power, que, autorizada a funcionar no Brasil pelo decreto 3.349, assinado pelo Presidente da Republica Campos Sales ${ }^{139}$, para explorar os serviços de transportes urbanos na capital paulista, havia construído, em Parnaíba, uma barragem no rio Tietê (Edgard de Sousa), inicialmente com alvenaria e posteriormente ampliada em concreto. Em 1901 entra em funcionamento a usina hidrelétrica, que precisava regularizar a vazão do Tietê para o funcionamento de suas turbinas. A solução encontrada foi a construção em 1906, em um dos afluentes do rio Pinheiros, de mais uma represa, a de Santo Amaro, hoje do Guarapiranga.

Das águas das grandes represas, como a de Santo Amaro, da Companhia Light \& Power, poderão tirar-se interessantes observações sobre a influencia do repouso na qualidade das aguas, tão apreciada, pelo seu valor como auxiliar da purificação na Inglaterra e em todas as localidades em que o mal das algas se não tenha feito notar". ${ }^{140}$ (BRITO, 1927)

Para ele, estas águas seriam provavelmente as mais apropriadas e econômicas para o abastecimento, por estarem situadas muito próximas à cidade, e por ser menor sua elevação mecânica. ${ }^{141}$

Outros, entretanto, consideravam que o problema residia na contrapartida entre os interesses da Light, em razão das somas vultosas que havia empregado em suas obras e a disposição em ceder a água de seus reservatórios faria com que a população paulistana ficasse, segundo Plínio Queiroz "com mais um serviço público dependendo dessa empresa estrangeira, que já é inquestionavelmente um Estado dentro do Estado". ${ }^{142}$

\footnotetext{
${ }^{139}$ Brasil Leis e Decretos. Decreto no 3349 de 17 de julho de 1899, onde o Poder Executivo concede autorização a The São Paulo Railway Light and Power Company, Limited para funcionar na República dos Estados Unidos do Brasil. Imprensa Nacional

${ }^{140}$ BRITO, Francisco S. de. O Problema da Água, in Viação Revista Technica Mensal Illustrada Rio de Janeiro, 1927, p.14.

${ }^{141}$ BRITO, Francisco S. Rodrigues de. O Problema da Água em São Paulo (Parecer). In Revista Viação, no especial, Rio de Janeiro, 1928, p.41.

${ }_{142}$ QUEIROZ, Plínio. As Águas para São Paulo. In Revista Viação, Rio de Janeiro, 1928, p.119.
} 
A esses fatores, os debatedores acrescentavam a impotabilidade das águas dessas represas, uma vez que foram armazenadas para fins industriais, sendo necessárias limpezas rigorosas, com o destocamento e a retirada de todo o humus da área inundada; sem esses procedimentos, a auto depuração levaria cerca de vinte anos, e o processo prejudicaria as atividades da Companhia que ficaria apenas com as águas armazenadas provenientes de precipitações chuvosas, o que seria uma temeridade em virtude das estiagens prolongadas que assolavam a cidade de tempos em tempos.

Foi exatamente o que aconteceu entre 1924 e 1925, quando novamente São Paulo se defronta com o drama de uma estiagem prolongada, com conseqüências desastrosas para o abastecimento.

Como forma de minimizar esse problema, Júlio Prestes, então Presidente do Estado de São Paulo, em 1928, determina a captação de cerca de 4 metros cúbicos de água por segundo, daquele lago de 196 milhões de metros cúbicos, a represa de Guarapiranga, cuja água foi considerada pura, apesar de sua proximidade com a cidade de São Paulo.

Este fato tornava menos premente a conclusão da adutora do Rio Claro, e o sistema Cotia que, iniciado em 1914, por muito tempo funcionara precariamente, e foi concluída em 1932, com o término da construção da barragem Pedro Beicht, regularizando a vazão do rio Cotia.

O ante projeto de adução do Cotia é de autoria do engenheiro Teodoro Ramos e data de finais do século XIX, em uma tentativa de expandir o sistema de abastecimento de água na capital que se restringia aos mananciais da Cantareira, aos ribeirões da Água Funda e as captações do Rio Tietê.

Foram, então, construídas duas represas, Cachoeira da Graça (1916) e Pedro Beicht (1929), com o objetivo de regularizar a vazão do Rio Cotia e canalizar a descarga e captação até a Estação de Tratamento do Morro Grande.

O Sistema Baixo Cotia entrou em operação após janeiro de 1963, com a inclusão das Barragens de Isoline Superior e Inferior.

Em 1954, diante da expansão da metrópole paulistana, foi extinta a RAE e criado o Departamento de Águas e Esgotos-DAE, responsável pela administração direta dos serviços de água e esgotos da Capital, Osasco, São Caetano, Santo André e São Bernardo do Campo. O DAE foi peça fundamental para o saneamento básico e o primeiro sinal de organização de uma região metropolitana. 
O Governo do Estado de São Paulo e a Cia. Light, em 1958, celebram um acordo em que a represa Guarapiranga passa a ser usada exclusivamente para abastecer a cidade; com a implantação da estação de tratamento do Alto da Boa Vista, a represa passou a fornecer 9,5 metros cúbicos por segundo, o que tornou obrigatória a elevação do seu nível de água.

Na década seguinte, com o crescimento do Parque Industrial e o aumento populacional da cidade, a demanda pela água gerou uma série de estudos e trabalhos na tentativa de solucionar o problema, e a alternativa vencedora foi a de procurar água na região das cabeceiras da bacia do rio Piracicaba, surgindo daí o Sistema Cantareira, o novo, substituindo o Sistema Cantareira Antigo que abasteceu parte da cidade de São Paulo até meados da década de 1970, quando entra em operação o Novo Sistema, um dos maiores conjuntos produtores de água no mundo.

Atualmente esse sistema é o maior fornecedor de água da Região Metropolitana de São Paulo, responsável por 52\% do abastecimento, com produção de 33 mil litros de água por segundo, retirados das represas formadas pelos rios: Jaguari-Jacareí, Cachoeira, Atibainha, formadores da bacia hidrográfica do rio Piracicaba, e a do Juqueri (Paiva Castro) na bacia do Alto Tietê.

As águas dos reservatórios Jaguari-Jacareí são aduzidas para o Cachoeira e dele para o Atibainha que, por sua vez tem suas águas canalizadas para a Bacia do rio Juqueri, e, deste último reservatório, elas são recalcadas pela elevatória Santa Inês, para a Estação de Tratamento do Guaraú , onde recebem tratamento, para em seguida serem distribuídas para a Região Metropolitana de São Paulo. ${ }^{143}$

\footnotetext{
${ }^{143}$ Outros sistemas abastecem São Paulo: Guarapiranga, (represa de Guarapiranga), segundo maior produtor de água, responsável por 13,5 mil litros de água por segundo. Alto Tietê, fomadores: o rio Tietê, Paraitinga, Biritiba, Jundiaí, Taiaçupeba-Mirim e Taiaçupeba-Açu, fornece 7,8 mil litros de água. Rio Grande, braço da represa Billings, abastece os municípios do ABC paulista com 4,2 mil litros por segundo. Rio Claro, colabora com 3,9 mil litros e atende um milhão de pessoas. Alto Cotia, represa Pedro Beicht, e da Graça, produzindo 1,3mil litros de água por segundo. Baixo Cotia, cuja água provém, também, da barragem do rio Cotia, com 900 litros de água por segundo. Ribeirão da Estiva, contribui com 100 mil litros proveniente do rio do mesmo nome.
} 


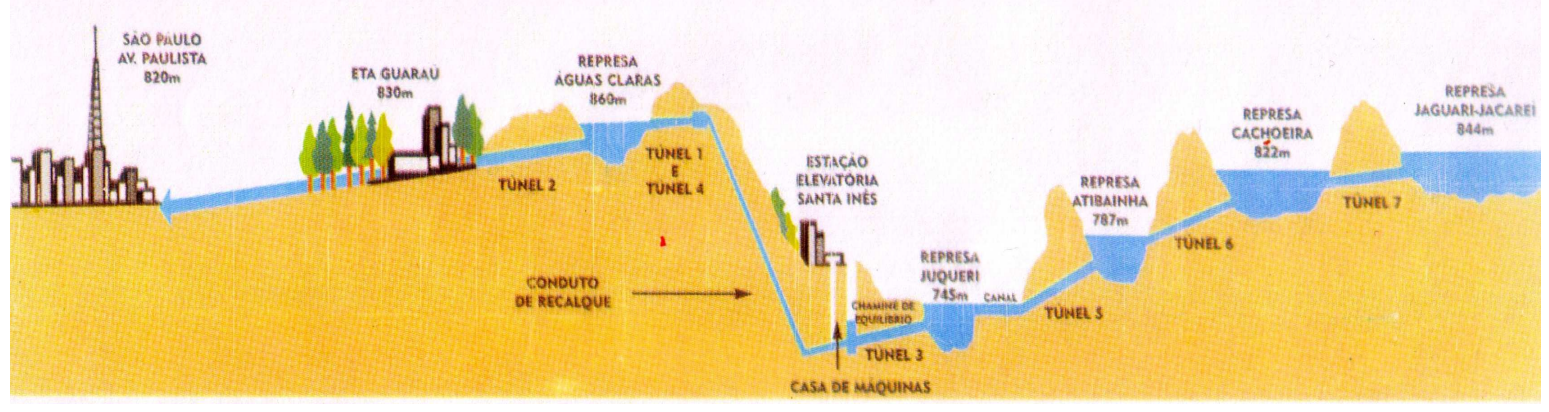

Sistema Cantareira Atual

Alguns cuidados foram postos em prática no início da formação dos três lagos artificiais, como por exemplo:

1. Desapropriação de toda bacia imbrífera, que tinha a finalidade de remover os habitantes e evitar a presença de animais, pastos e plantações.

2. Abertura de valetas de proteção no entorno da bacia hidráulica, para deter os corpos arrastados pelas enxurradas e impedir que as águas fossem facilmente corrompidas em tempo chuvoso;

3. Roçada, destocamento e capina da área imersa.

Grandes debates eram travados no mundo inteiro entre médicos, engenheiros e sanitaristas a respeito das precauções que deveriam ser tomadas para a proteção das bacias, como por exemplo, o que dizia respeito às desapropriações, que possibilitassem estar a área inteiramente livre de habitações e sujeita à vigilância contínua, embora para os governos essas atitudes, em alguns casos, representassem o dispêndio de somas muito elevadas para sua execução.

Outras medidas cautelares diziam respeito às correntes aéreas, temperatura e profundidade do lago, a necessidade da filtração, a proteção de suas margens, com o emprego de diques de alvenaria de pedra e outros tantos.

Apesar de todas as precauções e de acordo com os relatórios da R.A.E. ${ }^{144}$ logo após o enchimento da bacia do Engordador, em 1907, os técnicos detectaram uma perturbação na qualidade do líquido, que muito tênue no inicio, foi se acentuando de tal maneira com o correr dos meses, que alterou a composição química da água, tornando evidentes e inequívocos os indícios de fermentação.

\footnotetext{
${ }^{144}$ Relatórios da Repartição de Águas e Esgotos de São Paulo, de 1907/1908, apresentados ao Secretário da Agricultura pelo seu Diretor, Typographida Brazil - Rothschild \& Co., São Paulo, 1909.
} 
Houve, também alteração de seus caracteres organolépticos, com uma sensível mudança na cor, permanecendo, no entanto, insípida e inodora. O grau de coloração que, a princípio, era produzido pelos sedimentos terrosos em suspensão, tornou-se mais elevado devido à presença de substâncias orgânicas em dissolução e de seres vivos flutuando na massa líquida.

O Diretor da R.A.E. não tinha explicações sobre o porquê da manutenção da cor amarela esverdeada da água armazenada pela barragem do Engordadador, uma vez que o processo da decantação teria contribuído para depositar no fundo as matérias em suspensão arrastadas pela corrente, o que pelo menos, em hipótese, teria contribuído para amenizar a cor e a turbidez, tão sensíveis por ocasião dos exames. Segundo ele, todas as "precauções recomendadas foram postas em pratica: roçada, destocamento, capina, remoção de detritos e abertura de valletas de proteçcção. Mas a terra vegetal - o humus - não foi removida, as raízes não foram extirpadas, os brejos não foram drenados e as margens não foram alcantiladas nem protegidas, de modo que se formou a zona de fraca profundidade e houve o ensejo de se constituírem os remansos nas grotas ou reintrancias do valle". ${ }^{145}$

Pelo exposto, observa-se que as margens do lago do Engordador não foram escarpadas e nem tão pouco houvera a remoção dos sedimentos da área imersa, fato que aliado à existência de terrenos alagadiços de um lado e a decomposição das matérias orgânicas de origem animal e vegetal de outro, estariam entre as causas predominantes do elevado grau de coloração das águas submetidas à análise e condenadas ao consumo.

A evidência dos fatos, tornou imprescindível um estudo mais acurado sobre a qualidade das águas que os paulistanos consumiriam, e que foi realizada por Henri Potel, chefe dos laboratórios de Análise Química da Repartição de Águas e Esgotos, que constatou no lago artificial, a riqueza da flora, principalmente de algas e da fauna, protozoários e metazoários, causas predominantes do grau elevado da coloração da água.

As pesquisas também constataram a presença de resíduos voláteis, amoníaco salino e albuminóide, substâncias orgânicas e corpos em suspensão, indícios claros de fermentação provocada pela estagnação e pelas matérias

\footnotetext{
${ }^{145}$ Relatórios da Repartição de Águas e Esgotos de São Paulo, de 1907/1908, apresentados ao Secretário da Agricultura, pelo seu Diretor, Typographia Brazil - Rothschild \& Co., São Paulo, 1909, p.14.
} 
orgânicas decompostas, bem como vestígios de nitritos, indicadores de grave suspeição, o que constituía fato raro nas águas de São Paulo, segundo a literatura da época.

Barragem do Guarahú, 1909 - Córrego de Guarahú

\begin{tabular}{|c|c|c|c|c|c|c|c|c|c|c|c|c|}
\hline Meses & 兽 & ¿̀ & 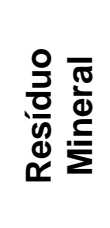 & 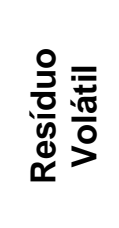 & $\frac{\circ}{0}$ & 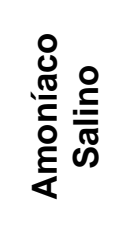 & 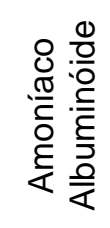 & 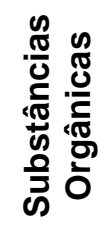 & 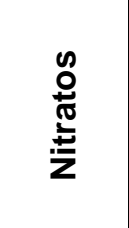 & 总 & 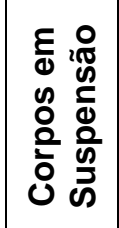 & 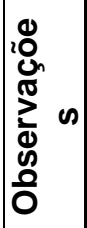 \\
\hline $\begin{array}{l}\text { Julho } \\
\text { Agosto }\end{array}$ & & $\begin{array}{l}1.6 \\
1.0 \\
0.8 \\
0.6\end{array}$ & $\begin{array}{l}2.380 \\
2.220 \\
2.400 \\
2.200\end{array}$ & $\begin{array}{l}0.460 \\
0.580 \\
0.520 \\
0.680\end{array}$ & $\begin{array}{l}0.126 \\
0.113 \\
0.142 \\
0.126\end{array}$ & $\begin{array}{l}0.001 \\
0.001 \\
0.003 \\
0.003\end{array}$ & $\begin{array}{l}0.001 \\
0.004 \\
0.006 \\
0.006\end{array}$ & $\begin{array}{l}0.474 \\
0.442 \\
0.696 \\
0.442\end{array}$ & $\begin{array}{l}0.086 \\
0.056 \\
0.114 \\
0.021\end{array}$ & $\begin{array}{l}\text { Não tem } \\
\text { Não tem } \\
\text { Não tem } \\
\text { Não tem }\end{array}$ & $\begin{array}{l}0.10 \\
0.03 \\
0.14 \\
0.08\end{array}$ & \\
\hline $\begin{array}{l}\text { Máximo } \\
\text { Médio } \\
\text { Mínimo }\end{array}$ & - & $\begin{array}{l}1.6 \\
1.0 \\
0.6\end{array}$ & $\begin{array}{l}2.400 \\
2.300 \\
2.200\end{array}$ & $\begin{array}{l}0.680 \\
0.560 \\
0.460\end{array}$ & $\begin{array}{l}0.142 \\
0.127 \\
0.113\end{array}$ & $\begin{array}{l}0.004 \\
0.003 \\
0.003\end{array}$ & $\begin{array}{l}0.006 \\
0.005 \\
0.004\end{array}$ & $\begin{array}{l}0.695 \\
0.613 \\
0.442\end{array}$ & $\begin{array}{l}0.114 \\
0.069 \\
0.021\end{array}$ & & $\begin{array}{l}0.14 \\
0.09 \\
0.03\end{array}$ & \\
\hline
\end{tabular}

Represa do fundo da Barragem

\begin{tabular}{|c|c|c|c|c|c|c|c|c|c|c|c|}
\hline Julho & & $\begin{array}{l}2.4 \\
2.4 \\
1.0 \\
5.0\end{array}$ & $\begin{array}{l}2.980 \\
2.760 \\
2.760 \\
3.280\end{array}$ & $\begin{array}{l}0.720 \\
0.720 \\
0.900 \\
1.120\end{array}$ & \begin{tabular}{|l}
0.085 \\
0.057 \\
0.057 \\
0.099
\end{tabular} & $\begin{array}{l}0.021 \\
0.003 \\
0.004 \\
0.004\end{array}$ & $\begin{array}{l}0.022 \\
0.017 \\
0.027 \\
0.024\end{array}$ & $\begin{array}{l}0.980 \\
0.727 \\
0.695 \\
0.822\end{array}$ & $\begin{array}{l}0.068 \\
0.036 \\
0.090 \\
0.061\end{array}$ & $\begin{array}{l}\text { Não tem } \\
\text { Vestígios }\end{array}$ & $\begin{array}{l}0.34 \\
0.35 \\
0.39 \\
0.58\end{array}$ \\
\hline $\begin{array}{l}\text { Máximo } \\
\text { Médio } \\
\text { Mínimo }\end{array}$ & - & $\begin{array}{l}5.0 \\
2.7 \\
1.0\end{array}$ & $\begin{array}{l}3.280 \\
2.942 \\
2.760\end{array}$ & $\begin{array}{l}1.120 \\
0.865 \\
0.720\end{array}$ & $\begin{array}{l}0.099 \\
0.074 \\
0.057\end{array}$ & $\begin{array}{l}0.021 \\
0.008 \\
0.003\end{array}$ & $\begin{array}{l}0.027 \\
0.022 \\
0.017\end{array}$ & $\begin{array}{l}0.980 \\
0.806 \\
0.695\end{array}$ & $\begin{array}{l}0.090 \\
0.063 \\
0.036\end{array}$ & & $\begin{array}{l}0.53 \\
0.40 \\
0.34\end{array}$ \\
\hline
\end{tabular}


Barragem do Guarahú, 1909 - Barragem Esvaziada

\begin{tabular}{|c|c|c|c|c|c|c|c|c|c|c|c|}
\hline Meses & 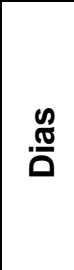 & ১े & 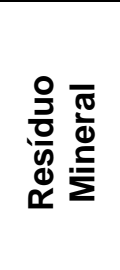 & 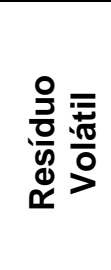 & $\frac{\circ}{0}$ & 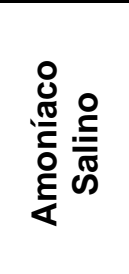 & 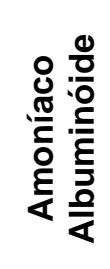 & 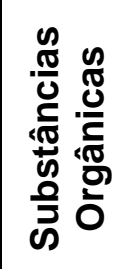 & 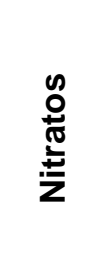 & 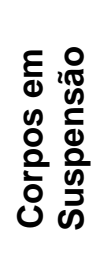 & 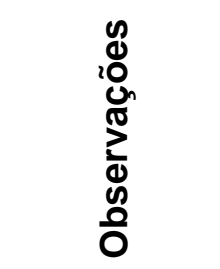 \\
\hline Outubro & 24 & 7.3 & 2.340 & 0.100 & 1.560 & 0.160 & 0.160 & 8.530 & 0.82 & 0.32 & \\
\hline Novembro & $\begin{array}{l}12 \\
21 \\
28\end{array}$ & $\begin{array}{l}5.32 \\
4.22 \\
4.02\end{array}$ & $\begin{array}{l}3.800 \\
3.400 \\
6.000\end{array}$ & $\begin{array}{l}1.000 \\
7.800 \\
9.809\end{array}$ & $\begin{array}{l}1.490 \\
1.420 \\
0.110\end{array}$ & $\begin{array}{l}0.409 \\
0.290 \\
0.410\end{array}$ & $\begin{array}{l}0.231 \\
0.150 \\
0.260\end{array}$ & $\begin{array}{l}3.590 \\
9.480 \\
9.480\end{array}$ & $\begin{array}{l}0.82 \\
0.96 \\
1.76\end{array}$ & $\begin{array}{l}0.81 \\
0.61 \\
0.70\end{array}$ & $\begin{array}{l}\text { (Esvaziada) } \\
\text { (Esvaziada) }\end{array}$ \\
\hline
\end{tabular}

Barragem do Cabuçu, 1909

\begin{tabular}{|c|c|c|c|c|c|c|c|c|c|c|c|}
\hline Meses & 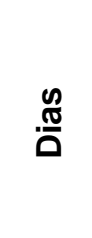 & ¿̀ं & 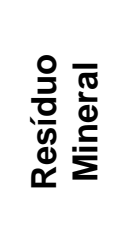 & 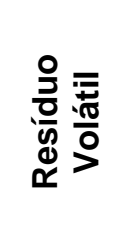 & $\frac{\circ}{0}$ & 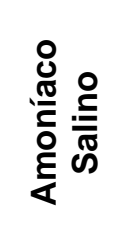 & 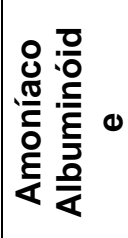 & 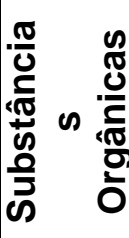 & 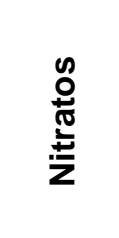 & 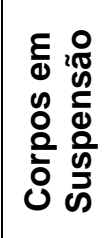 & 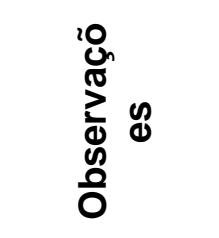 \\
\hline $\begin{array}{l}\text { Abril } \\
\text { Maio } \\
\text { Junho } \\
\text { Julho } \\
\text { Agosto } \\
\text { Setembro } \\
\text { Outubro } \\
\text { Novembro } \\
\text { Dezembro }\end{array}$ & $\begin{array}{c}17 \\
14 \\
14 \\
21 \\
25 \\
26 \\
20 \\
25 / 26 \\
22 \\
19 \\
17 \\
14 \\
26\end{array}$ & $\begin{array}{l}6.1 \\
5.3 \\
5.7 \\
5.7 \\
4.0 \\
5.0 \\
6.6 \\
3.2 \\
6.4 \\
8.0 \\
6.6 \\
5.0 \\
6.6\end{array}$ & $\begin{array}{l}2.920 \\
2.560 \\
2.800 \\
2.680 \\
2.440 \\
2.500 \\
2.640 \\
2.740 \\
3.120 \\
2.900 \\
3.080 \\
2.560 \\
3.240\end{array}$ & $\begin{array}{l}2.140 \\
1.860 \\
1.280 \\
1.200 \\
0.980 \\
0.940 \\
1.300 \\
1.020 \\
1.440 \\
1.960 \\
0.800 \\
1.360 \\
1.640\end{array}$ & $\begin{array}{l}0.784 \\
0.142 \\
0.184 \\
0.142 \\
0.142 \\
0.142 \\
0.142 \\
0.156 \\
0.156 \\
0.184 \\
0.170 \\
0.163 \\
0.142\end{array}$ & $\begin{array}{l}0.006 \\
0.006 \\
0.004 \\
0.004 \\
0.028 \\
0.018 \\
0.039 \\
0.010 \\
0.002 \\
0.002 \\
0.050 \\
0.006 \\
0.006\end{array}$ & $\begin{array}{l}0.035 \\
0.042 \\
0.031 \\
0.033 \\
0.061 \\
0.018 \\
0.069 \\
0.043 \\
0.032 \\
0.033 \\
0.012 \\
0.021 \\
0.039\end{array}$ & $\begin{array}{l}2.086 \\
2.054 \\
1.296 \\
1.169 \\
1.770 \\
0.727 \\
2.149 \\
0.916 \\
1.074 \\
1.801 \\
0.916 \\
1.232 \\
2.212\end{array}$ & $\begin{array}{l}0.121 \\
0.061 \\
0.081 \\
0.065 \\
0.071 \\
0.057 \\
0.053 \\
0.076 \\
0.064 \\
0.071 \\
0.074 \\
0.117 \\
0.070\end{array}$ & $\begin{array}{l}0.35 \\
0.64 \\
1.14 \\
1.14 \\
1.94 \\
0.62 \\
1.17 \\
0.31 \\
0.76 \\
0.87 \\
1.25 \\
0.74 \\
0.82\end{array}$ & $\begin{array}{l}\text { (Esvaziada) } \\
\text { (Esvaziada) }\end{array}$ \\
\hline $\begin{array}{l}\text { Máximo } \\
\text { Médio } \\
\text { Mínimo }\end{array}$ & & $\begin{array}{l}6.6 \\
5.7 \\
3.0\end{array}$ & $\begin{array}{l}3.240 \\
2.783 \\
2.440\end{array}$ & $\begin{array}{l}2.140 \\
1.378 \\
0.800\end{array}$ & $\begin{array}{l}0.184 \\
0.159 \\
0.142\end{array}$ & $\begin{array}{l}0.050 \\
0.014 \\
0.002\end{array}$ & \begin{tabular}{|l|}
0.069 \\
0.036 \\
0.012
\end{tabular} & $\begin{array}{l}2.212 \\
1.492 \\
0.916\end{array}$ & $\begin{array}{l}0.121 \\
0.075 \\
0.053\end{array}$ & $\begin{array}{l}1.94 \\
0.95 \\
0.31\end{array}$ & \\
\hline
\end{tabular}

Nota: Não tem nitritos, é inodora e insípida

Grau hydrotimétrico inferior a 0.05 
Barragem do Engordador, 1909

\begin{tabular}{|c|c|c|c|c|c|c|c|c|c|c|c|}
\hline Meses & 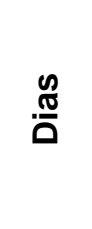 & ¿̀ & 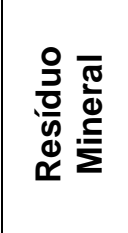 & 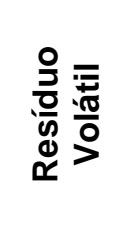 & $\frac{\circ}{0}$ & 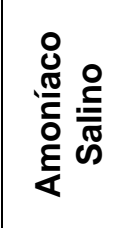 & 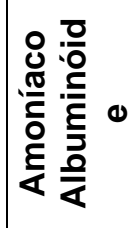 & 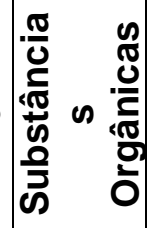 & 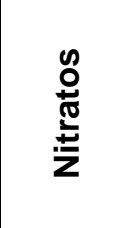 & 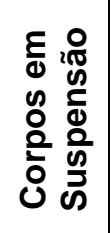 & Observações \\
\hline $\begin{array}{c}\text { Janeiro } \\
\text { Fevereiro } \\
\text { Março } \\
\text { Maio } \\
\text { Junho } \\
\text { Agosto } \\
\text { Setembro } \\
\text { Outubro } \\
\text { Novembro } \\
\text { Dezembro }\end{array}$ & $\begin{array}{c}24 \\
21 \\
28 \\
2 \\
30 \\
27 \\
1 \\
29 \\
26 \\
24 \\
21\end{array}$ & $\begin{array}{l}4.6 \\
4.0 \\
4.7 \\
5.0 \\
6.6 \\
6.1 \\
4.7 \\
6.3 \\
5.3 \\
6.6 \\
3.2\end{array}$ & $\begin{array}{l}2.120 \\
2.200 \\
2.180 \\
2.140 \\
2.520 \\
2.380 \\
2.500 \\
2.369 \\
2.340 \\
2.180\end{array}$ & $\begin{array}{l}1.180 \\
1.760 \\
1.260 \\
1.580 \\
1.280 \\
1.600 \\
1.300 \\
1.200 \\
1.010 \\
0.940\end{array}$ & $\begin{array}{l}0.142 \\
0.181 \\
0.170 \\
0.156 \\
0.184 \\
0.170 \\
0.213 \\
0.184 \\
0.213 \\
0.170 \\
0.156\end{array}$ & $\begin{array}{l}0.005 \\
0.004 \\
0.004 \\
0.003 \\
0.003 \\
0.003 \\
0.003 \\
0.002 \\
0.005 \\
0.046 \\
0.004\end{array}$ & $\begin{array}{l}0.031 \\
0.029 \\
0.042 \\
0.043 \\
0.039 \\
0.032 \\
0.041 \\
0.032 \\
0.041 \\
0.039 \\
0.014\end{array}$ & $\begin{array}{l}1.612 \\
1.327 \\
2.117 \\
1.422 \\
1.359 \\
1.296 \\
1.422 \\
1.201 \\
1.264 \\
2.022 \\
1.138\end{array}$ & $\begin{array}{l}0.086 \\
0.080 \\
0.050 \\
0.083 \\
0.040 \\
0.045 \\
0.047 \\
0.056 \\
0.059 \\
0.111 \\
0.109\end{array}$ & $\begin{array}{l}0.36 \\
0.45 \\
0.55 \\
0.21 \\
0.47 \\
0.49 \\
0.64 \\
0.37 \\
3.48 \\
0.57\end{array}$ & $\begin{array}{c}\text { Choveu nos dias } \\
18 \text { a } 26 \\
\text { Choveu nos dias } \\
15,16,18,19 \\
\text { Choveu nos dias } \\
22,23 \text { e } 26 \\
\\
\text { Choveu no dia } 28 \\
\text { Choveu nos dias } \\
22,23,25,26 \\
\text { Sobras da }\end{array}$ \\
\hline $\begin{array}{l}\text { Máximo } \\
\text { Médio } \\
\text { Mínimo }\end{array}$ & - & $\begin{array}{l}6.6 \\
5.2 \\
3.2\end{array}$ & $\begin{array}{l}2.520 \\
2.292 \\
2.120\end{array}$ & $\begin{array}{l}1.760 \\
1.314 \\
0.940\end{array}$ & $\begin{array}{l}0.213 \\
0.177 \\
0.142\end{array}$ & \begin{tabular}{|l|}
0.046 \\
0.007 \\
0.002
\end{tabular} & $\begin{array}{l}0.043 \\
0.035 \\
0.014\end{array}$ & $\begin{array}{l}2.117 \\
1.471 \\
1.138\end{array}$ & $\begin{array}{l}0.111 \\
0.070 \\
0.040\end{array}$ & $\begin{array}{l}3.48 \\
0.76 \\
0.21\end{array}$ & $\begin{array}{c}\text { Choveu no dia } 24 \\
\text { Choveu nos dias } \\
18,19,20,21 \\
\text { Esavaziada }\end{array}$ \\
\hline
\end{tabular}

Nota: Não tem nitritos, é inodora e insípida

Grau hydrotimétrico inferior a 0.05 .

Em conseqüência elevou-se consideravelmente o grau de coloração da água, "esse phenomeno, imprevisto em tal intensidade pela maioria dos autores sanitarios, talvez seja explicável pelas condições climatericas, pela fauna e flora da água, quiçá pela natureza do terreno, exuberante de seiva". ${ }^{146}$

O diretor da Comissão de Obras Novas, Luiz Betim Paes Leme, quando, em 1907, fechou as comportas da barragem, a título de experiência e na tentativa de combater esses microorganismos, decidiu lançar às águas o sulfato de cobre, (S O4 $\mathrm{CU})$, que começava a ser empregado, com sucesso, em alguns países do mundo; porém, com relação ao Engordador, houve apenas a morte de alguns peixes e nada mais.

Nesses produtos químicos, era desconhecida por muitos a dosagem que pudesse ser considerada inócua para os seres humanos a longo prazo, e seu emprego, motivo de controvérsias entre os especialistas em saneamento e abastecimento público de água, na Europa e Estados Unidos.

\footnotetext{
${ }^{146}$ Relatório da Secretaria dos Negócios da Agricultura, Commercio e Obras Publicas do Estado de São Paulo de 1908, apresentado ao Presidente do Estado pelo Secretário da Agricultura, Typographia Casa Garraux, São Paulo, 1909, p.278.
} 
O lago continuava até então isolado do abastecimento público e o emprego do algicida, segundo do Diretor da R.A.E., era inadequado por ser corretivo apenas do cheiro e do gosto produzidos nas águas por esse vegetal, e as do Engordador eram consideradas insípidas e inodoras, o que de antemão condenaria seu emprego, aconselhando-se mais um tempo para que a água em repouso pudesse produzir sua auto-depuração.

Segundo o Relatório da R.A.E., até outubro de 1908, a imobilidade das águas não havia contribuído para a melhoria de sua potabilidade; novamente as análises revelaram que havia perturbação no líquido armazenado obrigando os técnicos, a usarem mais uma vez o algicida, o que foi feito a 11 de Outubro do mesmo ano, através de um bote, que percorreu o lago em vários sentidos, emergindo sacos e cestos contendo o sal de cobre.

Durante as três primeiras semanas foi esparsa a substância tóxica a cada sete dias: 11, 18 e 25 de Outubro e nas seguintes proporções: um (1) litro para trinta (30) milhões de litros de água, um (1) para vinte (20) milhões e um (1) para dezessete (17) milhões.

Nas quatro semanas seguintes, e de acordo com o mesmo relatório, derramou-se uma solução concentrada de sulfato de cobre, adotando-se um dispositivo de funcionamento intermitente nos mananciais que alimentavam o lago; a aplicação também foi feita uma vez, durante quatro semanas, no mês de Novembro do mesmo ano, porém, em menores proporções: 1:20 milhões, 1:14 milhões, novamente a mesma proporção e 1:10 milhões.

Para os exames bacteriológicos e análises químicas durante a fase da experiência, foram colhidas águas em vários pontos da superfície e em camadas diversas do lago, em suas margens, nas embocaduras dos córregos e junto à barragem.

O resultado dos exames acusou, gosto e cheiro desagradáveis, de choco, sinal evidente de fermentação pútrida, e a não diminuição da quantidade de protozoários, algas e outros micro-organismos, notando-se, ao contrário, aumento de substâncias orgânicas: amoníaco albuminóide e nitritos, sendo constante o aumento do grau de coloração. Essas alterações produzidas nos caracteres físicos, e na composição química das águas, eram devidas à morte de peixes e ao acréscimo dos organismos destruídos. 
Segundo os especialistas da época, essa perturbação permaneceria por apenas dois dias, quando então deveria haver uma melhora da qualidade do liquido armazenado, fato que não aconteceu com a experiência realizada no Engordador. ${ }^{147}$ Portanto, ao contrário do esperado, a utilização desses procedimentos ao invés de beneficiar as águas, tornou-as ainda mais impróprias ao consumo, e no dia 8 de Dezembro, sem qualquer alternativa, o lago começou a ser esgotado para sua limpeza e depuração, não sem antes terem lançado o sulfato de cobre na proporção de um (1) litro para cinco (5) milhões de litros de água.

O esvaziamento completo se efetuou no dia 28 do mesmo mês, tendo-se então começado o reparo das comportas e a limpeza do vale que estava coberto com uma camada de lodo de $0,10 \mathrm{~m}$ a $0,20 \mathrm{~m}$ de espessura nas vertentes e no antigo vale do córrego.

De acordo com os relatórios, ao saírem as últimas águas, sentiu-se um cheiro pútrido que foi se acentuando a ponto de ser percebido a 100 metros de distância.

Somente a 14 de janeiro de 1909, foram novamente fechadas as comportas, para o enchimento do lago a razão de 22.700.000 litros diários, por se tratar da estação chuvosa, atingindo sua plena capacidade a 4 de fevereiro do mesmo ano. Entretanto, para que não houvesse crise mais séria no abastecimento da zona alta da cidade, foi necessário o concurso da bomba do Engordador para elevar as águas do lago artificial que, isolado do abastecimento, foi utilizado pela R.A.E. de setembro de 1910 em diante, quando as analises de suas águas indicaram uma melhoria em sua potabilidade. ${ }^{148}$

Se no caso do Engordador apenas a limpeza, filtração e arejo das águas teriam sido suficientes para seu tratamento, segundo o Diretor da R.A.E., o mesmo não se podia dizer do lago do Cabuçu; a diferença residia nas várias espécies de algas que habitavam no lago e que, ao contrário do Engordador, exalavam mau cheiro e contaminavam o líquido armazenado. Para este caso, apenas a aeração (processo para saturação da água de oxigênio) não produziu resultados e o posterior funcionamento dos filtros mostrou-se insuficiente. Foi, portanto, necessária a adoção do sulfato de cobre proposto pelos departamentos de Agricultura dos Estados Unidos e da França e por muitos médicos e engenheiros sanitaristas especializados

\footnotetext{
${ }^{147}$ Relatório da Repartição de Aguas e Esgotos de São Paulo, de 1907/1908, apresentado ao Secretário da Agricultura pelo Diretor, São Paulo, Typographia Brazil-Rothschild \& Co., 1909, p. 17.

${ }_{148}$ Mensagem enviada ao Congresso Legislativo do Estado de São Paulo, em 14 de julho de 1911, pelo Presidente do Estado, São Paulo, 1911, p.37.
} 
em abastecimento de água e saneamento como meio de eliminar a maioria das bactérias patogênicas, embora se constatasse que existiam espécies de algas resistentes ao tratamento.

Conhecido desde 1890 na Europa, e cujo aperfeiçoamento do método de emprego se deve aos cientistas Moore e Kellerman, em 1905, marcou o inicio de um moderno tratamento no controle do mal das algas.

Francamente favoráveis ao seu emprego, estavam autoridades da época como: Imbeaux ${ }^{149}$ e Debauve ${ }^{150}$, para os quais a dose de um (1) litro de algicida para um (1) milhão de litros de água seria letal para a maioria das espécies de algas, protozoários e mesmo para certas bactérias patogênicas, sem surgir nenhum inconveniente para o homem.

Da mesma opinião era Pagliani ${ }^{151}$, que citava experiência vitoriosa feita em Kentucky, no lago de Clifton e em Baltimore no Mombello, com a solução um (1) litro de sulfato de cobre para seis (6) milhões e quinhentos (500) mil litros de água, que destruiu as algas fétidas e manteve a água inodora.

Kemna, ${ }^{152}$ fervoroso adepto do sistema norte americano,indicava seu uso com insistência em diversos ensaios onde relata suas próprias experiências vitoriosas em Antuérpia, por exemplo no combate à alga Eudovina e outras formas. Dedicando-se à pesquisa biológica, o mesmo autor combate a objeção de outros cientistas acerca da ação tóxica dos compostos de cobre e sobre a necessidade de se precipitar o metal por via química, eliminando-o em seguida pelo meio mecânico da filtração. Para o autor, o organismo humano suportaria perfeitamente a dose de um grama de sal de cobre por dia. ${ }^{153}$

Nas primeiras décadas do século $X X$, porém, seus efeitos e conseqüências a longo prazo ainda não haviam sido devidamente observados e estudados, Hazen ${ }^{154}$

\footnotetext{
${ }^{149}$ IMBEAUX, Édouard. Médico e engenheiro francês, diretor dos Serviços Municipais de Nancy durante vinte e dois anos e fundador da Associação Geral dos Engenheiros e Arquitetos e Higienistas municipais da França.

${ }^{150}$ DEBAUVE, Alphonse Aléxis. Engenheiro hidráulico francês, especialista em saneamento.

${ }^{151}$ PAGLIANI, Luigi. Médico de higiene e saúde pública e professor de higiene na Universidade de Turim, Itália, de 1881 a 1924.

${ }^{152}$ KEMNA, A. Engenheiro inglês, com inúmeros trabalhos na British Association of Water-Werks Enginners, onde expõe o sucesso do uso do algicida em várias experiências.

${ }_{153}$ Relatórios da Repartição de Águas e Esgotos de São Paulo, 1907/1908, apresentado ao Secretario da Agricultura pelo seu Diretor, São Paulo, Typographia Brazil-Rothschild \& Co., São Paulo, 1909.

${ }^{154}$ HAZEN, Allen. Químico e engenheiro sanitarista norte americano, especialista em abastecimento e qualidade da água.
} 
e Whipple ${ }^{155}$, por exemplo, eram muito mais moderados e mantinham-se em expectativa prudente.

Para eles: "it is therefore possible, with due care, to kill the algae without endangering the heath of the people who use the water."156 Alertava também para 0 fato de que o cobre exterminava algumas espécies de organismos, não todas, e à medida que o uso se prolongava, abria-se perigoso caminho para o nascimento de formas mais fortes e difíceis de serem eliminadas.

Embora os autores considerassem que o algicida havia sido empregado em muito reservatórios e em larga escala, com relativo sucesso, pouco se sabia sobre sua propriedade tóxica e seus efeitos fisiológicos na população, o que exigia que urgentemente se obtivessem dados mais precisos sobre a matéria e alertava:

The promiscous use of copper by those who have no knowledge of chemistry or of the physical laws which govern the circulation of large bodies of water, should be emphatically condemned. ${ }^{157}$ (WHIPPLE, 1907)

Para o Diretor da R.A.E. essas considerações eram mais que suficientes para enfatizar sua posição contra a inocuidade do emprego de produtos químicos para o tratamento da água, especialmente do Sulfato de cobre, porque, embora não lhe fosse atribuída ação tóxica de efeitos apreciáveis, poderiam manifestar-se no organismo humano conseqüências fisiológicas que ainda não tivessem sido observadas nem estudadas.

Dizia: "não me é licito assumir tão séria responsabilidade, quando poderia ser condemnado pela classe medica de São Paulo e acoimado pelo publico que attribuiria todas as suas indisposições aos efeitos perniciosos do tratamento chimico, adoptado pela Repartição de Aguas". 158

\footnotetext{
${ }^{155}$ WHIPPLE, George Chandler. Engenheiro norte americano, especialista em tratamento da água, prevenção e controle de sua qualidade.

${ }^{156}$ HAZEN, Allen, in Relatórios da Repartição de Água e Esgotos de São Paulo, 1907/1908, apresentado ao Secretario da Agricultura pelo seu Diretor, São Paulo, Typographia Brazil-Rothschild \& Co., São Paulo, 1909.

${ }^{157}$ WHIPPLE, George Chandler. The Microscopy of drinking water. Editora John Wiley, \&. Sons, 1907, Nova York, p.158.

${ }^{158}$ Relatórios da Repartição de Águas e Esgotos de São Paulo de 1907/1908, apresentado ao Secretário da Agricultura, pelo seu Diretor.Typoghraphia Brazil-Rothschild \& Co.São Paulo, 1909, p.21.
} 
Segundo os relatórios da R.A.E, a barragem do Guaraú parecia ter sido a única onde não haviam se manifestado com a mesma intensidade os inconvenientes dos outros dois lagos artificiais: Engordador e Cabuçu. O lago foi incluído no abastecimento em razão do resultado positivo das análises químicas e bacteriológicas. Sua inauguração se deu em Setembro de 1908, e foi utilizado até o final desse exercício, quando o fornecimento foi interrompido, após um alerta do Instituto Bacteriológico, que havia detectado a impotabilidade de suas águas. A ausência de sua contribuição representaria um déficit considerável na tentativa de regularizar o abastecimento de água na cidade de São Paulo.

Em mensagem enviada ao Legislativo Paulista, o Presidente do Estado de São Paulo, em 1909, alertava: "não se póde prescindir, sem prejuizo para o abastecimento, da contribuição do lago do Guarahú, estando, por isso, a Repartição de Aguas e Exgottos empenhada em resolver urgentemente a questão do aproveitamento destas aguas sem prejuizo do estudo que tem feito, dos meios que possam tambem tornar aproveitaveis as aguas dos lagos do Engordador e Cabuçu". 159

A R.A.E., na tentativa de solucionar o problema o mais rápido possível, estudava a influência exercida pela aeração nos filtros lentos de areia submersos e não submersos, porém, o grande empecilho residia no aqueduto que atravessava o corpo da barragem colocado em nível muito baixo, só podendo descarregar a água no clarificador existente.

A única saída seria a construção de novos aparelhos a jusante do pré-filtro, porém, segundo o Diretor da repartição, três considerações o fizeram abandonar essa solução:

1. "Não se dispôr de areia sufficiente, por haver um despenhadeiro logo abaixo do clarificador;

2. Por se diminuir a vazão da linha de 0,m60 com a diminuição da carga actual;

3. Por comprometter as aguas da ala direita a não ser que se preparassem os meios de tratamento independentes do prefiltro e linha adductora por onde passam as outras aguas que ora são aproveitadas". ${ }^{160}$

\footnotetext{
${ }^{159}$ Mensagem enviada ao Congresso Legislativo do Estado de São Paulo, a 14 de Julho de 1909, pelo Presidente do Estado. São Paulo, 1909, p.38.

${ }^{160}$ Relatório da Repartição de Águas e Esgotos de São Paulo, de 1909, apresentado pelo seu Diretor, ao Secretário de Agricultura, Comércio e Obras Públicas.São Paulo, Ed. Casa Garraux 1910, p.13.
} 
Segundo os relatórios da Secretaria da Agricultura e da R.A.E., para remediar a situação e minimizar as conseqüências graves que assolavam a cidade com as estiagens prolongadas, o córrego do Guaraú foi captado diretamente e suas águas seguiam por um pequeno aqueduto de $0.30 \mathrm{~m}$ de diâmetro interno, e 840,80m de comprimento, paralelo à valeta de proteção da encosta da barragem, desaguando no clarificador através de um conduto forçado de 0,25m de diâmetro e 293,5m sem se misturar com as águas do lago, que a partir daí, ficou isolado do abastecimento.

Os estudos minuciosos feitos pelo laboratório da R.A.E. indicavam que a água do córrego era sempre potável, não acontecendo o mesmo com a da represa. Diversas vezes eram colhidas amostras em pontos diferentes do lago e os técnicos chegavam à conclusão que o pior líquido ficava no centro da bacia.

Os resultados das análises químicas classificavam de impotável a água do lago, e os fatores preponderantes apontados para sua condenação consistiam na presença excessiva de substâncias albuminóides e amoniacais: nitritos e nitratos. Os exames bacteriológicos também apresentavam conclusões negativas, levando as autoridades a tomarem medida drástica de esgotamento total do lago entre 6 a 21 de outubro de 1909 permanecendo vazio até 25 de novembro daquele ano. Durante esse intervalo de tempo, foram feitos reparos na placa de proteção do talude de montante, nos lugares em que foram notadas fendas bem pronunciadas.

A barragem do Cabuçu até então (1909), não havia formado o lago em sua plenitude, em razão da necessidade que os técnicos tiveram de manter a descarga aberta "com o fim de não afogar o canal que passava em forma de gaveta aderente ao maciço da barragem e que conduz a água do ribeirão, tomada na represa á cidade". ${ }^{161}$ Além dessa circunstância, outro inconveniente obrigou-os a manter baixo o nível do lago: vários acidentes provocados na encosta por onde passava o canal de seção trapezoidal que conduzia a água para o abastecimento. Os taludes desmoronaram em diversos pontos, provocando vazamento no canal e quase comprometeram a estabilidade da obra de concreto. Suas águas mantiveram-se impotáveis durante 1909 e o lago ficou completamente vazio de outubro a novembro daquele ano.

Dos três lagos artificiais, o complexo do Guaraú não mais existe; em 1974, foi completamente destruído, para que o solo fosse rebaixado em $20 \mathrm{~m}$ de profundidade, para dar lugar a Estação de Tratamento de Águas, conhecida como 
ETA GUARAÚ, projetada para operar com uma capacidade final de $33 \mathrm{~m}^{3} / \mathrm{s}$, o que a torna uma das maiores estações de tratamento de água do mundo. A água que a alimenta provém das barragens dos rios Juqueri, Atibainha, Cachoeira, Jacareí e Jaguari. É bombeada da Elevatória de Santa Inês para o reservatório de Águas Claras. A água bruta deste reservatório flui por gravidade através da estação e pelo reservatório regulador, sendo conduzida ao sistema de distribuição como água tratada.

Na primeira década do século $\mathrm{XX}$, as águas dos nossos lagos artificiais foram temporariamente condenadas para o consumo em razão dos resultados negativos das análises e dos exames microscópicos a que foram submetidas. Plínio Queiroz, vinte anos depois da inauguração das barragens afirmava:

\begin{abstract}
Infelizmente as nossas aguas estão sujeitas ao mal das algas, como acontece em muitos casos da América do Norte. Seu repouso em açudes em vez de Ihes melhorar as qualidades pela decantação dá azo á polluição das algas, pouca influencia tendo a limpeza preliminar da bacia ou seu amadurecimento pela decomposição completa da materia organica que nella se encontrava antes do enchimento. De quando em vez as aguas se turvam adquirem mau cheiro, e mau gosto: apodrecem literalmente. Disto temos um exemplo bem frisante que é o Cabuçu. ${ }^{162}$ (QUEIROZ, 1928)
\end{abstract}

Qual então deveria ser o tratamento adequado a fim de aproveitar em curto prazo as águas que estavam provisoriamente afastadas do abastecimento?

As opiniões eram divergentes, e o debate entre especialistas considerados autoridades, no final do século XIX e começo do XX, continuava, persistindo a falta de consenso quanto ao método a ser aplicado e sua eficácia na melhoria da qualidade da água dos lagos artificiais que a população mundial consumia.

Além dos cuidados comuns que deveriam ser postos em prática no início da construção das represas formadoras das bacias e que eram consideradas práticas rotineiras $^{163}$, alguns engenheiros sanitaristas eram muito exigentes, outros, porém, mais tolerantes.

\footnotetext{
${ }^{162}$ QUEIROZ, Plínio in Revista Viação. Tipografia Agência Will, Rio de Janeiro, 1928, p.117.

${ }^{163}$ Expostas no capítulo da formação dos lagos artificiais.
} 
No caso de SPATARO, $1909,{ }^{164}$ sua recomendação era a de que a bacia deveria ser circundada de montes, exposta à ação das correntes aéreas, sua profundidade teria que ser considerável, a temperatura média do local baixa, a camada de húmus retirada e, além de todas essas exigências, deveriam ser usados filtros de purificação.

FOLWEL, 1900, ${ }^{165}$ mais sintético, enfatizava a necessidade da remoção da terra vegetal e das saliências do terreno, para que se pudesse obter a maior profundidade possível, ainda que esse procedimento se tornasse bastante dispendioso.

Para outros peritos, havia necessidade de aprofundar as margens, protegendo-as com diques cujos taludes fossem revestidos de rip rap ${ }^{166}$, garantindo a mínima profundidade de 1,30 m a 1,50m.

Ainda FANNING, 1906, ${ }^{167}$ insistia na providência dos diques marginais de alvenaria de pedra apoiado por RUSSEL e TURNEAURE, $1903,{ }^{168}$ que citavam grandes extensões em que o circuito inteiro fora assim protegido com total sucesso.

HAZEN e WHIPPLE, 1909, julgavam que ,muitas vezes, era impossível remover os habitantes da bacia imbrífera, não sendo necessário tal procedimento nos casos de imensas bacias e lagos com grande capacidade de armazenamento e alta densidade populacional em seu entorno. ${ }^{169}$

O diretor da R.A.E, em 1909, levando em consideração todos os estudos feitos pelas autoridades mundiais, determinou o renovamento periódico das águas dos três lagos, (Engordador, Cabuçu e Guaraú), no combate à estagnação, retirando todo o lodo sedimentado ao fazer a necessária limpeza, impedindo que a vegetação brotasse e aguardando a ação do tempo, porque segundo os autores de vários países do mundo, as perturbações surgem apenas nos primeiros anos da

\footnotetext{
${ }^{164}$ SPATARO, Donato. Ingegneria Sanitária: provvista dell'acque e risanamento dell'abitato. Edição Vallardi, Milão, 1909.

${ }^{165}$ FOLWEL, Amory Prescott. Water supply engeineerin: the designing, construction, and maintenance of water-supply systems. Editora John Wiley and Sons, New York, 1900.

${ }^{166}$ Rip rap -"enrocamento": é um muro de pedras, simplesmente arrumadas umas sobre as outras sem uso de argamassa de cimento para proteção de taludes de aterros, existem também os rip-rap vegetativos.

${ }^{167}$ FANNING, John Thomas. A practical treatise on hydraulic and water-supply engineering.relating to the hydrology, hydrodynamics and practical construction of water-works in North-America. Ed. Van Nostrand, Nova York, 1906, p.148.

${ }^{168}$ RUSSEL, Harry Luman, e TURNEAURE, Frederick Eugene. Public water-supplies: Requirements, resources, and the construction of works. Ed. John Wiley \& Sons, New York, 1903.

${ }^{169}$ HAZEN, Allen, in Relatórios da Repartição de Agua e Esgotos de São Paulo, 1907/1908, apresentado ao Secretario da Agricultura pelo seu Diretor, São Paulo, Typographia Brazil-Rothschild \& Co., São Paulo, 1909.p.22.
} 
formação dos lagos, havendo uma diminuição lenta, mas gradativa de sua putrefação, assertiva constatada com a análise da água dos velhos reservatórios que comprovavam sua inteira potabilidade. ${ }^{170}$

De acordo com o relatório da R.A.E., em São Paulo, tínhamos também um exemplo flagrante da auto depuração exercida pelo fator tempo que confirmava essa hipótese: "o açude velho do Ypiranga, de fraca profundidade, inteiramente abandonado, ha muitos annos, situado em um Valle baixo, tendo habitantes e pastos a montante, apresenta perennemente agua de bôa qualidade". 171

A filtração, complemento exigido para o aproveitamento das águas dos lagos artificiais, e em geral de todas as águas de superfície, foi objeto de estudos da R.A.E. que procedeu a uma série de testes e análises comparativas para determinar os procedimentos tendentes a assegurar a qualidade da água que os paulistanos beberiam.

Nesse sentido, a Repartição de Águas e Esgotos tomou um conjunto de providências para tornar a água própria para o uso doméstico e, para tanto, encetou experiências com a filtragem em filtros lentos de areia, aeração, auto depuração exercida pelo fator tempo e o provável desaparecimento de matérias orgânicas que surgiam com a fermentação, o combate da estagnação por meio de circulação contínua e o renovamento periódico do volume de água.

Após alguns meses, novos testes foram feitos para se saber se fora obtida a água "imaculada e imaculável" como dizia IMBEAUX, 1943, ${ }^{172}$ que a população consumiria, tal como ocorrera em Nova York, Boston, São Francisco em algumas cidades do Japão e em outras espalhadas pelo mundo.

De acordo com a mensagem enviada ao Congresso Legislativo do Estado, em 1911, "a julgar pelas observações feitas até então, é de suppor que não fiquem perdidas as obras executadas de construcção de barragens para a formação de lagos artificiaes que devem constituir reservas para assegurar o funccionamento normal das linhas aductoras durante os periodos das sêccas. "173

Entretanto, a contribuição desses reservatórios para o abastecimento foi relativa, uma vez que as águas do Engordador somente foram utilizadas como meio

\footnotetext{
${ }^{170}$ Ibidem, p.23.

${ }^{171}$ Ibidem, p.23.

${ }^{172}$ In BRITO, Sarturnino Francisco de. Abastecimento de Águas. Obras Completas de Saturnino de Brito. Vol.III, Ed. Imprensa Nacional, Rio de Janeiro, 1943, p.56.

${ }^{173}$ Mensagem enviada ao Congresso Legislativo do Estado de São Paulo, a 14 de julho de 1911, pelo presidente do Estado. São Paulo, 1911, p.38.
} 
de garantir o funcionamento normal da bomba a vapor instalada em 1904, ${ }^{174}$ operando em períodos de estiagem prolongada e como recurso para manter a pressão dos encanamentos quando as águas eram conduzidas para a caixa d'água do Gonçalves e daí para o reservatório da Avenida no centro de São Paulo.

O lago artificial do Guaraú, que no dizer do Diretor da R.A.E. era um recurso indispensável e cuja ausência causaria um sério transtorno no fornecimento de água $^{175}$, nunca foi utilizado, em virtude dos resultados negativos das análises de potabilidade, o que levou as autoridades a aproveitarem apenas das águas do córrego, o que na verdade já era feito desde 1894, antes da construção da barragem que formava o lago, em razão dessas águas terem sido sempre consideradas de boa qualidade.

O engenheiro Whitaker, porém, apresentou uma outra versão: para ele, a barragem, embora concluída, nunca foi posta em serviço por se terem verificado infiltrações em sua fundação, ${ }^{176}$ tese impossível de ser comprovada em razão da destruição total do reservatório para a construção da Estação de Tratamento do Guaraú.

Em 7 de Maio de 1929, o município de Guarulhos abriu mão do Cabuçu, através do convênio Guarulhos - Governo do Estado de São Paulo.

A represa do Cabuçu funcionou por mais de 60 anos, sendo desativada pela Companhia de Saneamento Básico do Estado de São Paulo, (SABESP), quando entrou em operação o atual sistema Cantareira, na década de 1970.

Em 1992 foi concedida outorga ao município de Guarulhos dos mananciais do Cabuçu, Barrocada e do Tanque Grande por 30 anos, e, em 1999, foram iniciados os estudos para reativação do uso da barragem, desta vez para contribuir no abastecimento de parte daquele município, região de grande densidade demográfica que engloba o Aeroporto Internacional de Cumbica.

Hoje, a represa do Cabuçu, com capacidade de $1.776 .000 \mathrm{~m}^{3}$ de armazenamento e uma vazão firme de 371 litros por segundo, tem uma estação de tratamento de água à jusante da barragem e é administrada pelo Serviço Autônomo

\footnotetext{
${ }^{174}$ FONSECA, Filomena Pugliese. Dissertação de Mestrado: Equipamento do Engordador: Testemunho Arqueológico Industrial da Captação de Água na Cidade de São Paulo. S.P., 2003, p.43.

${ }^{175}$ Relatório da Repartição de Águas e Esgotos de São Paulo, de 1907/1908, apresentado pelo Diretor, ao Secretário da Agricultura, Typographia Brazil-Rothschild \& Co.São Paulo, 1908, p.21.

${ }^{176}$ WHITAKER, Plínio Penteado. Abastecimento de Água da Cidade de São Paulo. In Revista de Engenharia no 50, Vol. V., Ed. Técnica Ltda, São Paulo, 1946, p.67.
} 
de Água e Esgotos de Guarulhos (SAAE), abastecendo assim nesse município, uma população aproximada de 125.759 habitantes, segundo dados de julho de 2007. 


\section{CONVERGINDO PARA A ARQUEOLOGIA DO CABUÇU}

Obras públicas não são apenas monumentos isolados na natureza, mais do que isso formam um tecido que suporta e torna possíveis as relações sociais, e têm um valor arqueológico, simbólico, estético, histórico, tecnológico e funcional, que nos obrigam a um preservação inteligente. ${ }^{177}$ (GARCIA, 1990)

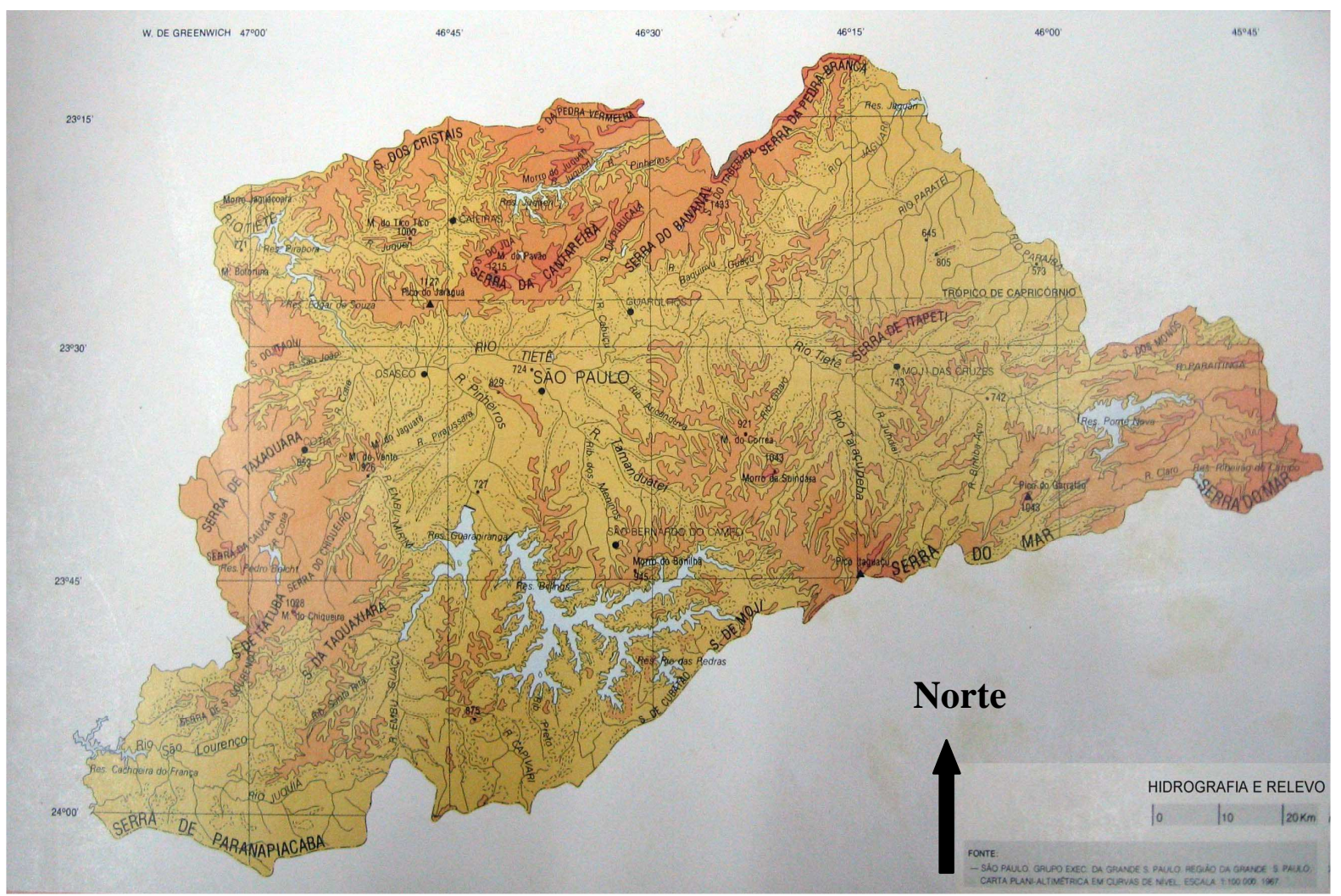

São Paulo Secretaria de Economia e Planejamento.Coordenadoria de Ação Regional.Instituto Geográfico e Cartográfico. I.G.C.1990.

A Serra da Cantareira ocupa a porção Norte do Município de São Paulo. A orientação geral dessa serra é Leste-Oeste, delimita os Municípios de Guarulhos e São Paulo, e suas vertentes voltadas para Sul-Sudeste estão no lado Paulistano.

No compartimento da bacia sedimentar de São Paulo, o principal rio o Tietê recebe as águas dos rios Pinheiros, Tamanduateí, Aricanduva, e os da vertente sul da Serra da Cantareira: o Cabuçu de Baixo e o Cabuçu de Cima.

Com 27.200m de extensão, o Cabuçu de Cima nasce na Serra da Cantareira, e drena uma área de 130 quilômetros quadrados. Sua bacia hidrográfica, a maior da

\footnotetext{
${ }^{177}$ GARCIA, M. L. La Obra Publica, Investigacion Y Pratica. In I Encontro Nacional sobre o Património Industrial. Vol. II. Ed. Coimbra Ltda. Coimbra, 1990, p.281.
} 
margem direita do rio Tietê, localiza-se na zona norte da Região Metropolitana de São Paulo, entre a barragem da Penha e a foz do rio Pinheiros. 


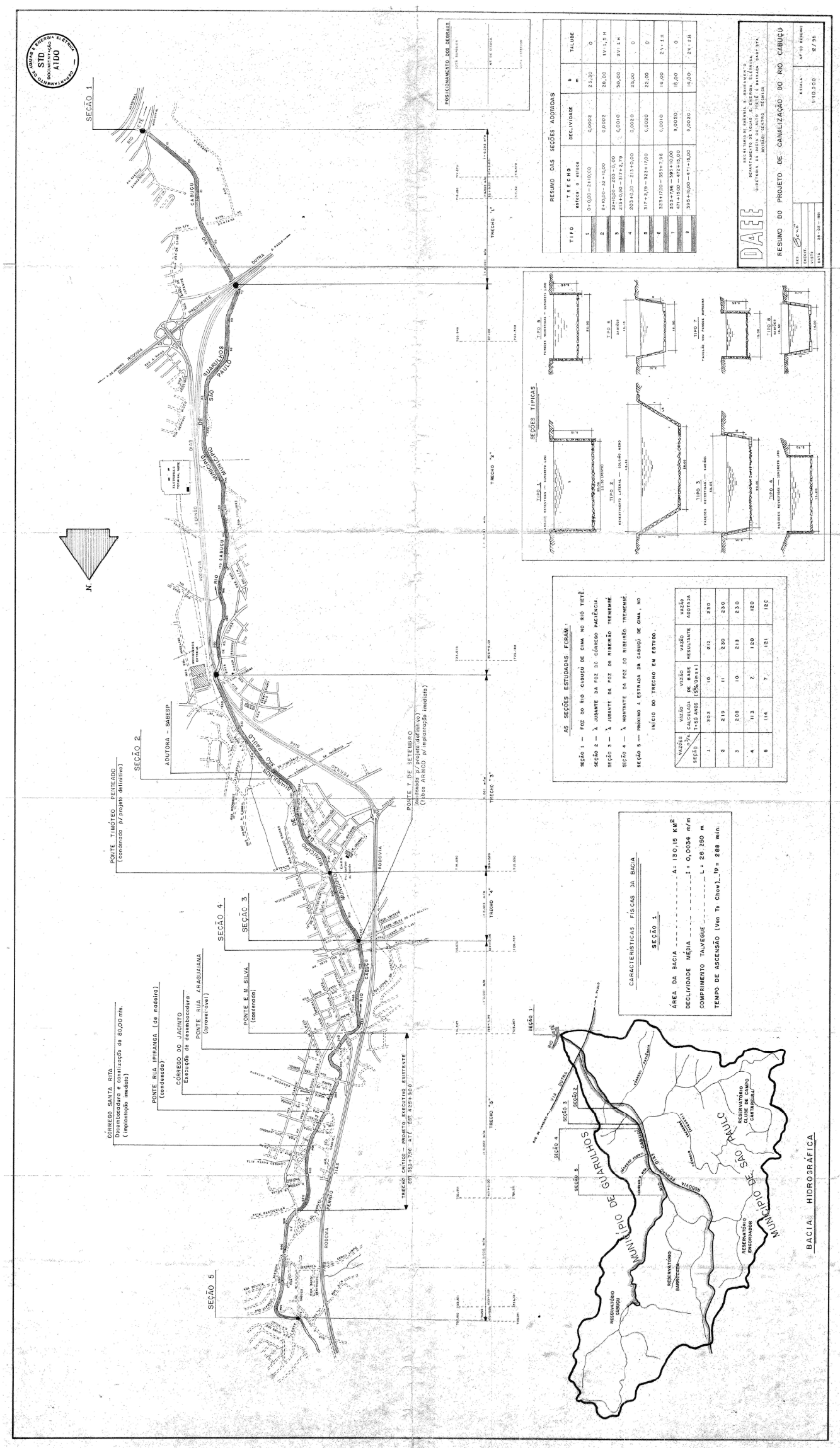

Mapa de distribuição geográfica do Rio Cabuçu 


\subsection{Localização e acesso}

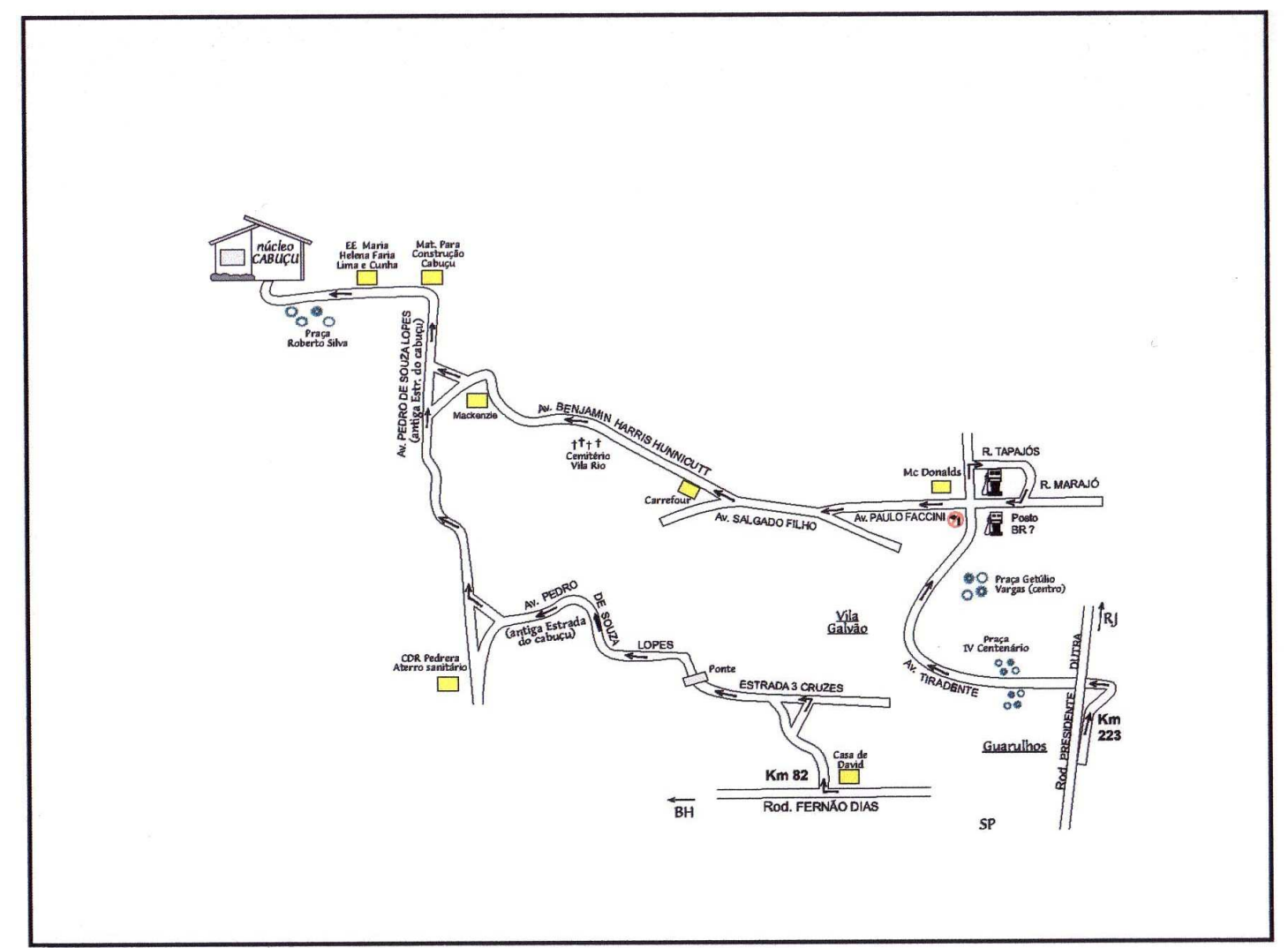

Mapa de acesso ao Núcleo Cabuçu

\subsection{Origem do nome}

De acordo com Silveira Bueno, em seu "Vocabulário Tupi guarani-português", Cabuçu-grafia correta Cabussú é o nome de um rio nos arredores de São Paulo, de caba=vespa e ussú=grande, portanto, significaria "vespa grande", o "marimbondo graúdo", o "vespão", o "trovão". 178

Porém, João Mendes de Almeida em "Diccionario Geograhico da Província de S. Paulo", assim define:

Caboçu (Cabuçu), afluente do rio Guapira, pela margem esquerda: nasce nos morros denominados Perucaia, e corre entre os Municípios S.Paulo e da Conceição dos Guarulhos. Caboçú, corruptela de guàà-buçú, enseada larga. De guàà, enseada alagadiço, buçú, largo grande, o mesmo que uçú, ou seja, alagadiço grande. ${ }^{179}$ (ALMEIDA, 1902)

\footnotetext{
${ }_{178}$ BUENO, S. Vocabulário Tupi guarani-português, Ed. Nagy Ltda, 2ª .Ed, São Paulo, 1983, p.34.

${ }^{179}$ ALMEIDA, J..M. Diccionario Geographico da Provincia de São Paulo. Typ. A Vap. Espindola, Siqueira \& Comp. SP, 1902, p.27.
} 
Para outros autores significa árvore grande de "caa"=árvore e "ussu"= grande.

\subsection{Adução do Cabuçu: um divisor de águas}

Partes do sistema de abastecimento de água, as adutoras são constituídas pelo conjunto de encanamentos, peças especiais, e obras de arte, destinadas a promover a circulação da água entre os diversos órgãos desse sistema, das fontes de abastecimento de água bruta, a captação, aos sistemas de tratamento, destes para os reservatórios e daí para a rede de distribuição.

A adução pode ser feita por gravidade, a energia para o escoamento provém da diferença de nível entre as partes do complexo do abastecimento; por recalque, feita por uma conjunto elevatório; ou mista, parte por gravidade, parte por recalque.

Muitas vezes não possuem derivações, entretanto, existem casos em que da adutora principal partem ramificações, (subadutoras), que ligam diretamente as estações de tratamento aos reservatórios, que alimentam as linhas de consumo, ou às vezes, fazem a ligação entre dois reservatórios de distribuição entre si.

De diferentes espécies de materiais e métodos de fabricação, elas podem ser: de ferro fundido, de aço, de plástico PVC, de poliéster com fibra de vidro, de concreto simples e tubos de concreto armado, que resistem a pressões elevadas, e são utilizados em adutoras de grande diâmetro.

Desse material, o cimento armado, como o concreto era chamado até 1920, foram feitas as adutoras que conduziam as águas do ribeirão do Cabuçu, e cujo emprego foi pioneiro, na história da engenharia brasileira.

Segundo o relatório enviado pela Secretaria da Agricultura ao Presidente do Estado, Jorge Tibiriçá, "para a addução das aguas do Cubuçú, foi como sabeis adoptado o aqueducto em cimento armado, construcção que foi levada a effeito com o maior successo e veiu a constituir um bello exemplo de obra da engenharia nacional". 180

Desde 1896, já se delineavam as obras que iriam captar e aduzir as águas do vales dos rios Cubuçu e Barrocada, conforme se depreende do relatório da Secretaria Agricultura, apresentado ao Presidente do Estado, Campos Salles, sem

\footnotetext{
${ }^{180}$ Relatório da Secretaria dos Negócios da Agricultura, Commercio e Obras Publicas do Estado de São Paulo, de 1907, apresentado ao Presidente do Estado, pelo Secretario da Agricultura.Typographia Brazil de Rothschild \& Co., 1908, p.XXX.
} 
entretanto cogitar-se da construção da barragem, para formação do lago artificial do Cabuçu, que teria início dez anos depois.

"Na planta dos estudos vem figurada a linha passando do Valle da Barrocada ao de Cabuçu onde se encontram os vertedores números 1 e 12, medindo em 24 horas 10.966.476 litros. Esses vertedeores acham-se em cotas variaveis, não sendo, portanto, fácil determinar exactamente o volume de suas aguas, sem mais completos e detalhados estudos. Não obstante, parece que sem maiores difficuldades poderão ser trazidas ao reservatório do Cambucy, reunidas ás do Machado, com um volume de cerca de 8.000 .000 de litros". ${ }^{181}$

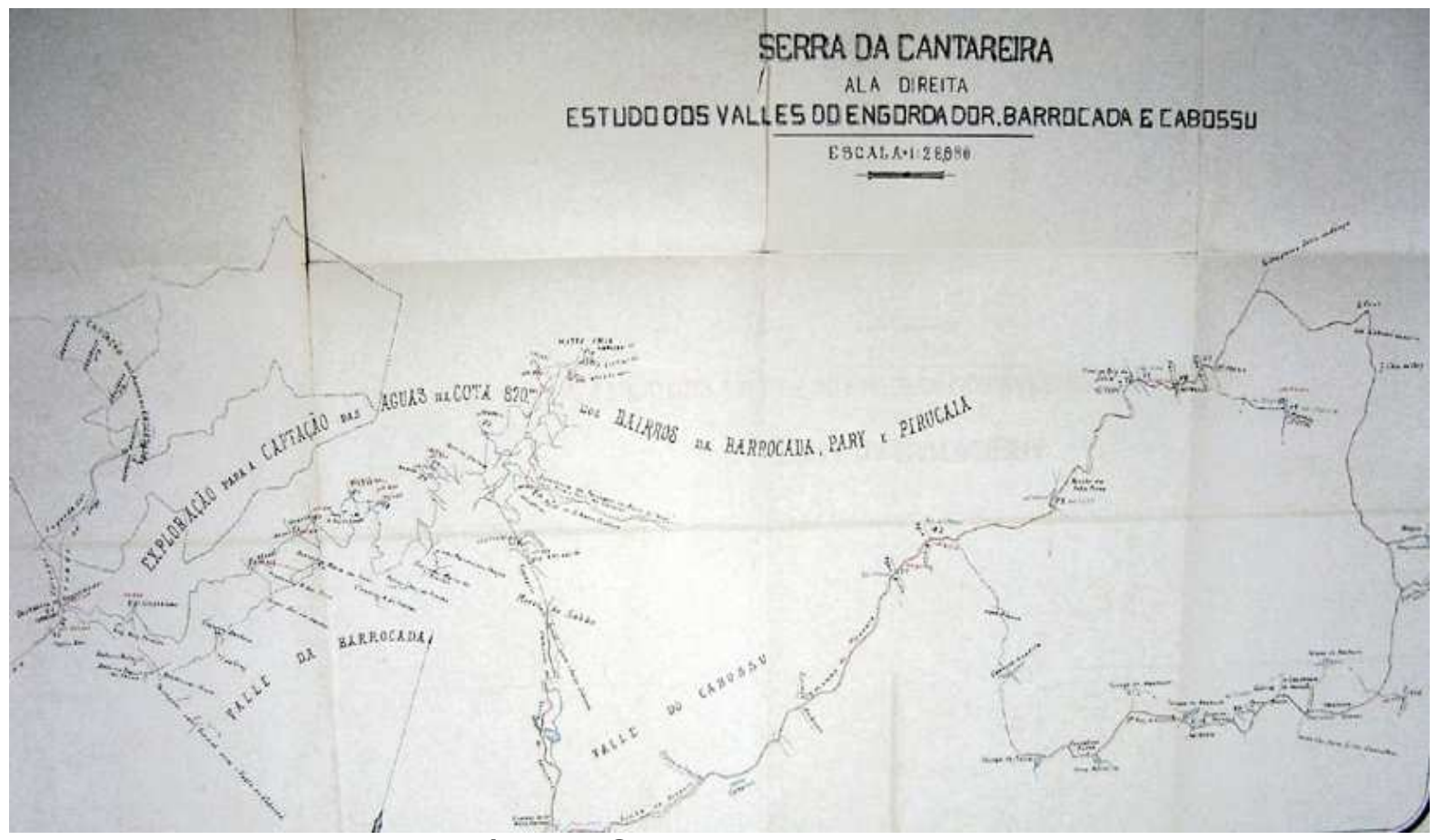

Foto do relatório da Secretaria da Agricultura de 1896

Porém, somente alguns anos mais tarde, a Comissão de Obras Novas de 1905, organizou um plano de reforço para o abastecimento de água das várias zonas altimétricas redefinidas, do qual faziam parte o projeto de captação e adução dos rios Cabuçu de cima e Barrocada, com canalização adequada para recebê-los, e a construção dos lagos artificiais, do Engordador e do Guaraú, já citados, procurando dessa forma, aumentar o volume do líquido para as zonas altas da

\footnotetext{
${ }^{181}$ Relatório da Secretaria de Estado dos Negócios da Agricultura, Comércio e Obras Públicas, de 1896, apresentado ao Presidente do Estado, pelo Secretário da Agricultura. Typographia Espindola, Siqueira \& C.São Paulo, 1897, p.239.
} 
cidade, durante o período de estiagem, e ao mesmo tempo, tentando preservar a pureza dos mananciais da serra da Cantareira.

A zona baixa da cidade, compreendida entre as cotas $720 \mathrm{~m}$ e $735 \mathrm{~m}$, com os bairros do Brás, Bom Retiro Luz, e Mooca, seria tributária do reservatório do Cabuçu, cujo principal objetivo era proporcionar um serviço de utilidade pública, o abastecimento de água em condições aceitáveis para o consumo desse contingente populacional, já bastante expressivo nos primeiros anos do século $\mathrm{XX}$, e cuja saúde dependia principalmente da quantidade e qualidade da água que consumiam.

A R.A.E. procurava, na impossibilidade de obter captações subterrâneas, melhorar as superficiais, com a desapropriação das cabeceiras dos mananciais e córregos, protegendo-os da contaminação, embora suas águas, ainda assim, tivessem que passar por um tratamento adequado.

No Cabuçu, "onde os terrenos têm pouco valor e as aguas são praticamente puras, tão puras como as que actualmente se distribúem á cidade, esse tratamento nem siquer será dispendioso, como seria por exemplo, no caso de serem aproveitadas as aguas do Tieté". 182

Foi essa uma das razões de ter sido abandonado o projeto de Rebouças ${ }^{183}$, de se elevar as águas do Tietê para a zona baixa, e não se cogitou da captação dos mananciais altos, que pudessem por gravidade, abastecer qualquer zona da cidade.

Entre 1905 e 1906, quando eram diretores da Repartição de Águas e Esgotos, Augusto Figueiredo e Arthur da Motta e o chefe da Comissão de Obras Novas, Luiz Betim Pais Leme, para reduzir a escassez de água da última zona, e democratizar o abastecimento, foi posta em prática, a primeira etapa da adução do rio Cabuçu de Cima, na cota 750, com uma contribuição de mais de 40.000.000 de litros/dia para os bairros desta zona.

\footnotetext{
${ }^{182}$ Relatório da Secretaria dos Negócios da Agricultura, Comércio e Obras Públicas do Estado de São Paulo, de 1905, apresentado ao Presidente do Estado, pelo Secretário da Agricultura. Typographia Brasil de Rothschild \& Co.São Paulo, 1906, p.226.

${ }^{183}$ Engenheiro José Pereira Rebouças, diretor da Repartição de Águas e Esgotos desde sua fundação em 1893 até 1898.
} 


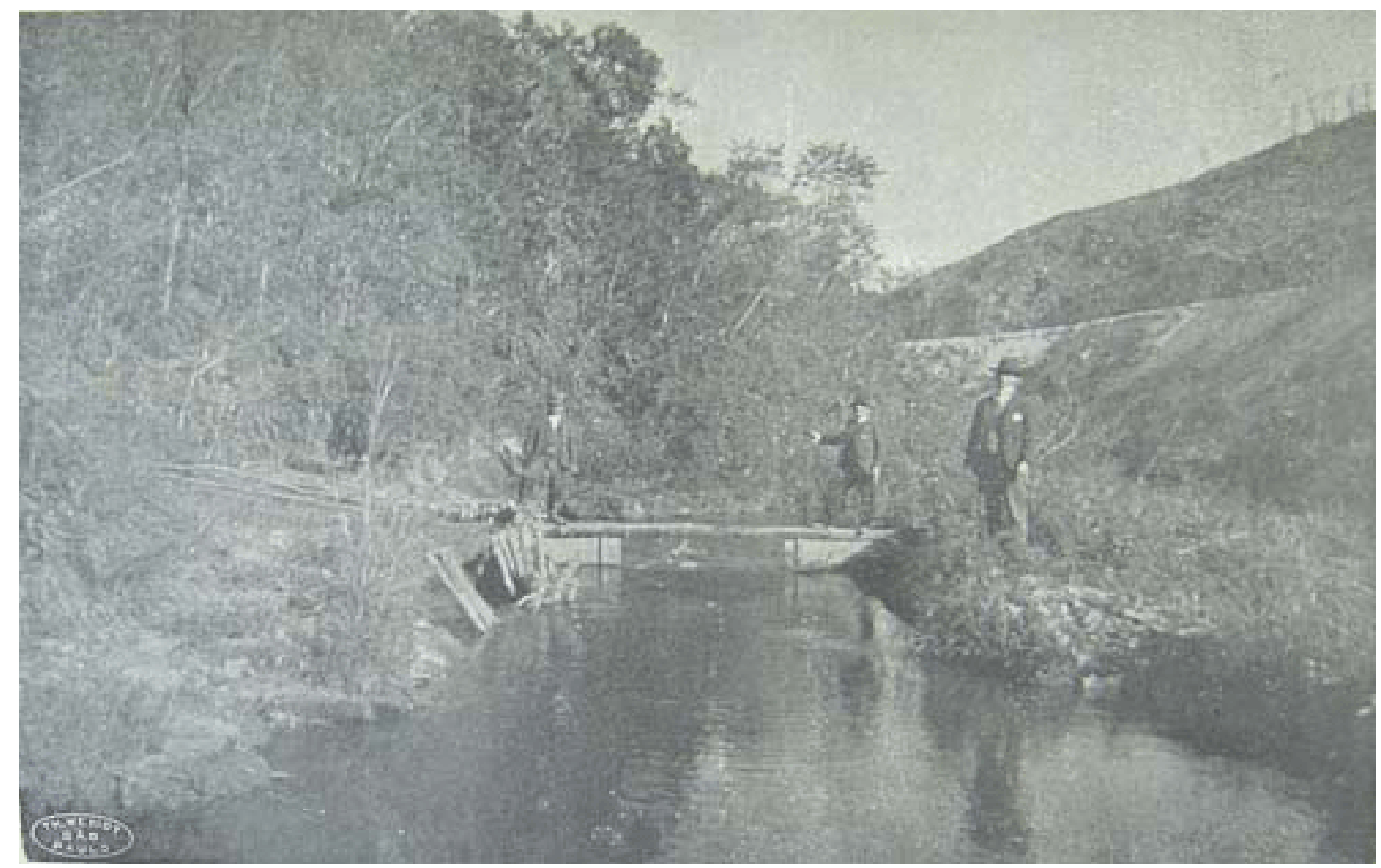

Ribeirão do Cabuçu - ponto de captação, 1905

No relatório de 1905, do engenheiro chefe da Comissão de Obras Novas enviado ao Secretário de Estado da Agricultura, assim foi descrita a obra:

"A adducção das águas do Cabuçu é talvez a mais importante do Brasil. O volume adduzido é de 500 litros por segundo, de sorte que o abastecimento actual vae ser duplicado. A zona baixa, que é a mais vasta e que corresponde mais ou menos a metade da cidade, absorverá toda essa água, emquanto que as águas actuaes, que abasteciam a parte baixa, passarão a abastecer as zonas altas, augmentando também o volume que ellas recebem actualmente." ${ }^{184}$

Segundo o mesmo relatório, as canalizações para essa adução já estavam em curso em 1905, e atravessavam os dois braços do rio Tietê e o Tamanduateí, por meio de três pontes de concreto armado, feitas pelo sistema Matrai. ${ }^{185}$

\footnotetext{
${ }^{184}$ Relatório da Secretaria dos Negócios da Agricultura, Comércio e Obras Públicas do Estado de São Paulo, de 1905, apresentado ao Presidente do Estado, pelo Secretário da Agricultura. Typographia Brasil de Rothschild \& Co.São Paulo, 1906, pp.225/226.

${ }^{185}$ Do tipo Matrai, é a construção de ponte suspensa com cabos de aço cobertos de cimento armado; estes cabos eram de duas polegadas de diâmetro.
} 


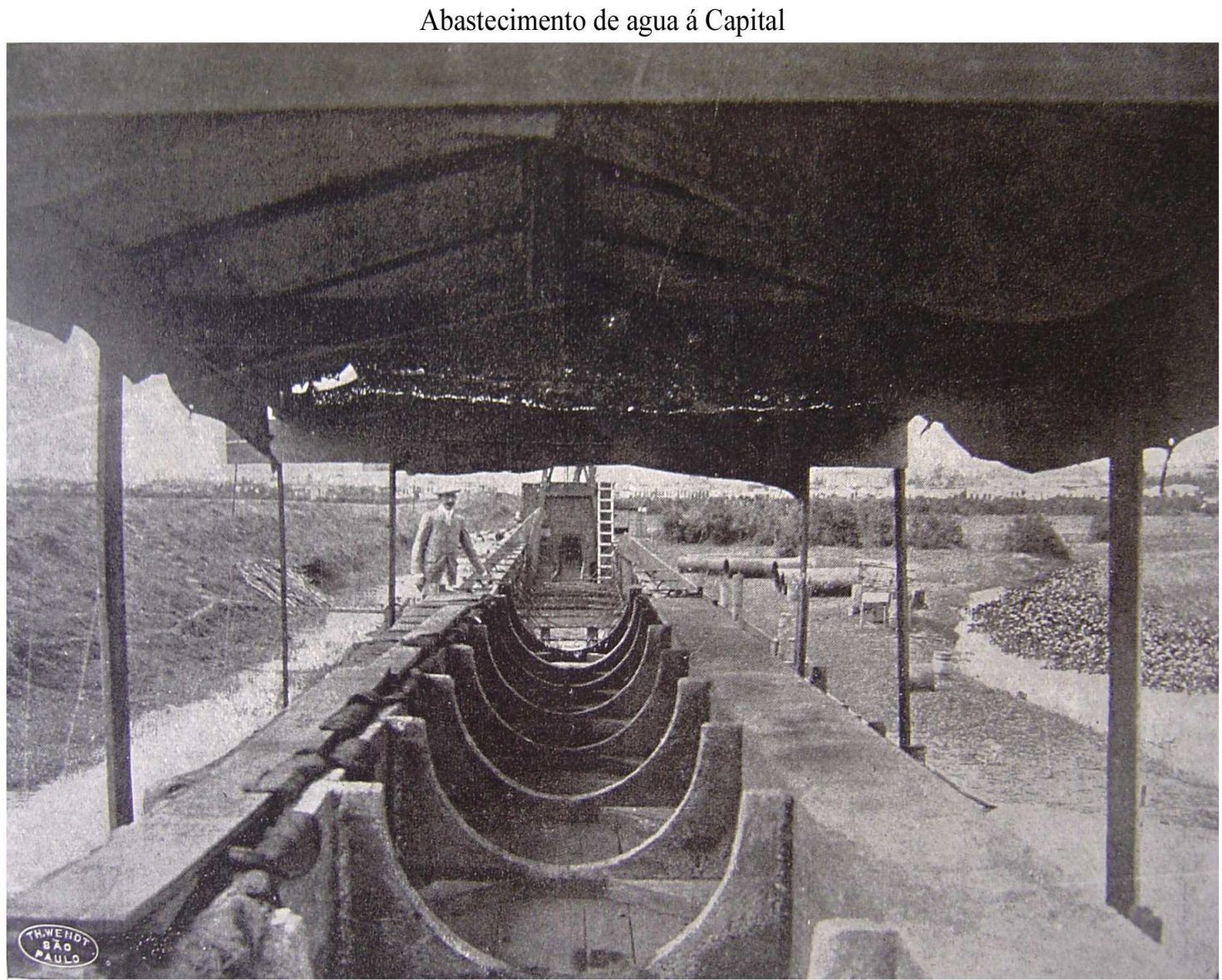

Parte superior da ponte de cimento armado sobre o Tietê para a passagem de tubos de $1 \mathrm{~m}$.

Foto de 1906 in Relatório da R.A.E., de 1906/1907. Acervo do Arquivo do Estado de São Paulo

A adutora, com uma extensão de quase $17.000 \mathrm{~m}$, e uma pressão que variava entre 5 a $40 \mathrm{~m}$, foi construída em linha mista, composta por 28 aquedutos de cimento armado em forma de dupla elipse e 28 sifões, cujos tubos tinham um metro de diâmetro, e uma carga hidrostática de $27 \mathrm{~m} .{ }^{186}$

O grande eixo da elipse da base, coincidia com o pequeno eixo da elipse, formando a abóbada, obtendo-se assim, uma base larga para a distribuição das pressões sobre o solo, e uma abóbada mais elevada que permitia visitas a seu interior.

\footnotetext{
${ }^{186}$ Parte da hidromecânica que estuda a pressão e o equilíbrio dos líquidos e dos gases que se submetem a ação da gravidade.
} 


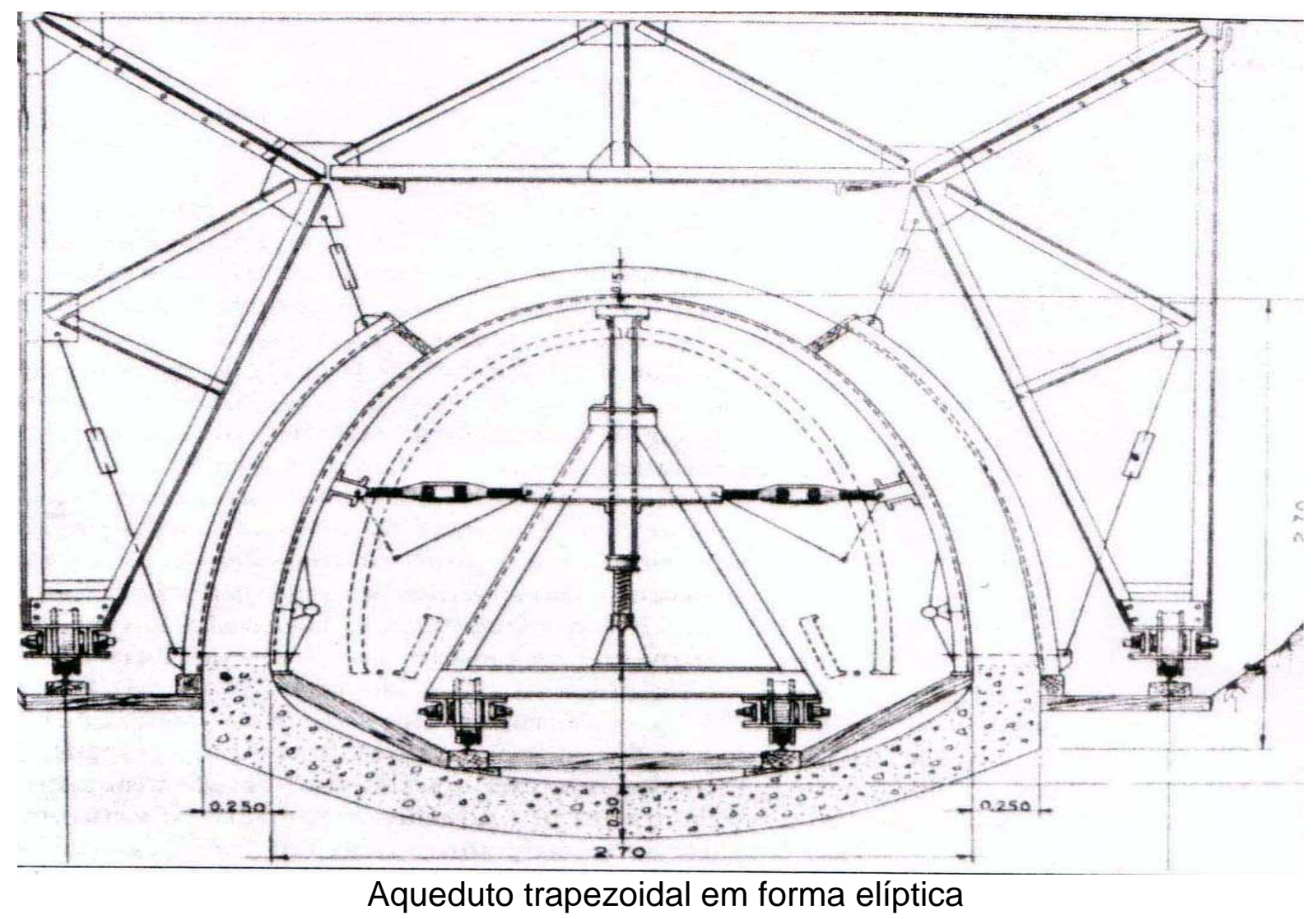

Adducção do Cabuçu

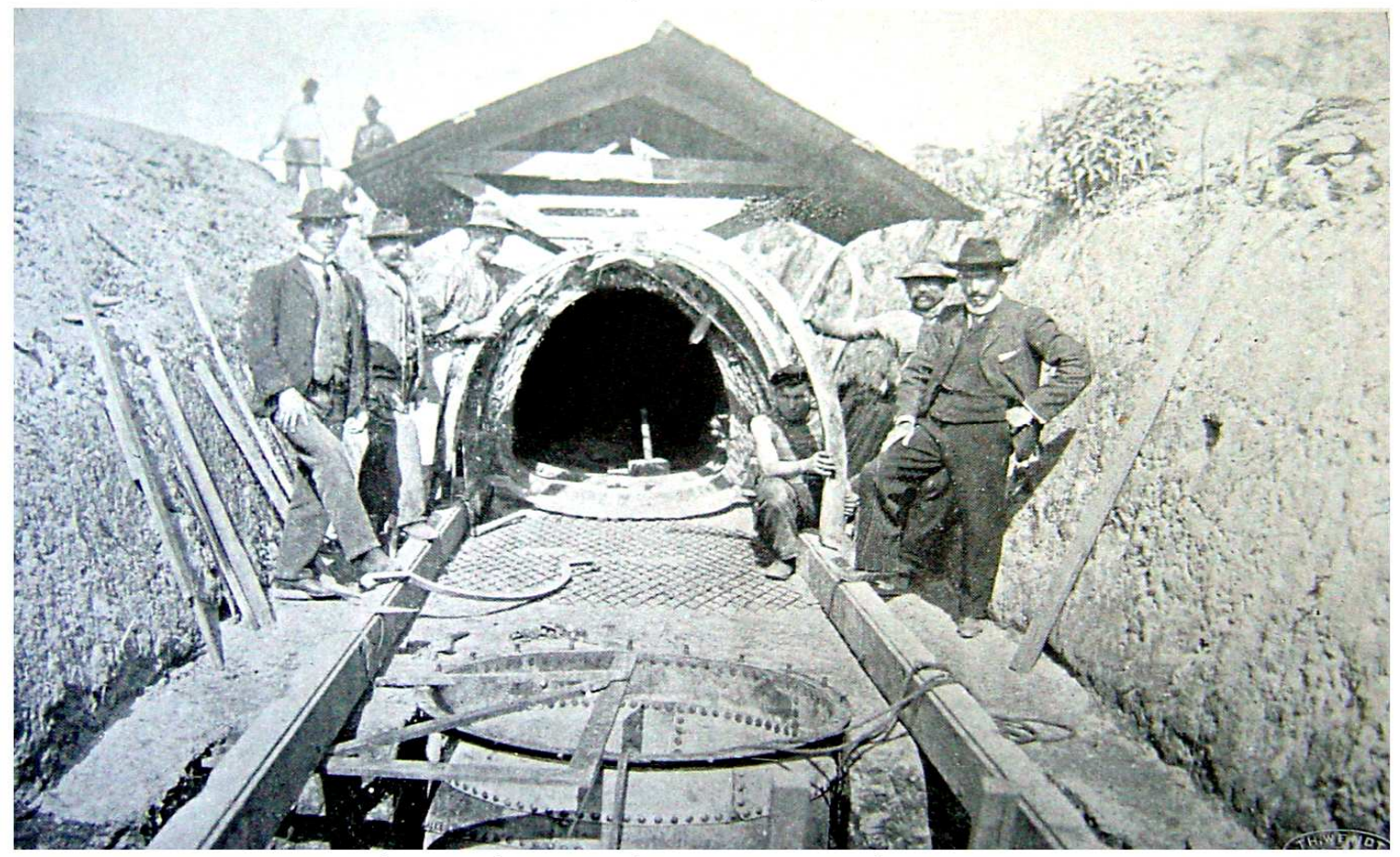

Ligação de um syphão com o aqueducto

Foto 1906 in Relatório da R.A.E. de 1906/1907. Acervo Arquivo do Estado de São Paulo. 
Com capacidade máxima de 500 litros por segundo, ou 43.200 .000 em 24 horas, a adutora foi projetada para transportar os volumes dos ribeirões do Cabuçu, e Barrocada, (aduzido posteriormente em 1912), e as resevas acumuladas pela barragem de concreto, que estava sendo erigida em um estreitamento brusco do vale do Cabuçu, a fim de garantir a efetividade desse volume, com uma contribuição de 35.000.000 de litros/dia, e regular a vazão da linha adutora.

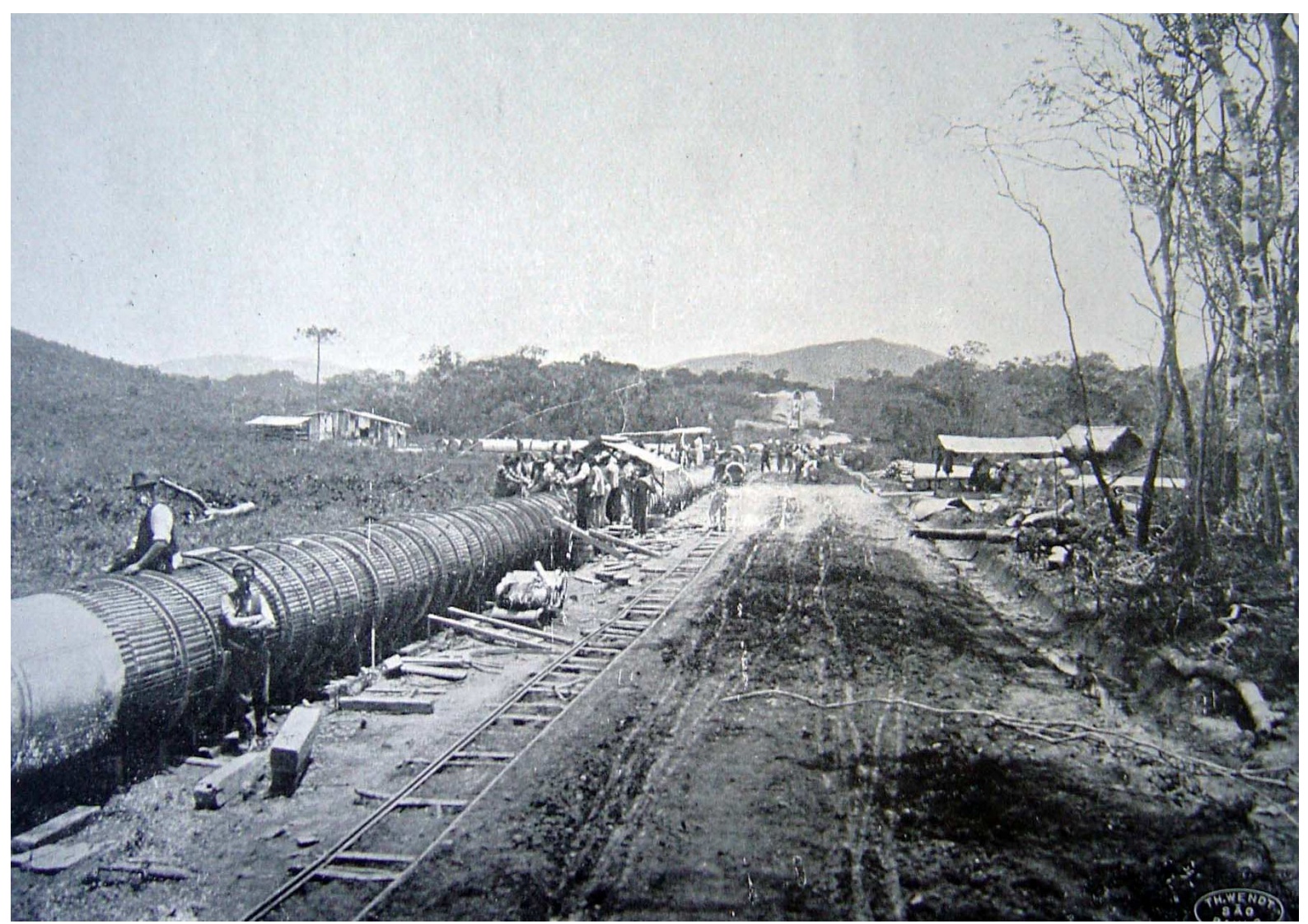

Sifão com 1 Km de extensão da adutora do Cabuçu. In Relatório da R.A.E. de 1906.

No início de 1906, foram lavrados contratos com diversos empreiteiros, e em menos de dois meses, a Comissão de Obras Novas, construiu uma estrada de rodagem de 19 quilômetros de extensão, com três metros de plataforma, para transportar areia, cimento e ferro, o que exigiu, de acordo com o relatório da época, um movimento de terra superior a 100.000 metros cúbicos, e a edificação de numerosos pequenos pontilhões, em razão de ser o terreno acidentado, o que impedia, muitas vezes, que essa estrada acompanhasse o traçado da linha adutora. 
Até Junho daquele ano, nenhuma obra pode ser iniciada, a não ser a escavação em cortes, e a perfuração dos túneis, tendo em vista o numeroso material importado, como era o caso do cimento vindo da Inglaterra, que somente chegou ao canteiro de obras, três meses após as assinaturas dos contratos com as firmas importadoras, lavrados em Fevereiro e Março de 1906, em razão da burocracia alfandegária que criou sérios entraves ao despacho dos materiais, embora estivessem eles isentos de taxas.

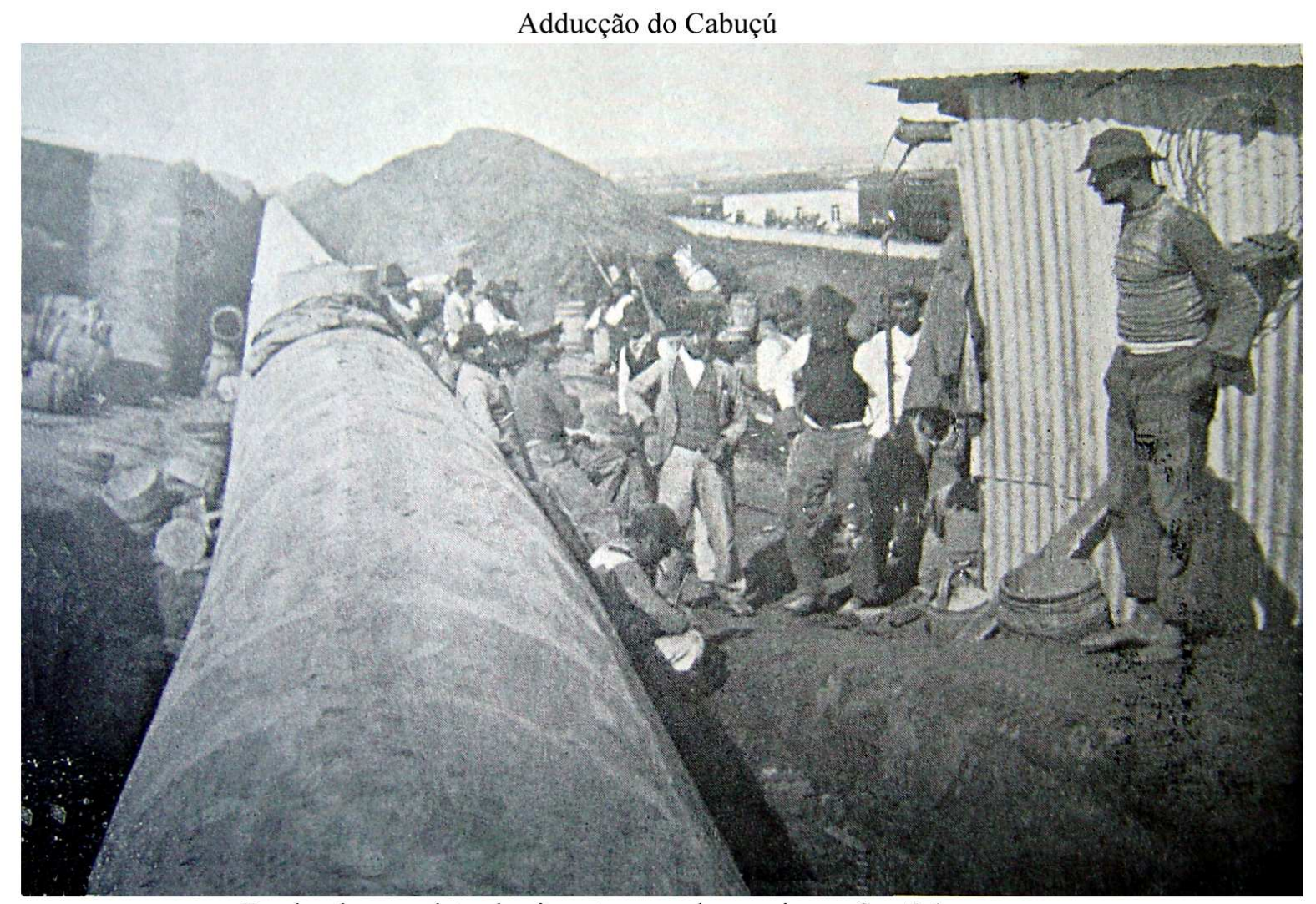

Trecho do aqueduto de cimento armado proximo a Sant' Anna

Foto de 1906 in Relatório da R.A.E., de 1906/1907. Acervo do Arquivo do Estado de São Paulo.

Betim Paes Leme, descreve em seu relatório, que nesse ínterim foi aberto um grande número de cortes e iniciada a perfuração dos túneis; quanto à do túnel de número dois, o do Tucuruvi, considerada a parte mais penosa e difícil de toda a obra, já no início foram constantes suas interrupções, em razão de medida judicial de manutenção de posse, obtida pelo proprietário dos terrenos por onde o aqueduto passaria, contra o Governo do Estado. Somente no final de 1906, depois julgado o 
mérito da ação, os trabalhos foram reencetados, levando o Diretor a acreditar que pelo andamento do serviço essa perfuração terminaria em Junho de 1907.

A seção deste túnel, segundo o Diretor, era de dimensões reduzidas, circunscrita apenas a 10 centímetros de folga do perímetro total do aqueduto, cuja parte superior construída a céu aberto, como se vê pela foto, foi transportada para o interior, por meio de uma vagoneta especial, uma vez consolidada a base do túnel por um radier ${ }^{187}$ de cimento armado em forma de calha.

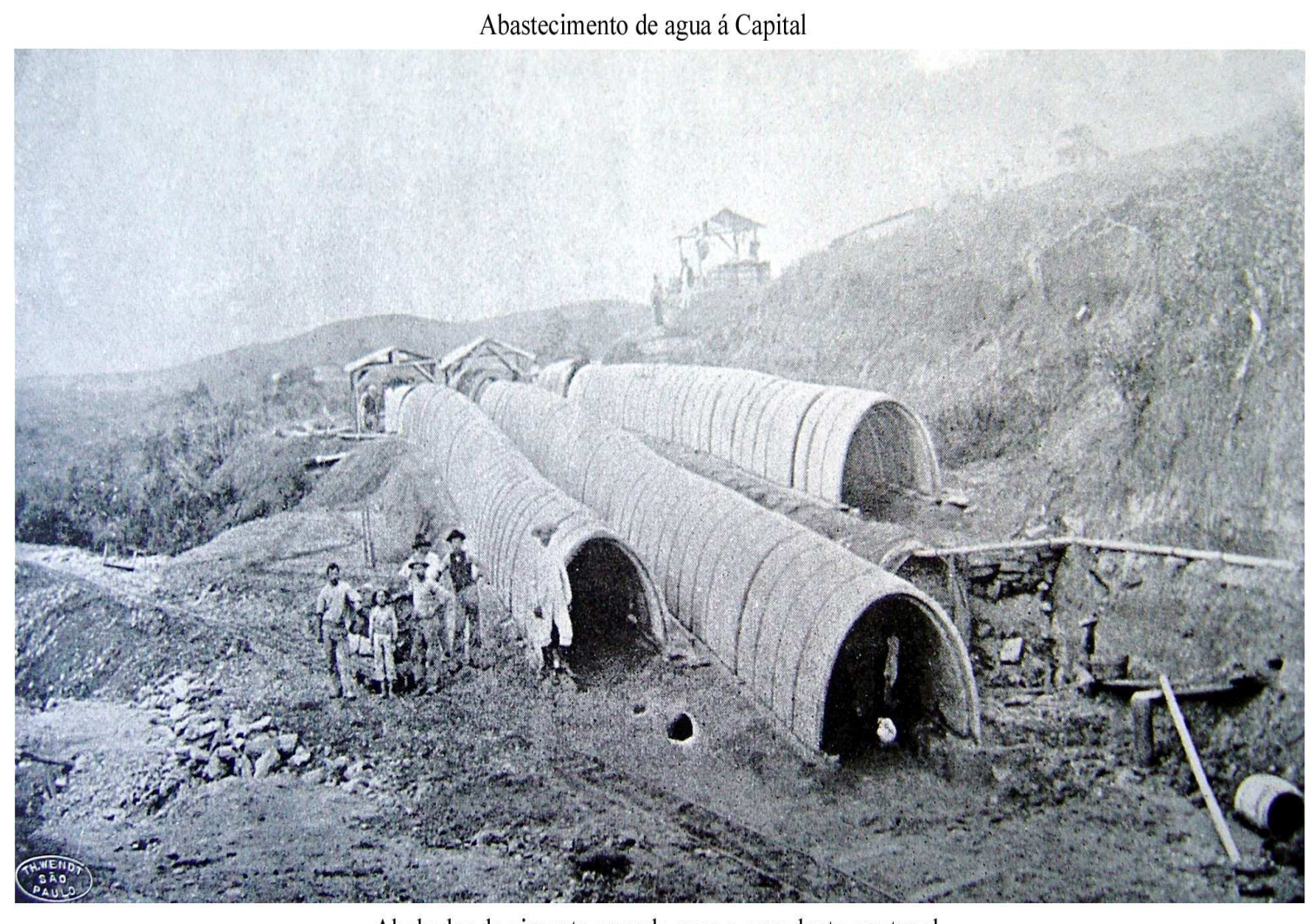

Abobadas de cimento armado para 0 aqueducto em tunel

Foto de 1906 in Relatório da R.A.E., de 1906/1907. Acervo do Arquivo do Estado de São Paulo.

Em cinco meses foram construídos, doze quilômetros de aquedutos, e três de sifões de cimento armado, o que correspondia a uma média de cem metros de linha adutora por dia de trabalho. Tal rapidez de execução, segundo os relatos da época, nunca fora atingida em nenhuma outra obra, e o que a tornou verdadeiramente notável, como técnica de engenharia, é que os terrenos onde foram construídos os

\footnotetext{
${ }^{187}$ Espécie de laje contínua de concreto armado, utilizada para estabilizar as fundações de uma obra, transmitindo as cargas da estrutura, pilares ou paredes, para o terreno.
} 
aquedutos estavam situados, na maior parte, em encostas escarpadas de difícil acesso, e todos os sifões com grandes extensões, foram colocados em terrenos pantanosos, cuja drenagem e fixação exigiu quase sempre, o rebaixamento dos córregos. Esses aquedutos com 12.523,70m, que atravessaram em túnel os morros do Pedregulho, com 242,70m, do Tucuruvi, 614m, e o de Santana com 220m, somados a outros sifões, de $3.749,90 \mathrm{~m}$, de extensão, perfaziam os $16.272,70 \mathrm{~m}$ de linha adutora.

Todo sistema de abastecimento, desde a represa até a rede de distribuição, foi um sucesso da técnica e da engenhosidade dos pioneiros do concreto armado, embora tivesse havido contratempos, provocados pelo metal empregado no revestimento dos condutos forçados, que tiveram as junções soldadas, sem resultado satisfatório, ocasionando grandes vazamentos, o que foi posteriormente devidamente sanado.

A centenária adutora, inaugurada a 1ํ de setembro de 1907, e considerada para época uma grande obra, toda em concreto armado, foi a parte mais importante dos encargos da Comissão de Obras Novas.

\subsection{Trabalho de campo}

Consistiu em se registrar, fotograficamente, alguns locais onde essa adutora ainda é visível, suas coordenadas U.T.M., e seu estado de conservação, uma vez que foi desativada há mais de 30 anos, quando entrou em funcionamento o Sistema Cantareira atual.

Lamentavelmente, não foi possível acompanhar seu traçado, desde o ponto de captação, no rio Cabuçu, por não terem sido encontradas plantas da época de sua construção, e em razão da própria configuração da cidade, que cem anos depois, modificada por tantos planos viários, enterrou para sempre grande parte dos vestígios dessa obra, considerada de vanguarda, da engenharia paulistana do começo do século $X X$. 


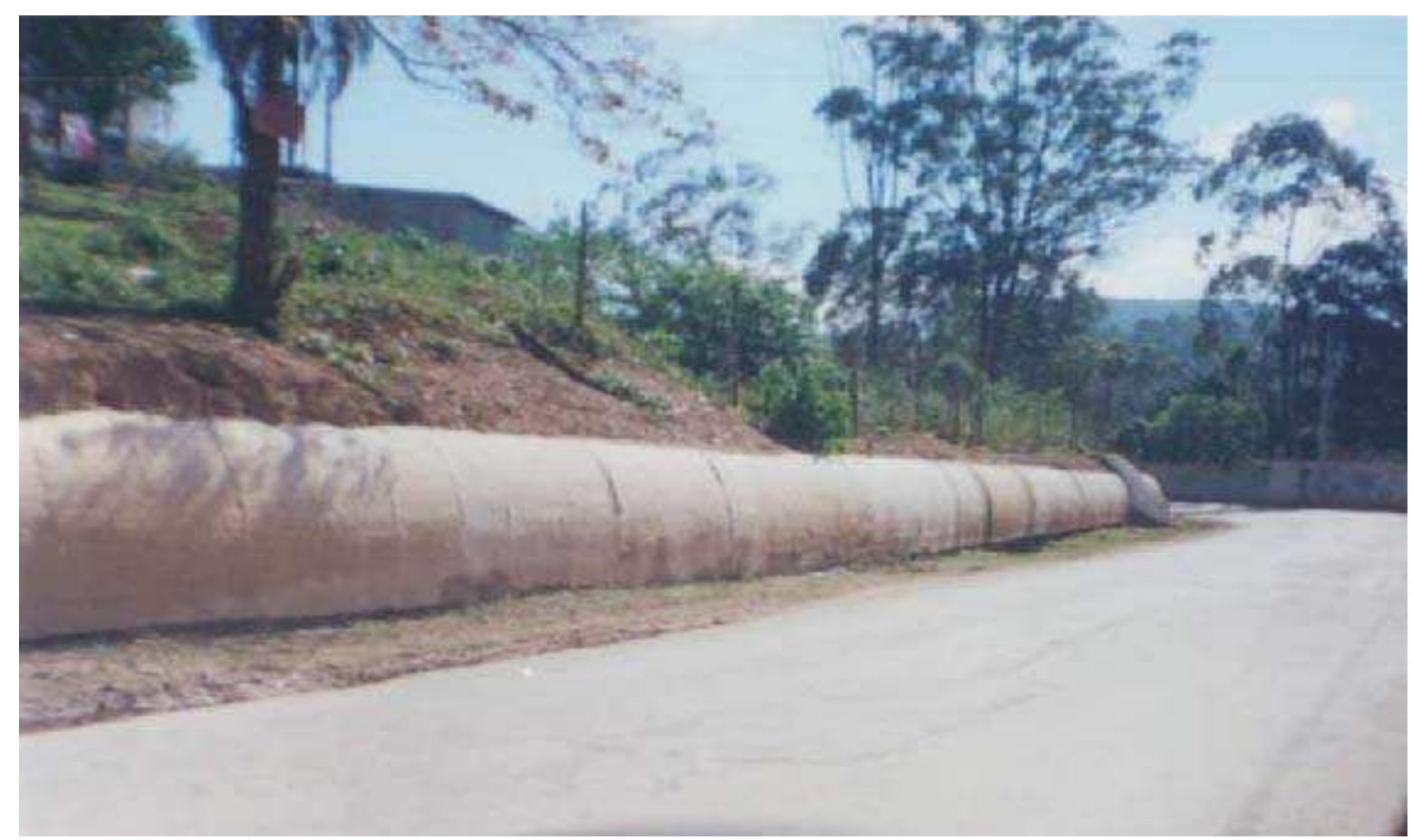

Foto da adutora na Estrada do Cabuçu, do acervo particular da Empresa Hagaplan Engenharia, 1990.

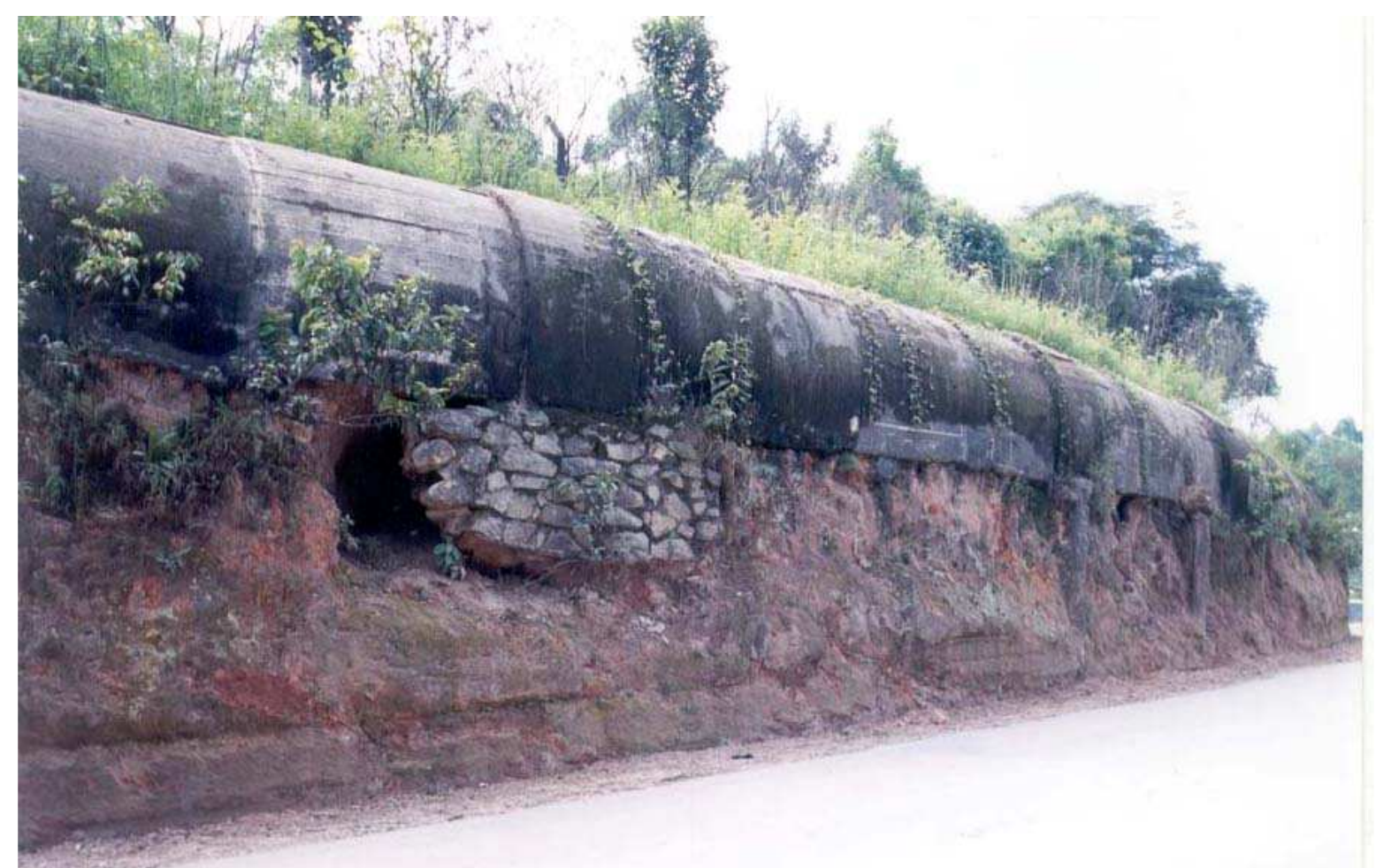

Foto da adutora, acervo Plínio Thomaz, década de 1990. 


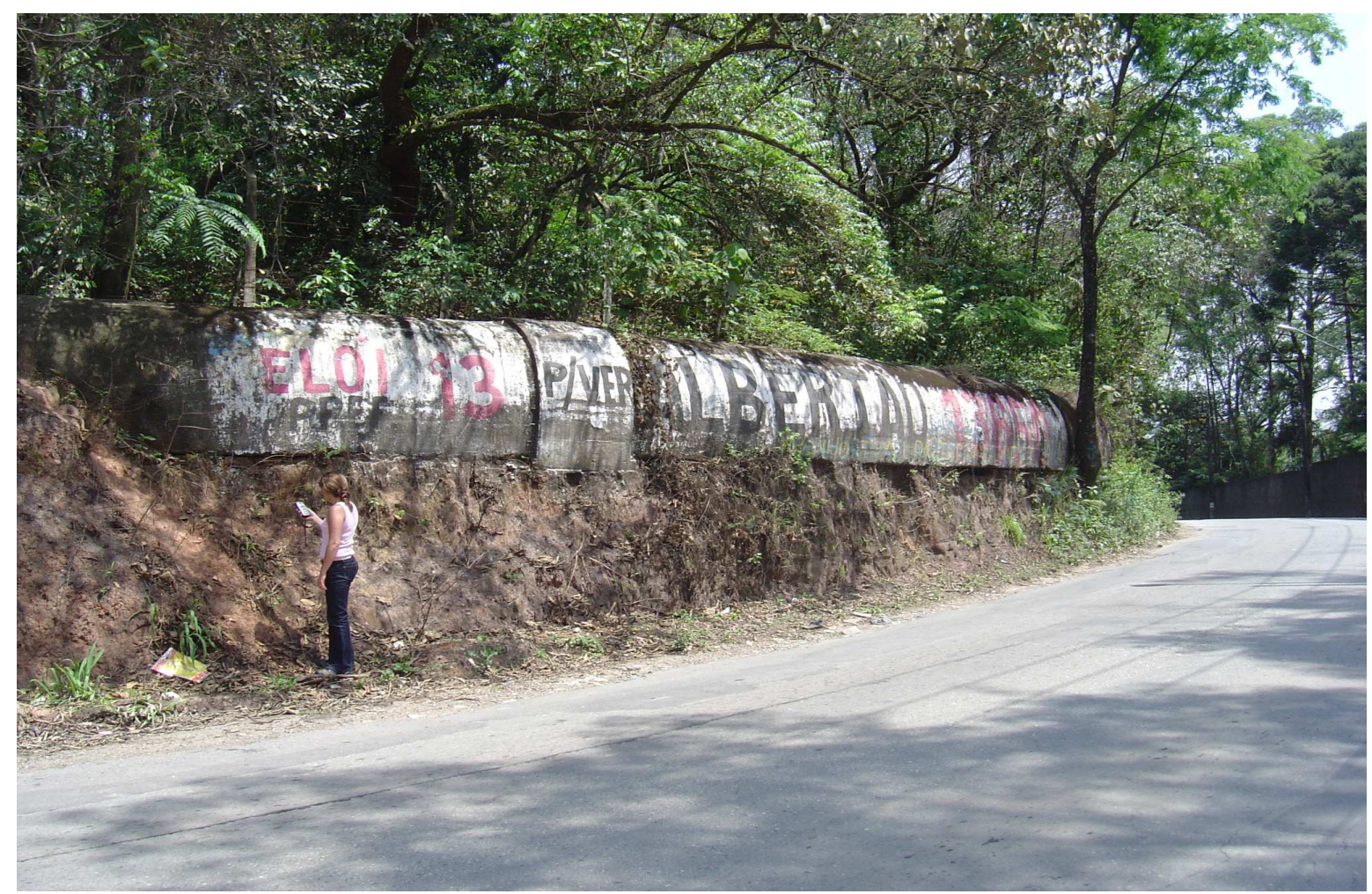

Foto da adutora no mesmo ângulo, outubro de 2006.

Um dos segmentos iniciais da adutora, fica na Estrada do Cabuçu, Município de Guarulhos, São Paulo, próximo à saída do reservatório, do Cabuçu, de onde ela partia conduzindo suas águas, em direção à caixa d'água do bairro da Luz, e daí para a rede distribuidora. Com se pode notar, foi acentuado o processo de deterioração, entre os anos que separam as duas fotos, com pichações e depredações ao longo do duto. 


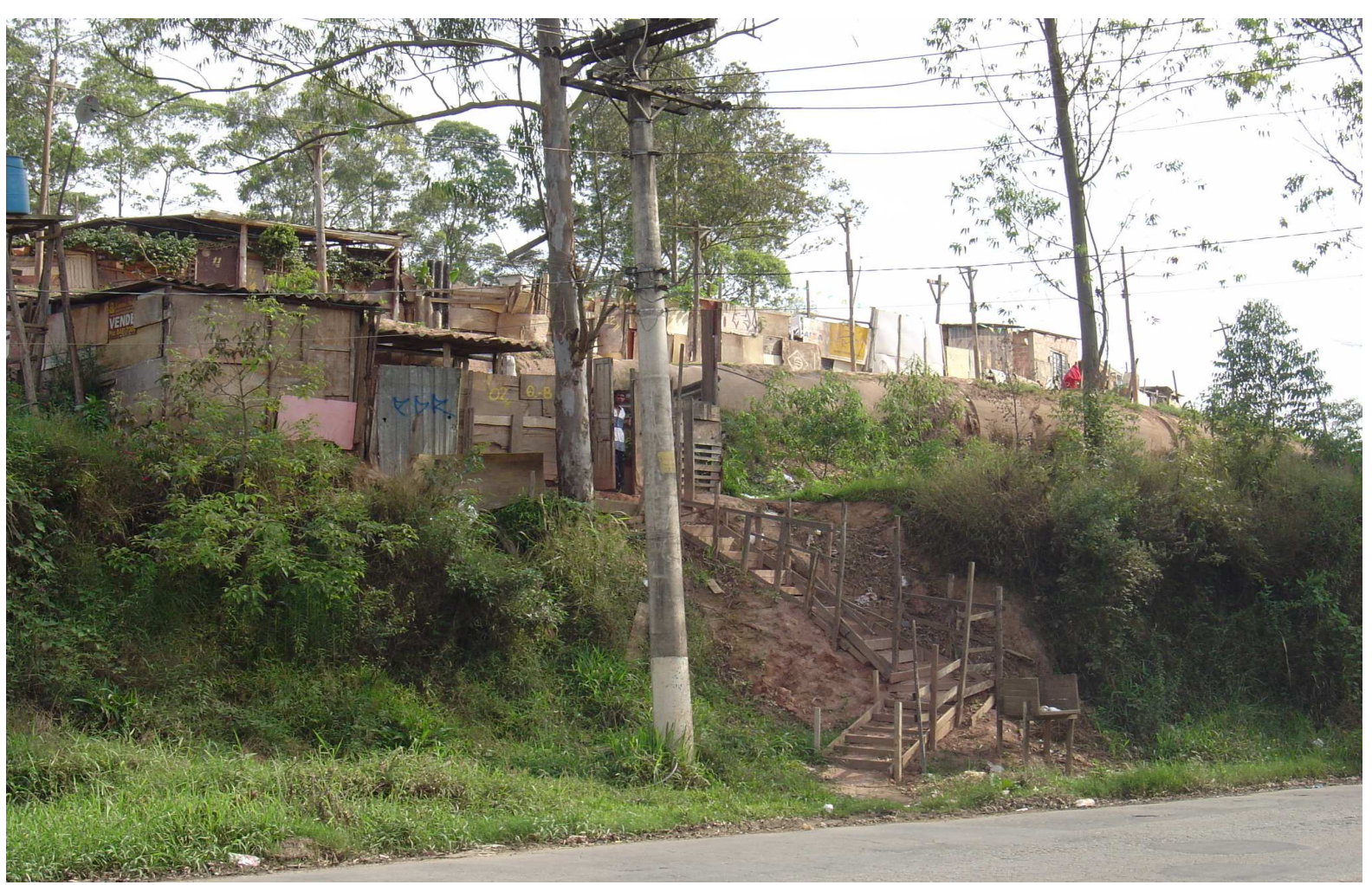

Foto da adutora em outubro de 2006.

Com a invasão da área no entorno do Cabuçu, em outro trecho da mesma estrada, a adutora serviu de alicerce para a construção de favelas.

Tentando descobrir seu curso, de quase 17 quilômetros, acompanhamos, através de ruas e praças, seus vestígios vistos à superfície, e que de repente, desaparecem tragados pelo "progresso".

Saindo do Município de Guarulhos, percorrendo-se cinco quilômetros, novamente depara-se com parte de sua estrutura, na confluência das ruas Manoel Gaya, seguindo pela rua Carlos Gentil de Laet, em São Paulo, numa elevação de $745 \mathrm{~m}$, nas coordenadas U.T.M. $337087 / 7403734$. 


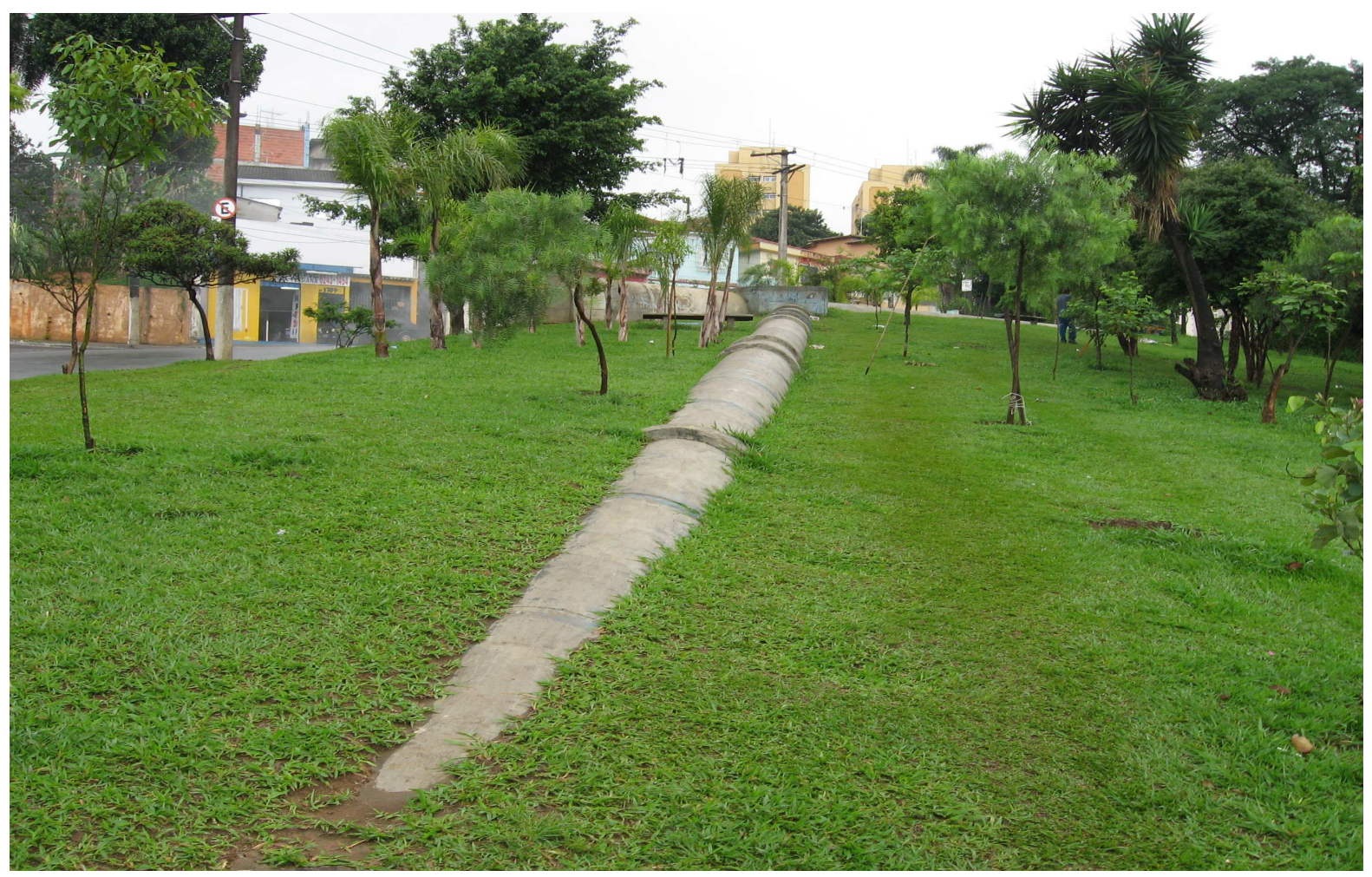

Foto de setembro de 2007, no momento em que a adutora aflora à superfície.

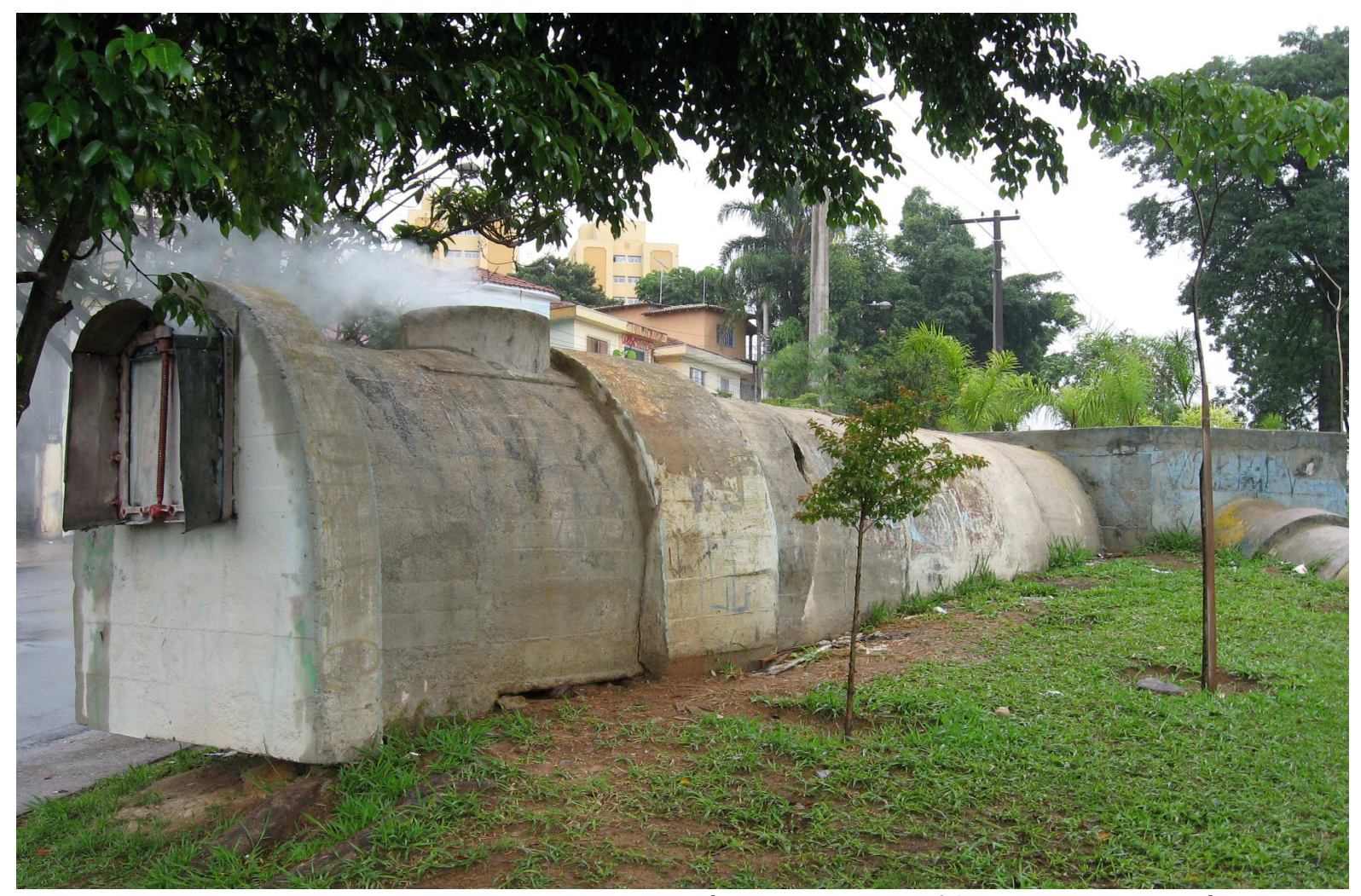

Foto de setembro de 2007, em que se vê um dos 28 sifões que constituíam o sistema de adução. 


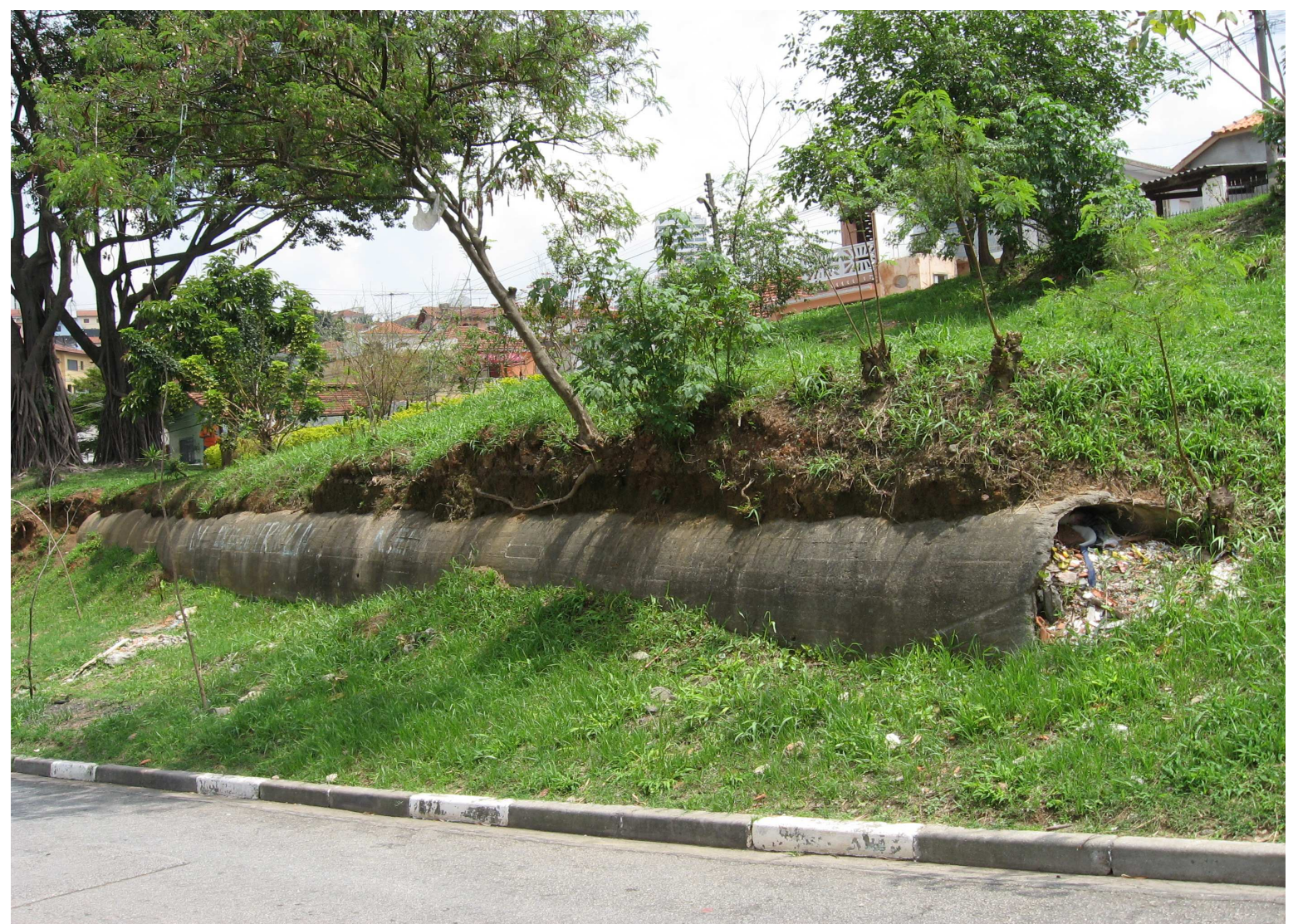

Foto da adutora, outubro de 2007

Prosseguindo, no sentido Guarulhos - São Paulo, novamente conseguimos localizar outros vestígios, na rua Professor Marcondes Domingues, bairro da Parada Inglesa, na cidade de São Paulo. Situada nas coordenadas U.T.M.7401962/0335709, numa elevação de 754 m, uma parte da adutora, está interrompida, e semi-enterrada. 


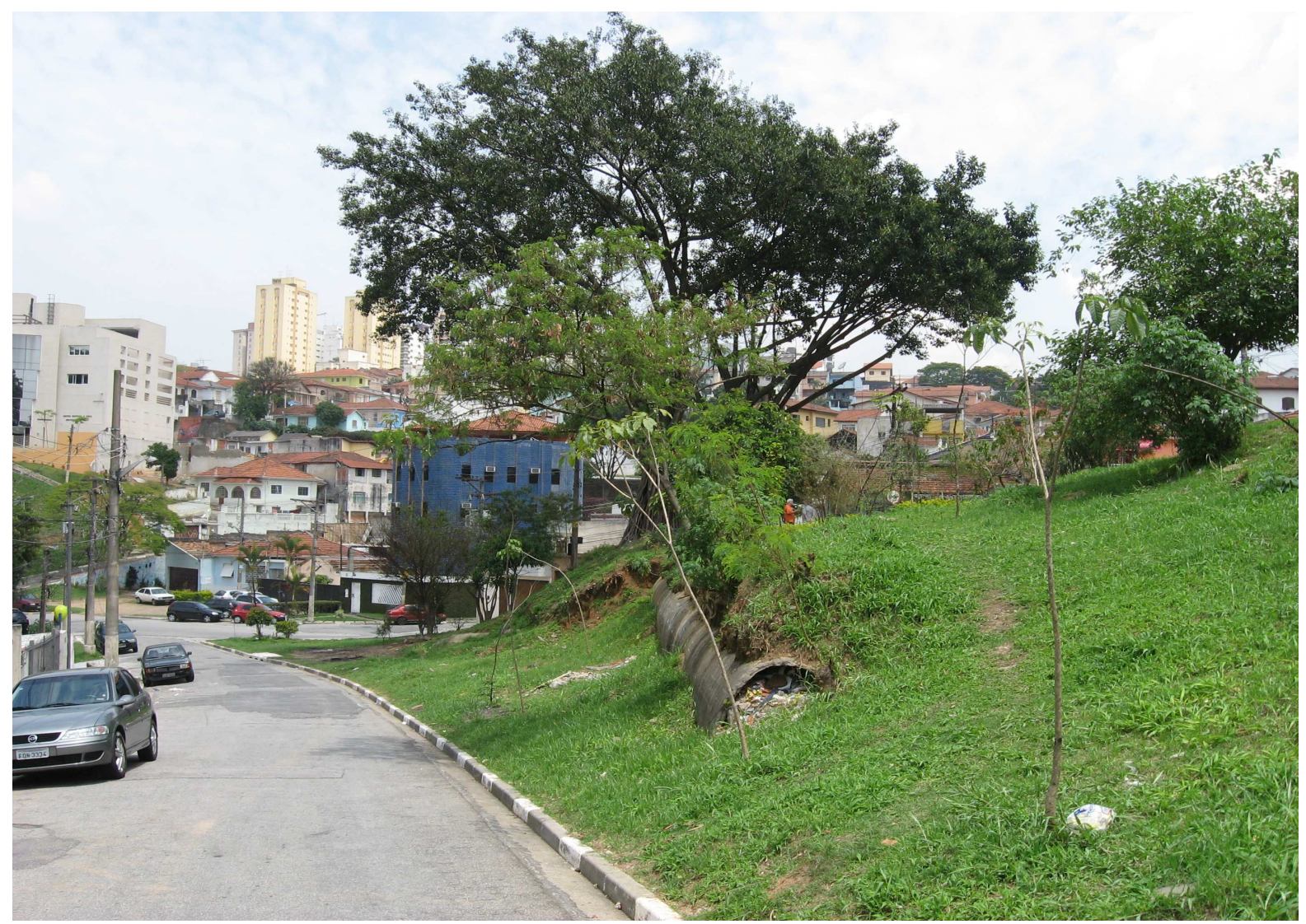

Foto da adutora, outubro de 2007

Neste ângulo, pode-se perceber a adutora atravessando uma praça, e ao fundo o crescimento desordenado de São Paulo, que provocou uma reestruturação de ruas e avenidas, da Zona Norte da cidade, feita sem o cuidado de se preservar, esse tão importante documento da história da tecnologia brasileira, que como já se disse, foi considerado por muitos, como sendo possivelmente, a obra mais importante do Brasil daquela época. 


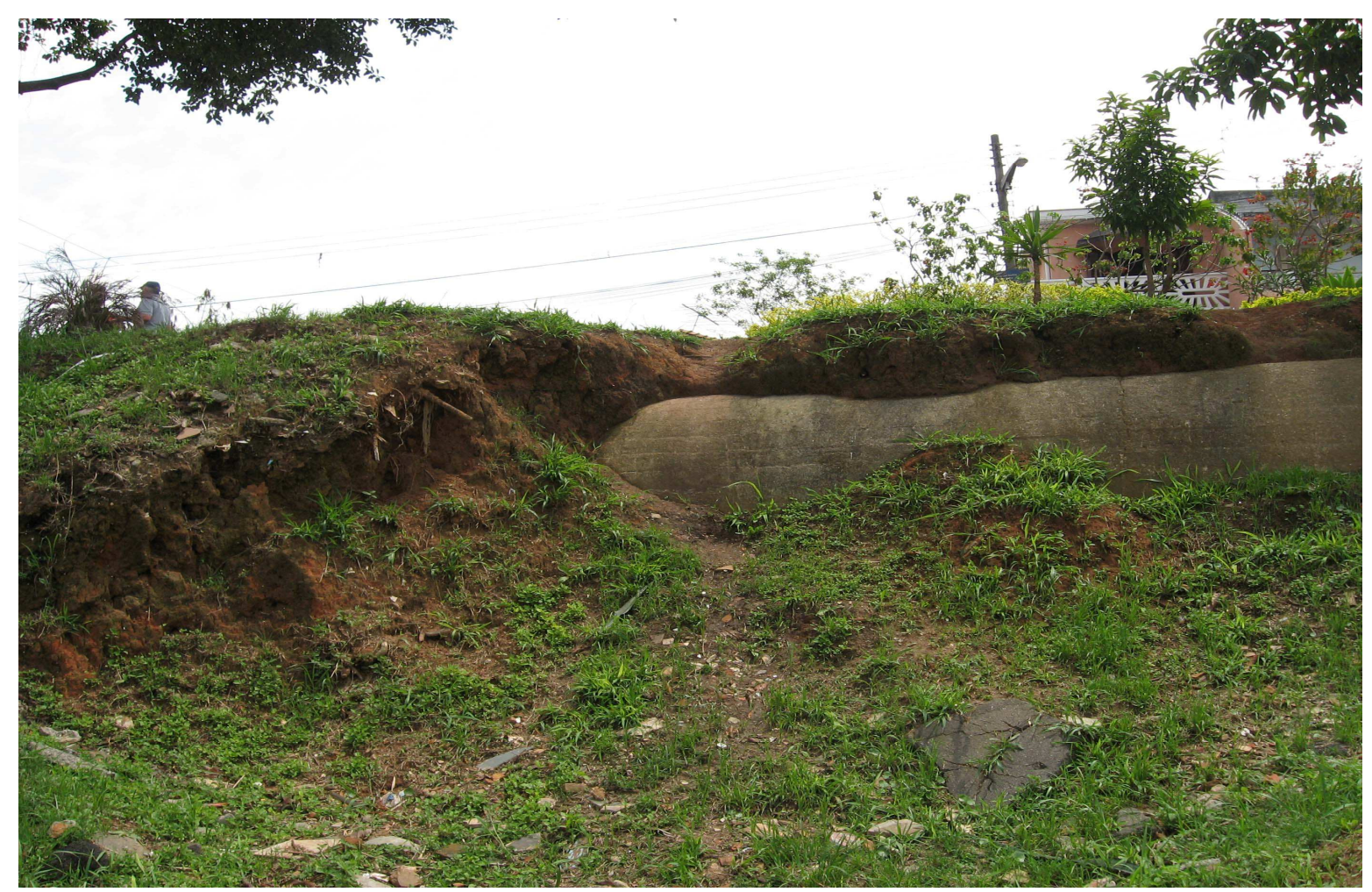

Foto da adutora, outubro de 2007.

Neste ponto, a adutora atravessa o morro de Santana, através de um túnel que originariamente era de $220 \mathrm{~m}$ de comprimento e que desapareceu, para dar lugar à nova ordenação da malha urbana, com o surgimento de bairros que destruíram parte da memória dessa centenária estrutura. 


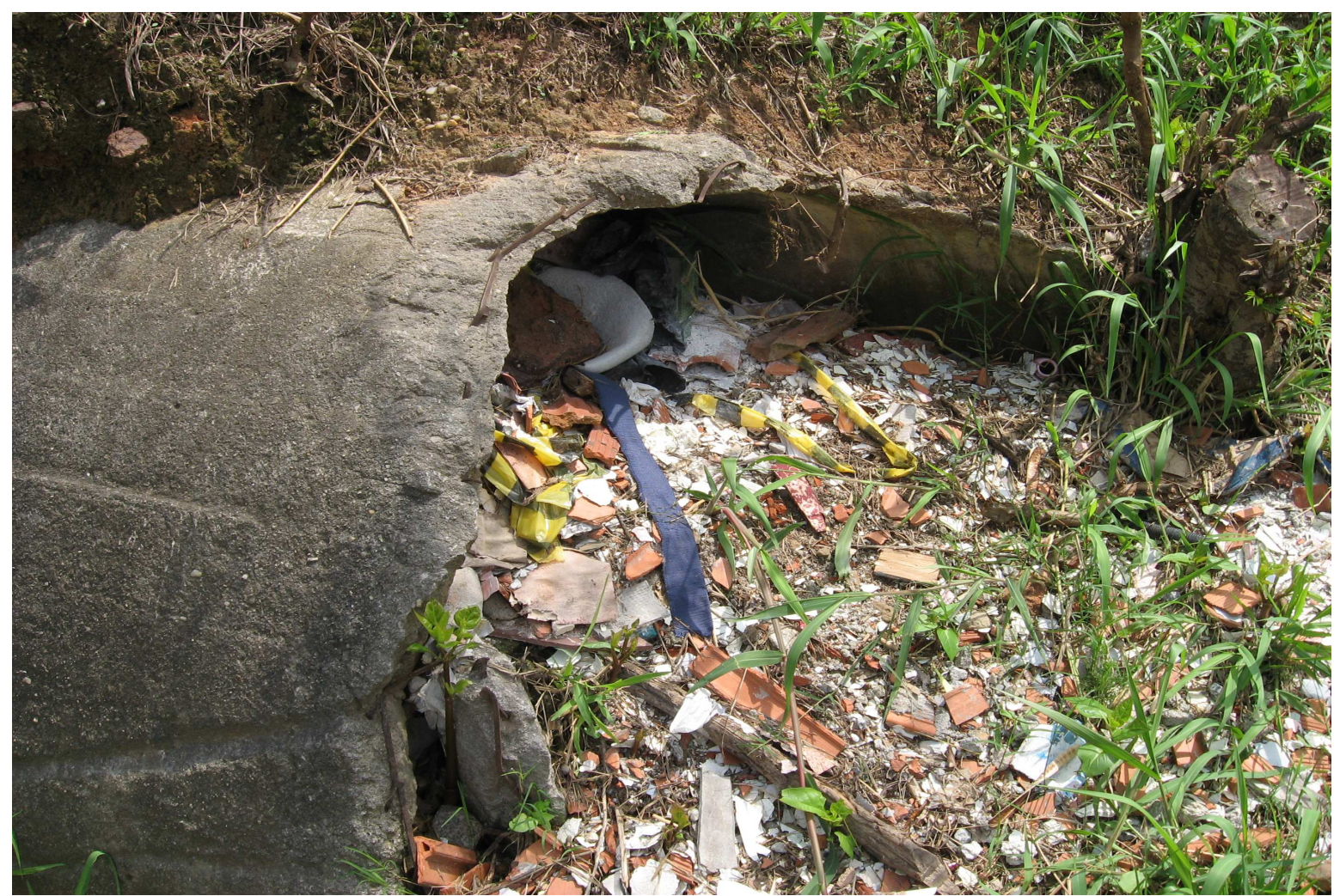

Foto da estrutura da adutora, outubro de 2007.

Embora a adutora estivesse semi enterrada, foi possível medir-se seu diâmetro interno, de 1 metro. A documentação escrita deu o suporte necessário ao trabalho de campo, uma vez que essa medida confere com a dos relatórios da Secretaria da Agricultura e da Repartição de Águas e Esgotos, da época de sua construção.

$\mathrm{O}$ aqueduto em cimento armado, tem a espessura de 90 milímetros, e as barras de ferro de suas armações, acham-se à mostra em vários pontos, como se observa nas fotos seguintes, em razão do processo de deterioração. 


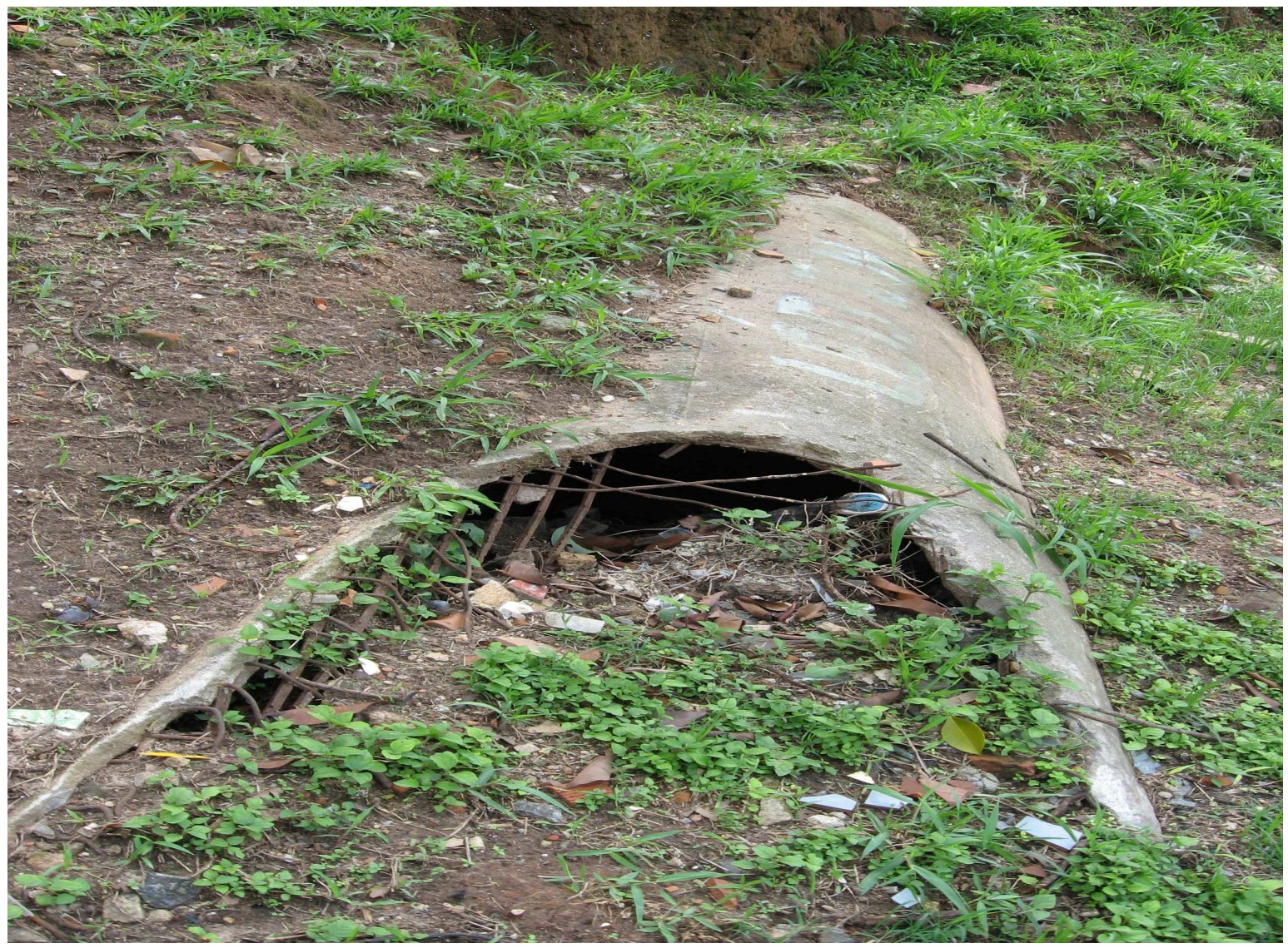

Fotos das barras de ferro do concreto armado, outubro de 2007.

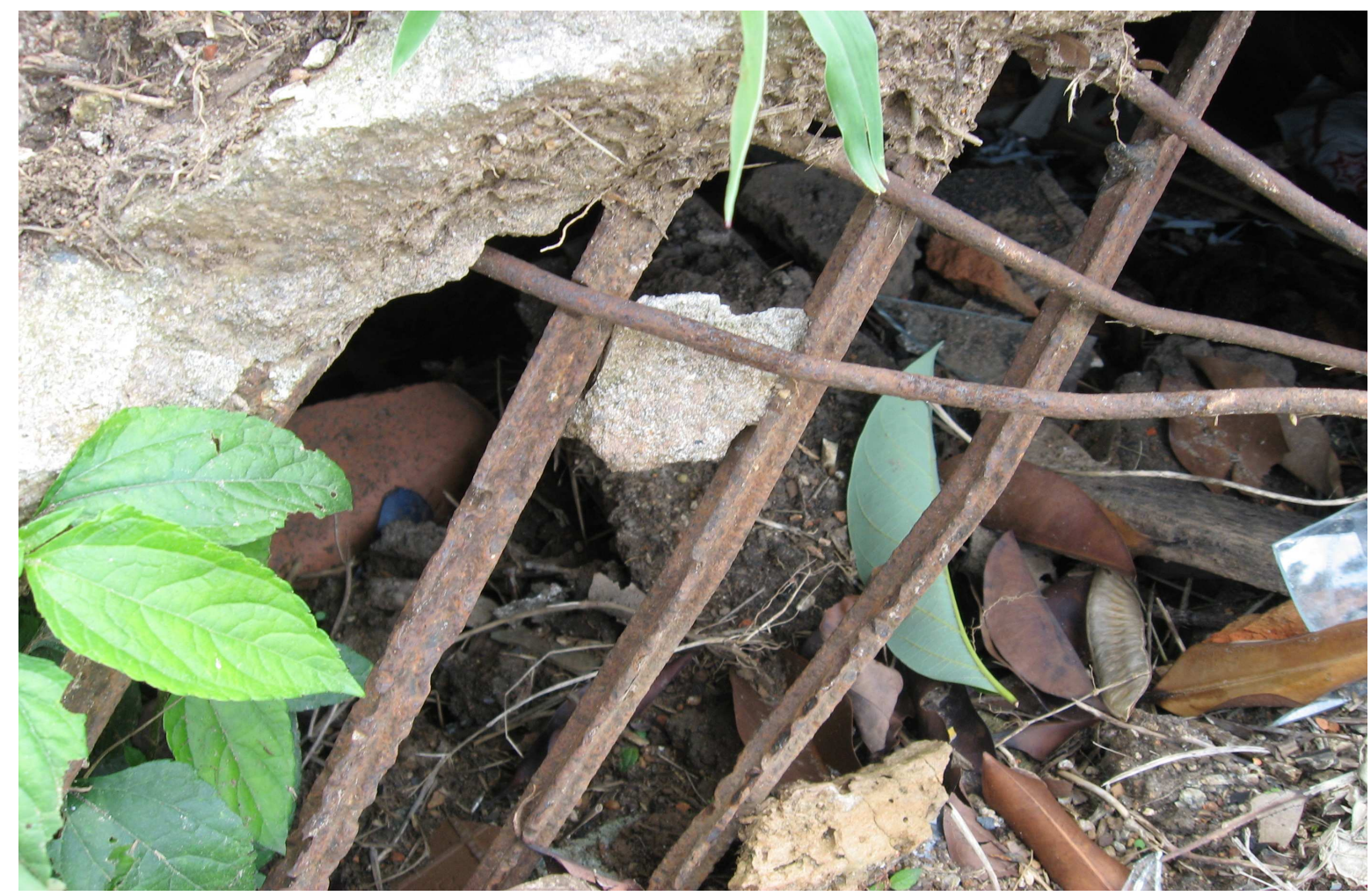

Barras de ferro 


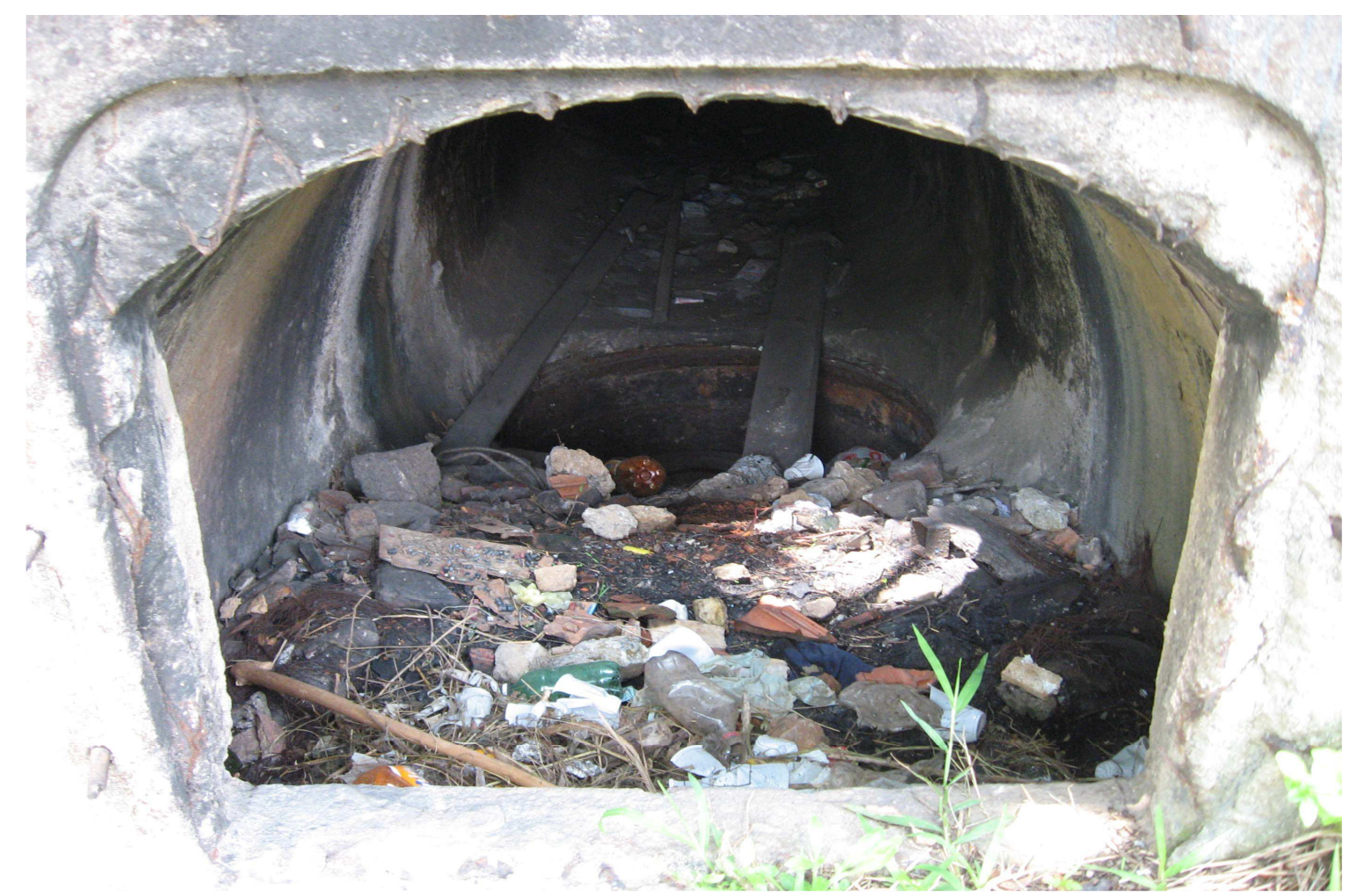

Foto de outubro de 2007, da ligação do aqueduto com o sifão.

Neste ponto, o vestígio da adutora, na confluência da Praça Mal. Eurico Gaspar Dutra com a Rua Professor Marcondes Domingues, no bairro da Parada Inglesa, em São Paulo, está numa elevação de 776m, e nas coordenadas U.T.M. 0335647/7403951. Na foto, fica perfeitamente demonstrada, a forma elíptica do aqueduto, e sua junção, com um dos 28 sifões que compunham a adução. 


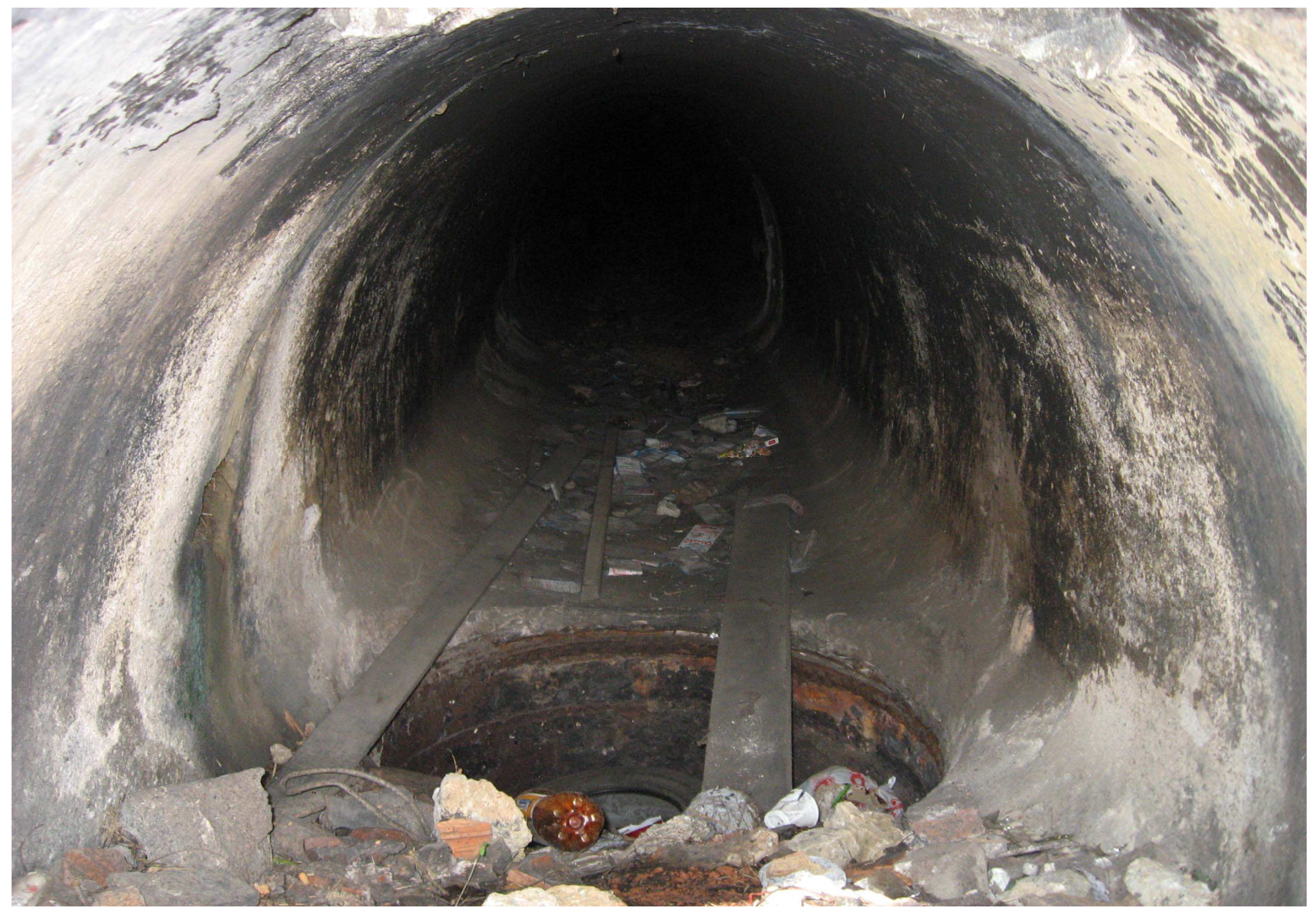

Foto de outubro de 2007, onde se vê em detalhe a ligação do aqueduto com o sifão.

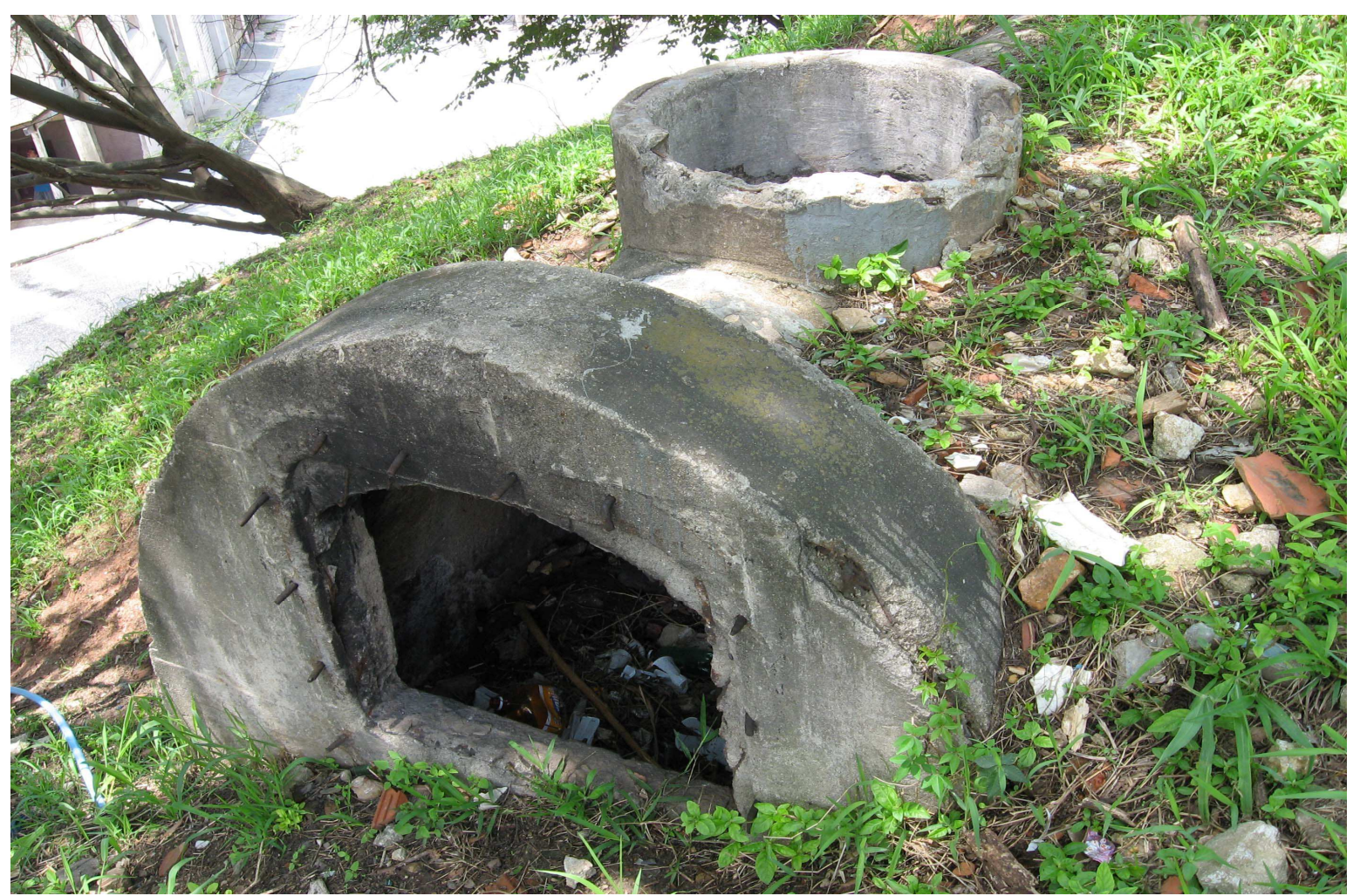

Foto de outubro de 2007, no detalhe parte do sifão. 
Cada vez mais vestígios da adutora estão desaparecendo, ao longo do tempo, e sua preservação foi relegada, uma vez que, segundo a mentalidade vigente, trata-se de um equipamento obsoleto, cuja função a que era destinada, deixou de existir.

Esta, e outras atitudes de viés econômico, como a especulação fundiária, a obtenção de altos lucros na construção, aliadas à falta de cultura, e ao fascínio do novo, contribuem para a prática sistemática da destruição do antigo, firmemente instalada em nossas concepções de se fazer cidade.

\subsection{Zonas de Distribuição do Cabuçu}

Conforme orientação determinada pelo Secretário da Agricultura, Carlos Botelho, em seu relatório de 1905, as zonas altas da cidade deveriam ser abastecidas com mananciais altos, e as zonas baixas, com mananciais baixos; portanto, com relação ao Cabuçu e ao Barrocada, a preocupação consistia não em sua captação e adução, mas sim em sua distribuição, principalmente aos bairros do Brás, Luz e Bom Retiro, podendo-se avaliar a importância do projeto que segundo LEME:

(...) que vem dar emfim satisfação ás aspirações, aliás tão justas, da parte da população mais densa, mais laboriosa, mais pobre e, por conseguinte, mais carecedora de amparo por parte dos poderes públicos. ${ }^{188}$ (LEME, 1906)

Em 1907, foi aduzida a primeira etapa do Cabuçu, para que fossem abastecidos "dois bairros distantes da cidade", Brás e Bom Retiro, um com 500 litros por segundo, e o outro com 220; para tanto, foi projetada uma canalização que ligava Santana a uma torre de distribuição, situada no jardim da Luz, cujo nível de água na cota 750, procurava abastecer, por gravidade, a zona situada na cota 735 . Essa diferença de 15 metros era necessária, para que os andares superiores das casas também pudessem ser abastecidos.

Justamente no limite dos dois bairros em questão, essa torre evitava as variações de consumo, que produziam o "coup de bélier" no sifão de um metro, e

\footnotetext{
${ }^{188}$ LEME, Luiz, Betim Paes. O Abastecimento de Agua Á Capital. In Revista Polytechnica de 1906. Typographia do "Diário Official”, São Paulo, 1906, p.182.
} 
sustentava um pequeno reservatório de cimento armado, do qual partia uma linha adutora, que acompanhava a da São Paulo Railway, atravessando o bairro do Brás, e terminando em um reservatório de compensação e acumulação, situado na Mooca.

Esta zona exigiu uma subdivisão dos setores do Bom Retiro, Brás, Mooca e Canindé, que eram alimentados por gravidade, enquanto os do Belém e Penha, exigiram instalações de recalque.

A linha adutora mista, terminava na caixa d'água em Santana, junto à rua Conselheiro Saraiva, na cota de $750 \mathrm{~m}$, de onde partia um conduto forçado, de ferro fundido, de $1.000 \mathrm{~m}$ de diâmetro com $4.000 \mathrm{~m}$ de extensão que levava essas águas até a esquina da Avenida Tiradentes com a Marquês de Três Rios. Nesse local foi construído um "stand pipe", ${ }^{189}$ onde aquele conduto se bifurcava em duas linhas de diâmetro de 0,63m, uma levada através do Bom Retiro até a esquina da alameda Nothman com a rua Comandante Salgado, onde foi colocada uma estação de recalque, para socorro do reservatório da Consolação, através da Avenida Angélica, e da rua Piauí até esse local.

A outra parte abastecia em marcha ${ }^{190}$, através das ruas São Caetano e Almeida Lima, as redes dos bairros do Canindé, Braz e Luz, até o reservatório de sobras da rua Taquari, com capacidade de $5.000 \mathrm{~m}^{3}$ e na altitude de $746 \mathrm{~m}$.

No relatório de 1909, dirigido ao Secretário da agricultura pelo Diretor da R.A.E., estavam descritas as ruas do bairro do Brás que eram abastecidas por gravidade pela distribuição do Cabuçu: “ (...) abrange a linha poligonal definida pelas ruas de Santa Clara, João Boemer, José Monteiro, 21 de Abril, Bairão, Saude e Bresser. Quando porém a Repartição dispuzer do material necessário,

\footnotetext{
${ }^{189}$ Stand-pipes, também chamados de chaminés de equilíbrio, são estruturas intercaladas geralmente no trecho de transmissão entre uma adutora de recalque e uma de gravidade. Tanto a entrada como a saída, ficam na parte inferior, podendo o nível de água oscilar no interior da estrutura com flutuações nas vazões de bombeamento ou de escoamento no trecho de gravidade. São estruturas destinadas a suportar trechos de tubulações que, por razões de segurança ou outros motivos, não devem se apoiadas diretamente no terreno.

OLIVEIRA, Walter Engrácia de, et alli. Técnica de Aabastecimento e Tratamento de Água.Vol I. Abastecimento de Água. Editora da Companhia Estadual de Tecnologia de Saneamento Básico e de Defesa do Meio Ambiente (CETESB), São Paulo, 1976, p.388.

190"Os condutos d'água na maioria tem uma vazão constante, isto é, a de juzante igual a de montante. Porém existem muitos condutos que fazem o abastecimento ao longo de seu percurso, em numerosos pontos de tomada e derivação. Nessas condições a vazão de juzante será menor do que a de montante, dizendo-se que a canalização tem um "serviço em trânsito", ou faz a "distribuição em marcha". In AZEVEDO, NETTO, José Manoel. Manual de Hidráulica.Edgard Blücher Ed. São Paulo,1957.P.21.
} 
(...)pretendemos estabalecer a peripheria da rêde do lado horiental, com a inclusão das ruas Joaquim Carlos, Firmino Pinto e continuando pelas vias publicas citadas......" 191

Uma parte do bairro ficava isolada da zona baixa, e compreendia a Avenida da Intendência, atual Celso Garcia, Felipe Camarão, Serra da Bocaina, Cambaropy, linha da Estrada de Ferro Central do Brasil, a parte oriental das ruas Bairão, Firmino Pinto e Joaquim Carlos, ameaçadas de serem abastecidas quase in natura, pelas águas do Tietê, cujas análises químicas e bacteriológicas realizadas durante três anos consecutivos, acusavam-nas ora de impotáveis, ora de suspeitas, muitas vezes medíocres, necessitando de tratamentos longos e eficazes, dispendiosos para os cofres públicos, segundo os relatórios da época.

$\mathrm{Na}$ tentativa de solucionar essa questão, e aproveitarem as sobras do Cabuçu, elevaram suas águas ao recém construído reservatório do Belenzinho, através de uma bomba turbina, conjugada a um motor elétrico de $45 \mathrm{cv}$, instalado em um chalé, construído em terreno adquirido para o reservatório da Mooca.

De acordo com esse plano, ficaram as águas da Cantareira destinadas apenas ao suprimento das zonas, média (reservatório da Consolação) e da alta, (reservatório da Avenida), evitando-se que fosse derivado destes, o volume que devia suprir as zonas baixas, antes dessas obras.

As pressões de distribuição destas águas, variando entre 5 e 10 metros de coluna d'água, suficientes na época da construção da adutora, foram pouco a pouco se tornando precárias, à medida que o bairro do Braz foi se desenvolvendo, e por via de conseqüência, a ampliação de sua rede distribuidora ocasionou uma perda de carga considerável, diminuindo as pressões da distribuição.

Como não existissem zonas, em que as águas do Cabuçu pudessem ser aduzidas por gravidade, para a distribuição com pressões disponíveis, foi feito um estudo para o abastecimento do Alto de Santana, sem tratamento químico, aprovado pelas vantagens então apresentadas, principalmente no que dizia respeito à proximidade dessas águas com a área a ser abastecida. .

Ao ser inaugurada, solenemente, a $1^{\circ}$ de Setembro de 1907, por Carlos Botelho, Secretário da Agricultura, a linha adutora do Cabuçu, pela qual fluíam 400 litros de água por segundo, representou um reforço que melhorou a taxa de

\footnotetext{
${ }^{191}$ Relatório da repartição de Águas e Esgotos de São Paulo, de 1909, enviado ao Secretário de Agricultura pelo Diretor. Editora Casa Garraux, São Paulo, 1910, p.45.
} 
distribuição per capita, julgando-se a população, por alguns poucos anos, bem abastecida. Essas águas foram, nesse mesmo dia, distribuídas somente ao bairro do Braz. Tinham sido concluídas, na mesma ocasião, as obras referentes à pequena barragem, arejador, trechos de aquedutos e sifões de cimento armado, o sifão metálico, a torre, as principais linhas de distribuição, e a parte interna do reservatório da Mooca.

Quando a Comissão de Obras Novas, aproveitou o reibeirão do Cabuçu para alimentar a zona baixa da cidade, teve o intuito de captar também as águas do Barrocada, razão pela qual construiu a linha adutora, com capacidade suficiente para transportar os dois volumes reunidos, a partir de um ponto que seria escolhido para a junção dos respectivos aquedutos. À montante desse ponto, uma seção da linha adutora foi reduzida, para comportar somente o volume do Cabuçu, e a jusante, ampliada, para receber as águas do Barrocada que eram avaliadas em 100 litros por segundo, ou 8.640 .000 em 24 horas. ${ }^{192}$

${ }^{192192}$ ARTHUR, Motta. Estudos Preliminares para o Reforço do Abastecimento D'Agua da Cidade de São Paulo. Typographia Brazil - Rothschild \& Co., São Paulo, 1911.pp 104 a 106. 


\subsection{Represa do Barrocada}

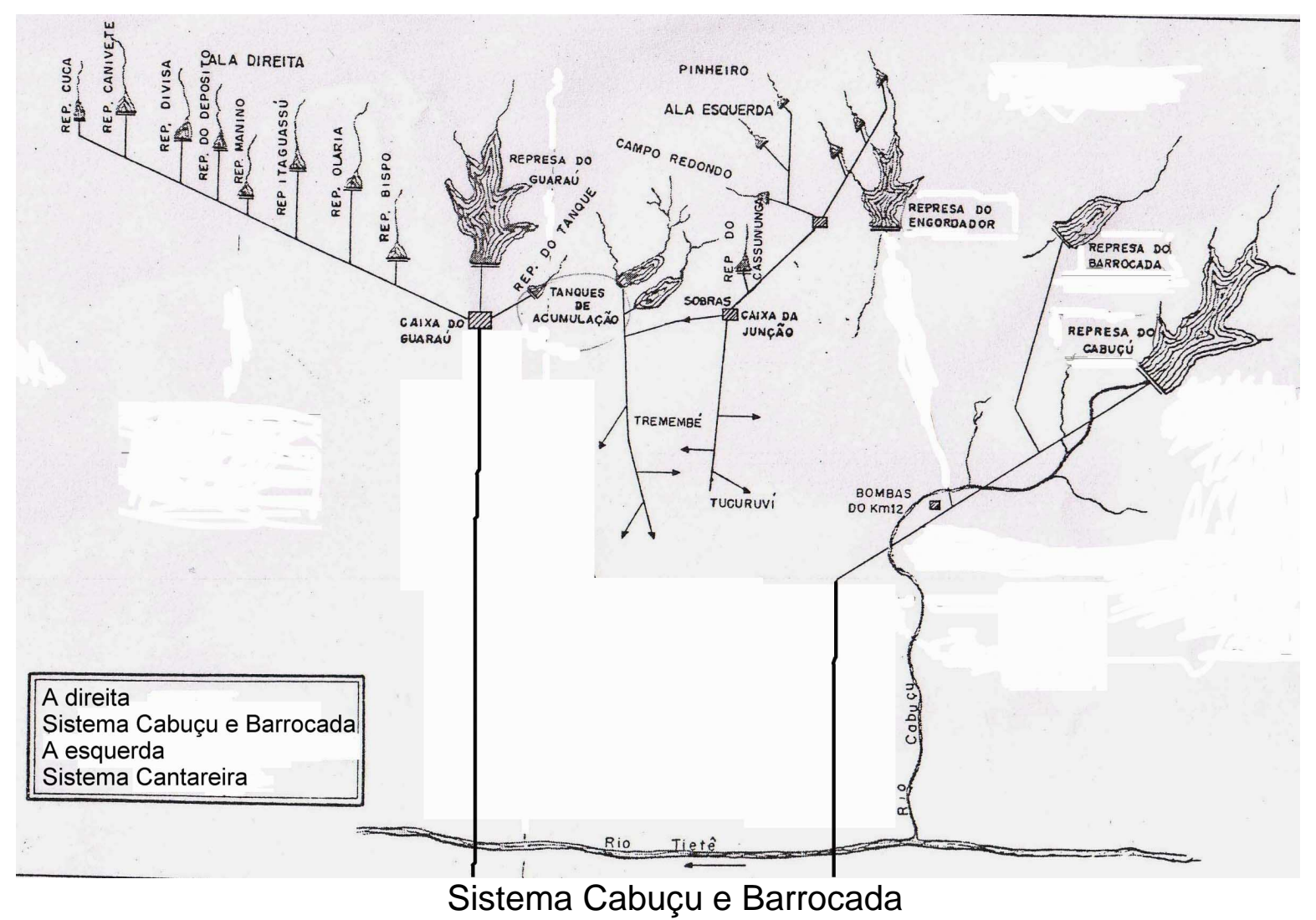

Segundo os relatórios da R.A.E., o Governo julgou que deveria postergar o aproveitamento do Barrocada, não apenas como medida de economia, como também para evitar que houvesse desperdício, julgando que naquele momento, (1907), não era tão necessário esse volume suplementar. Assim, a partir do quilometro 14, ficou o aqueduto do Cabuçu, com a seção da vazão suficiente para receber lateralmente as águas do Barrocada, cujo projeto de adução estava sendo preparado.

Passado pouco tempo após a inauguração do novo abastecimento, foi notada escassez de água na zona baixa, que pouco se beneficiou com o novo plano posto em prática, não só devido ao extraordinário crescimento dessa parte da cidade, com o aumento do número de prédios ligados à rede, como também porque parte desse volume foi elevado para socorrer as zonas média e alta.

Em 1911, novamente uma grave estiagem assolou São Paulo de Julho a Dezembro, tendo havido por várias vezes enfraquecimento na distribuição do líquido, ao andar inferior da cidade, levando as autoridades a suspender o 
funcionamento de uma bomba elevatória, colocada na rua das Palmeiras, a fim de socorrer o reservatório de compensação da Mooca, que vazio, diminuia a carga piezométrica da rede distribuidora.

Dizia Arthur Motta, "a única contribuição aproveitada actualmente é a do ribeirão do Cabuçu, porque não foi até hoje (1911), captado o Barrocada e está isolado do abastecimento o lago formado pela barragem do Cabuçu". ${ }^{193}$

Diante da emergência, e dos serviços já executados, foram feitos os levantamentos topográficos priliminares, a medição na época de estiagem das águas do ribeirão, e dos os mananciais de seu entorno, indispensáveis para completar o programa elaborado por Carlos Botelho, Secretário da Agricutura, quando era Presidente do Estado Jorge Tibiriçá.

De acordo com a diretriz do projeto, o traçado da linha adutora do Barrocada era de $5.756 \mathrm{~m}$, assim discriminados: $4.015 \mathrm{~m}$ de aqueduto de cimento armado, de seção circular, com 0,05 m de espessura, 0,46 m de diâmetro; 1.741 $\mathrm{m}$ de condutos forçados, constituídos por tubos de ferro fundido, de 0,63 $\mathrm{m}$ de diâmetro e que foram aproveitados por estar o material nos depósitos da R.A.E., desde 1896.

A descarga da linha adutora foi fixada em 15.000.000 de litros/dia, para contribuir no abastecimento de água, com as sobras do Engordador, Currupira e Campo redondo, em épocas de estiagem normal, porém, a descarga mínima medida em 28 de dezembro de 1911, foi de 88 litros por segundo, ou 7.603.200 em 24 horas, em razão da forte seca que a Capital tinha sofrido nesse ano.

A R.A.E., argumentando sobre o exagero da capacidade da linha adutora, justificava-se por dois motivos: a existência de um plano da repartição, que já havia sido aprovado pelo Secretário da Agricultura, de captar as águas do ribierão Cotia para alimentar os andares superiores da cidade, dispensando desta maneira, a bomba do Engordador, que consumia dos cofres públicos grandes despesas para seu custeio; em segundo lugar, a necessidade de se aduzir o manancial do ribeirão do Currupira, e finalmente colocar no abastecimento, as águas do lago artificial do Engordador, em cuja barragem o Estado havia despendido uma soma avultada para a época.

\footnotetext{
${ }^{193}$ MOTTA, A. Estudos Preliminares para o Reforço do Abastecimento D’Água da Cidade de São Paulo. Editora Typographia Brazil - Rothschild \& Co., São Paulo, 1911, p.12.
} 
Sendo o Barrocada um manancial, a idéia de seu aproveitamento para abastecer por gravidade a zona baixa, exigiu das autoridades que fossem declarados de utilidade pública, e consequentemente desapropriados, os terrenos situados na bacia do ribeirão do Cabuçu e do Engordador, que passaram então a pertencenter ao Estado.

Em 1912, a Repartição de Águas e Esgotos terminou a execução da segunda etapa, canalizando para a adutora os recursos do vale do Barrocada, construindo a represa, e o clarificador, o que representou uma contribuição importante na tentativa de solucionar o grave problema de abastecimento de água, que se constituía em questão de calamidade pública, em uma cidade cujo adensamento populacional ultrapassava as expectativas mais otimistas. $O$ volume de água disponível, passou a ser de 58.000.000, com a adução dos 8.000 .000 de litros do Barrocada; estimavase, porém, que a necessidade de litros/dia da cidade era de 96.000 .000 havendo, portanto, um déficit que girava em torno de 38.000 .000 de litros diários. 


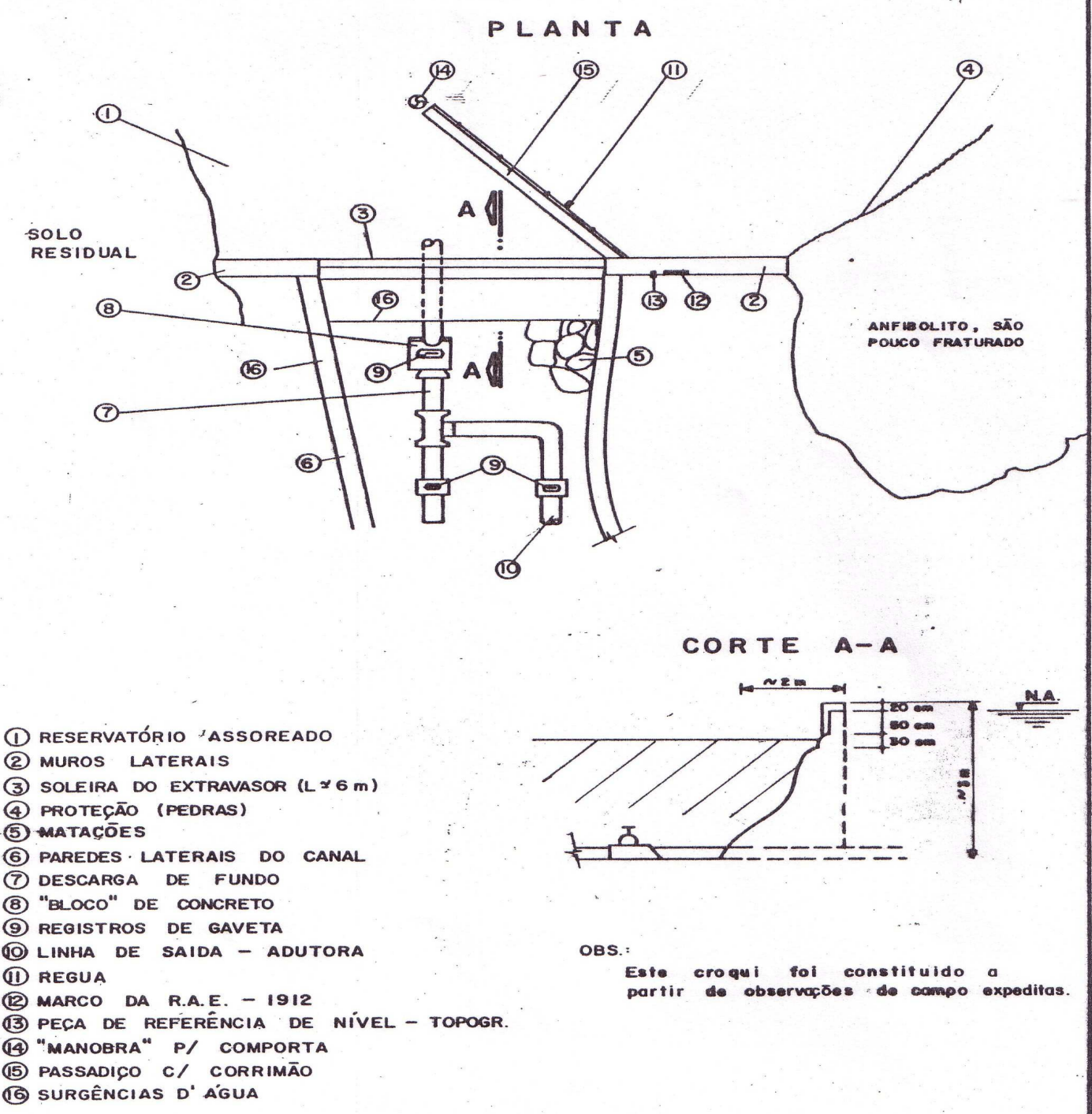

(1) RESERVATÓRIO ASSOREADO

(2) MUROS LATERAIS

(3) SOLEIRA DO EXTRAVASOR ( $\angle \propto 6 \mathrm{~m})$

(9) REgISTROS DE GAVETA

(13) PECA DE REFERÉNCIA DE NIVEL - TOPOGR.

(16) SURGÊNCIAS D' A'GUA

\begin{tabular}{|c|c|c|c|c|c|}
\hline \multicolumn{6}{|c|}{ Cia de Saneamento Básıco do Estado de Säo Paulo-SABESP } \\
\hline \multicolumn{6}{|c|}{ CROQU1 - BARRAGEM DO BARROCADA } \\
\hline \multicolumn{6}{|c|}{ Instituto de Pesquisas Teqnológicos do Est. de São Paulo.S/A-I.RT. } \\
\hline fyara & Tulwo & 713 & $10 / 12 / 81$ & R. $15.615-\mathrm{V} .3$ & 01 \\
\hline DESENHO & RESP TÉC. & APROVADO & OATA & RELATÓRIO & DES. \\
\hline
\end{tabular}

Croqui da Barragem do Barrocada feito pelo Instituto de Pesquisa Tecnológica (IPT) 


\subsubsection{Trabalho de Campo}

O ribeirão do Barrocada, compreendido na área da reserva do Parque Estadual da Cantareira, encontra-se localizado entre as serras: Cantareira e Pirucaia.

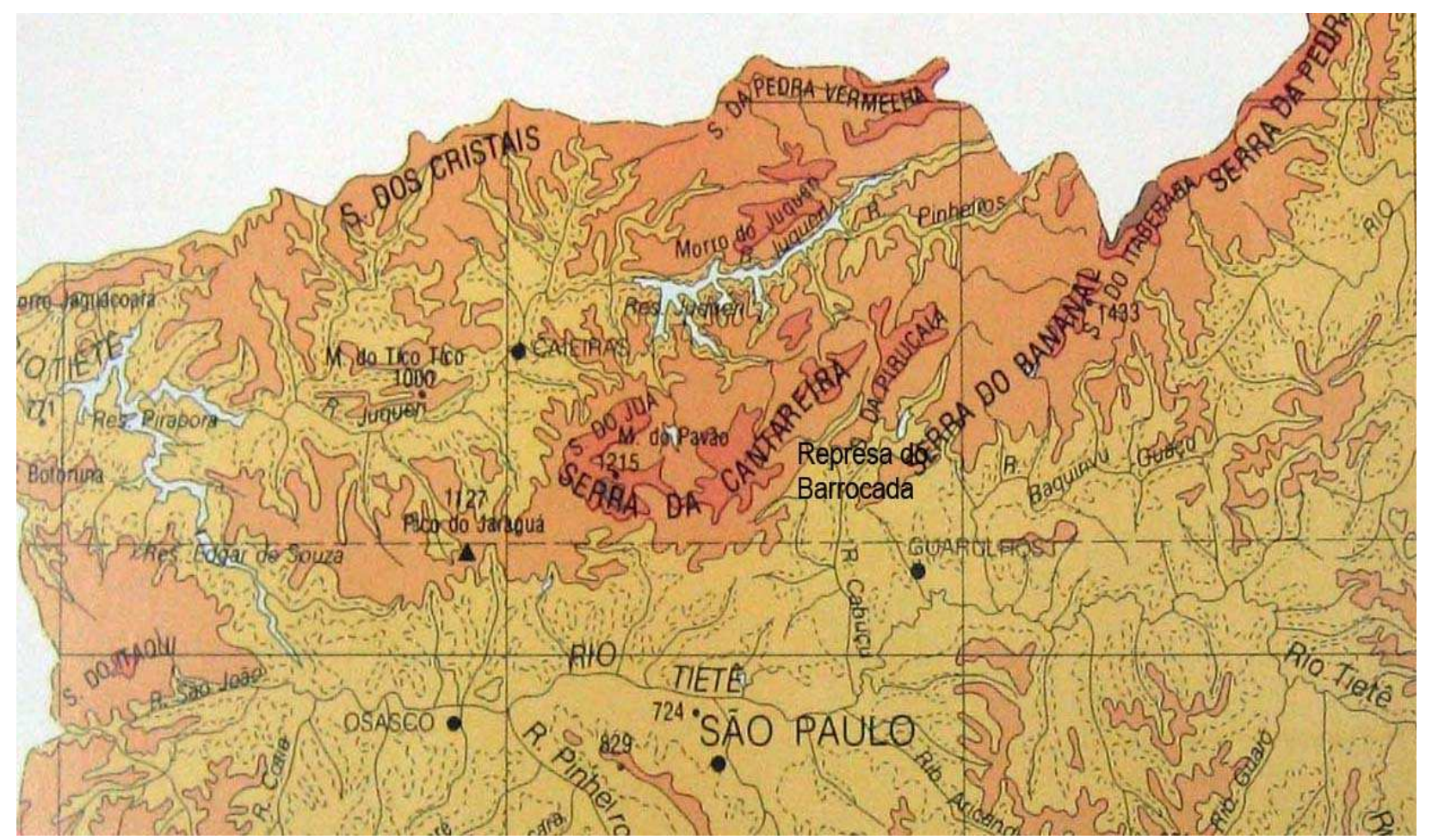

Mapa de hidrografia e relevo.Carta planialtimétrica em curvas de nível Escala 1:100 000.

No detalhe do mapa, a Represa do Barrocada. Secretaria de Economia e Planejamento do Estado de São Paulo. 


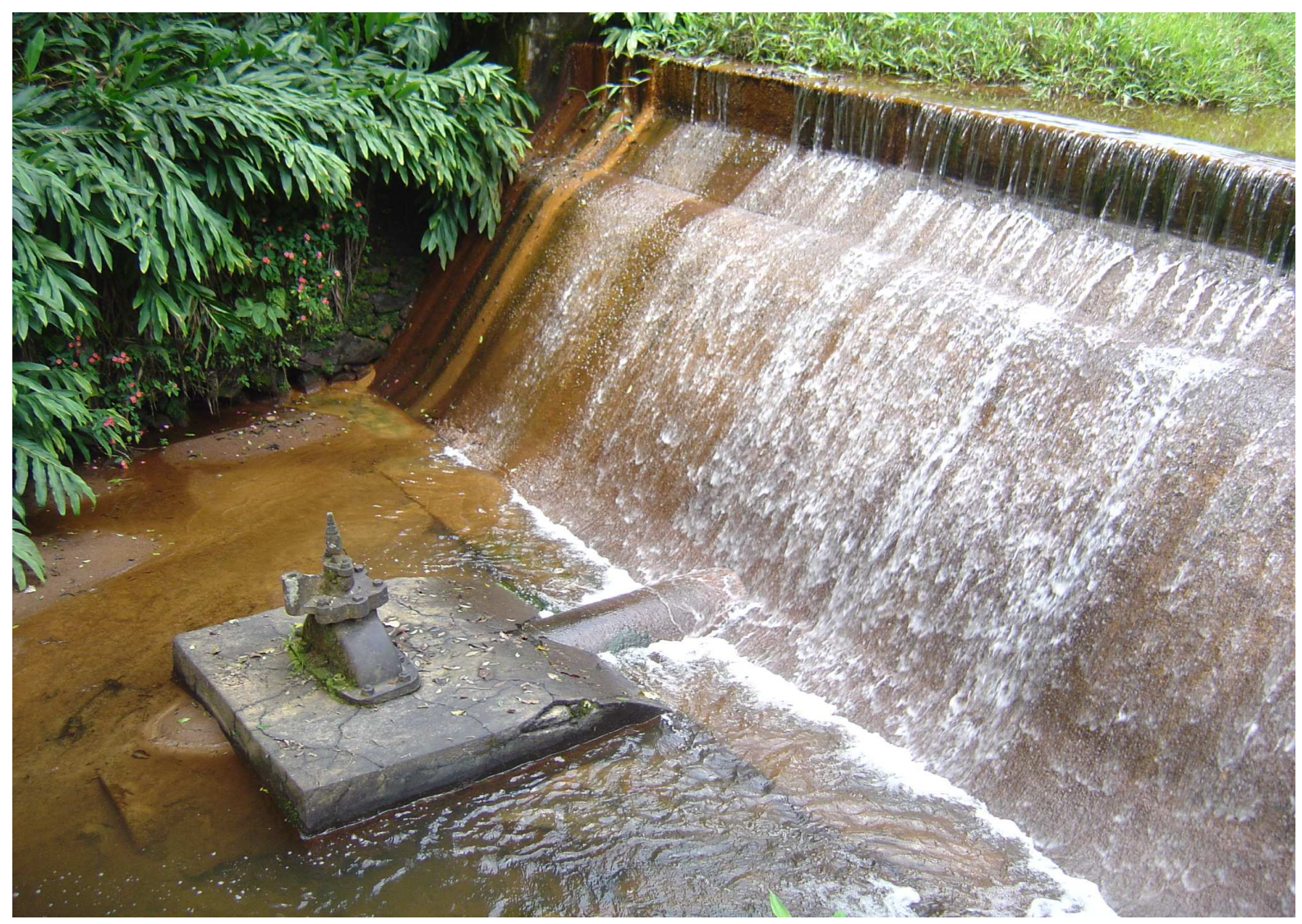

Foto de outubro de 2006, do vertedor da represa do Barrocada.

$\mathrm{Na}$ foto, a fundação da barragem em um bloco de concreto, e a soleira do vertedor, com seis metros de comprimento, dois de largura e três de altura. No detalhe, registro de gaveta desativado e obstruído, uma vez que não existe mais a descarga de fundo como se vê nitidamente. 


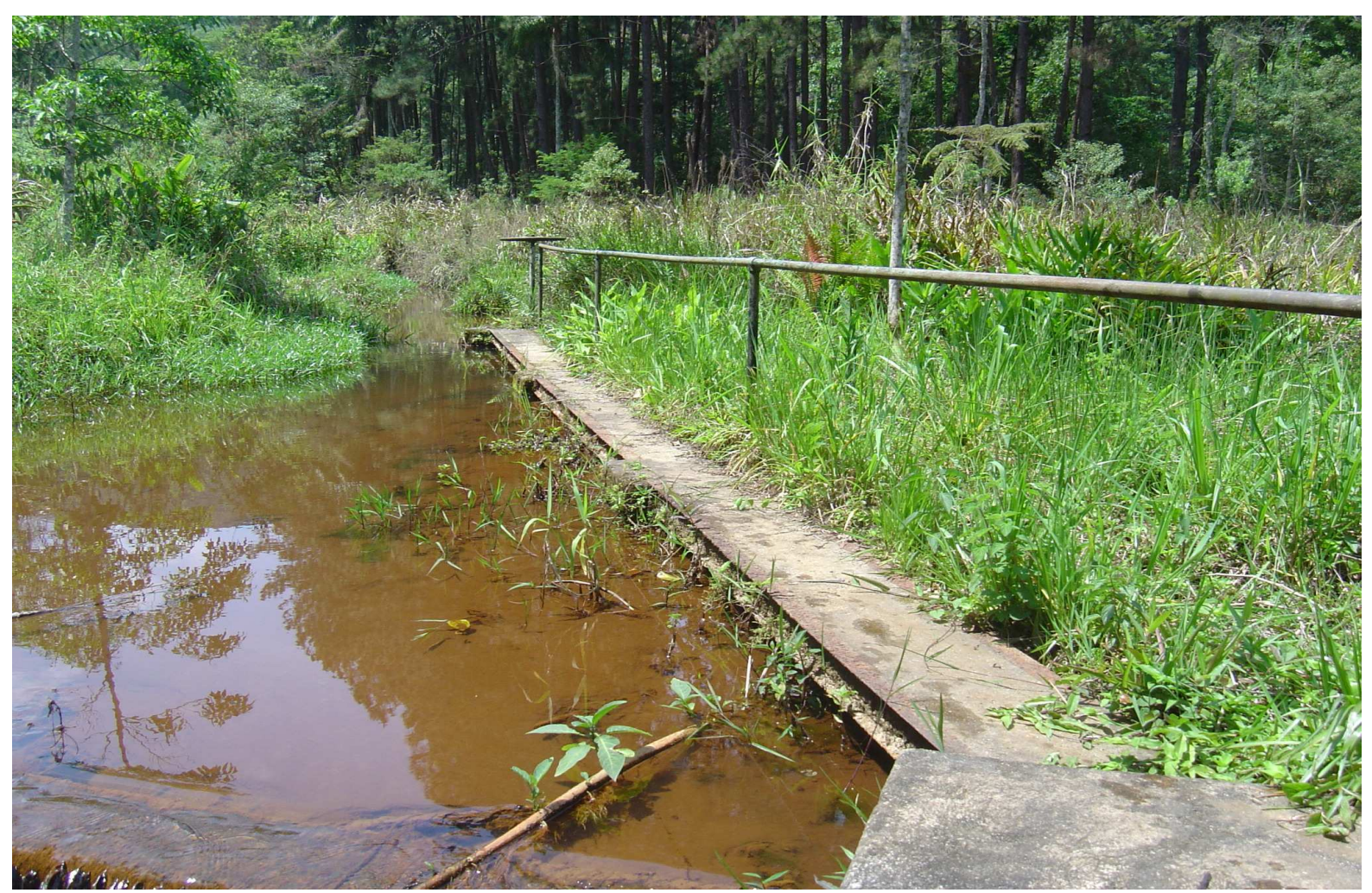

Foto de outubro de 2006.

$\mathrm{Na}$ foto o passadiço com um corrimão de apoio, que leva ao registro de manobra da comporta (fundo da foto).

Como pode se observar o reservatório encontra-se assoreado, quase que completamente coberto pela vegetação, o único sinal evidente de sua existência, é justamente o vertedouro com muros laterais. 


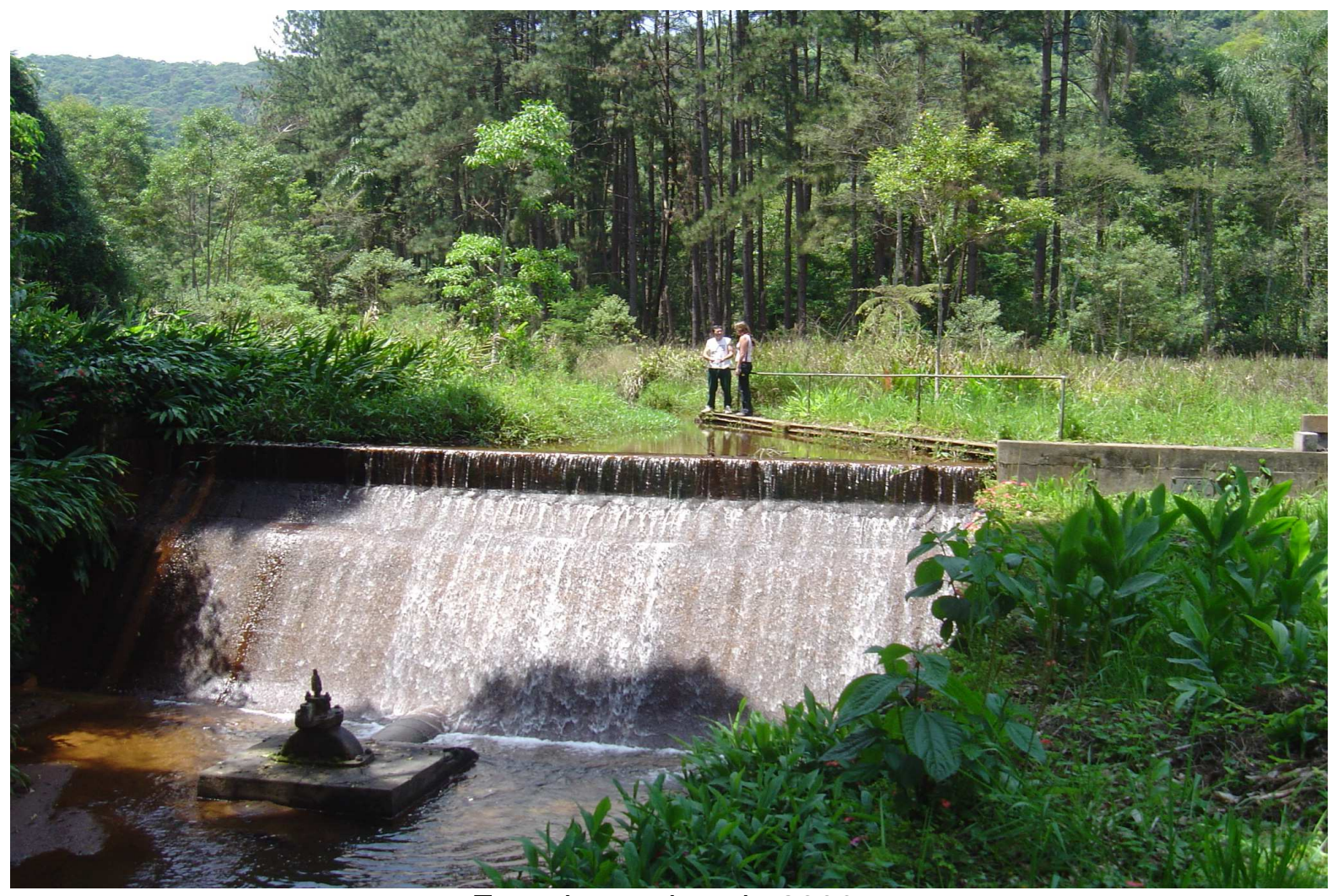

Foto de outubro de 2006.

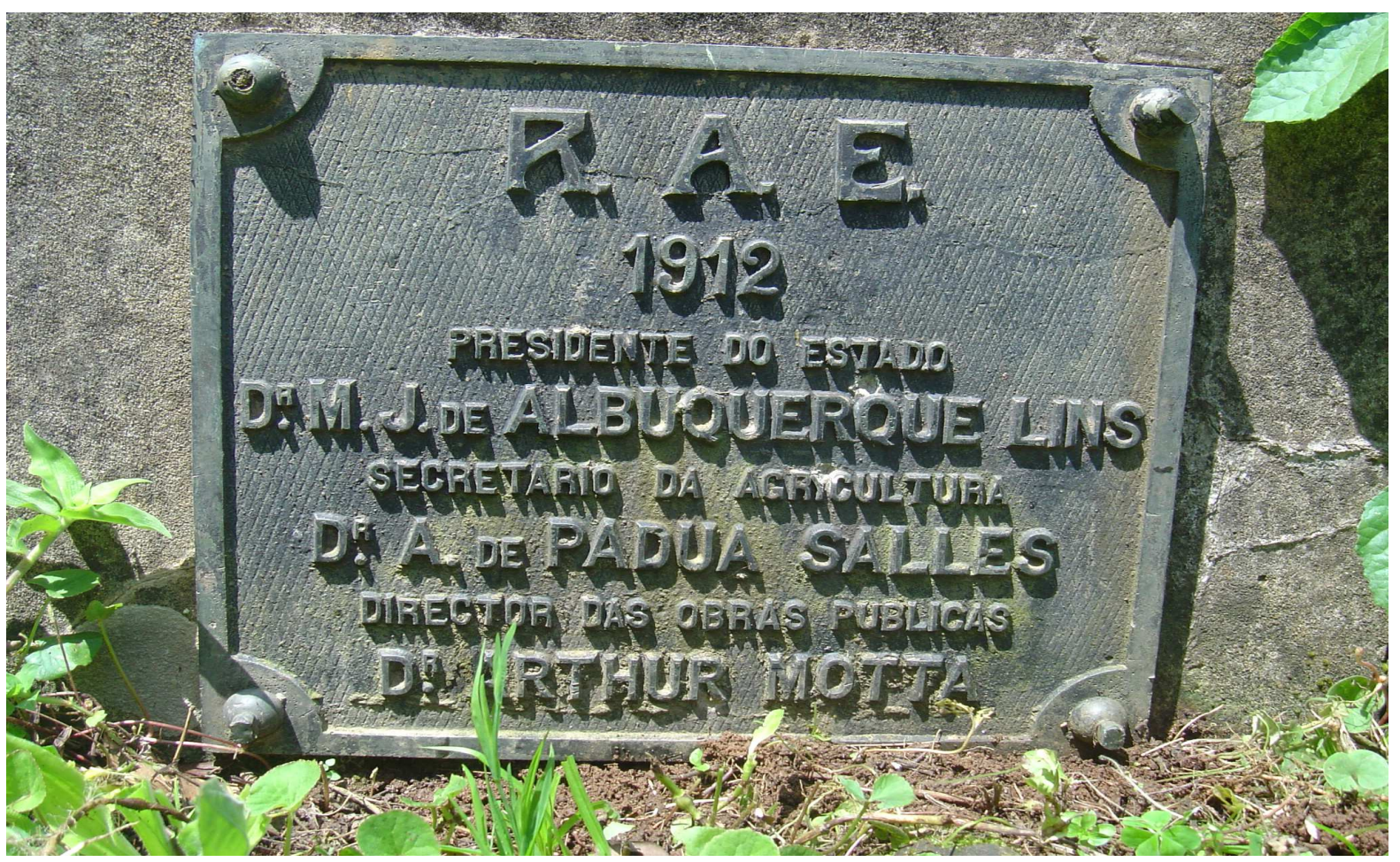

Foto de outubro de 2006, placa de inauguração da adução do Barrocada feita pela R.A.E. em 1912. 
Nas pesquisas de campo sobre o abastecimento de água, na Serra da Cantareira, nunca foram encontradas placas, em perfeito estado de conservação, como é o caso desta, afixada junto à mureta de proteção do vertedouro. Era comum a R.A.E., colocá-las com a data da inauguração de seus trabalhos. Todas foram retiradas ao longo do tempo.

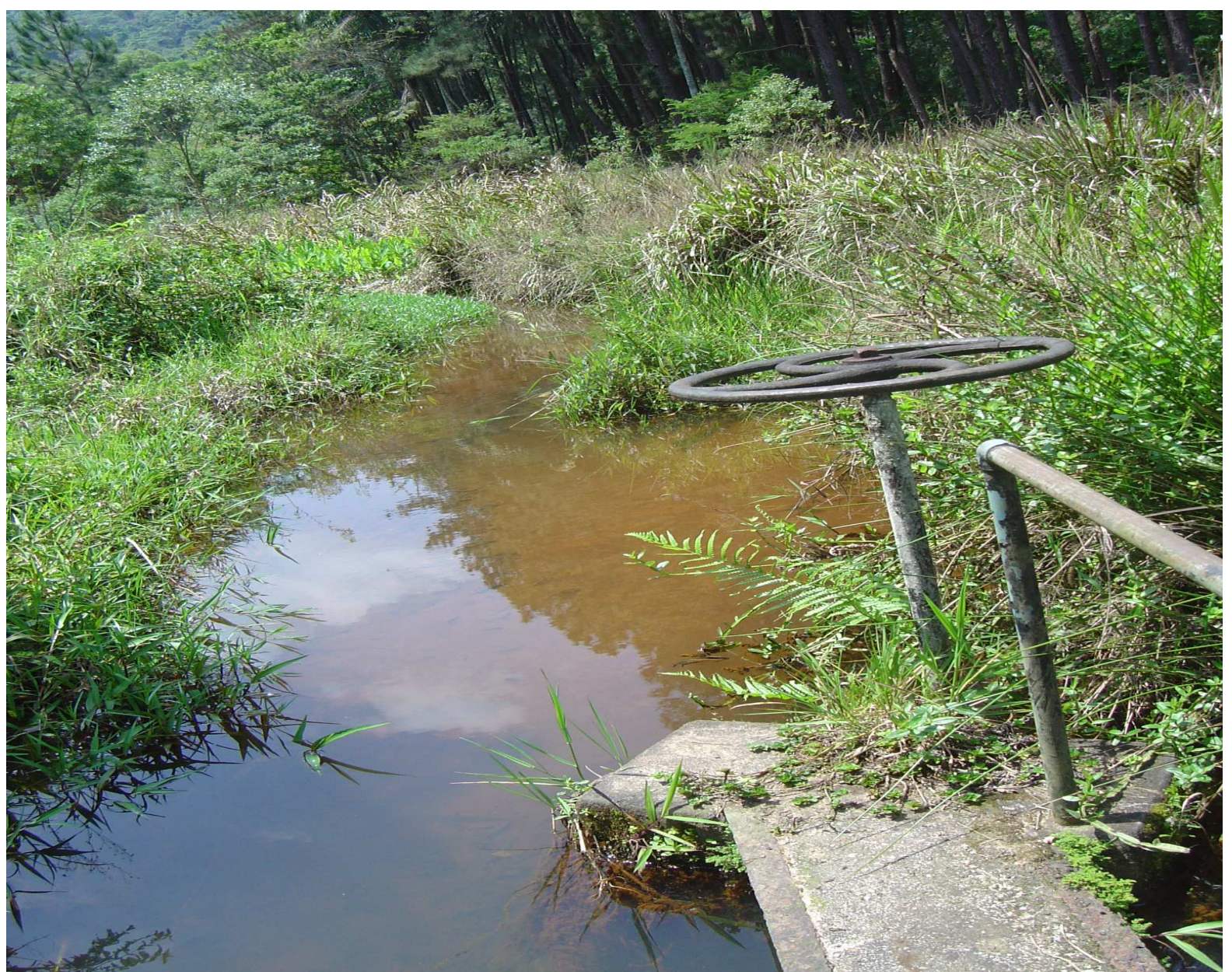

Foto de outubro de 2006, volante para a manobra da comporta ao final do passadiço. 


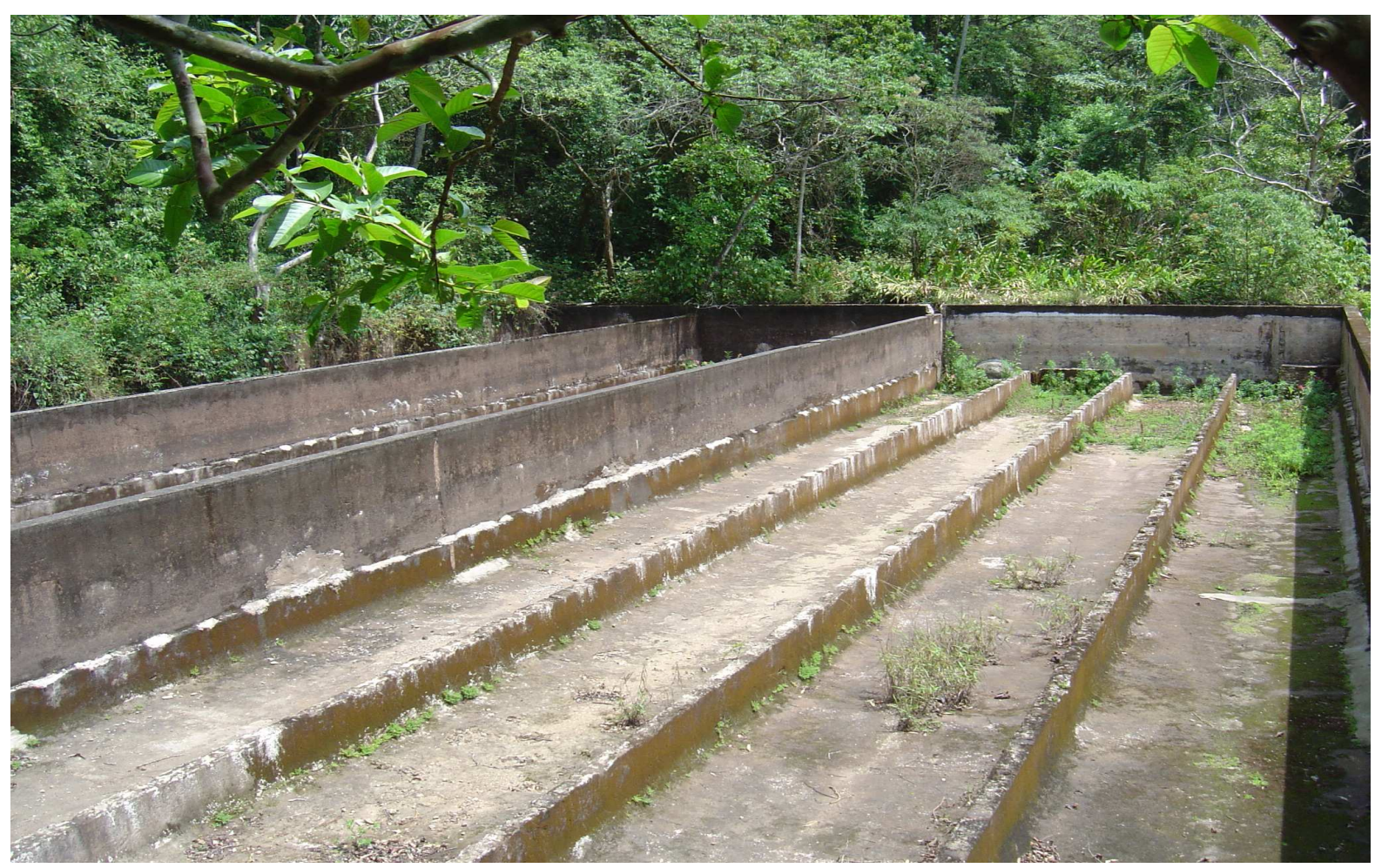

Foto de outubro de 2006, do clarificador do Barrocada

No Barrocada também foi instalado parte do sistema de filtros de areia Puech Chabal, que como se observa ainda está bem preservado, com o canal para a entrada da água, e os compartimentos onde se depositavam as partículas sólidas, de dimensões e densidade diversas, conforme o material de sua composição, em suspensão no líquido. 


\subsection{Represa e lago artificial do Cabuçu}

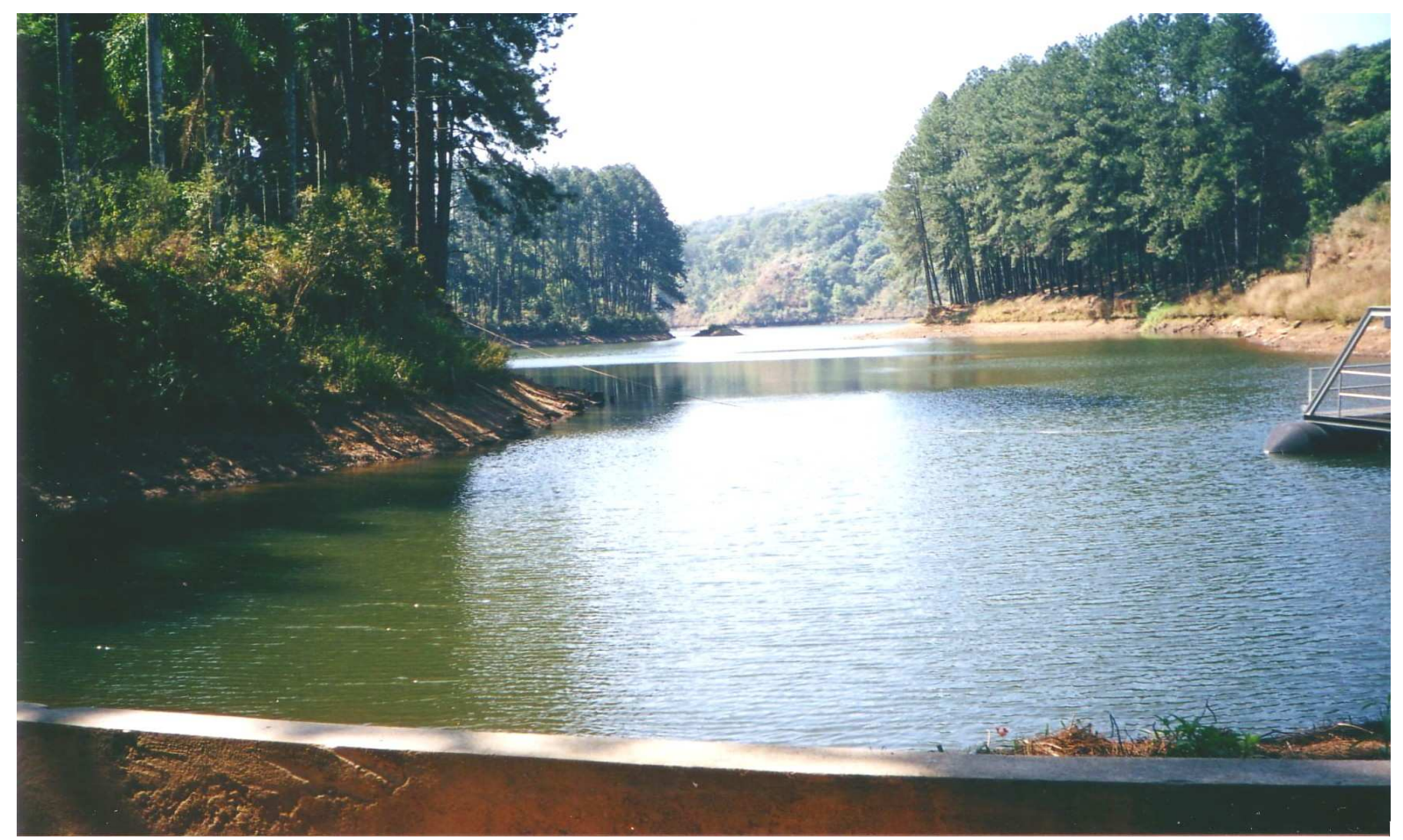

Lago artificial, foto de maio de 2005.

A barragem do Cabuçu está situada nas coordenadas U.T.M. 365.407/7.429.273 e foi construída, como já dissemos, em um estreitamento brusco do vale, do rio do mesmo nome, com capacidade para armazenar 5.000.000 de metros cúbicos de água. 


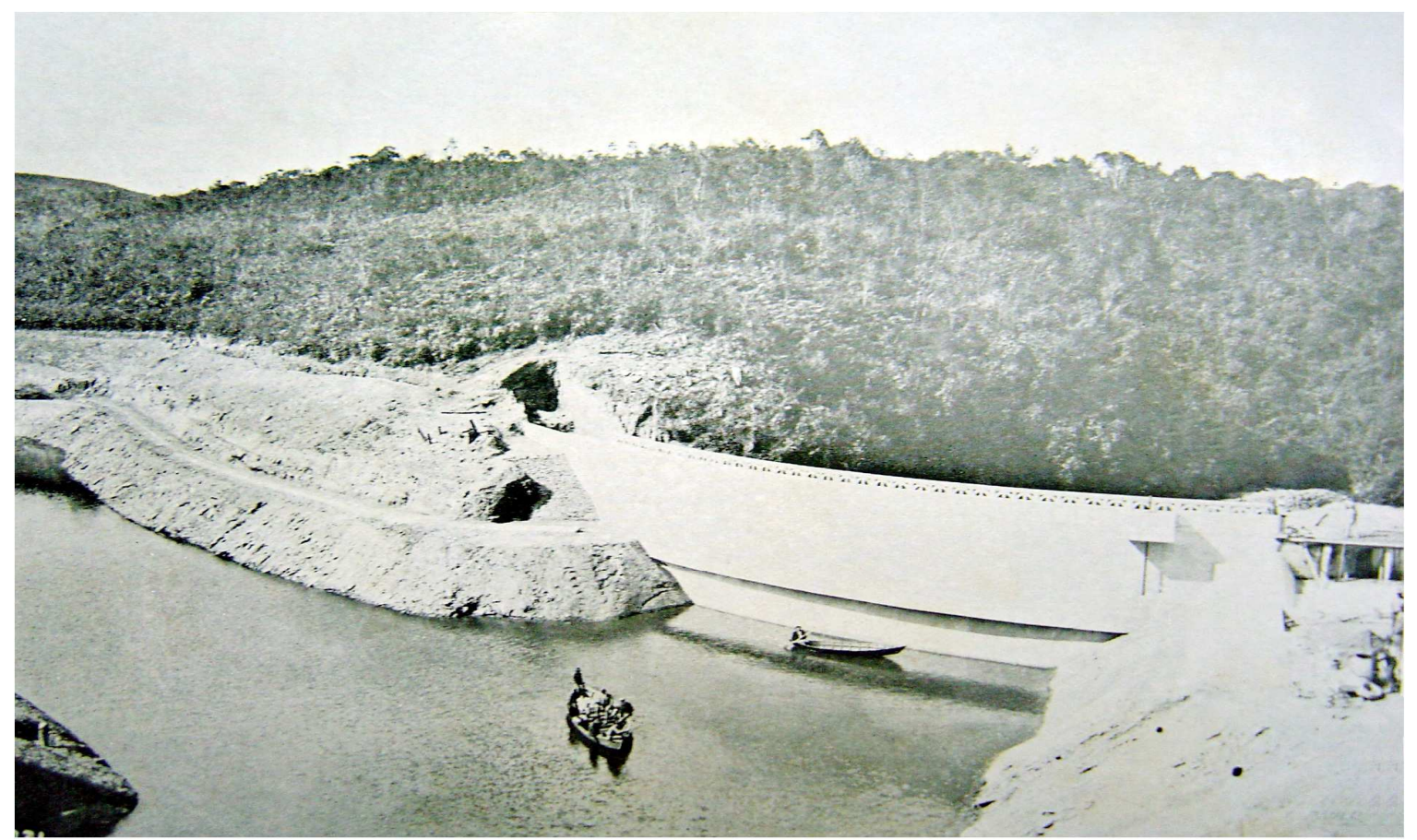

Lago artificial do Cabuçu, in Relatório da R.A.E., de 1906/1907. Acervo do Arquivo do Estado de São Paulo.

Tinha por objetivos principais, elevar a cota inicial das águas, armazená-las e purificá-las através dos decantadores os chamados "degrossisseurs", depois passálas por filtros lentos, garantindo, assim, segundo o diretor da Comissão de Obras Novas, o novo abastecimento da cidade em épocas de estiagens mais rigorosas, como as que até então tinham assolado a cidade de São Paulo.

No reservatório do Cabuçu, do total do volume armazenado, 1.960 .000 litros eram destinados a uniformizar a descarga da linha adutora. Ainda hoje a área inundada pela barragem mede $15 \mathrm{~km}$, e a maior sessão transversal 850 metros.

O Reservatório do Cabuçu, localiza-se no rio Cabuçu de Cima, na área do Parque Estadual da Cantareira, onde foi construído um núcleo ambiental para visitação pública, resultado de uma parceria entre o Instituto Florestal, da Secretaria de Estado do Meio Ambiente, o SAAE (Serviço Autônomo de Abastecimento de Guarulhos) e o CDR-Pedreira (Centro de Disposição de Resíduos). 


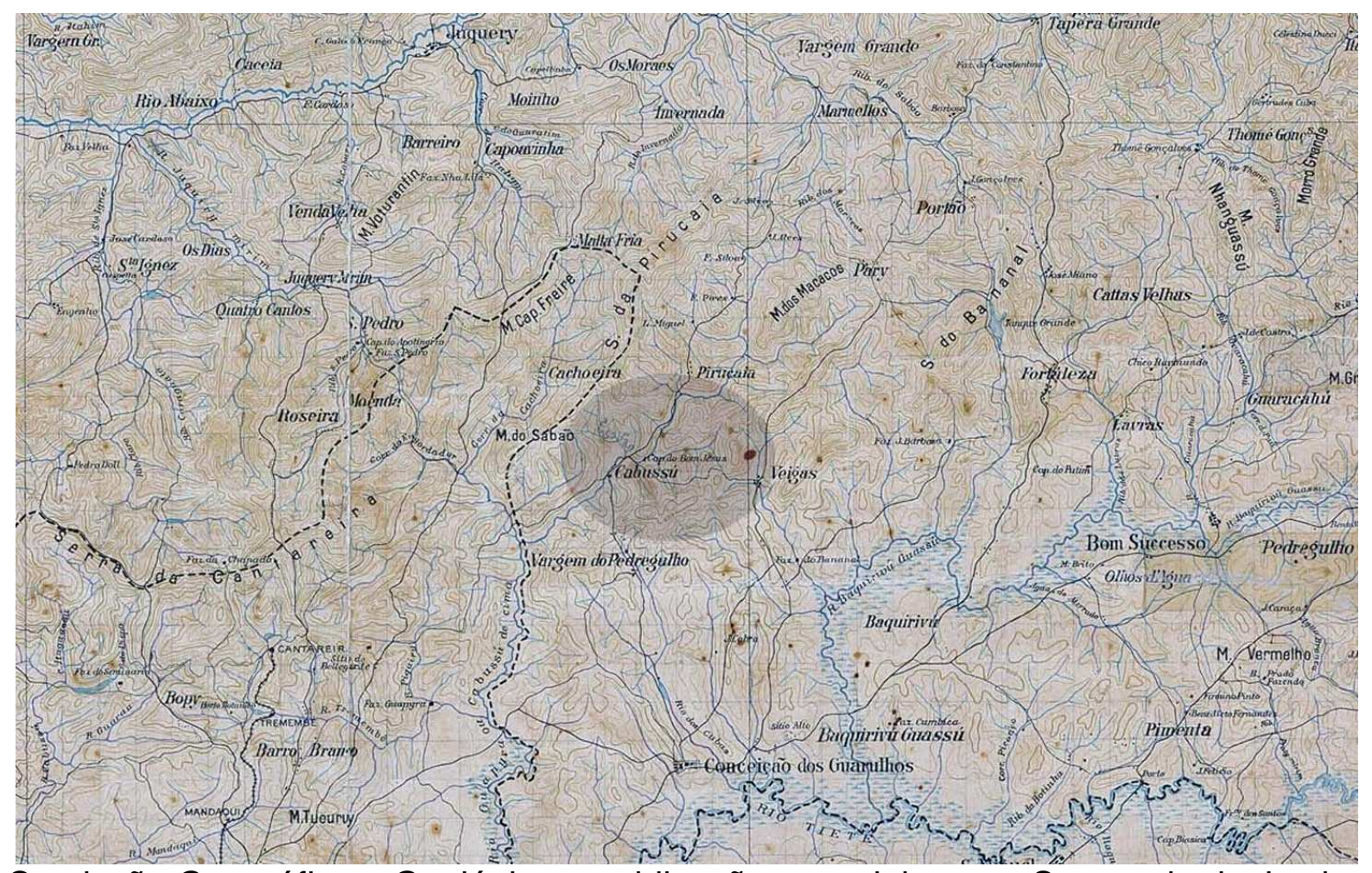

Comissão Geográfica e Geológica - publicação especial para a Secretaria da Justiça e Segurança Pública - Folha do Município da Capital. Escala 1:100 000. Acervo do Instituto Geográfico e Cartográfico. Obs. no detalhe, o rio Cabuçú de Cima, em 1904, antes da construção da barragem.

O acesso ao núcleo se faz pela Rodovia Fernão Dias até a Casa de David, (Km 80 sentido SP-BH), seguindo-se pela Estrada do Barrocada até a Estrada do Cabuçu n.․ 2.691, Jardim Monte Alto, Guarulhos - São Paulo.

Assim como outras glebas que hoje formam o parque, boa parte da Bacia do rio Cabuçu foi desapropriada, para compor a área a ser protegida pelos mananciais do abastecimento. Em junho de 1907, iniciou-se a construção da barragem do Cabuçu, que funcionou por mais de 60 anos, sendo desativada quando entrou em operação o atual sistema Cantareira, na década de 1970. 


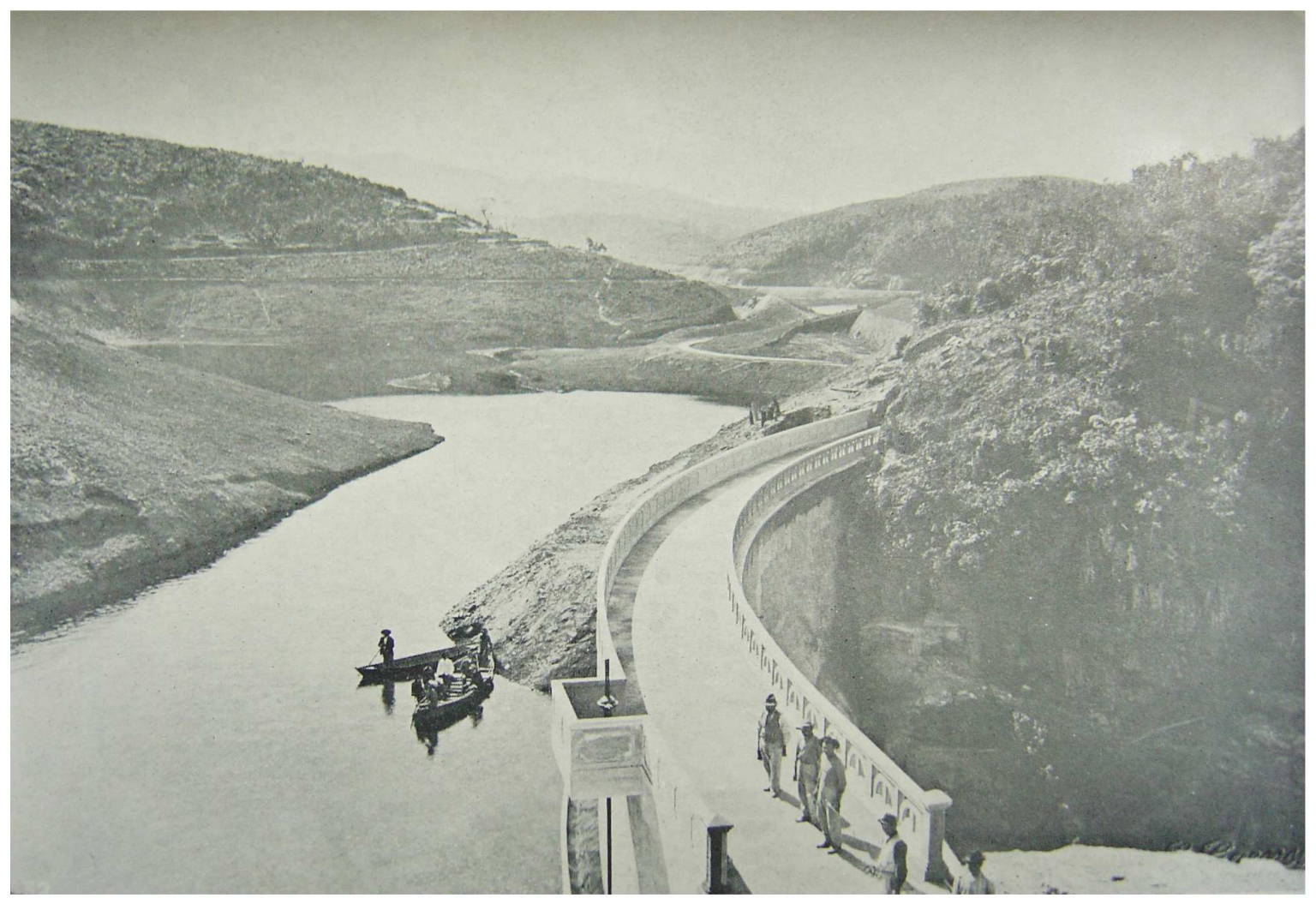

Foto do peril da barragem in Relatório da R.A.E., de 1906/1907. Acervo do Arquivo do Estado de São Paulo.

A construção da barragem para a formação do lago artificial do Cabuçu, segundo os relatórios de 1906, não havia sido iniciada até 31 de Dezembro desse ano, em razão da oposição dos proprietários da pedreira de onde deveriam ser extraídos os materiais necessários à obra, embora as fundações já estivessem assentadas, e instalados os aparelhos mecânicos para a manipulação da pedra, e os serviços para sua extração e transporte.

Em meados de 1907, havia sido concluída também a primeira limpeza da bacia alagada, bem como, estava em vias de conclusão, o canal descoberto que construído a montante da barragem, permitiria o aproveitamento das águas do ribeirão do Cabuçu, antes da conclusão total da obra, e na ocasiões em que a limpeza do lago fosse necessária.

A longa permanencia da agua nos açudes velhos ou amadurecidos, que mais não são do que verdadeiros lagos, permitte que ellas se decantem soffram a acção benefica do sol e dos ventos e naturalmente se esterilizem de tal sorte, que um simples arejamento, com pequena addição. (BRITO, 19--) 
O reservatório do Cabuçu foi construído com funções definidas, como regulador da descarga, impedindo as variações de volume de uma para outra estação do ano, como meio de decantação, reduzindo o depósito dos materiais em suspensão, e como recurso de super elevação do nível de água, no local da captação.

A inauguração solene da barragem contou com as presenças de Manoel Joaquim de Albuquerque Lins, oitavo presidente do Estado de São Paulo, de Antonio Candido Rodrigues, Secretário da Agricultura, e do Diretor da Repartição de Águas e Esgotos de São Paulo, Arthur Motta, e realizou-se em Junho de 1908, data em que se iniciou a formação do lago.

Quando o reservatório foi inaugurado, o jornal O Estado de São Paulo, em manchete anunciava: "Água para o ano 2000"194, mas o tempo desmentindo a matéria, mostrou que ela seria insuficiente para a Capital, em razão do extraordinário crescimento da metrópole paulistana.

O pioneirismo e o utilitarismo da obra ainda se fazem presentes, uma vez que estudos recentes demonstraram a viabilidade do reaproveitamento de suas águas, para suprir a demanda de parte do Município de Guarulhos.

Porém, até meados de 1909, a barragem não havia formado a totalidade do lago para o qual havia sido construída, em razão de vários fatores; os técnicos tiveram necessidade de manter a descarga aberta, para não afogar um canal que passava em forma de gaveta, aderente ao maciço da barragem, e que conduzia as águas do ribeirão do Cabuçu para a cidade; outro agravante, já relatado, foi o desmoronamento dos taludes da represa, que punha em sério risco a estabilidade da obra de concreto; e finalmente, a má qualidade da água detectada através de exames químicos e bactgeriológios, tornava-a imprópria ao consumo, o que determinou que o lago fosse completamente drenado, permanecendo vazio durante os últimos meses desse ano ano.

Somente em 1911, as águas do Cabuçú começaram a fazer parte do abastecimento de água da camada menos favorecida da população, que por longos anos sofreu com sua falta, e com sua qualidade duvidosa, quer pela visão estreita

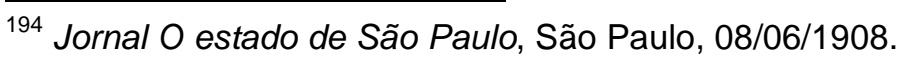


de alguns, a incompetência de outros, e a demagogia de muitos, que fizeram com que essa necessidade de direito inconteste, ficasse durante largo tempo sem atendimento.

\subsubsection{Recuperando um Patrimônio}

Segundo a Portaria no 59 de 18 de agosto de 1993, o superintendente do Departamento de Águas e Energia Elétrica (DAEE), com fundamento nos artigos nós. 36 e 45, do Decreto Federal no 24.643 de 10 de Julho de 1934, (Código de Águas), combinado com os incisos $1^{\circ}$ do artigo 21 , e $1^{\circ}$ e $7^{\circ}$ do $\operatorname{artigo} 4^{\circ}$ do regulamento dessa Autarquia, aprovado pelo Decreto $n=52.636$, de 3 de fevereiro de 1971, com a alteração introduzida pelo Decreto $n ² 3.933$ de 18 de setembro de 1985, com a Portaria DAEE no 39 de 23 de junho de 1986, dando solução ao requerimento constante nos autos 39.198 Prov. 1 - o DAEE determina:

Artigo $1^{\circ}$ - Fica concedido ao SAAE, de Guarulhos, para atendimento público daquele Município num prazo de 30 anos o uso das águas: do manancial do Cabuçu, para fins de abastecimento público até 300 litros por segundo.

Do manancial do Barrocada, para fins de abastecimento público até 120 litros por segundo.

Em 1999, o Serviço Autônomo de Água e Esgotos (SAAE) de Guarulhos, tomou várias medidas, tendentes a fornecer os elementos necessários, para a elaboração do projeto de reativar o funcionamento do reservatório do Cabuçu, reforçando assim o abastecimento de água do Município de Guarulhos.

Desse projeto fizeram parte, consultas à carta geológica da Região Metropolitana de São Paulo, e a planta com o arranjo geral das obras do barramento, relatório dos perfis de sondagem, levantamentos de campo, planialtimétricos, aerofotogramétricos e outros, visando à coleta de dados indispensáveis ao diagnóstico da situação real em que se encontrava a barragem, e os procedimentos técnicos que a viabilizariam, como um precioso contributo na distribuição de água à população de Guarulhos. 
A firma MS Engenharia S/C LTDA., em 2000 ${ }^{195}$, encarregada do parecer geotécnico do sistema Cabuçu, em sua avaliação, teve por base os dados do relatório do I.P.T. de № 13.054 (Segurança de Barragens) elaborando seu parecer: "trata-se de uma barragem de concreto gravidade, desenvolvida em arco, com $35 \mathrm{~m}$ de comprimento e altura máxima aproximada de $15 \mathrm{~m}$, e dotada de um vertedor lateral de soleira livre na sua ombreira direita".

\footnotetext{
${ }^{195}$ MS. ENGENHARIA S/C LTDA. Relatório de Dezembro de 2000, enviado a VELLOSO FERREIRA,
} Consultoria e projetos S/C. Ltda. 2000, São Paulo, p.1. 


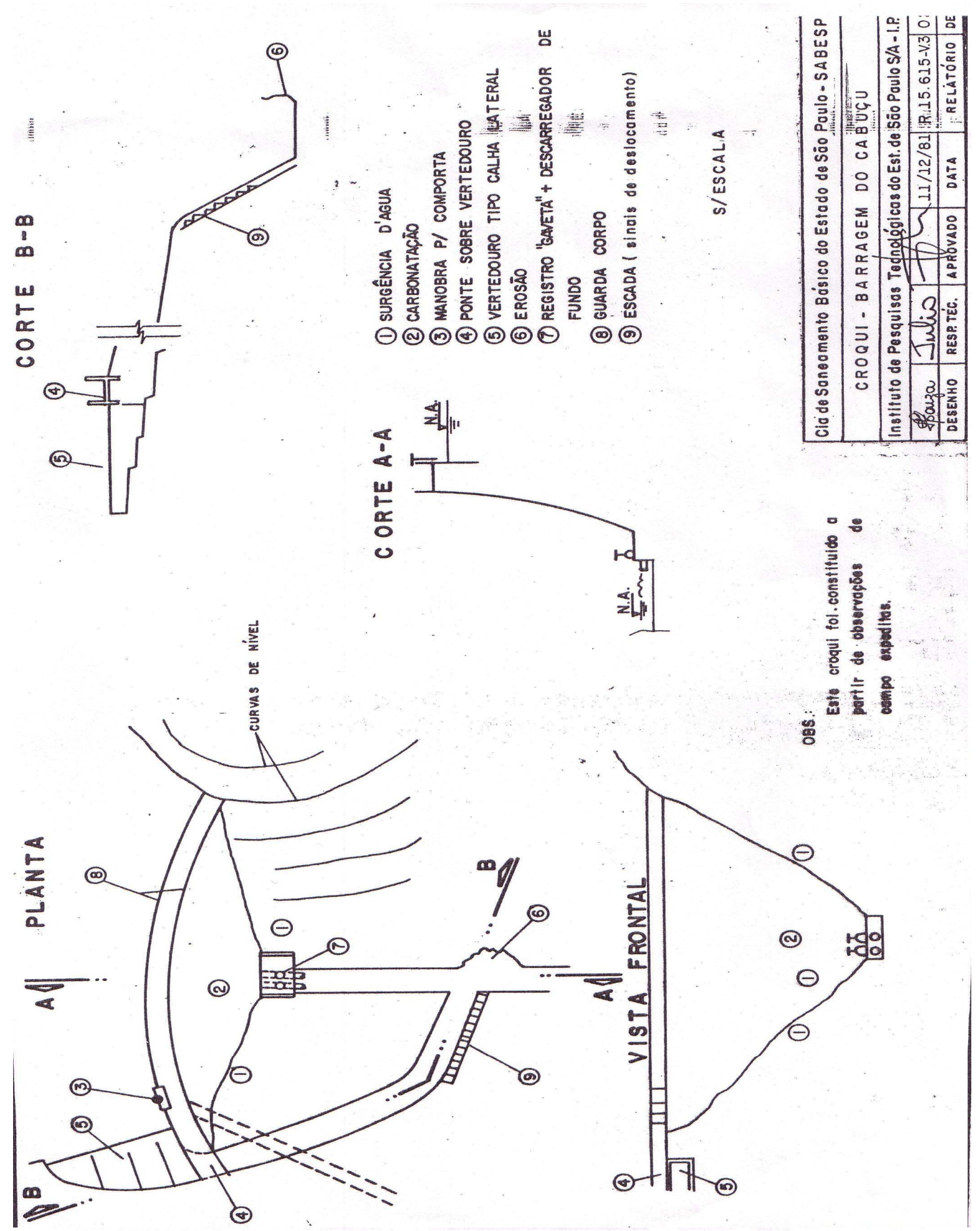

Croqui da Barragem do Cabuçu feito pelo Instituto de Pesquisa Tecnológica (IPT)

Nesse relatório está descrito o resultado do trabalho de campo, dos especialistas dessa firma de engenharia, que fizeram o diagnóstico da barragem as condições de sua fundação, assentada em um maciço rochoso, constituído de 
filito $^{196}$, sobre o qual estão alicerçadas suas bases, pouco alterado, quase são, porém, deteriorado na ombreira direita.

De acordo com os técnicos, as infiltrações de água ocorriam no corpo da barragem de concreto, na base de suas fundações, e em ambas as ombreiras. Foi detectado um aumento das vazões de infiltração, com 0 enchimento do reservatório, e observado, também, que as águas que emergiam no pé da barragem, eram límpidas, e isentas de quaisquer partículas que pudessem denunciar carreamento de materiais.

As infiltrações de água, descobertas na fundação rochosa da barragem, seguiam o modelo do meio descontínuo, havendo percolações através dos sistemas de fraturas, que se comunicavam entre si. As maiores vazões situavam-se na ombreira direita. Os técnicos observaram que, as ressurgëncias de água que ocorriam principalmente no pé do paramento de jusante da barragem, indicavam uma zona de percolação no contato da estrutura de concreto, com a fundação da barragem.

As condições da fundação pareciam adequadas, conforme os técnicos haviam observado, nos afloramentos rochosos existentes em ambas as ombreiras, o que pode ser confirmado com a execução de sondagens rotativas.

A conclusão que a comissão técnica havia chegado, era a de que a reativação dessa obra, reforçando o abastecimento do município de Guarulhos em mais de 300 litros por segundo, seria muito importante, sem dúvida para atender às necessidades da população merecendo, portanto, um melhor conhecimento do seu comportamento.

As observações que haviam levantado, e que já haviam sido detectadas e diagnosticadas pelo Instituto de Pesquisas Técnicas (IPT), mostraram não ter havido aparentemente problemas de estabilidade com relação à barragem, o que foi confirmado, através de um programa de investigação e de observação, desenvolvido por especialistas em engenharia de barragens no decorrer do tempo.

Esses técnicos consideraram a barragem aparentemente segura, com relação à sua estabilidade, uma vez que, não ocorria o deslocamento de

\footnotetext{
${ }^{196}$ Rocha metamórfica de granulação fina, originando-se em geral de material argiloso, de várias colorações: branco, rosado, cinza e preto, roxo, rosado. Devido à sua natureza química e mineralógica, pode compor até $50 \%$ de massas cerâmicas.
} 
materiais da fundação, e os problemas com as infiltrações, que haviam sido detectados, restringiam-se à perda dos volumes d'água havendo, porém, necessidade de se constatarem as reais condições de suas fundações, e de seu comportament, por ocasião do enchimento do reservatório.

De acordo com o levantamento hídrico, a captação do sistema Cabuçu era inferior a 293 litros de água por segundo, acusando, portanto, um déficit de mais de 7 litros; a conclusão do relatório foi a de que esse problema seria sanado, com a impermeabilização das ombreiras e das fundações. Para tanto, vários procedimentos foram recomendados antes do enchimento do reservatório, como por exemplo: a medição das vazões de infiltração, a verificação da tonalidade da cor da água, quanto a possíveis carreamentos de materiais, a tomada de medidas da infitração, ao longo das canaletas situadas no pé da barragem, procurando determinar as contribuições nas diferentes cotas; a execução dos serviços de reparo do corpo da barragem, (maciço de concreto), a instalação de piezômetros/medidores de nível d'água, e a realização de leituras iniciais, havendo necessidade de serem implantados, no mínimo, duas linhas de piezômetros/medidores de nível d'água". ${ }^{197}$

Durante o enchimento do reservatório, e após esse processo, o relatório orientava no sentido de novamente se medirem as vazões de infiltração, a verificação da cor da água, e a existência ou não de carreamento de materiais, como também, salientava a necessidade de se correlacionarem os volumes, e os pontos de ressurgências, com a subida do reservatório; deveriam continuar sendo medidas as infiltrações, ao longo das canaletas situadas no pé da barragem, e a verificação do nível da sub-pressão nas fundações com o enchimento total do reservatório; importante também era a determinação das condições da fundação da barragem, inicialmente nas ombreiras, sendo necessário para tanto, que se fizessem sondagens rotativas e Ensaios de Perda D’Água (EPA). ${ }^{198}$

O relatório concluíu que, somente com a realização de todos esses procedimentos, e avaliados seus resultados, seria possível determinar se haveria ou não necessidade da aplicação da cortina de injeção, e caso fosse adotada, sua execução deveria ser iniciada nas ombreiras e em seguida avaliar-se sua eficiência, através de medidas dos volumes de infiltração, e nos novos EPAs.

\footnotetext{
${ }^{197}$ Relatório da MS Engenharia S/C LTDA. São Paulo, Dezembro de 2000.

${ }^{198}$ Ibidem
} 
Apenas em função das vazões de infiltração, que poderiam ocorrer após o tratamento das ombreiras, seria possível determinar-se a necessidade de se prosseguir o tratamento, através da complementação das injeções da fundação, na região central da barragem, o que exigiria o esvaziamento do reservatório novamente. ${ }^{199}$

Foram relacionadas as instruções para a execução dos serviços, principalmente no que dizia respeito às sondagens rotativas, que deveriam ser em número de três, em cada ombreira, com espaço de quatro metros entre si, e a profundidade máxima de dez metros na rocha.

Essas sondagens necessitavam do aporte de toda a técnica disponível, para que fosse obtida a recuperação do maior número possível de testemunhos, inclusive do concreto aplicado.

A coleta obtida seria disposta em caixas de PVC, próprias para o acondicionamento das amostras, segundo normas indicadas pela Associação Brasileira de Geologia e Engenharia (ABGE).

Ao longo de todo trecho da rocha, e em todas as sondagens rotativas, deveriam ser executados ensaios de perda d'água, segundo as especificações da ABGE. Uma vez concluída a perfuração, e os ensaios de perda d'água, os furos deveriam permanecer abertos, para que pudessem ser medidos os níveis d'água, e posteriormente o próprio controle da eficiência das injeções.

A firma de engenharia utilizaria como metodologia de execução, na cortina de injeções, a aplicação em um única linha, ficando em aberto a possibilidade de acréscimo de outras linhas, em função dos resultados que fossem obtidos.

Os trabalhos, segundo a previsão, seriam executados em duas etapas, inicialmente nas ombreiras, e posteriormente no trecho central da barragem, sendo de fundamental importância, que a cortina fosse executada segundo um plano contínuo, dentro do corpo da fundação e nunca diretamente no maciço rochoso a montante da barragem.

Os serviços de injeção nas ombreiras, deveriam ser iniciados através de sondagens rotativas, numeradas de SR 1 a SR 6, com um espaçamento de quatro metros entre si, e realizados preliminarmente ensaios de perda d'água, para que uma orientação mais segura norteasse a execução dessas injeções, de calda de cimento, sempre mais ralas no início da operação. Outros aditivos, como por

\footnotetext{
${ }^{199}$ Ibidem
} 
exmplo a betonita ${ }^{200}$, a pozolona ${ }^{201}$, e até mesmo a areia, poderiam ser eventualmente agregados, em função das absorções da calda, e cujos ensaios estariam relatados no controle de qualidade dos serviços prestados.

Com relação ao centro da barragem, seriam aplicados os mesmos procedimentos, apenas com um espaço maior, de oito metros, entre as sondagens rotativas.

As injeções deveriam sempre ser executadas nos trechos ascendentes, e excepcionalmente, nos descendentes, quando as condições do maciço rochoso assim o exigissem, e realizadas com equipamentos completos e apropriados aos serviços como misturadores, agitadores, bombas de injeção, registros, mnômetros, engates, obturadores e outros.

\subsubsection{Trabalho de Campo}

As fontes escritas, o relatório da MS Engenharia S/C LTDA, e o croqui da barragem feito pelo I.P.T., forneceram informações complementares, que associados aos registros fotográficos antigos permitiram, no trabalho de campo, levantar os dados da construção da barragem, suas modificações e intervenções, capacidade de armazenamento, e suas medidas.

\footnotetext{
${ }^{200}$ Nome genérico de uma espécie de argila bastante maleável de granulação fina, composta principalmente de silicato de alumínio hidratado.

${ }^{201}$ Pozolanas (naturais, provenientes das cinzas de vulcões, ou artificiais, fabricadas); por tratar-se de um material pegajoso, é adicionado ao cimento para dar liga.O nome vem da cidade italiana de Pozzuoli onde são encontradas as cinzas vucânicas.
} 


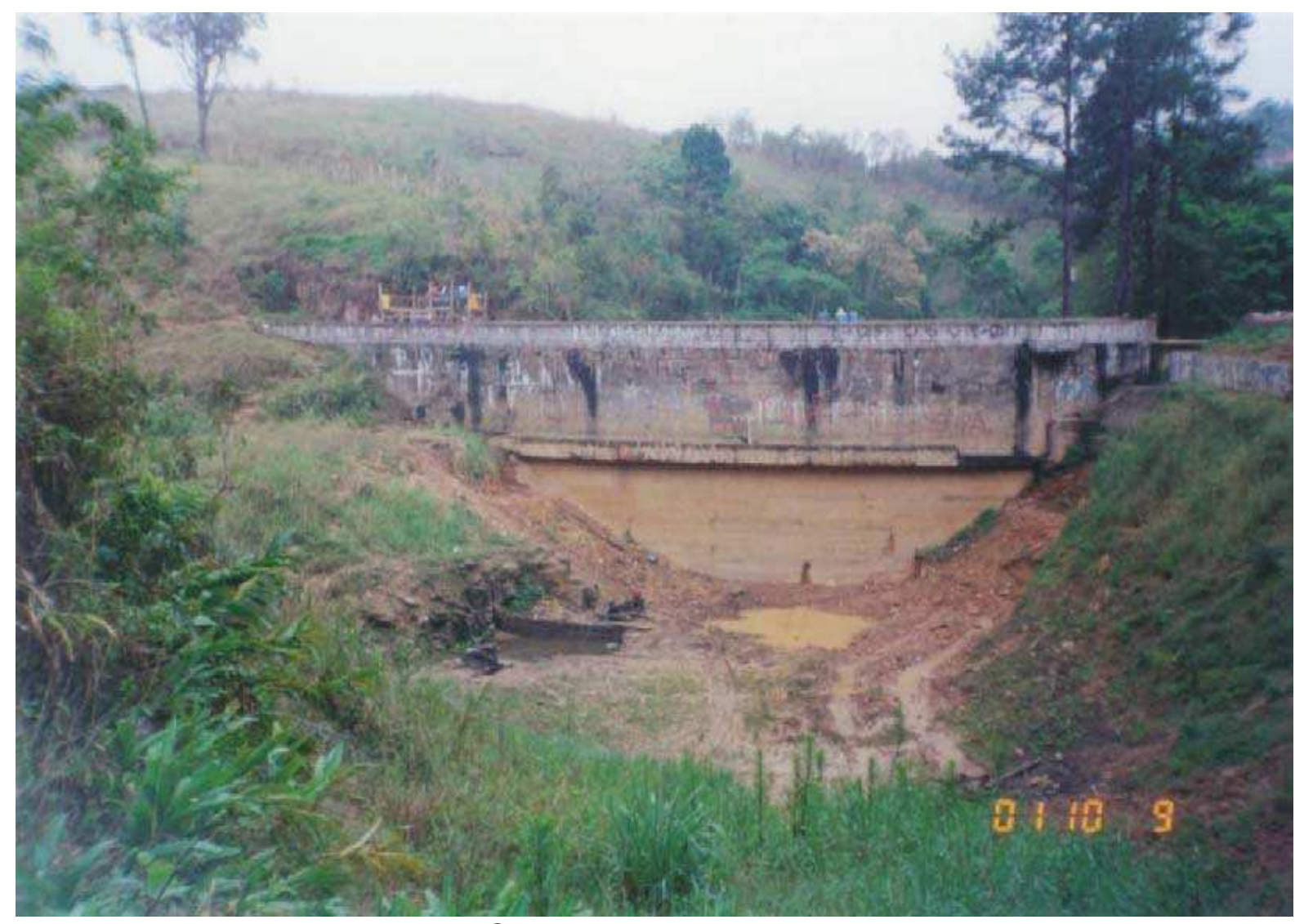

Foto da barragem do Cabuçu, 2001. Acervo Hagaplan Engenharia

$\mathrm{Na}$ seqüência das fotos datadas de 2001, pode-se observar o estado de deterioração que a barragem se encontrava depois de quase três décadas de abandono. A firma de engenharia Hagaplan, foi a encarregada das obras de recuperação da barragem do Cabuçu, que foi precedida por um diagnóstico de suas condições, e a técnica que deveria ser adotada para superar seus problemas, conforme já foi visto. 


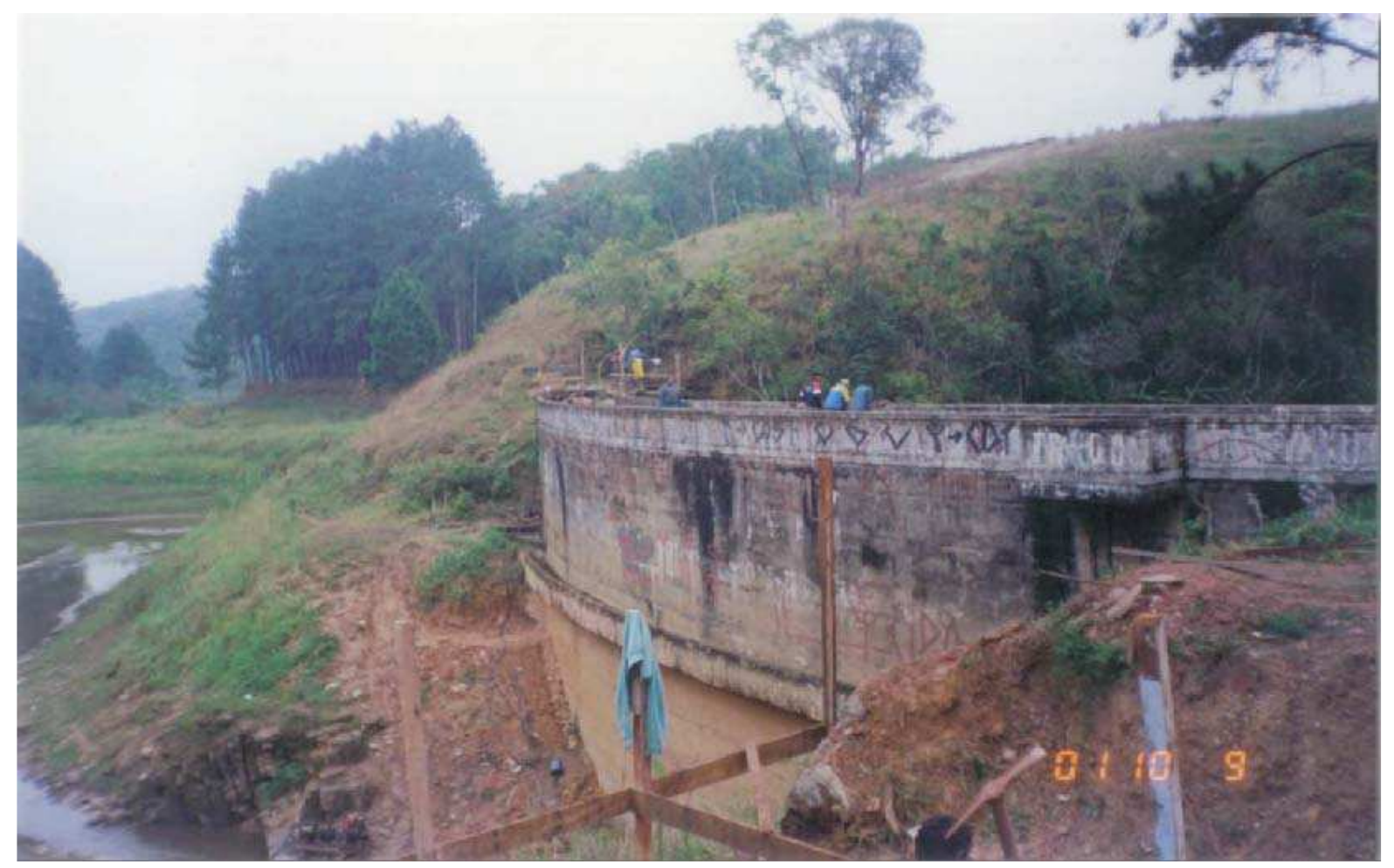

Foto de 2001, acervo Hagaplan.

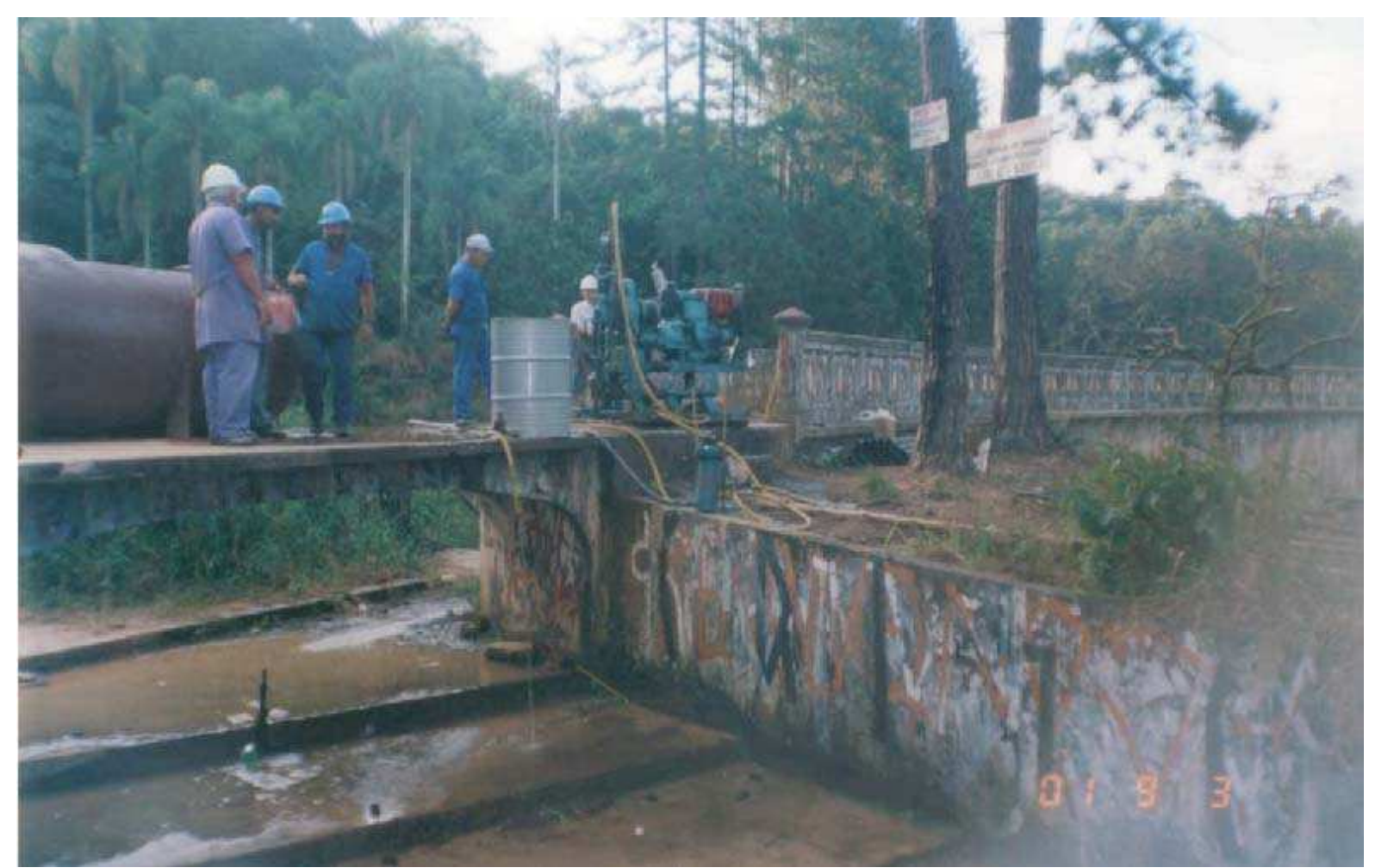

Foto de 2001, acervo Hagaplan. 
Detalhe das condições em que se encontrava o vertedouro da barragem semi-destruído, cujas obras de restauro estavam se iniciando.

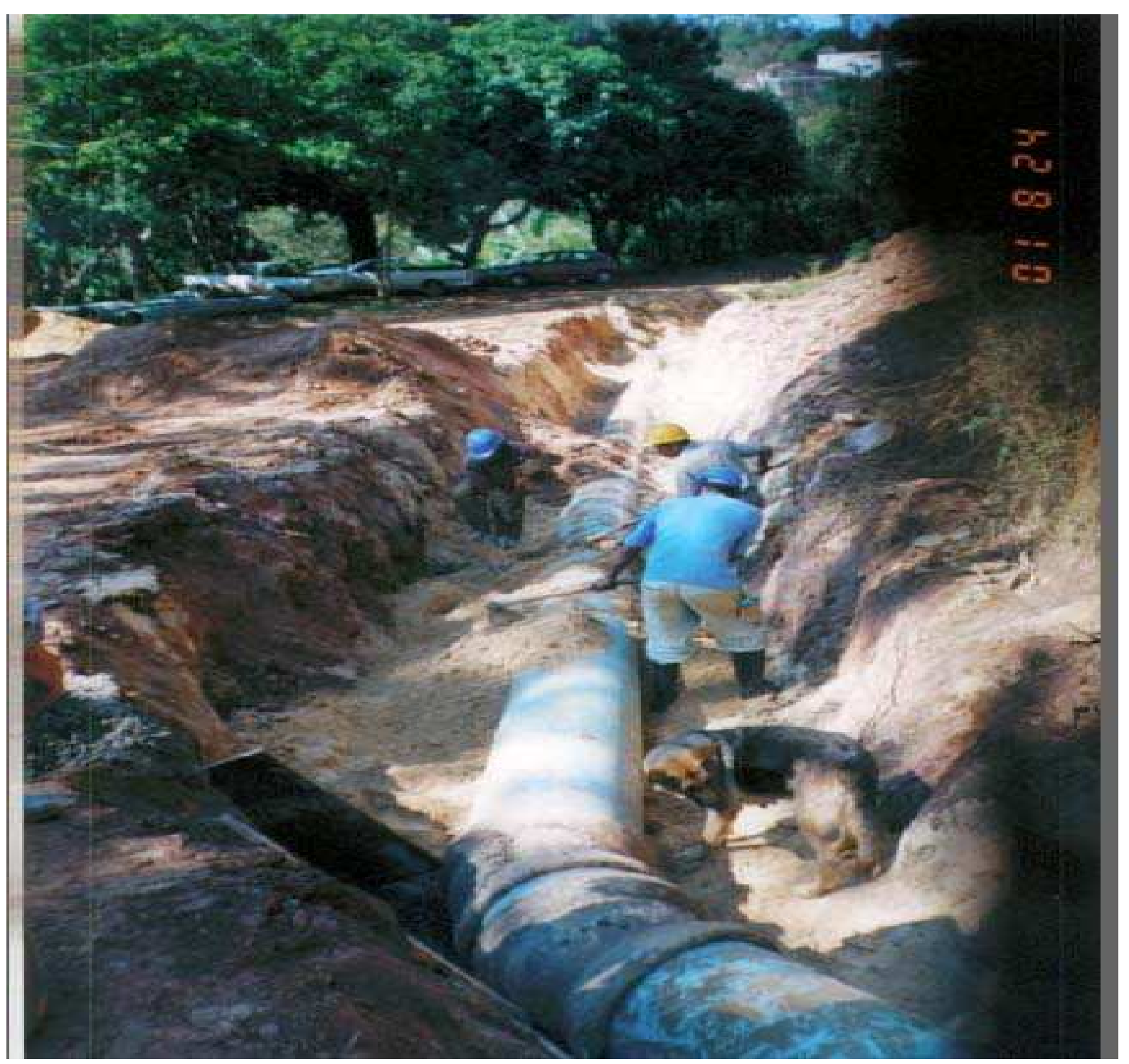

Foto de 2001, acervo Hagaplan Engenharia.

Colocação da nova adutora, em ferro fundido, levando as águas para seu destino, o Município de Guarulhos, em substituição à anterior em concreto armado, que chegava com sua enorme extensão até a cidade de São Paulo. 


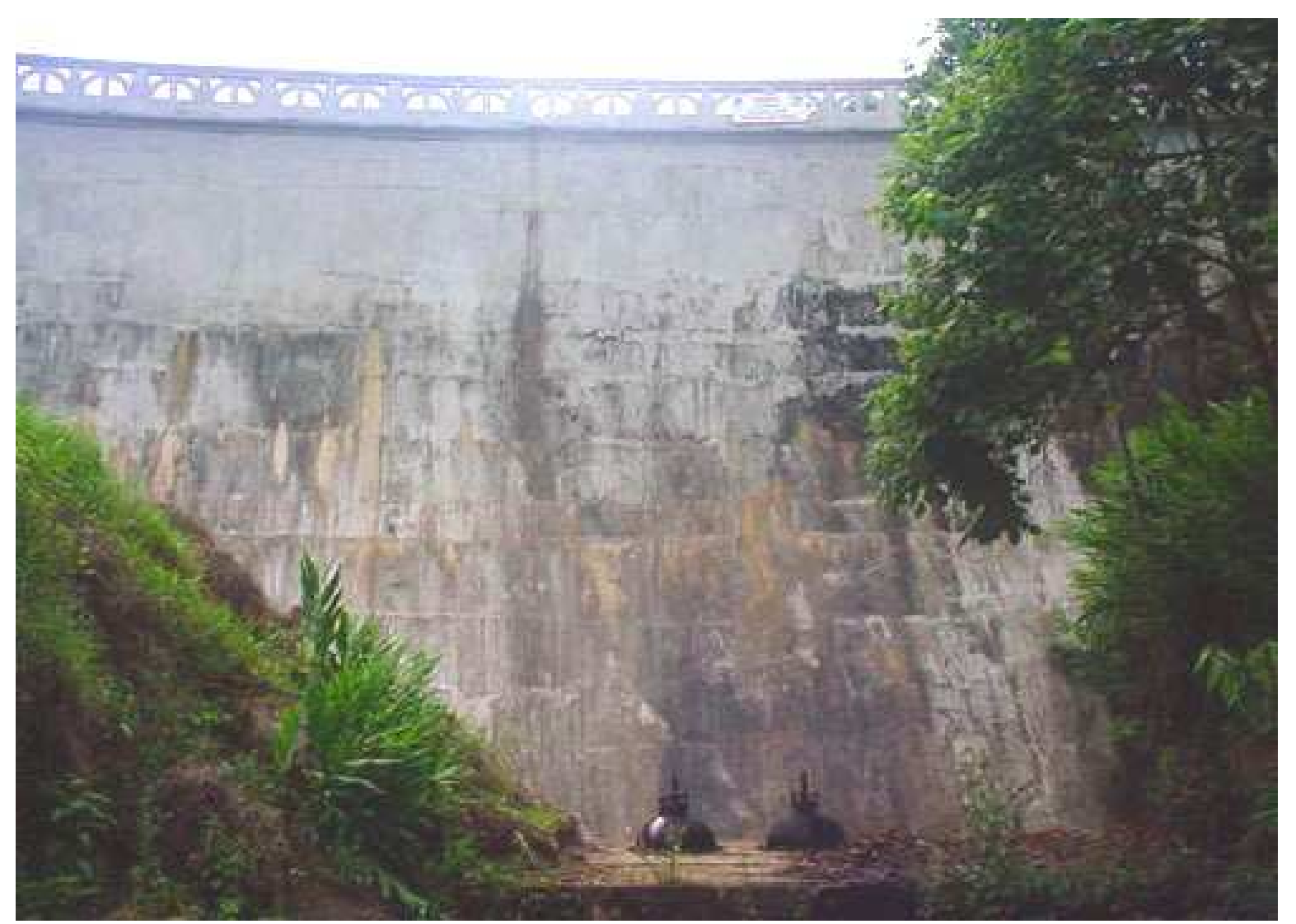

Foto de maio de 2005.

$\mathrm{Na}$ foto fica demonstrada a grandiosidade da parede da barragem com 15 metros de altura, vendo-se os dois registros de gaveta. 


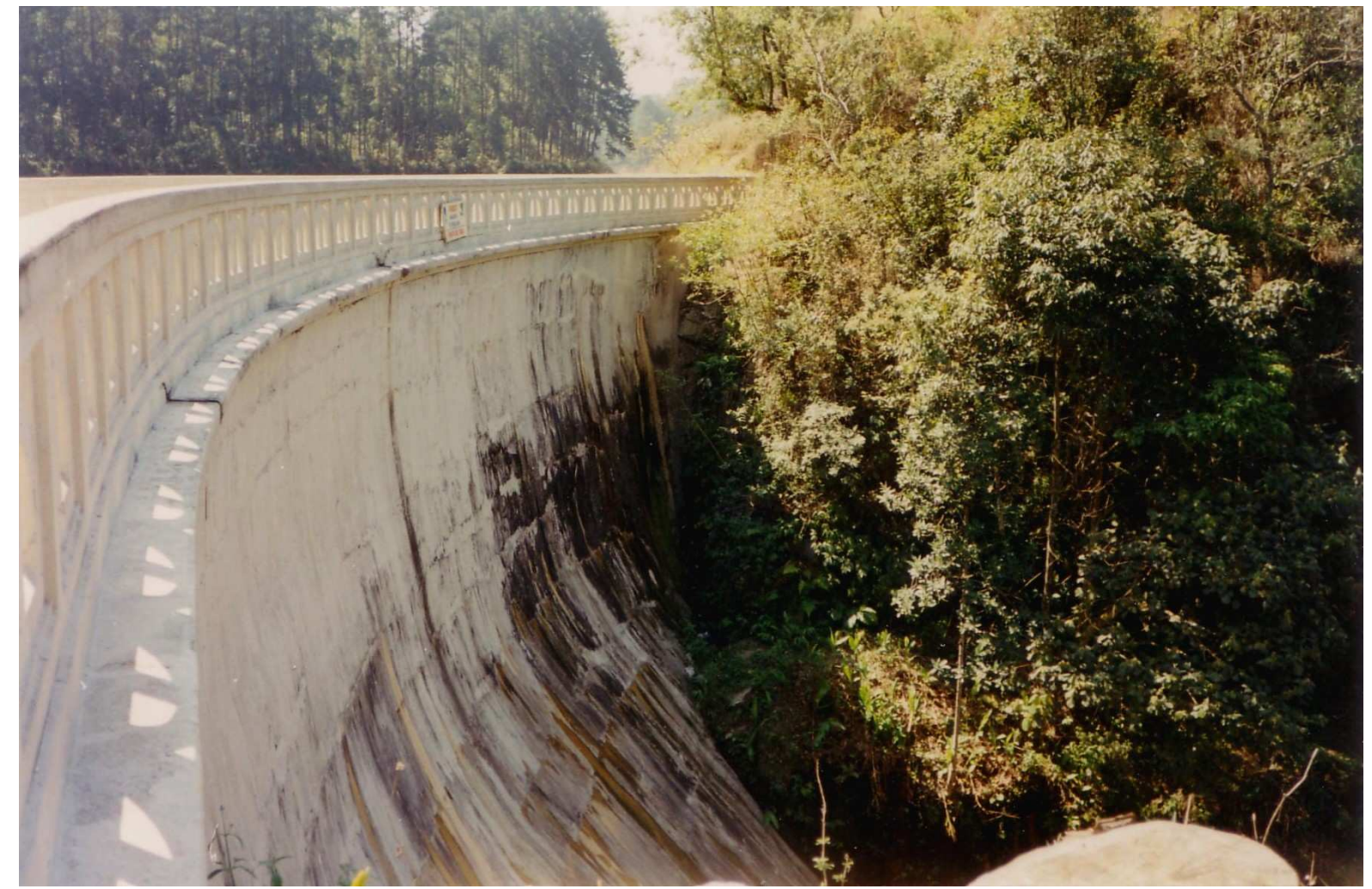

Foto de maio de 2005.

Pode-se notar perfeitamente pelo registro fotográfico que, apesar de todas as intervenções sofridas pela barragem, o corrimão no coroamento da barragem e seu perfil elíptico foram restaurados, mantendo-se a forma original desde a época de sua inauguração. 


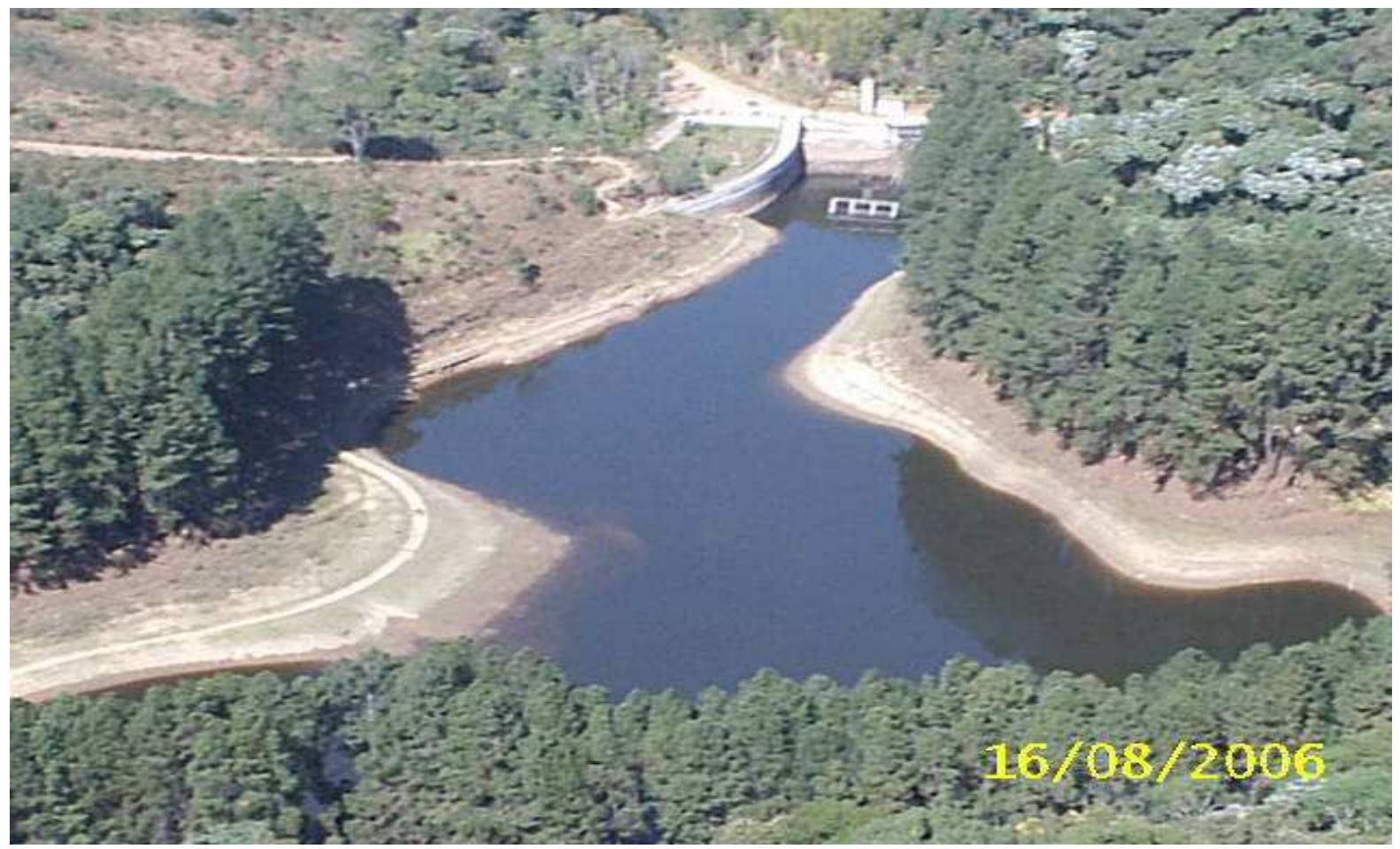

Foto, acervo S.A.A.E. Guarulhos. Vista aérea do interior do reservatório, à esquerda a barragem, totalmente recuperada.

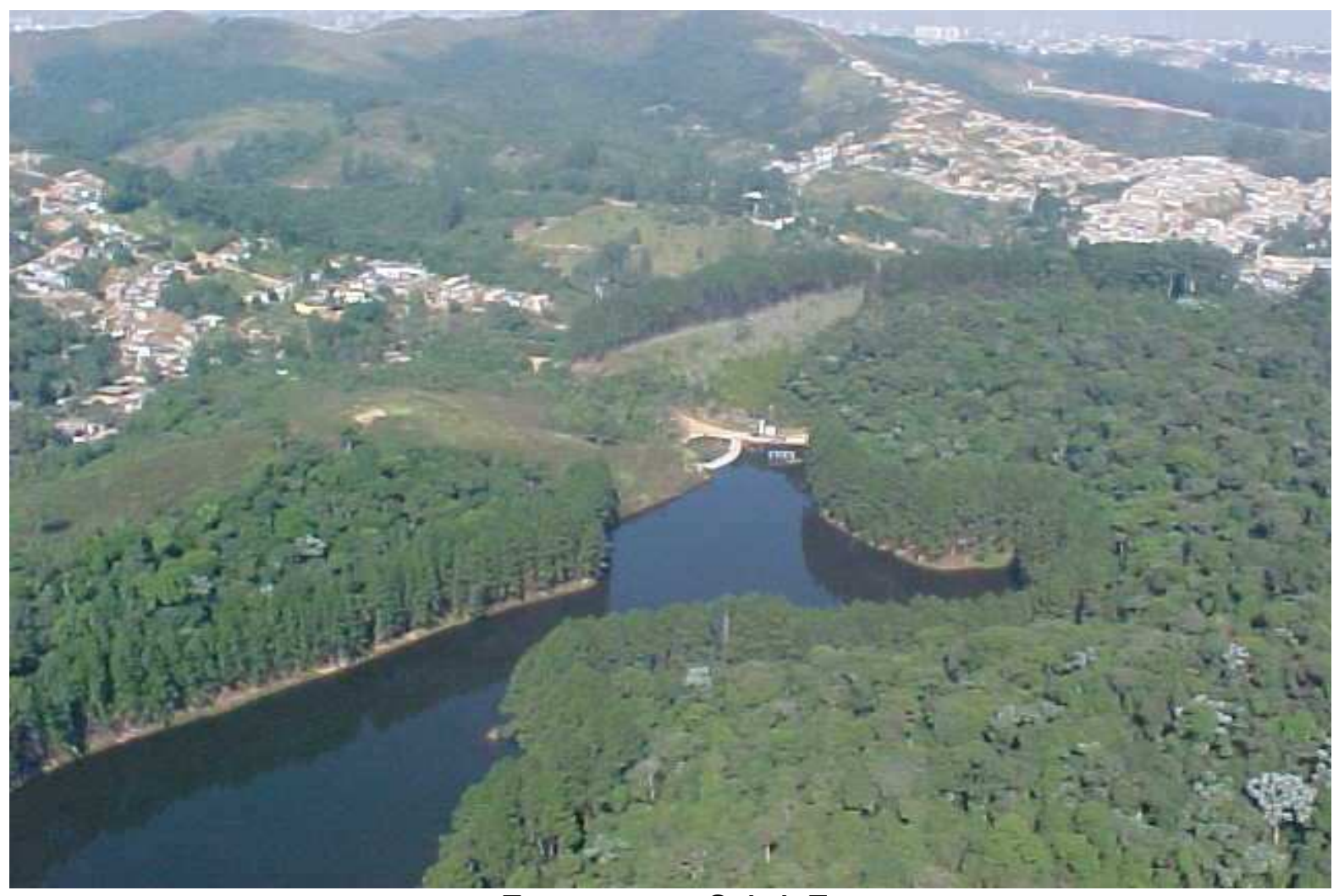

Foto, acervo S.A.A.E. 
Em primeiro plano, o avanço desordenado dos bairros da cidade de Guarulhos, perigosamente próximos à barragem, e ao fundo, a metrópole paulistana.

\subsubsection{Concreto armado: construção Pioneira}

As barragens de acumulação são obras de engenharia, que se estendem transversalmente de uma margem a outra de um curso d'água, destinadas a criar em um reservatório um lago artificial, o que permite armazenar as águas no período de cheias, para poder utilizá-las em épocas de estiagem, garantindo, entre outras utilidades, o abastecimento nesses períodos, a geração de energia elétrica, a normalização da vazão minimizando os efeitos das cheias, e criando lagos para diversas atividades.

De acordo com o material utilizado em sua construção elas podem ser de terra, (solo), enrocamento, concreto, e concreto armado, que é uma estrutura obtida através de uma camada de cimento, reforçada por barras de ferro ou aço.

O concreto moderno, utilizado na construção dos mais diversos tipos de estrutura, é fruto do trabalho de inúmeros homens, que durante muitos anos observaram a natureza, e se esmeraram em aperfeiçoar materiais, técnicas, teorias e formas estruturais. Seu desenvolvimento, a partir do século XIX, é justificado pelas grandes vantagens que oferece, como maior garantia de durabilidade, impermeabilidade e rapidez de execução, trata-se, portanto, de uma técnica que dá bons resultados em obras hidráulicas, fundações, galerias de esgotos, entre outras.

Nos sistemas construtivos, a necessidade de aumentar a resistência da pedra ou argamassa, associando a elas barras metálicas, remonta ao tempo dos romanos, quando nas escavações arqueológicas das termas de Caracala, em Roma, notou-se a existência de barras de bronze dentro da argamassa das pozolanas. Espécie de cinza vulcânica arenosa fina, a pozolana, foi originariamente descoberta e retirada de Pozzuoli na região em torno do Vesúvio, Nápoles, muito usada nas antigas construções de alvenaria, como nas termas romanas, e na Via Apia Antiqua; essa espécie de argila, por si só, não tem valor aglomerante, porém, quando misturada com água e cal, age como o nosso moderno cimento. ${ }^{202}$

\footnotetext{
${ }^{202}$ VASCONCELOS, Augusto Carlos, de. O concreto no Brasil. Ed.JAG.Composições e Artes Gráficas Ltda.São Paulo, 1985, p.8.
} 
O concreto foi encontrado na construção dos muros de uma antiga cidade romana, do século IV a.C, situada a $64 \mathrm{~km}$ de Roma, e no século II a.C., esse novo material começou a ser usado em grande escala nas edificações da cidade. ${ }^{203}$

Em 1849, na França, o engenheiro francês Joseph Louis Lambot, foi o pioneiro no emprego do ferro com o cimento, como elemento estrutural, criando o cimento armado, invenção essa que deu origem ao moderno concreto armado; utilizou para sua experiência os dois materiais, ferro e cimento, nas caixas de laranjas, e nos reservatórios de água, em Miraval, no Var, sul da França, onde morava.

Pouco depois, em 1850, construiu um barco de concreto armado, cuja experiência pioneira consistia em introduzir uma malha de barras finas de ferro, ou arame, entrelaçadas com outras, mais grossas, seguras em uma argamassa. Essas malhas finas que serviam de estrutura para a obtenção do formato adequado de uma canoa, dispensavam o uso de moldes complicados e dispendiosos, e evitava os problemas com as fissuras ${ }^{204}$. O engenheiro francês patenteou sua invenção, e apresentou-a o na Feira Internacional de Paris de 1855.

A divulgação dessa técnica, porém, se deve ao outro francês Monier, (detentor da patente em 1867), e o aprimoramento de seus aspectos teóricos ao americano Hyatt, e aos alemães Wayss e Koenen. ${ }^{205}$

Les supports horizontaux armaturés en fer et ciment, sont le nouveau système a pour but d'augmenter la résistance des pièce de charpente tells que solives, poutres, et planches, etc. ${ }^{206}$

Essa revista de agosto de 1899, publicou um estudo baseado no que foi apresentado por Maurice Levy em sessão de 5 de agosto de 1895 na Academia de Ciências de Paris, sobre o revestimento de cimento armado nas barragens, criando um tipo de muro de guarda, para evitar acidentes que eram comuns neste tipo de obra. Nesta ocasião, o engenheiro apresentou à assembléia algumas considerações sobre as grandes barragens, no que dizia respeito às condições de subpressão ou pressão ascendente e a aplicação de cimento armado para aumentar a resistência de suas paredes.

\footnotetext{
${ }^{203}$ Ibdem

${ }^{204}$ No museu nacional de Brignoles, está conservado o protótipo original de sua invenção.

${ }^{205}$ Ibidem, p.8/9.

${ }^{205}$ In Nouvelles annales de la construction. Revue Techonologique.Ed.Paris. Paris, Août. 1899, Le

Gérant: Ch. Béranger, p. 16.
} 
Outra vantagem desse revestimento, segundo a mesma fonte, é a sua ligação com os tubos de tomadas d'água e de descarga também projetados com esse mesmo material, o que faz desaparecer as soluções de continuidade e com elas os pontos críticos e as infiltrações.

A propósito do emprego desse material nas canalizações, são importantes os trabalhos feitos na Alemanha pelo Laboratório Imperial de Ensaios sobre Materiais de Construção em Berlim, nos primeiros anos do século XX, o Congresso de Estradas de Ferro realizado em Washington em 1905, e o Boletim o 7 da Sociedade dos Engenheiros Civis da França de Julho de 1905 que concluíram:

Lê beton armé permet d'executer les travaux rapidement, au moyen de materiaux de vente courante, em evitant aussi la necessité onéreuse en pratique, de recourir a de commandes especiales aux usines. $^{207}$ (LEME, 1906)

O cimento usado no Cabuçu, era transportado em barris de madeira, e foi empregado na construção do reservatório e em toda a extensão da adutora, que ligava a captação das águas do ribeirão, à Estação de Tratamento de Água do Mirante de Santana, na Capital.

\footnotetext{
${ }^{207}$ LEME, Luiz, Betim Paes. O Abastecimento de Agua Á Capital. In Revista Polytechnica de 1906. Typographia do "Diário Official”, São Paulo, 1906, p.191.
} 


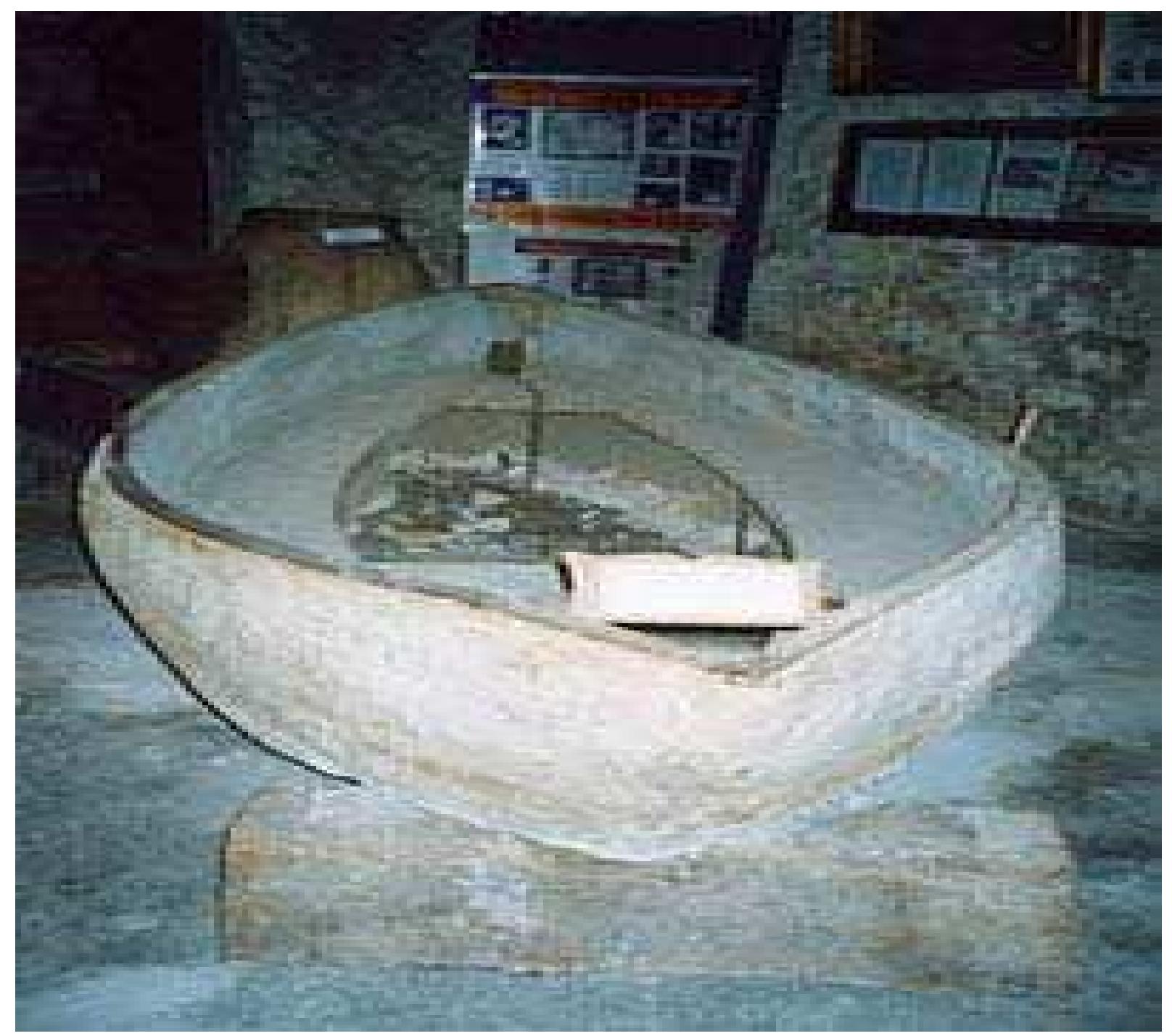

Museu nacional de Brignoles, onde está conservado o protótipo original da Invenção de Lambot. ${ }^{208}$

O concreto armado é utilizado em grande escala para construir muitos tipos de estruturas, como represas, auto-estradas, ruas, pontes, grandes edifícios, pistas de aterrissagem, sistemas de irrigação e canalização, molhes, embarcadouros e cais, calçadas, silos ou celeiros, fábricas, casas e até barcos.

Provocou uma revolução na engenharia brasileira, que não teria condições de realizar obras tão significativas, apenas com estruturas metálicas. O aço importado era caro, e não havia uma indústria montada para produzi-lo aqui. Outro fator determinante de seu sucesso, diz respeito também à mão de obra, operários sem qualificação, conseguiam facilmente fazer a massa no chão da obra e aplicá-la às ferragens.

${ }^{208}$ In Enciclopédia Tecnologia Planetarium. Ed. Roma Planetarium, Roma, 1976, vol. II, p.246. 
O concreto é um produto resultante da mistura de aglomerantes, os cimentos; a preferência recai sobre o portland artificial, de pega lenta, por ser o mais resistente.

Do latim caementu, o material hoje empregado, e desenvolvido pelo químico inglês Joseph Aspdin, que requereu sua patente em 1824, é uma composição química, cujo nome se deve à semelhança de sua cor e ao tipo de uma pedra (portlandstone) encontrada na ilha de Portland, sul da Inglaterra.

No Brasil, seu fabricante, o major Proost Rodovalho, em 1888 , instalou em sua fazenda uma unidade de fabricação, porém sem nenhuma linha regular de produção, o que ocorreria somente em 1926, com a Cia. de Cimento Portland Perus.

Agregados miúdos e graúdos, também fazem parte de sua composição, como areia, pedrisco, seixo e brita; a areia deve ser de grãos resistentes e não excessivamente pequenos que exigem muita água e fornece argamassa de fraca resistência;

Os aditivos do concreto, que são os retardadores de pega, os plastificantes redutores de água, e os incorporadores de ar, os mais usados são os minerais de ferro, de bário chumbo e outros, que fazem aumentar de forma linear a pressão do concreto. São aditivos prontos para o uso, indicados quando uma demora no período de pega é requerida, para garantir tempo suficiente para o transporte e o lançamento do concreto.

Quanto à água para amalgamá-lo, deve ser a mais pura, a água de beber, doce e limpa.

O concreto armado tem elevada resistência, tanto aos esforços de tração, como aos de compressão, mas para isso precisa de um importante componente: a armadura de ferro, também chamada de ferro de construção ou vergalhões. Têm a propriedade de se integrar ao concreto, e de apresentar elevada resistência à tração. Por isso, são colocados nas partes da peça de concreto que vão sofrer esse esforço.

Produto da revolução industrial, é o resultado de uma mescla de uso de maquinários: betoneiras, vibradores, bombas lançadoras, com a execução artesanal das estruturas de alvenaria: preparo manual das fôrmas e do escoramento, dobramento e amarração das armaduras, cura e desforma.

Com relação às primeiras aplicações do concreto armado no Brasil, ou cimento armado como era chamado até 1920, a mais antiga referência data de 
1883, quando Giuseppe Rossetti, um empreiteiro italiano apresentou um projeto à edilidade paulistana para a realização de uma ponte de concreto armado, que não teria sido aprovado, em razão do total desconhecimento da nova técnica construtiva pelos engenheiros que foram então consultados. ${ }^{209}$

Em São Paulo, os primeiros usos do concreto armado, durante a constituição do chamado "complexo cafeeiro", são contemporâneos à sua aplicação e difusão na Europa, e estão associados à necessidade de uma nova estrutura urbana, envolvendo empresas públicas e privadas, na realização de obras de saneamento, melhoria de transportes e de energia, na perspectiva de melhor equipar a sociedade paulistana, para receber o século vinte que se aproximava.

Para atingir tal objetivo, havia necessidade de uma ampla gama de profissionais, engenheiros e técnicos responsáveis pelo projeto, cálculo, análise e controle dos materiais, além de estudos laboratoriais, que dessem suporte à adoção dos novos processos de transferência, de adaptação e posteriormente o domínio da produção dessa técnica em São Paulo, possibilitou grandes transformações nos processos de trabalho na indústria da construção civil, por exigir uma organização industrial nas obras.

Papel importante nessa conjuntura, desempenhou o Gabinete de Resistência dos Materiais, da Escola Politécnica de São Paulo, criado em 1899 e sua posterior transformação em 1926, no Laboratório de Ensaios de Materiais ${ }^{210}$, destinado a complementar a parte teórica dos cursos de engenharia, e possibilitar a execução de estudos experimentais, ou pesquisas técnicas, de acordo com a terminologia usada na época.

O concreto armado, como nova técnica construtiva, embora enfrentando algumas resistências, foi incorporado com certa facilidade e rapidez pelos nossos engenheiros, formando-se a escola brasileira do concreto armado, que alterou a visão dos nossos profissionais com relação à construção civil, de um simples observador de construção a um dos profissionais mais perfeitos do mundo, nas palavras também do Prof. Noronha. ${ }^{211}$ (TELLES, 1984)

\footnotetext{
${ }^{209}$ TELLES, Pedro Carlos da Silva. História da Engenharia no Brasil (Século XX), Ed. Livros Técnicos e Científicos, Rio de Janeiro, 1984, p.473.

${ }^{210}$ Transformado depois, em 1934, no Instituto de Pesquisas Tecnológicas do Estado de São Paulo.

${ }^{211}$ TELLES, Pedro Carlos da Silva. História da Engenharia no Brasil (Século XX), Ed. Livros Técnicos e Científicos, Rio de Janeiro, 1984, p, 484.
} 
O Professor Antonio de Paula Freitas, em seu curso na Escola Politécnica do Rio de Janeiro em 1904, menciona os primeiros casos em que foram realizadas construções de cimento armado, de acordo com o projeto do engenheiro Carlos Poma, detentor da patente Monier ${ }^{212}$, desde 1892, que construiu seis residências em Copacabana, onde fundações, paredes, vigamentos, soalhos, tetos, escadas e muros, eram de concreto armado. Esse profissional foi encarregado também, de construir em Petrópolis, um pequeno reservatório com o mesmo material.

O professor Paula Freitas, menciona também, o revestimento do túnel João Ayres, no quilômetro 350 da Serra da Mantiqueira, feito originariamente de terra argilosa, e desmoronada a 12 de janeiro de 1901, tendo sido substituído por uma galeria de madeira, cujo revestimento foi de cimento armado. ${ }^{213}$

Embora tenham sido executadas outras construções do mesmo gênero, eram em menor escala, e sem nenhuma especificação. Diante dessas pesquisas históricas, levantou-se a hipótese, alicerçada na afirmativa do professor Pedro Carlos Da Silva Telles ${ }^{214}$, de que foi a construção do Reservatório do Cabuçu, a primeira grande obra de concreto armado do Brasil. ${ }^{215}$

Nessa obra, terminada em junho de 1908, houve um pioneirismo notável, que foi a aplicação em larga escala do concreto armado, pela primeira vez no Brasil, em edificações desse tipo. Eram de concreto os reservatórios, as cortinas de proteção das barragens, a torre de distribuição, a adutora, que somava quase dezessete quilômetros de extensão e os próprios tubos pressurizados dos sifões, que tinham um metro de diâmetro e uma carga hidrostática de $27 \mathrm{~m} .^{216}$

Embora o conhecimento sobre o novo material fosse ainda muito pequeno, a construção foi considerada uma das mais importantes da engenharia do começo do século $\mathrm{XX}$, um sucesso da tecnologia paulistana, apesar de terem ocorrido alguns contratempos, como já se disse, plenamente justificados pelo seu pioneirismo, e devidos exclusivamente ao revestimento metálico, e não ao concreto armado.

\footnotetext{
${ }^{212}$ Cessão de direitos ao uso da técnica do concreto armado.

${ }^{213}$ FREITAS, Antonio de Paula. Construcções em Cimento Armado. In Revista dos Cursos da Escola Politécnica do Rio de Janeiro, Ed. da Escola Politécnica, Rio de Janeiro, 1904. vol I,

${ }^{214}$ Engenheiro pela Escola Nacional de Engenharia, no Rio de Janeiro, professor da Escola de Engenharia da U.F.R.J. e do Instituto Militar de Engenharia. Consultor técnico do Instituto Brasileiro de Petróleo e Engenheiro aposentado da PETROBRAS.

${ }^{215}$ TELLES, Pedro Carlos da Silva. História da Engenharia no Brasil (Século XX), Livros Técnicos e Científicos Ed., Rio de Janeiro, 1984, p.316.

${ }^{216}$ Pressão e equilíbrio de líquidos ou gases que se submetem à lei da gravidade.
} 
Os problemas que surgiram, estavam ligados à impermeabilidade das juntas entre os tubos dos sifões.

(...) foi colocado um revestimento interno de chapas galvanizadas, que eram soldadas entre si; as soldas apresentaram defeitos, e os vazamentos eram grandes, de forma que o sistema só pode entrar em serviço depois de refeitas todas as juntas com argamassa de cimento, portanto, não se tratava de erro no concreto armado. ${ }^{217}$ (TELLES, 1984)

Essa obra, foi chefiada pelo engenheiro Luiz Betim Paes Leme, diretor da Comissão de Obras Novas de Saneamento e Abastecimento de Água da Capital, formado na Europa, e considerado um dos introdutores do concreto armado em São Paulo.

Nas palavras do engenheiro Hyppolyto Gustavo Pujol Jr., "métodos de cálculo imprecisos e às vezes contraditórios, o material primitivo e impróprio, as nervuras pesadamente armadas com ferros duplo "T", mas trata-se de cimento armado, não obstante". 218

Nos primeiros anos do século $X X$, foram realizados ensaios de resistência de diversos materiais de construção, inclusive de cimentos, cujo resultado foi a publicação pelo Grêmio Politécnico em 1905 do "Manual de Resistência dos Materiais", que contou com a colaboração desse insigne engenheiro, que recém formado iniciou estudos metalográficos e análise de materiais, tendo em vista 0 emprego das barras de aço no concreto armado.

Os métodos de análise da metalografia, complementaram e aprofundaram a pesquisa sobre o concreto armado, considerado emblemático na paisagem urbana paulistana de então. Sem esses estudos, a aplicação dessa nova técnica seria mais difícil, uma vez que entre seus componentes, é o metal que suporta os esforços de tração.

A influência do novo material se fez sentir na arquitetura, com novas e arrojadas formas de construção, como foi o caso do primeiro edifício de concreto armado do Brasil, de 1909, construído na esquina da rua Direita com a de São Bento, e cujo projeto se deve ao arquiteto italiano Francesco Notaraberto. O prédio

\footnotetext{
${ }^{217}$ TELLES, Pedro Carlos da Silva. História da Engenharia no Brasil (Século XX), Livros Técnicos e Científicos Ed., Rio de Janeiro, 1984, p.316

${ }^{218}$ Ibidem, p.475.
} 
tinha inicialmente dois pavimentos, aos quais foram acrescentados um terceiro e um torreão no ângulo.

Embora ilustres engenheiros como Ramos de Azevedo, de início tivessem muita prevenção e dúvidas quanto à aplicação da nova técnica, acabaram se rendendo às evidências de sua praticidade, durabilidade e facilidade de aplicação, utilizando-a, posteriormente, em centenas de importantes obras espalhadas pela cidade.

$\mathrm{Na}$ economia paulistana, sua presença também se fez sentir, com $\mathrm{O}$ surgimento de serviços e atividades complementares dessa nova tecnologia, surgindo, por via de conseqüência, as primeiras firmas construtoras, escritórios de arquitetura e engenharia, paralelamente a um expressivo comércio de materiais de construção 


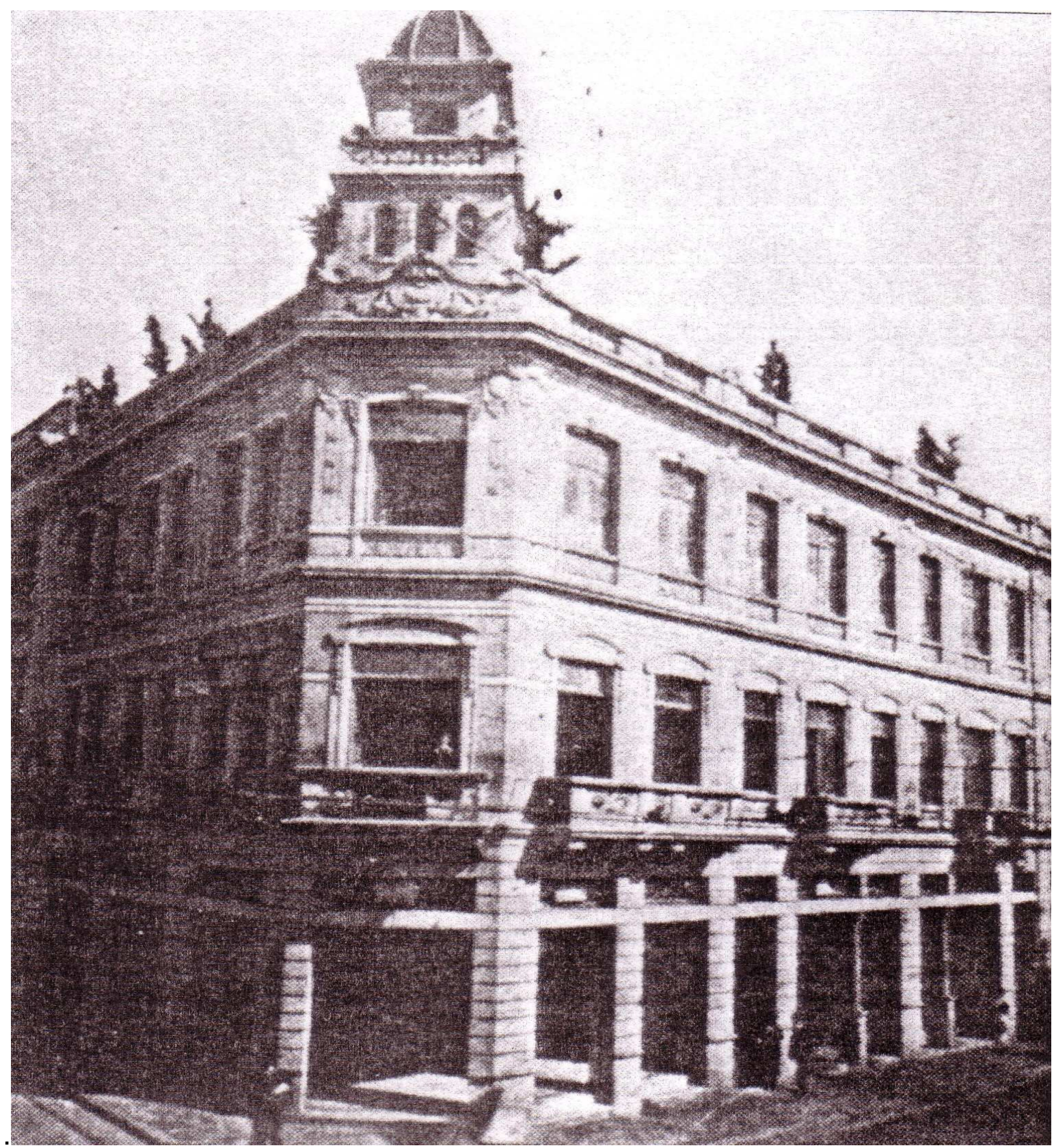

Prédio de concreto armado na rua São Bento (1909), do livro "O Concreto no Brasil Recordes, Realizações, História" de Augusto Carlos de Vasconcelos. Coleção do autor

\subsection{Tratamento da água}

Desde os tempos mais remotos da história da humanidade, quando o homem deixa de ser nômade, e se agrupa em vilas e cidades, existe uma associação íntima entre sua habitação e a proximidade de rios fontes, mananciais e outros suprimentos de água. 
Já se tem dito que através dos tempos, "depois da paixão do amor, os direitos sobre a água causaram mais distúrbios que qualquer outro motivo de interesse da espécie humana". 219

À medida que o tempo foi passando, e com o surgimento da revolução Industrial, os agrupamentos humanos atingiram proporções gigantescas, e sua proximidade dos suprimentos de água, vetor de graves epidemias constituiu, não apenas o elemento essencial à vida, mas também o veículo da morte, pela facilidade com que a água dissemina pragas e doenças, promovendo rapidamente suas propagações, dizimando populações inteiras. Isso porque, a mesma água que recebe os dejetos humanos e de animais, é utilizada pelo homem para beber e lavar seus alimentos, roupas, objetos, e o próprio corpo.

Por essa razão, a procura da água para a sobrevivência, foi gradualmente comparada ao empenho na obtenção de "água pura". As definições de pureza variaram através dos séculos, à medida que os consumidores se tornaram cada vez mais sofisticados na sua compreensão e exigência.

A análise da potabilidade da água consumida era feita de maneira empírica, produto da simples observação de indivíduos, considerados experts, que distinguiam as águas boas, das pestilentas. O exame, porém, limitava-se aos aspectos visíveis da água, à ausência de impurezas, sua aparência cristalina, e ao seu gosto, se ele não fosse ruim, estava aprovada para o consumo.

Segundo Holanda, no final do século XVIII, nos "lugares mais adiantados, já havia o costume de se quinar as águas transportadas durante as expedições e leválas em grande cabaças ou borrachas de couro", ${ }^{220}$ provavelmente essa tenha sido a primeira tentativa de se tratar a água consumida nos sertões de São Paulo. ${ }^{221}$

O critério de pureza da água tornou-se mais complexo, quantitativo e rígido, à medida que os princípios científicos das doenças nela contidas, foram sendo elaborados, ao mesmo tempo que os processos industriais de seu tratamento se modernizaram, e os levantamentos estatísticos se tornaram mais refinados.

Essas modificações foram lentas, e ao longo dos séculos, através de 4.000 anos de história, em diversos países encontraram-se técnicas para a melhoria da

\footnotetext{
${ }^{219}$ WOLMAN, Abel. Havia regras sobre Água Pura há 4.000 anos atrás. In Revista D.A.E., ano XX, no 23, São Paulo, 1958, p.93.

${ }^{220}$ HOLANDA, Sérgio Buarque, de. Caminhos e Fronteiras. Cia. Das Letras, São Paulo, 1994, p.42.

${ }^{221}$ Quinina, pó branco, inodoro e de sabor amargo, extraído da casca da quina, planta originária do Peru, aplicada no tratamento da malária e também capaz de reduzir o pH da água tornando-a própria para o consumo.
} 
qualidade da água ressaltando-se, todavia, a partir do século XIX os trabalhos de renomados cientistas europeus entre os quais se incluem Puech e Chabal, que construíram na França em 1899, um filtro, para tratar do abastecimento de água da cidade de Paris, que consistia em uma série de filtrações em cascatas, para corrigir a turbidez das águas superficiais.

No sistema de tratamento Puech-Chabal, a água fluía através de filtros baixos para a retenção dos materiais mais grosseiros, evoluindo para um chamado préfiltro, antes de ser tratada por um filtro final. As cascatas eram usadas para aerar a água $^{222}$, entre os diferentes estágios de filtração. A quantidade do material filtrado diminuía sucessivamente, e o tempo da filtração também ficava reduzido de filtro para filtro. Usado largamente na Europa, foi também introduzido no Brasil.

Na Europa e nos Estados Unidos, os séculos XIX e XX marcaram o grande despertar sanitarista, tanto na compreensão da ampla co-relação existente entre a poluição da água e a disseminação das enfermidades, quanto no desenvolvimento, em larga escala, de processos econômicos eficientes utilizados em sua purificação, sendo a Inglaterra e a Escócia, os países pioneiros nos processos de cloração e filtração, ampliados e aperfeiçoados por técnicos norte-americanos, entre 1880 e 1900, principalmente no que dizia respeito, aos filtros lentos de areia, como também, à criação de equipamentos de grande capacidade, os filtros rápidos, para que a filtragem e a cloração se processassem de maneira mais ágil, sem contudo perder sua eficácia.

Nas primeiras décadas do século $X X$, impulso sem precedentes na história da evolução do tratamento da água, foi dado por inúmeros técnicos e cientistas, que se identificaram com companhias particulares de fabricantes de filtros e acessórios, contribuindo dessa forma, para aprimorar o método de coagulação da água, e o aperfeiçoamento de aparelhos destinados à sua cloração de maneira dosada e eficaz.

\subsection{1 Águas turvas}

São Paulo no final do século XIX perdia sua imagem de inocência, e transformava-se a olhos vistos, em uma cidade doente e perigosa. As condições

\footnotetext{
${ }^{222}$ Saturá-la de oxigênio, para a remoção de gases nela dissolvidos como os, sulfídrico e carbônico.
} 
higiênicas da Paulicéia não eram mesmo boas. Ruas sujas, domicílios insalubres, cortiços super povoados e a ausência de um sistema bem implantado de águas e esgotos, que resultavam na proliferação de moléstias: varíola, febres tifóide e amarela, e cólera. O círculo vicioso da miséria e da doença desafiava as autoridades constituídas, e nesse quadro desolador, com graves surtos epidemiológicos, a República vem encontrar São Paulo.

Em $1891,{ }^{223}$ no contexto da reorganização dos espaços destinados aos cuidados com a saúde pública, e à higiene, descentralizados pelo governo federal republicano, foi criada a Inspetoria Geral da Higiene do Estado de São Paulo, com mecanismos destinados ao saneamento do meio, e combate às doenças transmissíveis: o Instituto Vacinogênico, o Laboratório Farmacêutico e de Análises Químicas, e o Bacteriológico.

No ano seguinte, em 1892, essa Inspetoria foi transformada no Serviço Sanitário do Estado, e regulamentado no mesmo ano pela Lei $n^{\circ} 43^{224}$, e a ele foram acrescentados um Serviço Geral de Desinfecção, e uma seção de Estatística Demógrafo-Sanitária.

Constituía-se, principalmente, no policiamento das condições sanitárias das vilas e cidades, das casas coletivas, ou chamadas genericamente na lei, de "habitações de classes pobres", os cortiços, hospícios, asilos, oficinas, como foco de transmissão de doenças, e, em seu combate eram empregados, desinfecções, isolamentos, vacinação, a regulamentação do exercício da profissão de médicos e de farmacêuticos, a fiscalização de alimentos e outros.

O Serviço Geral de Desinfecções, acrescentado em 1893, destinava-se a executar a higiene profilática agressiva: o isolamento domiciliar dos portadores de moléstias transmissíveis, a desinfecção de casas, veículos e objetos de uso pessoal e médico, a remoção de doentes e cadáveres.

As desinfecções, coordenadas por esse Serviço, eram o exemplo mais expressivo do momento de transição em que vivia o conhecimento científico, ainda com os ecos da teoria miasmática, entendendo-se que as doenças seriam transmitidas por miasmas, surgidos da decomposição de matéria orgânica animal e

\footnotetext{
${ }^{223}$ São Paulo, Lei e Decretos. Lei no 120 de 28 de outubro de 1891, cria a Inspectoria Geral de Higiene do Estado e dá outras providências. Typographia do Diário Official, São Paulo, 1891.

${ }^{224}$ São Paulo, Leis e Decretos. Lei no 43, de 18 de julho de 1892, regulamenta a criação do Serviço Sanitário do Estado de São Paulo, e dá outras providências. Typographia do Diario Official, São Paulo, 1892.
} 
vegetal, e de tudo que estava parado ou estagnado, como o ar, a água, os dejetos, o lixo, e os próprios homens, considerados vetores de doenças; portanto, esses vapores ou miasmas, seriam os causadores das epidemias.

Surgiu, desse contexto, como já se disse, a teoria miasmática. A publicação, em 1790, do folheto La miseria del pueblo, madre de enfermedades pelo médico J. P. Frank é indicada por Urteaga, como o arco de uma nova abordagem aos problemas de saúde coletiva, dando origem ao que ele denominou de "Teoría social de la enfermedad". 225

As precárias condições de vida da população pós-Revolução Industrial, fez consolidar essa outra corrente de pensamento, que coexistiu, no meio médico, com a teoria miasmática, a qual identificava a doença como um fenômeno social.

Embora esse conceito estivesse em declínio desde 1870, ele ainda permanecia como explicação de certas moléstias, principalmente aquelas cuja forma de transmissão se ignorava, como por exemplo, a febre amarela. Se as desinfecções estavam mais próximas da concepção miasmática, o mesmo não ocorria com a política do Instituto Bacteriológico, criado em 1893, e sucessor do Laboratório de Bacteriologia do Estado de São Paulo, ${ }^{226}$ que adotava a teoria microbiana.

O governo brasileiro, solicitou, então, ao bacteriologista francês Louis Pasteur (1822-1895), a indicação de um nome de sua equipe para dirigir a instituição. Foi designado o colaborador do Instituto Pasteur, Félix Alexandre Le Dantec, doutor em Ciências Naturais, que elaborou um programa para o Laboratório encarregado de estudar a febre amarela no Brasil: a criação de cursos para capacitação de pessoal, um de técnica em microbiologia, de 40 aulas, e outro teórico, de biologia geral, que trataria entre outros assuntos de fermentação, moléstias microbianas, vacinação e imunização. ${ }^{227}$

\footnotetext{
${ }^{225}$ URTEAGA, Luiz. Miseria, miasmas y microbios. Las topografias medicas y el estudio del medio ambiente en el siglo XIX. Barcelona: Revista Geo Critica, n. 29, 1980, p.35.

${ }^{225}$ Atual Instituto Adolfo Lutz desde 1940. ${ }^{225}$ São Paulo, Leis e Decretos. Lei no 43, de 18 de julho de 1892, regulamenta a criação do Serviço Sanitário do Estado de São Paulo, e dá outras providências. Typographia do Diario Official, São Paulo, 1892.

${ }^{225}$ URTEAGA, Luiz. Miseria, miasmas y microbios. Las topografias medicas y el estudio del medio ambiente en el siglo XIX. Barcelona:

${ }^{226}$ Atual Instituto Adolfo Lutz, desde 1940

${ }^{9}$ LEMOS, F.C. Contribuição à História do Instituto Bacteriológico, 1892-1940. Revista do Instituto Adolfo Lutz. São Paulo, vol.14, 1954, pp 5-161.

${ }^{10}$ Decreto no 233, de 2 de março de 1894, estabelece o Código Sanitário do Estado, e dá outras providências. Typographia do Diario Official. São Paulo, 1893.
} 
A polaridade miasma-micróbio, estava presente na política e na estrutura da saúde pública, caracterizando o momento de transição em que a velha concepção não havia sido ainda inteiramente abandonada, e a nova, de todo aceita.

Um ano depois, dando continuidade à política higienista, foi criado o primeiro Código Sanitário de São Paulo $^{228}$, que reuniu as normas de saúde pública, e as práticas sanitárias no combate às epidemias e às moléstias infecto-contagiosas, apoiando-se em intervenções que resultaram nas reformas urbanas do final do século XIX, e início do XX, também de caráter sanitário, e que envolveram a construção de rede de água encanada e de esgotos, a higiene das habitações, as desinfecções dos espaços públicos e privados, e a segmentação do espaço urbano em funções especializadas.

Foram criados quatro grandes laboratórios, que teriam importante papel no desenvolvimento da política de saúde: de Análises Químicas, para acompanhar a qualidade sanitária dos gêneros alimentícios comercializados no Estado, o de Bacteriologia, para o estudo da etiologia das epidemias, endemias, e epizootias ${ }^{229}$ mais freqüentes, ao qual estava afeta a análise da qualidade da água consumida em São Paulo, o Instituto Vacinogênico para os trabalhos de cultura da vacina animal contra a varíola, e o Farmacêutico, que deveria suprir a demanda por medicamentos, das instituições públicas de saúde.

O laboratório de Bacteriologia, transformado em Instituto Bacteriológico do Estado de São Paulo em 1893, tendo à sua frente Adolfo Lutz, destacou-se pelos estudos sobre difteria e febre tifóide. No relatório anual de atividades, o cientista, em que pesem as divergências com os médicos paulistas, revelara a sua convicção de que os casos das chamadas "febres paulistas" deveriam ser diagnosticados como sendo de febre tifóide. Lutz, tornou pública sua avaliação sobre a doença, antes de comprovar o diagnóstico em laboratório, o que somente ocorreu no ano de 1897.

\footnotetext{
${ }^{229}$ O caráter distintivo das Epidemias está em sua manifestação coletiva e singular; "coletiva" enquanto fenômeno que atinge grupos de indivíduos provocando alterações em sua saúde e no seu dia a dia e "singular" enquanto ocorrência única na unidade de tempo e espaço em que ocorre. Convencionou-se no Brasil designar determinadas doenças, a maioria delas parasitárias ou transmitidas por vetor, como "Endemias", "grandes endemias", ou "endemias rurais". Essas doenças foram e são, a malária, a febre amarela, a esquistossomose, as leishmanioses, as filarioses, a peste, a doença de Chagas, além do tracoma, da bouba, do bócio endêmico e de algumas helmintíases intestinais, principalmente a ancilostomíase. Epizootias, doenças que atacam numerosos animais no mesmo lugar, e ao mesmo tempo, contagiosas ou não, e que eventualmente podem ser transmitidas ao homem. In Cadernos de Saúde Pública. Vol. 3 № 1 Rio de Janeiro/Março de 1987, p.17.
} 
Em 1896, foi também criada a Seção de Estatística Demógrafo-Sanitária, responsável pela sistematização de dados estatísticos sobre as condições de saúde da população, revelando a inequívoca intenção de transformar a saúde pública baseada em conhecimentos empíricos, em tentativas e erros, em uma saúde pública fundamentada em conhecimentos especializados, na realização de diagnósticos, definição de profilaxia, e de procedimentos terapêuticos. Com o auxílio de estudos microscópicos de parasitologia, sorologia e outros, elucidava-se a natureza das doenças e sua forma de cura, ou seja a revolução pasteuriana, que diagnosticava e curava doenças, suprindo a incapacidade da teoria miasmática de fazê-lo.

A Capital paulista apresentava coeficientes de óbitos por doenças infectocontagiosas, superiores aos verificados no Estado de São Paulo, com exceção de alguns anos, nos quais as cidades do interior sofreram epidemias de febre amarela. Durante o período de 1894 a 1929, São Paulo apresentou participação nos óbitos por moléstias infecto-contagiosas, superior à de Santos.

A administração municipal paulistana era responsável, em termos de higiene e saúde públicas, por sanear as várzeas, fiscalizar o cumprimento do contrato de concessão dos serviços de limpeza pública, de água e esgoto e outros. Nas duas primeiras décadas do século $X X$, as autoridades sanitárias orientaram-se no combate às epidemias, e às moléstias infecto-contagiosas por meio de uma reforma urbana de caráter sanitário.

Faziam parte também, de sua área de atuação, as desinfecções dos espaços públicos e privados, o isolamento dos doentes, e por fim, a vacinação contra varíola, raiva, peste, mordida de cobras, aranhas e escorpiões, no momento em que explodia o debate sobre saúde pública - o higienismo - assentado em princípios da bacteriologia e sobretudo da microbiologia das águas, graças, principalmente, aos trabalhos de Pasteur e Koch, que foram um estímulo que impulsionou a busca de bactérias nas mais diversas águas, comprovando-se que sua flora bacteriana não é uniforme, mas oferece uma extraordinária variedade como acontece com a da terra. 
La microbiologia de las aguas estudia la estructura y la vida de los microorganismos de los manantiales, rios, lagos y mares, así como su función en el ciclo material de água y los sedimentos. Trata también de las relaciones de esos microorganismos com el resto de animales y plantas que tienen su hábitat em dichos médios, así como del comportamiento de las espécies terrestres em los biótopos acuáticos" ${ }^{\prime 30}$ (RHEINHEIMER, 1987)

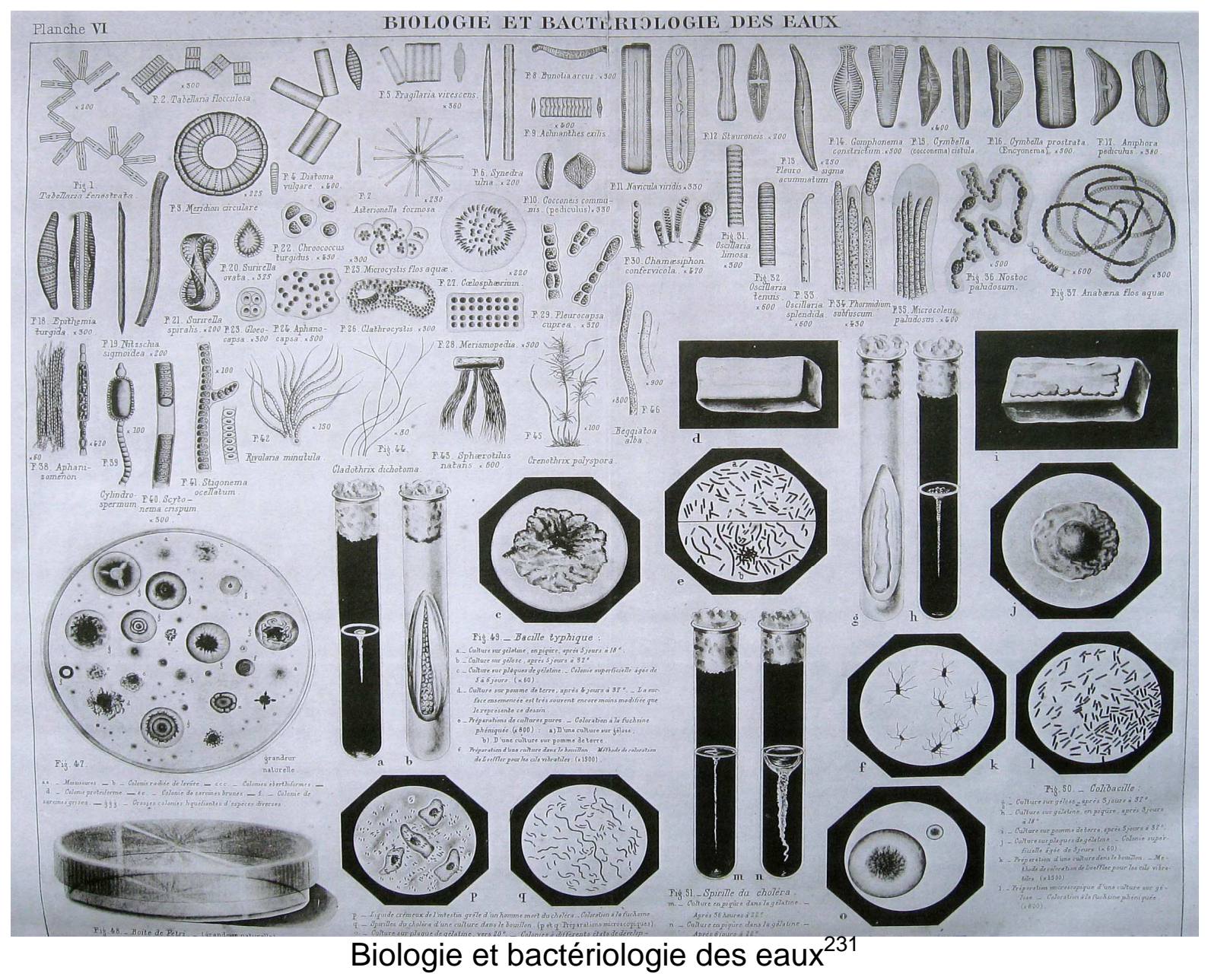

A microbiologia, ciência que busca especificamente estudar a formação, o desenvolvimento, e as funções dos seres microscópicos, ao contrário do que se afirma convencionalmente, não se derivou instantaneamente das "descobertas de Pasteur", mas foi consolidada aos poucos na história da medicina.

Antes da invenção do microscópio, já haviam sido descobertas bactérias na água, junto a outros microorganismos. Van Leeuwenhoek, não se limitou a

\footnotetext{
${ }^{230} 1$-RHEINHEIMER, Gherhardt., Mikrobiologie der Gewässer, Ed. Veb G.F.V.Jena. De la edición em lengua española Ed. Acribia. Zaragoza, 1987, p.1.

${ }^{231}$ DEBAUVE ,A. Imbeaux, Ed. Distributions D'Eau. Assainissement Des Villes. Vve.CH.Dunod, Éditeur, Paris, 1905, Planche VI.
} 
representar as imagens de cocos, bacilos e espirilos em 1683, como também estudou sua movimentação em uma gota d'água. ${ }^{232}$

Porém, a microbiologia das águas não progrediu até o século XIX, quando os diversos estudos, análises e procedimentos, como a identificação e o isolamento de microorganismos patogênicos e sua manipulação, provocaram uma revolução na sistemática de combate às doenças infecciosas e suas formas de contágio, chegando-se aos métodos preventivos das vacinas, e à abertura terapêutica da soroterapia.

Desde a origem da epidemiologia, entretanto, admite-se que o espaço geográfico mantém com os fatos da saúde relações determinantes. Hipócrates, em seu: "Ares, águas e lugares", discutia a interação Homem e Natureza, como imperativo para uma vida sadia, atribuindo a fatores climáticos, geográficos e mesmo astronômicos, determinados perfis de adoecimento nos indivíduos. Seu texto, dirigese a quem quer que pretenda perseguir adequadamente, a ciência da medicina, descrevendo uma espécie de roteiro de observações: as estações do ano, os ventos, as propriedades da água, a análise de sua proveniência, qualidade e quantidade. $^{233}$

Muitas de suas preocupações, ainda são atuais, quando os gestores públicos de controle de endemias, estudam as causas e maneiras de minimizar e erradicar alguns agravos à saúde coletiva: o tipo de solo, e o modo de vida das pessoas, são citados de uma forma que poderia parecer, em nosso tempo, a sistematização do senso comum acerca das doenças, assim como os elucidativos mapas de John Snow, que permitiram demonstrar a ligação inequívoca entre a epidemia de cólera e a distribuição de água. ${ }^{234}$

O miasma, como agente deletério deixa de ser, portanto, considerado a causa principal da origem das doenças, embora tivesse fornecido a base científica para as intervenções necessárias ao novo papel da cidade, no desenvolvimento econômico. No final do século XIX, e até a terceira década do século seguinte, a ventilação e a

\footnotetext{
${ }^{232}$ RHEINHEIMER, Gerhard. Mikrobiologie der Gewasser. Edição em língua espanhola de VEB, Gustav F.V.Jena. Editora Acribia S/A. Saragoza-Espanha, 1987, p.13.

${ }^{233}$ HIPPOCRATES. Airs, Waters and Places, in BUCK, C. et al (orgs.) - The Challenge of Epidemiology - Issues and Selected Readings. Washington D.C. Pan American Health Organization, Scientific Publication no 505, 1988 p.18-9.

${ }^{234}$ SNOW, John. Sobre a Maneira da transmissão da cólera. $2^{\underline{a}}$ Ed. Imprensa São Paulo, Hucitec 1990. São Paulo.
} 
insolação - nem sempre numa perspectiva conjunta - estarão fundamentalmente relacionados com a salubridade

A partir de 1890, para resolver os problemas de urbanização e conseqüente infra-estrutura, e livrar São Paulo das endemias de cólera, (cólera-morbo), peste bubônica, e as febres, tifóide e amarela, que reinavam na capital e eram responsáveis pela morte de quase uma pessoa por dia, nos bairros mais pobres da cidade:

(...) executaram-se vastas e custosas obras de saneamento, sobretudo na várzea do Tamanduateí, canalizaram-se os rios e ribeirões da cidade; garantiu-se para a população, melhor e maior quantidade de água potável; rasgaram-se novas ruas e avenidas, ajardinaram-se as praças e pavimentaram- se da melhor maneira possível, as ruas principais da cidade (...). ${ }^{235}$ (PETRONE, 121)

No esforço de torná-la mais bonita e aprazível, e principalmente debelar as chamadas "febres paulistas" ou de "mau caráter"236, identificadas, como já se disse, por Adolfo Lutz, como febres tifóide, provocadas pelo salmonella typhi, bacilo isolado pelo médico e bacteriologista alemão Karl Joseph Eberth, em 1880.

Esse tipo de enfermidade, grassava nos bairros mais pobres e sujos de São Paulo, cuja "população foi proibida de passear e fazer piqueniques em locais próximos aos mananciais, a fim de evitar contaminação, porque já se constatara que a água do abastecimento, ainda não estava contaminada". ${ }^{237}$

A surpreendente urbanização de que fala Pierre Monbeig ${ }^{238}$, teve como causa um "boom" populacional impressionante, mais de mil novas casas eram construídas por ano, alterando de forma irreversível o meio natural, transformando-o em um ambiente artificial, surgindo, por conseqüência, a respeito da água, acalorados debates sobre as fontes mais adequadas para obtê-la, e sobre sua qualidade, para que pudesse ser servida de forma saudável, aos cidadãos paulistanos.

\footnotetext{
${ }^{235}$ PETRONE Pasquale. São Paulo no século $X X$. In A cidade de São Paulo-Estudos de geografia urbana. v. II, s/d.Cia. Ed. Nacional, São Paulo, p.121.

${ }^{236}$ Relatório da Secretaria da Cultura, 1893, p.26.

${ }^{237}$ RIBEIRO, Maria Alice Rosa. História sem fim. Inventário da Saúde Pública-São Paulo - 1880-1930 UNESP, São Paulo, 1993, p.37.

${ }^{238}$ MONBEIG, P. Aspectos geográficos do crescimento de São Paulo.In "O Estado de São Paulo, 2501-1954, SP, p.28.
} 
Essa questão dividia opiniões, por um lado estavam os defensores do ideal de se captarem águas "de cabeceiras em bacias vestidas de florestas" conforme determinava o código sanitário de 1894, em seu capítulo XV:

Abastecimento de água:

"Artigo 311. A agua destinada aos usos domésticos deverá ser potável e inteiramente insuspeita de polluição.

Artigo 312. Provirá de manancial sempre que fôr possível com origem na serra.

Artigo 313. As mattas existentes nas cabeceiras deverão ser conservadas do melhor modo possível.

Artigo 315. Deve ser prohibido in limine o systema de açudes para captação de manciaes, que têm de fornecer agua potavel para os usos hygienicos e domésticos.

Artigo 322. Além disso deverão ser as aguas sujeitas ás analyses chimica, hydrotimetrica e micrographica”. 239

Do outro lado, estavam aqueles que combatiam o mito da pureza natural das águas, argumentando que nascentes isoladas eram raras e que bastava um simples vetor contaminando um manancial, para originar epidemias de tifo, como ocorrera no final do século XIX e começo do XX, em várias cidades da Europa e dos Estados Unidos, que se abasteciam de águas de nascentes supostamente puras, porém causadoras de um grande número de óbitos.

Em razão dessa assertiva, diziam: todas as águas são perigosas independentes da ausência de contaminação dos mananciais de sua procedência, e somente sua análise com o tratamento químico adequado, poderia assegurar água de qualidade à população paulistana.

${ }^{239}$ São Paulo, Leis e Decretros. Decreto no 233, de 2 de março de 1894. Estabelece o Código Sanitário de São Paulo, Diário Oficial do Estado de São Paulo, p. 18. 
Os avanços do conhecimento científico, estabelecendo um nexo causal entre os microorganismos presentes na água potável, hábitos de higiene, tratamento de esgotos e a propagação das doenças, foi o propulsor de uma atuação conjunta entre médicos, engenheiros e poder público no sentido de melhorar as condições de vida da população paulistana nos primórdios do século $X X$.

Para controlar a qualidade da água, as análises bioquímicas de sua potabilidade, começaram a ser feitas sistematicamente, assim como houve um incentivo por parte do governo, para os projetos de fabricação de equipamentos, e aparelhos sanitários, ao mesmo tempo em que a rede pública de saneamento expandia-se, atingindo dois objetivos: debelar as epidemias que assolavam a cidade, e atrair maior número de imigrantes, garantindo, dessa forma, o êxito dos processos de expansão cafeeira, urbanística e industrial. A combinação, portanto, dos interesses da cafeicultura, expansão ferroviária, imigração, e febre amarela definiu os rumos da ação sanitária promovida pelas oligarquias no poder nesse período. A organização autoritária do Estado brasileiro, não dava espaço à implantação de ações individuais de assistência à saúde.

O modelo centralizador do primeiro código sanitário do Estado, cujas medidas autoritárias não respeitavam as especificidades locais, foi mantido na reforma de 1906, que o reforçou, ampliando o poder estadual sobre as questões de saúde.

Nesse mesmo ano, foi instalado junto a Repartição de Águas e Esgotos (R.A.E.), o primeiro laboratório de análises químicas, que funcionou normalmente durante todo o exercício, embora sua existência legal tenha ocorrido somente no ano seguinte, com o decreto $n \times 1509^{240}$.

Fundado pelo químico francês, Henri Charles Potel, possuía todos os aparelhos e utensílios necessários para as pesquisas. Era executada uma média de 12 análises químicas por semana, e o exame bacteriológico diário, a partir de fevereiro de 1906, com a coleta de até 10 amostras de águas. No final de 1906 haviam sido feitas 595 investigações sobre a potabilidade, e 90 exames bacteriológicos das águas que abasteciam a cidade.

\footnotetext{
${ }^{240}$ São Paulo, Leis e Decretos. Decreto no 1509, de 4 de setembro de 1907. Cria o Laboratório de Análises da Repartição de Águas e Esgotos de São Paulo, e dá outras providências. Typographia do Diario Official, São Paulo, 1907.
} 
Somos obrigados a tolerar nas águas da cidade de São Paulo, uma quantidade de matérias orgânicas superior à que se tolera na Europa. Deve-se ser mais rigoroso com relação ao cloro e aos nitratos, pois estes constituem, sempre, indícios de infiltração de águas residuárias". ${ }^{241}$ (BRANCO, 1964)

Não era essa, porém, a opinião das autoridades de então, segundo elas "as aguas aproveitadas no abastecimento de São Paulo, sendo na maioria de boa qualidade, carecem de filtração para evitar as pulluições observadas na epocha das chuvas". 242

Mas o grande problema que afligia essas autoridades sanitárias, era que tipo de filtros empregar, para se conseguir o melhoramento das características físicas, da composição química, e da qualidade bacteriologica das águas.

A conclusão irrefutável da ciência experimental da época, depois de uma série importante de trabalhos produzidos na Inglaterra, França, Alemanha e Estados Unidos, resumia-se na preferência manifestada pelos filtros lentos de areia, como os mais eficazes. Porém, para as condições do precário serviço de águas de São Paulo, durante os primeiros anos do século XX, a instalação de filtros lentos, além de ser extremamente onerosa, acarretava considerável diminuição de vazão das linhas adutoras, perdendo a água, com isso, a necessária pressão para percorrer o sistema de distribuição e chegar até as caixas d'água espalhadas pela cidade.

Arthur Motta, diretor da R.A.E., em seu relatório de 1906 ao Secretário da Agricultura, à qual esta repartição estava afeta dizia:

"Demais, as aguas de São Paulo, com excepção das do Tieté, não apresentam o grau de impureza accentuado e offerecem a garantia de serem as respectivas bacias desapropriadas."243

O pensamento corrente e unânime da ciência desse começo de século, era a de se proceder a uma filtração lenta, precedida de outra preliminar, os filtros rápidos, aqueles em que a velocidade com que a água atravessava o leito filtrante era elevada, constituíndo-se em uma barreira sanitária importante,

\footnotetext{
${ }^{241}$ BRANCO, S.M. Henri Charles Potel e a Biologia das Águas de São Paulo. In Revista do D.A.E..Editora Diagrama Comunicações Ltda. São Paulo, 1964, p.26.

${ }^{242}$ Relatório da Repartição de Águas e Esgotos de São Paulo, de 1906, apresentado ao Secretario da Agricultura, pelo Diretor. Typographia Brazil de Rothschild \& Co.,São Paulo, 1907, p-16.

${ }^{243}$ Ibidem, 1907, p.16
} 
podendo reter micro organismos patogênicos que resistiam a outros processos de tratamento. $^{244}$

As vantagens da filtração lenta sobre a rápida, eram evidentes: o não emprego de produtos químicos, e de energia elétrica; podia-se obter água de características menos corrosivas, com a filtração lenta, porém a associação de ambas, estava sendo empregada em larga escala na Europa, no sentido de evitar o quanto possível as impurezas da água, antes de admití-las nos filtros de areia, com o intuito de aumentar a velocidade de sua purificação, o que levou o diretor da R.A.E., adotar este meio termo entre os dois tipos: os lentos de areia, e os clarificadores rudimentares, os rápidos.

A boa água deve:

10 Molhar bem a boca e o paladar, acalmar a sede sem a excitar, e não ser pesada no estômago;

$2^{\circ} \quad$ Ferver facilmente sem se turbar, nem fazer espuma, evaporar-se sem deixar resíduo manifesto; arrefecer depressa;

$3^{\circ}$ Coser bem os legumes, sem os tornar rijos, extrahir com facilidade os principios arometicos da plantas sem alterar o sabor;

4ํㅡㄹ Dissolver o sabão com facilidade;

$5^{\circ} \quad$ Amollecer a pelle e laval-a. ${ }^{245}$ (GRIMAUD, 2001)

Vital e mortal, ignorada onde abunda, aguardada com veneração quando sazonal e brutalmente disputada se escassa, a água se tornou procupação atual, privilégio mais retrito e mercadoria que se generaliza. ${ }^{246}$ (MARX, 2004)

É fácil atribuir-lhe muitos qualitativos, porém, a água é indefinível. Fica-se sempre muito aquém de sua complexa e inatingível personalidade, que também pode ser descrita por uma série de parâmetros. Coisa para laboratórios, papilas e olfatos sensíveis, esses parâmetros qualificam a água, seus usos e aplicações: dissolução, capacidade térmica, tensão superficial, capilaridade, $\mathrm{pH}$, dureza, salinidade, turbidez, cor, odor e sabor. Uma análise do padrão de qualidade da água

\footnotetext{
${ }^{244}$ Filtração é o processo que remove as impurezas presentes na água bruta (filtração lenta); na água coagulada ou floculada (filtração rápida direta); ou na água decantada (filtração rápida) pela passagem destas em um meio granular poroso, geralmente constituído em camadas de pedregulho, areia e antracito (comum nos filtros rápidos).

Foi introduzida nos Estados Unidos em 1883, por Hyatts., Jewells, Warren e outros.

${ }^{245}$ GRIMAUD, De Caux, apud AMORIM, Alexandra Agra; PINTO, João Neves in Porto d'agoa. Porto, 2001 , p.125.

${ }^{246}$ MARX, Murillo apud Cidade das águas, KAHTOUNI Saide. Ed.Rima, São Paulo, 2004, Prefácio.
} 
em laboratório considera 33 indicadores físicos, químicos e microbiológicos. Desses, nove compõem o Índice da qualidade das águas, (IQA): oxigênio dissolvido (OD), demanda bioquímica de oxigênio (DQO), coliformes fecais, temperatura da água, $\mathrm{pH}$ da água, nitrogênio total, fósforo total, sólidos totais e turbidez.

As águas doces podem se transformar em amargas, quando transmissoras de uma série de moléstias, por agentes infecciosos e parasitários, trazendo, quando não tratadas, riscos epidemiológicos ao meio urbano.

O urbanismo moderno no Brasil, teve início justamente com os trabalhos de sanitaristas como os engenheiros, Saturnino de Brito e Aarão Reis, nos anos de 1890 e 1900, auge dos surtos epidêmicos, que grassavam nas capitais brasileiras.

Desde Março de 1894, com a lei n² 233, que reorganizou o serviço Sanitário do Estado de São Paulo, somente em 1911, ocorreu a segunda importante mudança do aparelho estadual da saúde pública, durante a gestão de Emílio Ribas à frente da Diretoria deste Serviço.

Este período, caracterizou-se por uma maior autonomia do Município, concedida através do Decreto Estadual $2141^{247}$, quando determinava no artigo $3^{\circ}$ :

"Compete aos municípios:

Realizar os melhoramentos higiénicos essenciais ás localidades como - esgotos, drenagem das águas pluviaes, abastecimento de água potável, enxugo do solo, calçamento, e providencia quanto á irrigação e asseio das vias publicas, praças, logares e logradouros públicos, remoção e destino final do lixo;

Art. 288 - Nenhum prédio construído em localidade provida de água canalizada e rede de esgotos poderá ser habitado senão depois de dotado destes melhoramentos.

Art. 289 - Nas localidades providas de água potável canalizada, os poços serão tolerados unicamente para fins industriaes ou para horticultura e desde que sejam convenientemente protegidos.

Art. 290 - Nas localidades onde não houver água potável canalizada, serão permitidos os poços que tiverem água pura.

${ }^{247}$ São Paulo, Leis e Decretos, Decreto no 2141 de 14 de novembro de 1911, reorganiza o Serviço Sanitário do Estado de São Paulo e dá outras providências. 
Art. 291 - É proibido o despejo de matérias residuaes nos cursos de água dentro ou fora das povoações, salvo em rios de grande vazão, ou depois de feita a depuração dos resíduos.

Art. 292 - Onde não houver rede de esgotos para o afastamento das águas residuaes, compete á Diretoria geral aconselhar o processo mais tolerável.

Art. 422 - poderá ser empregado nos esgotos das cidades, conforme as circunstancias locaes, qualquer dos sistemas - separado, misto ou unitário"

Essa fase, seria caracterizada também, pela consolidação do modelo "campanhista-policial", segundo Merhy $^{248}$, e que orientou o conjunto das práticas sanitárias, introduzidas nas primeiras duas décadas da República. A bacteriologia, foi a musa inspiradora dos sanitaristas da época, gerando intervenções baseadas na ação da polícia sanitária e nas campanhas de combate às doenças infectocontagiosas, que assumiam caráter epidêmico, em regiões de grande importância para o processo econômico e político da época.

Surge a figura do Inspetor Sanitário, ${ }^{249}$ responsável pela prática do policiamento e da vigilância sanitária, a quem cabia entre os diversos serviços de saúde pública, a fiscalização da qualidade da água e do esgoto, colhendo amostras e exercendo seu poder de polícia, fazendo cumprir o Código Sanitário, por meio da aplicação de intimações e multas.

Em geral, trabalhos sobre as políticas de saúde pública no Etado de São Paulo, não levavam em conta as relações entre a política sanitária paulista, e os problemas na área da saúde, enfrentados pelo governo federal, e demais estados brasileiros, as análises ficavam restritas ao contexto oligárquico; a políticas de saúde são explicadas, basicamente, como uma transformação necessária à expansão da produção cafeeira.

Telarolli Junior ${ }^{250}$, aponta a política estadual de importação de trabalhadores estrangeiros, como uma das principais responsáveis pelo desenvolvimento dos

\footnotetext{
${ }^{248}$ MERHY, Emerson Elias.Capitalismo e a saúde pública: a emergência das práticas sanitárias no Estado de São Paulo. Ed.Papirus, Campinas, 1987, p.52.

${ }^{249}$ São Paulo, Leis e Decretos, Decreto 2141 de novembro de 1911, que reorganiza o Serviço Sanitário do Estado.Título II art. 8‥

${ }^{250}$ TELAROLLI, Junior, Rodolfo. Poder e Saúde. A República, a febre amarela e a formação dos serviços sanitários em São Paulo. Tese de Doutorado (Doutorado em Saúde Coletiva) - Universidade Estadual de Campinas, 1993.
} 
serviços sanitários em São Paulo. A proteção aos imigrantes era, segundo o autor, fundamental para o desenvolvimento do setor cafeeiro.

A reforma de 1911, teve por objetivo, portanto, tratar de forma mais enfática da solução dos problemas da urbanização desordenada na Capital, como também das áreas de atuação do Estado e do Município, que, entre outras atribuições, deviam fazer cumprir as leis sanitárias, principalmente no que dizia respeito ao melhoramento dos serviços de água e esgoto; entretanto, a responsabilidade com o abastecimento de água recaiu, sobre outra esfera de poder, a estadual, através da Repartição de Águas e Esgotos (R.A.E.), ligada à Secretaria da Agricultura.

A previsão de que a cidade atingiria mais de três milhões de habitantes num futuro próximo, suscitava acirradas discussões sobre as fontes de captação, e distribuição de água, atendendo-se aos parâmetros do Código Sanitário sobre as zonas edificáveis, e a capacidade de abastecimento dos mananciais, que seriam aduzidos de acordo com suas normas, o que sem dúvida, diminuiria a incidência da febre tifóide, de perturbações gastrointestinais e de outras moléstias, reduzindo sensivelmente a mortalidade infantil.

Somente os mananciais que se encontravam a um raio de 100 quilômetros da cidade, portanto, apenas os rios Claro e Cotia, se enquadravam no mito vigente do século XIX, de que as águas captadas nas nascentes e cabeceiras, eram naturalmente puras pela ausência de moradores em suas bacias, uma vez que, de acordo com o artigo 314 do código sanitário de 1894:

"Deverão ser abslutamente prohibidas habitações acima das represas ou tomadas de água." 251

A distância de 20 a 50 quilômetros dos reservatórios ou rios, escolhida como ideal pelos sanitaristas, entre a aglomeração urbana e os mananciais, no começo do século $X X$, é diminuída pelo aumento populacional significativo nos primeiros anos desse século. Segundo a visão da época, nesse período, as boas qualidades de uma água potável eram as seguintes:

\footnotetext{
${ }^{251}$ São Paulo, Leis e Decretos. Decreto no 233, de 2 de março de 1894.O Presidente do Estado para a execução do artigo $3^{\circ}$ da Lei o 240 de 4 de Setembro de 1893, estabelece o Código Sanitário de São Paulo, e dá outras providências. Diário Oficial do Estado de São Paulo, Cap.XV Abastecimento de Água. p.18.
} 
$1^{1}$, ausencia de mistura de toda materia animal ou vegetal, principalmente de toda materia em estado de decomposição;

$2^{\mathrm{a}}$, mistura de ar puro;

$3^{\text {a }}$, doçura;

$4^{a}$, ausencia de toda materia terrosa ou mineral;

$5^{a}$, frescura ou temperatura média, que não seja muito elevada no estio, nem excessivamente baixa no inverno;

6 ${ }^{\text {a }}$ limpidez. ${ }^{252}$ (OLIVEIRA, 1903)

As propriedades físicas das águas, as higiênicas e a conseqüente remoção de bactérias, protozoários, vírus e outros microorganismos, e as estéticas, correção da cor, sabor, odor, e transparência, foram motivos de preocupação e atenção especial por parte de estudiosos do assunto, principalmente em finais do século XIX e no decorrer do $\mathrm{XX}$, desenvolvendo-se inúmeros processos de tratamento físico, químico e biológico, com métodos de análises, e aparelhos purificadores de toda espécie, para a classificação dos cheiros, e medição das cores, turbidez e limpidez.

Segundo Belgrand ${ }^{253}$, "a água pode ser considerada salubre quando as populações que d'ella fazem uso desde muito tempo são sadias, vigorosas e sem enfermidades especiaes". ${ }^{254}$

De acordo com o historiador Affonso A. de Freitas, o primeiro administrador a se preocupar com a potabilidade das águas da cidade, foi o Capitão-General Bernardo José de Lorena, Governador da Capitania de São Paulo, no período de 1788 a 1797, famoso pela grande obra que realizou em sua administração, a primeira estrada pavimentada para a descida da Serra do Mar, que ficou conhecida como a Calçada do Lorena.

Em 1791, o Governador Lorena, determinou ao químico Bento Sanches d'Orta, que procedesse à análise de algumas águas das fontes existentes na cidade, e do rio Tamanduateí, onde a população costumava se abastecer, e cujos resultados foram os seguintes:

\footnotetext{
${ }^{252}$ OLIVEIRA, J. E. da Silva. Hydraulica. Lições dadas na Escola Militar do Brazil. Editora Imprensa Nacional, Rio de Janeiro, 1903, p.250.

${ }^{253}$ Os primeiros estudos se iniciaram com o engenheiro francês Eugène Belgrand, auxiliar de Haussman, responsável pelas remodelações que ocorreram na cidade de Paris, sob a iniciativa de Napoleão III, e que o transformaram em uma referência na história do urbanismo das cidades. Belgrand, foi o encarregado de aproveitar as obras que estavam sendo realizadas em Paris, para construir em toda a capital, uma dupla rede de canalizações subterrâneas em alvenaria, de grandes dimensões, por onde passariam as tubulações das águas potáveis e servidas, os famosos esgotos de Paris).

${ }^{254}$ In OLIVEIRA, J. E. da Silva. Hydraulica. Lições dadas na Escola Militar do Brazil. Editora Imprensa Nacional, Rio de Janeiro, 1903, p.251.
} 
“A do Lorena. É ferrea e fria, com sal neutro, a base terrea argilosa. Pelas referidas qualidades póde-se usar della sem receio de molestia alguma: e igualmente é boa para branquear panno de linho e algodão.

A da fonte do Gayo. É muitíssimo ferrea e fria, acida vitriolica, a base térrea calcarea, de óca, com algumas particulas arsenicaes ainda que tênues e summamente saturada de gaz-mefitico. Qualidades perniciosissimas á economia animal, e bem capazes de produzirem molestias graves.

A Agua do rio Tamanduatehy. É pouco ferrea, acida com sua base de terra argilosa e vegetal, o que compõem uma mistura lodosa pesada. Cheia de ar fixo e inflammavel, de onde procede a má côr e máo gosto dessa agua. O seu uso não sería muito pernicioso; mas, para branquear panno de linho ou algodão, não é bôa. ${ }^{255}$ (AFFONSO, 1929)

Segundo o mesmo autor, de todas as águas pesquisadas, a da fonte de Santa Luzia, localizada na atual rua de Santa Luzia, entre as ruas Conselheiro Furtado, e Dr. Tomaz de Lima, era "fria, acida a base de terra argilosa, em pequena quantidade e livre de toda selenites e ar fixo". ${ }^{256}$ Considerada como excelente para o consumo, a de melhor qualidade das que haviam sido até então analisadas.

Eram assim expressos os dados de nossas águas, na mesma época em que Lavoisier, Bertholet, e outros, conceberam um sistema de nomenclatura química que é a base do sistema moderno de denominação dos compostos químicos.

Após o governo de Lorena, não mais se cogitou de saber a qualidade das águas ingeridas pela população paulistana; a própria Companhia Cantareira de Águas e Esgotos, somente realizaria uma análise feita em 1864, pelos farmacêuticos Schaumann e Thiele, da Botica Veado D'Ouro.

Alguns anos mais tarde, em 1894, a R.A.E., através de José Pereira Rebouças, solicitava uma análise dos reservatórios situados na Serra da Cantareira, feita no Instituto Agronômico de Campinas, por Henri C .Potel, que mais tarde seria o fundador do Laboratório de Análises Clínicas da mesma repartição.

Passados vinte e cinco anos, em 1919, as análises realizadas pelo Laboratório do Serviço Sanitário de São Paulo, condenaram as águas do rio

\footnotetext{
${ }^{255}$ AFFONSO A. de Freitas. Diccionario Historico, Topographico, Ethonographico Illustrado do Município de São Paulo. Tomo I. Editora Graphica Paulista.São Paulo, 1929, pp.138/139.

${ }^{256}$ Ibidem
} 
Tamanduateí, e dessas fontes, incluindo a de Santa Luzia, famosa pela decantada pureza, "como fortemente poluídas, principalmente em função da reação pelo violeta de metila e, certamente, pelos seus elevados teores de cloretos, "amoníaco livre e "anidrido azótico"... 257

Um sistema de abastecimento de água, é a solução coletiva para o suprimento de uma comunidade. Caracterizado por um conjunto de obras, equipamentos e serviços, através dos quais as águas são regularizadas, captadas, elevadas, aduzidas, purificadas, controladas, armazenadas e distribuídas, ganhando um valor, em decorrência de todas essas obras, instalações e operações, que devem ser mantidas para seu correto estabelecimento, e sua extensão a uma parcela cada vez maior da população.

Esses serviços, contínuos e permanentes, análogos ao de uma indústria, exigem a aplicação de capitais, o consumo de materiais, o dispêndio de energia e o trabalho dedicado de um grande número de pessoas.

É o que ocorre especialmente com o tratamento de água, que tem por objetivo condicionar as características da água bruta, como é encontrada na natureza, a fim de atender à qualidade necessária a um determinado uso; quanto maior for o número de poluentes presentes, mais demorado e custoso se torna o tratamento. O processo convencional utilizado, na grande maioria das vezes, é feito pelas estações de tratamento de água dos mananciais.

A água própria para o consumo, ou água potável, deve obedecer a padrões de qualidade organoléptica, ou seja, não possuir odor e sabor objetáveis; quanto ao aspecto físico, deve ser agradável, não ter cor e turbidez acima dos padrões de potabilidade, bem como não deve conter substâncias nocivas ou tóxicas acima dos limites de tolerância para o homem, e não conter germes patogênicos.

Em razão desses fatores, a água captada deve passar por tratamentos que objetivam não somente eliminar as substâncias nocivas e microorganismos patogênicos prejudiciais à saúde humana, como também garantir seu aspecto físico agradável, sem cor, cheiro ou sabor, cristalina e sem turbidez.

\footnotetext{
${ }^{257}$ BRANCO, Samuel Murgel et all. Episódios Pitorescos selecionados da História do Saneamento em São Paulo. In Revista do Departamento de Águas e Esgotos de São Paulo (DAE), São Paulo, no 147, vol. 46, 1986, p.353.
} 
O Governo Federal criou, através do Decreto $n^{\circ}$ 24.643, o "Código das Águas", ${ }^{258}$ que precedeu em 15 anos a abertura do primeiro curso de pós-graduação em engenharia sanitária no Brasil, na Faculdade de Higiene e Saúde Pública de São Paulo, em 1949. A iniciativa contou com o apoio dos Estados Unidos, que exerceu forte influência na matriz sanitária da engenharia nacional. A implantação desenfreada de estações de tratamento de água do tipo convencional, a partir dos anos 50 , composta das unidades de coagulação, floculação, sedimentação, filtração rápida, desinfecção, fluoretação e correção do $\mathrm{pH}$, é um exemplo dessa afirmativa.

A partir da promulgação da Portaria ํㅡ 36, do Ministério da Saúde, foram estabelecidos novos padrões de potabilidade da água, os quais passaram a vigorar a 23 de Janeiro de $1992^{259}$.

A Portaria 518, estabelece que "as coletas devem ter distribuição uniforme ao longo do período e representatividade do sistema de distribuição, combinando critérios de abrangência espacial e pontos estratégicos, entendidos como aqueles próximos a grande circulação de pessoas ou edifícios, que alberguem grupos populacionais de risco (hospitais, creches e asilos), e aqueles localizados em trechos vulneráveis do sistema de distribuição, como pontas de rede". 260

O processo de tratamento de águas convencional utilizado, na grande maioria das vezes pelas estações de tratamento, adota a seguinte combinação de etapas:

A Clarificação - era e é empregada, para a remoção de sólidos suspensos (turbidez) nas águas; é constituído pelos seguintes processos: coagulação, floculação, decantação ou sedimentação, e a filtração. Feita a clarificação a água ainda não está adequada para ser consumida, necessitando do processo de desinfecção, pela cloração, seguido da flouretação, etapa adicional, utilizada para diminuir a incidência de cárie dentárias.

$\mathrm{Na}$ coagulação, a água passa por um depósito com o alcalinizante, (cal hidratado, para corrigir o pH da água) e o coagulante, o sulfato de alumínio, de

\footnotetext{
${ }^{258}$ Brasil, leis e Decretos. Decreto 24.643, de 10 de julho de 1934, que cria o Código de Águas, e dá outras providências. Substituído somente em 1997, pela Lei 9.433, a chamada "Lei das Águas", de 8 de Janeiro de 1997, que institui a Política Nacional de Recursos Hídricos, e dá outras providências.

${ }^{41}$ Brasil, leis e Decretos. Portaria no 36, de 19 de Janeiro de 1990, do Ministério da Saúde. Aprova normas e o Padrão de Potabilidade da Água destinada ao Consumo Humano, a serem observados em todo o território nacional e dá outras providências. Diário Oficial de 23 de Janeiro de 1990.

${ }^{260}$ Brasil, leis e Decretos. Estabelece os procedimentos e responsabilidades inerentes ao controle e à vigilância da qualidade da água para o consumo humano, estabelece sue padrão, e dá outras providências.
} 
aplicação controvertida no final do século $X I X$ e começo do $X X$, em razão de não haver, naquela época, um consenso entre as autoridades da saúde pública, sobre seus efeitos no organismo humano, a longo prazo. Hoje, entretanto, é largamente empregado. Essas duas substâncias absorvem as partículas sólidas, impurezas, que estão na superfície da água, juntando-as em forma de flocos.

Após a mistura rápida, pela coagulação, a água segue para os tanques de floculação, onde é mantida em movimento de turbulências alta, média e baixa; as partículas então se juntam, provocando a formação de flocos, (floculação), resultantes da agregação das impurezas.

Após esse processo, ocorre a decantação (sedimentação), em que a mistura é deixada em repouso, nos tanques decantadores, A fase mais densa, processa-se por ação da gravidade, os flocos sendo mais pesados que a água, depositam-se no fundo do recipiente, sedimentam-se, formando uma camada de lodo que é periodicamente removida, através de lavagens ou descargas.

A última etapa é a filtração, que permite a eliminação de partículas e microorganismos que não se sedimentaram no decantador; a água, é então encaminhada para filtros de areia e carvão, formado por varias camadas. A água, de cima para baixo, passa primeiro por uma camada de carvão, a seguir por uma de cascalhos, depois por uma de areia grossa e, por ultimo, por uma camada de areia fina. Ao atravessar estas camadas, ficam retidos os flocos e impurezas que não foram eliminados no processo de decantação.

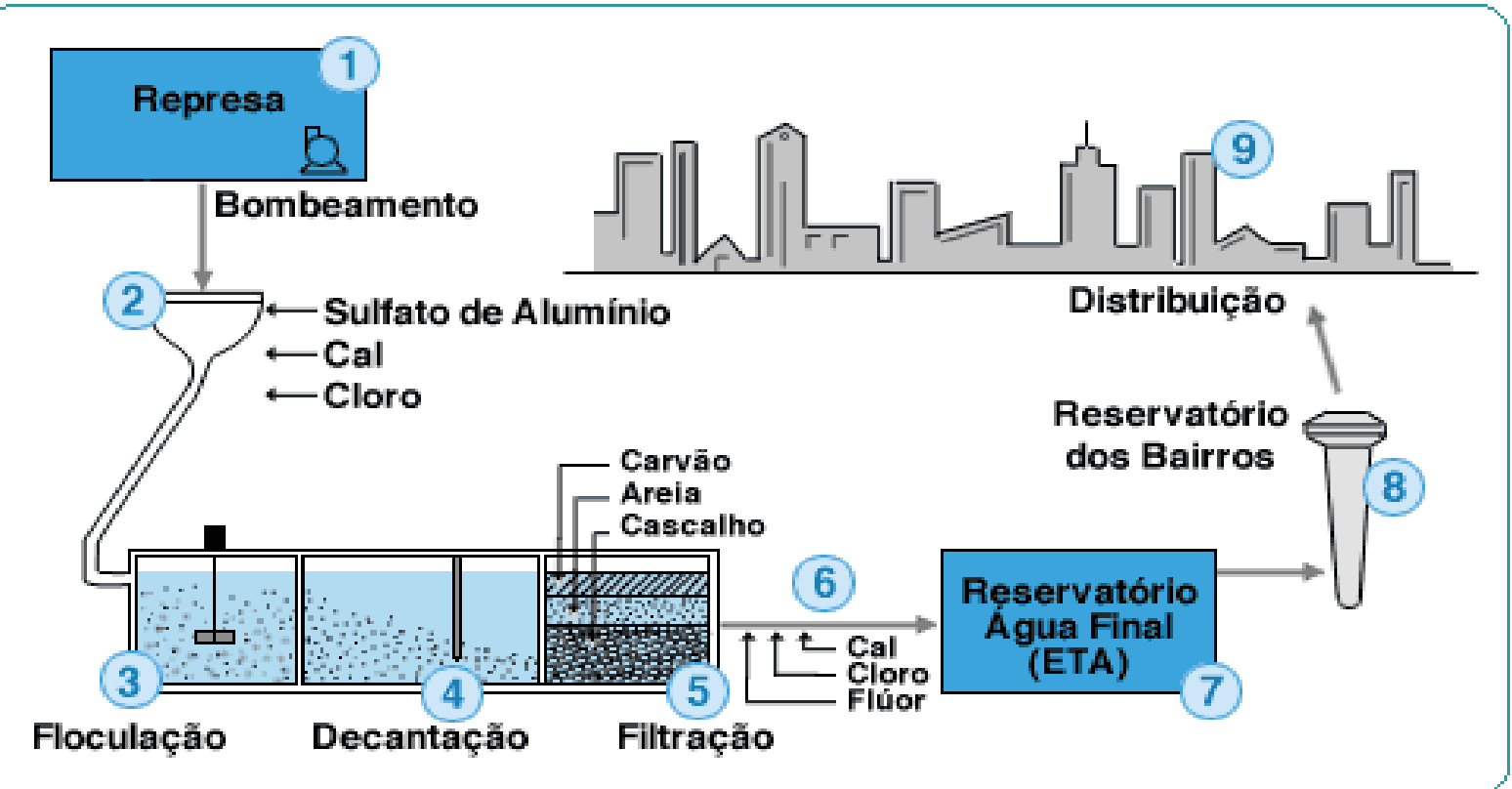

Sistema de Tratamento de Água 
Em seguida a água é submetida à desinfecção pela ação do cloro, (do qual falaremos mais adiante), para a destruição de microorganismos, e ao processo de fluoretação, pelo qual se adicionam compostos de flúor às águas para o abastecimento público, e como já se sabe, poderoso auxiliar na redução da cárie dentária.

Nos filtros lentos e contínuos, a questão da filtração, através de espessas camadas de areia, constituía, em finais do século XIX e começo do XX, o processo mais eficaz e recomendado para a distribuição das águas dos rios e das superficiais, de um modo geral.

Entretanto, vários inconvenientes em seu processo, originaram o aparecimento dos pré-filtros, que regularizavam a velocidade da filtração, para que se aproximasse, o mais possível, do regime ideal e por fim, os filtros submersos, que exigiam uma superfície maior para a filtragem, tornando o processo extremamente oneroso.

A solução viria com os filtros rápidos ou mecânicos, em que se utiliza um coagulante, geralmente o sulfato de alumínio, e também com os processos físicos e químicos de esterilização pelo ozônio (O3), e pela ação dos raios ultra violetas.

As experiências a respeito da purificação da água, não foram conseguidas em pouco tempo, ao contrário, as conquistas surgiram ao longo dos anos, na medida em que novas técnicas e dispositivos eram desenvolvidos no mundo inteiro, de tal forma que se garantisse a eficácia do abastecimento, e a potabilidade da água, nas condições mais imprevistas para seu fornecimento.

Durante o século XIX, progressos expressivos se fizeram sentir nos tratamentos preliminares com a "dégrossissage", ou decantação, e a coagulação, ou precipitação química, com os filtros de vários sistemas, submersos ou não, lentos e rápidos, simples e combinados, surgindo, recursos mais modernos para a época, como a esterilização das águas pelo ozônio, e pelos raios ultravioletas, aliados ao tratamento com o cloro, descoberto em 1774, pelo sueco Carl Wilhelm Scheele.

O cloro é um sistema antigo e ainda muito usado no tratamento da água; sua ação se dá por oxidação celular dos microorganismos, e pode ser aplicado sob a forma de gás, soluções de hipocloritos, dióxido de cloro e outras.

Inicialmente empregado na desinfecção das águas, somente em casos de epidemias, o cloro a partir de 1902, teve seu uso adotado de maneira sistemática na Bélgica. 
A cloração das águas públicas, foi introduzida nos Estados Unidos, em Jersey City, em 1908, e espalhou-se rapidamente, à medida que essa técnica se tornava altamente eficaz, na redução da incidência de mortes causadas por doenças comuns de propagação hídrica.

A popularidade do cloro é bem merecida, pois além de ser fácil de aplicar, dosar e controlar, mantém uma ação desinfetante residual durante a distribuição da água aos consumidores, após tratamento, é econômico, quando comparado com agentes desinfetantes alternativos.

A cloração aumentada, (tratamento de choque), é também uma medida típica para se corrigir o suprimento de água contaminada por enxurradas, como ocorre em muitas bacias hídricas.

Os processos de cloração, surgidos com a finalidade precípua da desodorização evoluíram com o tempo, e o primeiro composto clorado com esse objetivo foi o Hipoclorito de Sódio obtido pela decomposição eletrolítica do sal $(\mathrm{NaCl})$.

\subsubsection{Hipoclorito de sódio: aplicação pioneira}

Os relatórios da R.A.E., do começo do século $X X$, diziam que a água do Cabuçu era considerada de boa qualidade, francamente potável, e não necessitava de outro tratamento além da clarificação, acompanhada da completa eliminação de toda matéria sólida, e arejada pelo processo inglês dos crivos metálicos, que segundo resultados obtidos nas análises de água, dos países onde havia sido adotado, baixaria em torno de $50 \%$ a quantidade de matérias orgânicas em dissolução.

Já se encontrava em funcionamento normal, o clarificador Puech, construído para manter a pureza das águas do Cabuçu, mesmo em época de chuvas e as análises feitas no laboratório da Repartição de Águas e Esgotos, forneceram bons resultados, a ponto de ser classificada como a melhor água que se distribuía à cidade naquela época. ${ }^{261}$

\footnotetext{
${ }^{261}$ Relatório da Secretaria dos Negocios da Agricultura, Commercio e Obras Publicas do Estado de São Paulo, de 1907, apresentado ao Presidente do Estado pelo Secretário da Agricultura. Typographia Brazil de Rothschild \& Co., São Paulo,1908, p.291.
} 


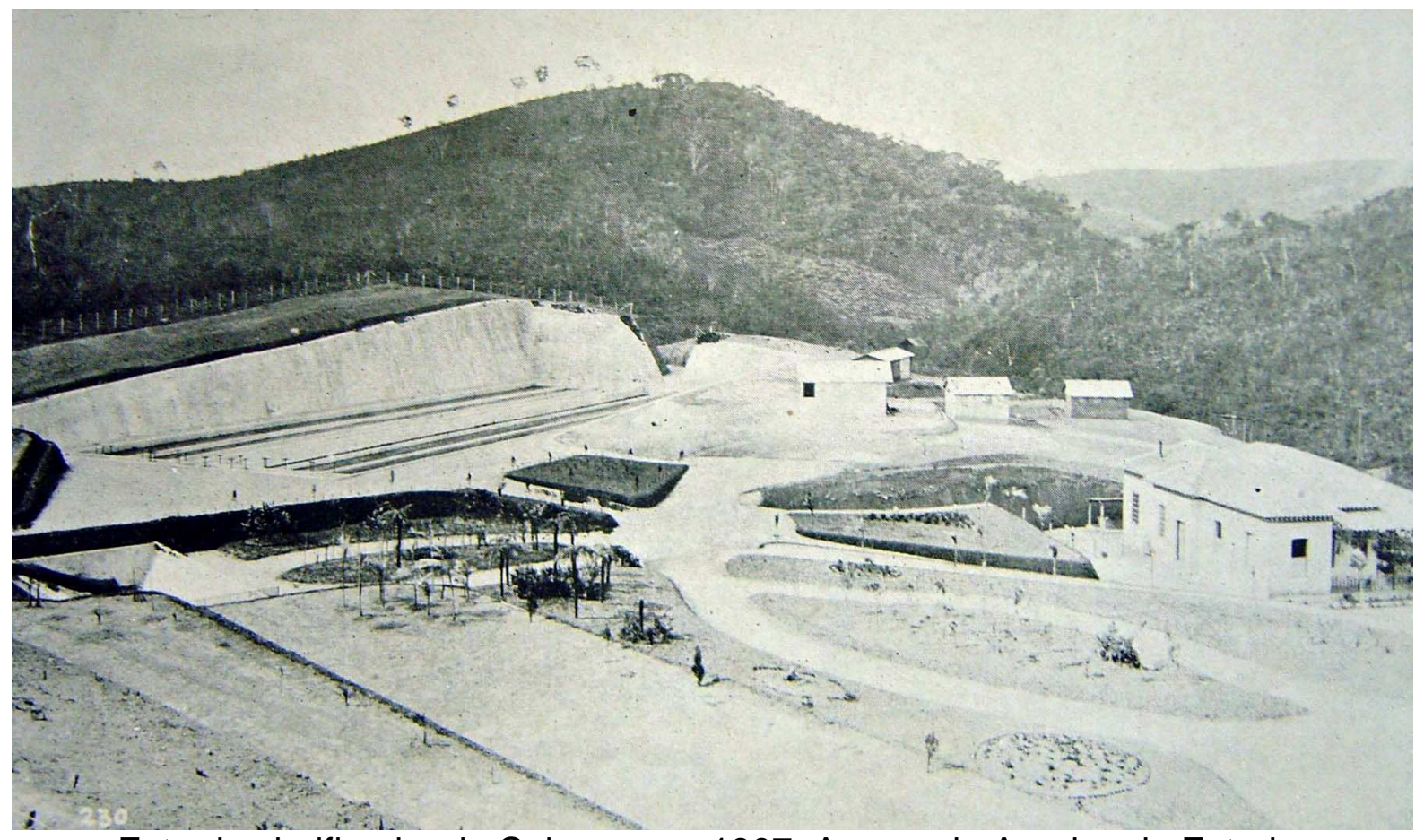

Foto do clarificador do Cabuçu, em 1907. Acervo do Arquivo do Estado.

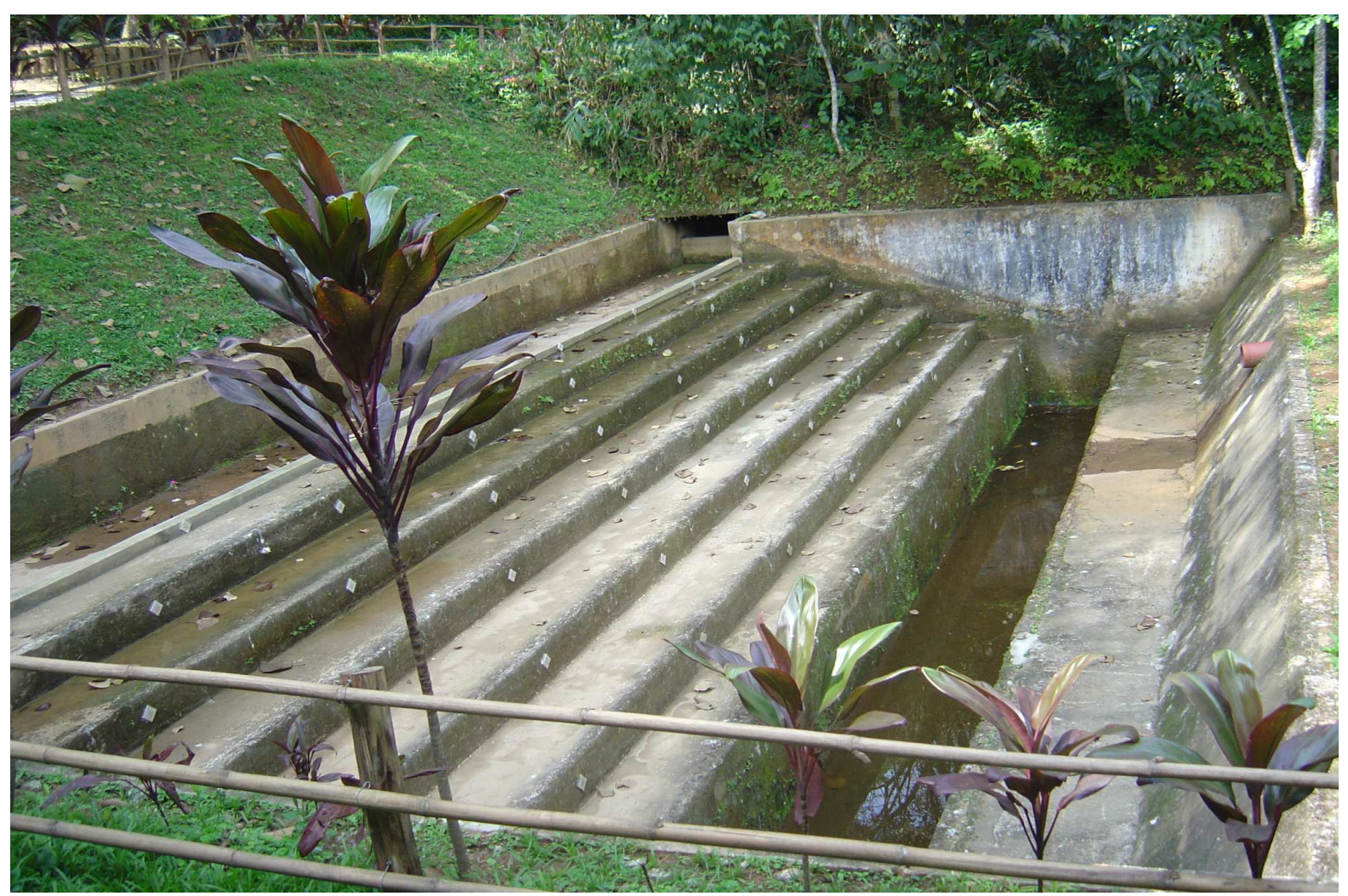

Foto do clarificador em outubro de 2006 


\section{Captação do Ribeirão Cabuçú}

Barragem n. 2 de concreto

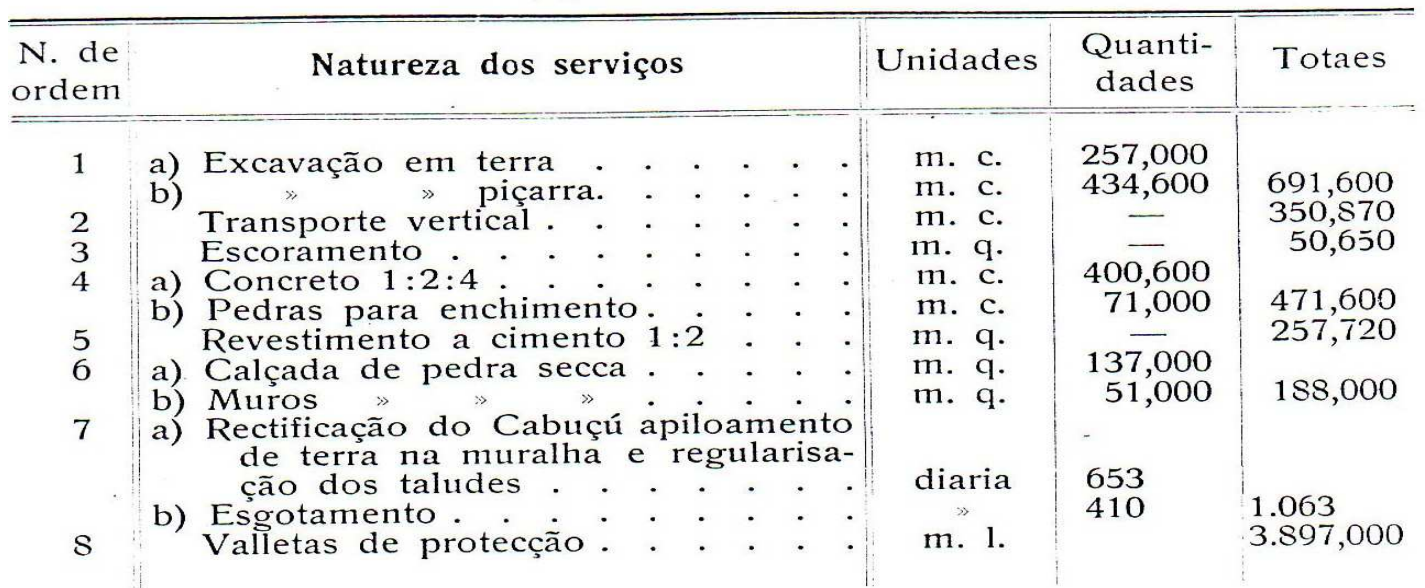

Filtração e Arejamento das Aguas do Cabuçú

Clarificador «Puech» e arejador em cascata (em concreto-armado)

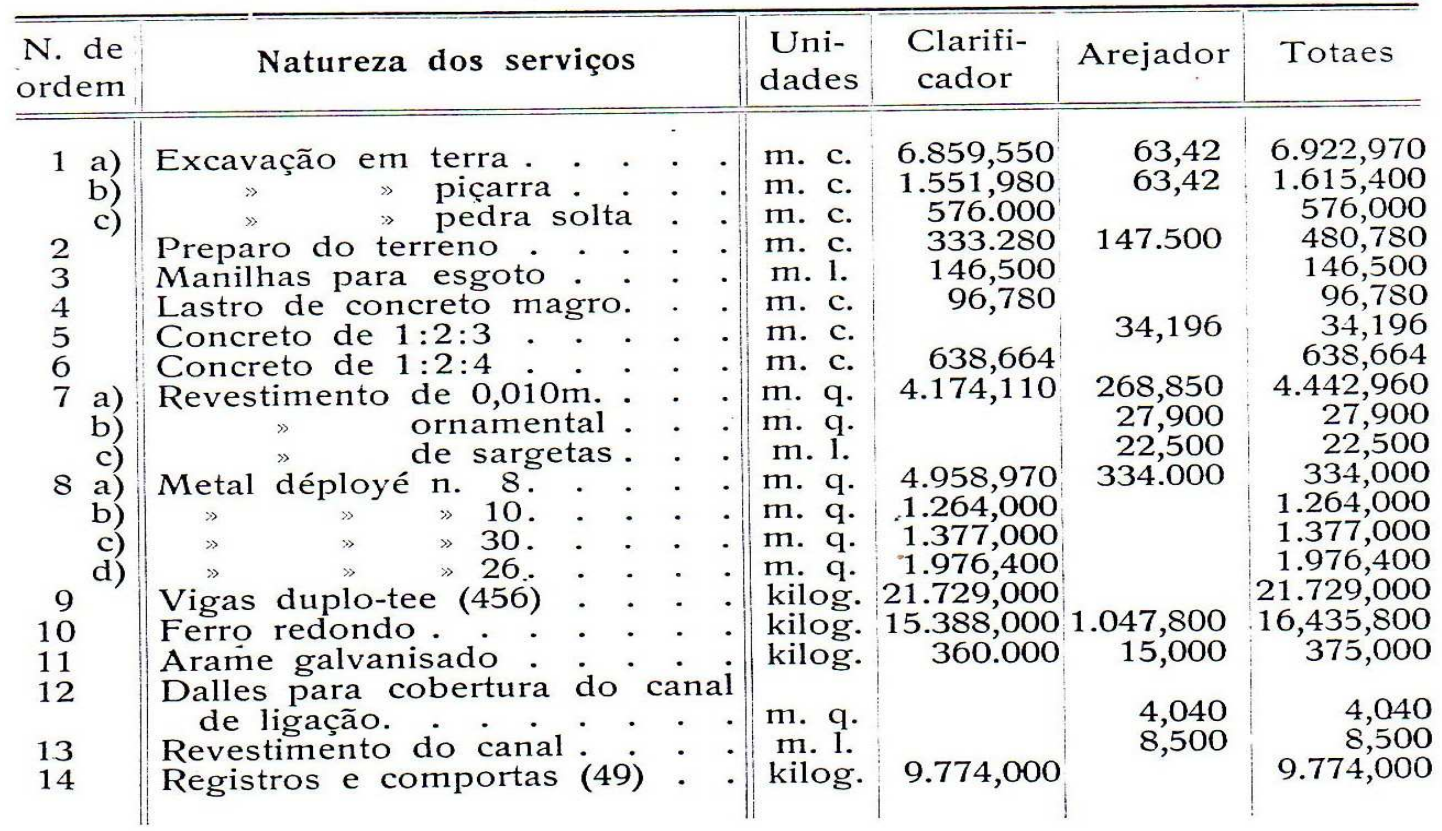

Demonstrativo dos materiais utilizados na captação,filtração e arejamento das águas do Cabuçu.

O tratamento de água é fator decisivo na prevenção das doenças de origem e de transmissão hídrica. Nesse sentido, buscando a destruição ou a inativação de germens patogênicos capazes de produzir essas doenças, e de outros organismos indesejáveis, vários processos de desinfecção da água foram desenvolvidos e aplicados, e em 1925, tem início a cloração das águas no Brasil, por iniciativa de Geraldo Horácio de Paula Souza, médico sanitarista. 
Em 1922, ao tomar posse como Diretor Geral do Serviço Sanitário do Estado de São Paulo, Paula Souza enfrentou, de imediato, um grave problema: a existência na Capital, de uma epidemia de febre tifóide, doença que apresentava elevado nível endêmico na cidade de São Paulo, a ponto de ter sido denominada no início do século anterior de "febre paulista". As medidas até então usadas, como conselhos educativos, vacinação e isolamento dos doentes e suspeitos, mostravam-se ineficientes.

Pesquisando a etiologia do surto epidêmico, o médico sanitarista, encontrou-a na água do Tietê, naquele momento usada como solução de emergência, e retirada à jusante, em local onde residia um portador da doença. Propôs uma medida radical: cloração da água do abastecimento público, na tentativa de mantê-la dentro de níveis seguros, reduzindo dessa forma os índices de mortalidade.

Muito combatido e criticado por aqueles que, como Arthur Motta, diretor da R.A.E., julgavam temerário o tratamento da água com o cloro, em razão de se desconhecer, entre seus elementos, qual deles detinha a propriedade bactericida, e quais seriam as conseqüências fisiológicas de sua saturação no organismo humano, com o passar do tempo.

Entretanto, prevalece a abalizada opinião de Paula Souza, e água foi sendo submetida ao tratamento pelo cloro, e desde então a febre tifóide teve sua incidência controlada, sendo erradicada, definitivamente em São Paulo, em 1929.

A cloração das águas é um dos métodos mais eficazes na prevenção de doenças. Associações técnicas mundiais, como a Organização Mundial da Saúde, recomendam com ênfase seu uso, como poderoso bactericida.

O uso de cloro no tratamento da água, pode ter como objetivos a desinfecção, (destruição dos microorganismos patogênicos), a oxidação (alteração das características da água pela oxidação dos compostos nela existentes), ou ambas as ações ao mesmo tempo. A desinfecção, é o objetivo principal e mais comum da cloração, o que acarreta, muitas vezes, o uso das palavras "desinfecção" e "cloração" como sinônimos.

Quando se iniciou a cloração das águas no Brasil, o reservatório do Cabuçu foi o pioneiro na aplicação do hipoclorito de sódio, (hipo-abreviatura de hipoclorito de sódio), também chamado de água de Javel, denominação antiga, proveniente do nome de um bairro, dos subúrbios de Paris, onde o químico Berthollet desenvolveu seus estudos sobre esse produto químico. 
Em 1820, Labaraque, também químico francês, conseguiu obter o hipoclorito de sódio com $2,5 \%$ de cloro ativo, e essa solução passou a ser utilizada como desinfetante de feridas.

A solução aquosa de hipoclorito de sódio, é usada como anti-séptico e alvejante, aplicada na desinfecção de qualquer tipo de água, de lagos, represas, rios, poços e fontes.

O hipoclorito de sódio (fórmula $\mathrm{NaClO}$ ), é produzido industrialmente pela decomposição eletrolítica de uma solução de cloreto de sódio (sal), tem cor amarelada, não é inflamável (não sofre combustão), e é higroscópico (não absorve a água do ambiente) . Está registrado na ONU sob número 1.791. ${ }^{262}$

Com alto poder bactericida, tem sido usado extensivamente no tratamento da água potável, de efluentes industriais, piscinas e outros. Para a desinfecção de água potável a concentração é de 1 litro de hipoclorito para cada 4000 litros de água. A quantia exata necessária, depende da química da água, da temperatura, do tempo de contato e da presença, ou ausência, de sedimentos.

A água tem influência direta sobre a saúde, a qualidade de vida e o desenvolvimento do ser humano. Para a Organização Mundial da Saúde (OMS) e seus países membros, "todas as pessoas, em quaisquer estágios de desenvolvimento e condições sócio-econômicas têm o direito de ter acesso a um suprimento adequado de água potável e segura".

"Segura", neste contexto, refere-se a uma oferta de água que não represente um risco significativo à saúde, que seja em quantidade suficiente para atender a todas as necessidades domésticas, disponível continuamente, e a um custo acessível. Estas condições podem ser resumidas em cinco palavras-chave: qualidade, quantidade, continuidade, cobertura e custo. Para atender a esses requisitos, o sistema público de abastecimento de água, deve ser bem projetado, construído, operado, mantido e conservado.

A água, um dos elementos fundamentais para a existência do homem, depois de utilizada para fins diversos, é devolvida ao meio ambiente parcialmente ou totalmente poluída, impregnada de substâncias tóxicas, materiais orgânicos ou microorganismos patogênicos, comprometendo a qualidade dos recursos hídricos

\footnotetext{
${ }^{262}$ ROSSIN, Antonio Carlos. Desinfecção, Técnica de Abastecimento e Tratamento da Água CETESB vol.III, São Paulo, 1987, p.886.
} 
disponíveis na natureza aumentando o risco de doenças que tem na água, seu principal agente causal. São elas:

Doenças de transmissão hídrica: aquelas em que a água atua como veículo para os agentes infecciosos, os microorganismos patogênicos, que a contaminam, através da excreção de pessoas ou animais infectados, causando problemas principalmente ao intestino humano. Essas doenças podem ser causadas por bactérias, vírus, fungos, protozoários e helmintos. Em geral esses microorganismos podem: ter seu habitat normal nas águas de superfície, terem sido levados pelas águas das enxurradas, provirem de esgotos domésticos, ou trazidos pelas chuvas na lavagem da atmosfera.

Doenças de origem hídrica: causadas por determinadas substâncias químicas, orgânicas ou inorgânicas, presentes na água em concentrações, em geral, superiores às especificadas nos padrões para águas de consumo humano. Podem ter origem nos contaminadores naturais de uma água que esteve em contato com formações minerais venenosas, ou na qual se desenvolveram determinadas colônias de microorganirmos tóxicos, ou que foram nela introduzidos em razão de obras hidráulicas defeituosas, principalmente nos tubos metálicos, ou de práticas inadequadas ao tratamento da água, como também aqueles agentes introduzidos na água, por detritos industriais.

São exemplos de doenças de origem hídrica: o saturnismo provocado por excesso de chumbo na água: a metemoglobinemia ${ }^{263}$ em crianças, decorrente da ingestão de concentrações excessivas de nitrato, e outras doenças com efeitos sentidos, a curto e a longo prazo.

Principais doenças de veiculação hídrica, provocadas por ingestão de água contaminada: Febre Tifóide, salmonella typhi, febre paratifóide, embora semelhante à febre tifóide, sua letalidade é muito mais baixa, gastroenterite, disenterias bacilar e amebiana, cólera, vibrio cholerae, hepatite infecciosa, giardíase, leptospirose e paralisia infantil.

Por contato com água contaminada:

Esquistossomose, tracoma ${ }^{264}$, escabiose ${ }^{265}$, verminoses ${ }^{266}$ e outras

\footnotetext{
${ }^{263}$ Problema que prejudica o transporte do oxigênio através das hemoglobinas. A literatura registra casos fatais em crianças de até seis meses, que consumiram água de poço, com excesso de nitratos. ${ }^{264}$ mais frequentes nas zonas rurais

${ }^{265}$ doença parasitária cutânea, conhecida por Sarna.

${ }^{266}$ Tem na água, um estágio do ciclo da doença.
} 
Por meio de insetos que se desenvolvem na água: Febre amarela, dengue, filariose, ou elefantíase, malária e outras.

O tratamento da água, entretanto, implica a utilização de substâncias químicas que podem, por sua vez, afetar a saúde daqueles que a utilizam. O cloro, é o agente mais usado pois, em quaisquer dos seus diversos compostos, destrói ou inativa os organismos causadores de enfermidades; esta ação se dá à temperatura ambiente e em tempo relativamente curto. Sua aplicação é simples exigindo equipamentos de baixo custo. A determinação de sua concentração na água é fácil, sendo relativamente seguro ao homem, as dosagens normalmente adotadas para desinfecção da água, além de possuir uma ação residual, que a protege de posteriores contaminações.

Os riscos relacionados ao processo de cloração, estão associados muito mais aos seus subprodutos, do que aos agentes utilizados. Existe, normalmente, grande número de compostos orgânicos na água bruta. Estes podem reagir com o cloro livre, levando à formação de diversos subprodutos, entre eles os denominados trialometanos, por exemplo o clorofórmio, que é o composto mais estudado, e o encontrado em maior concentração que os demais, obrigando o controle de seu índice de tolerância, na água a ser consumida pela população.

Considerando-se a importância sanitária e econômica da água destinada ao abastecimento, principalmente pelo alto papel que representa na Saúde Pública, encarando-se a saúde em seu sentido amplo, de um estado de completo bem estar físico, mental e social, como definiu a Organização Mundial da Saúde, e considerando-se, à vista do exposto, a série de doenças relacionadas com a água, desnecessário seria, encarecer a necessidade e a conveniência dos serviços de abastecimento de água, que merecem toda a atenção, por parte dos órgãos governamentais, dos técnicos, e servidores públicos e privados, que se ocupam desses trabalhos.

A realização completa dos serviços de saneamento do meio ambiente, dentro de um adequado programa, onde suas diretrizes sejam devidamente equacionadas, permitirá ao homem atingir o "estado de saúde" em seu sentido pleno, usufruindo melhor sua existência, e atingindo a sensação de verdadeiro bem estar geral. 


\subsection{Proteção legal do reservatório}

Com 27,2 quilômetros metros de extensão, o Cabuçu de Cima nasce na Serra da Cantareira, e drena uma área de 130 quilômetros quadrados; é um rio estadual por emprestar seu traçado para delimitar as divisas municipais entre São Paulo e Guarulhos e dadas as características de seus contribuintes que são os córregos Paciência no Parque Edu Chaves e Piqueri na Vila Nilo e Santa Rita, Jacinto na Vila Galvão.

Represado pela barragem do Cabuçu, situada no Parque Estadual da Cantareira, cujas matas em virtude de sua função protetora de mananciais e do solo, são consideradas de Preservação Permanente por efeito do artigo $2^{\circ}$ do Código Florestal. Por outro lado, são consideradas como de domínio do próprio Instituto Florestal, a vista do item III, do artigo $2^{\circ}$, Seção I, do Decreto Estadual no 52.370, de 26 de janeiro de 1970, que estabelece que o Instituto Florestal deve "intervir no setor florestal, detendo o domínio das florestas de preservação permanente". ${ }^{267}$.

Em 04 de agosto de 1983, a Resolução 18, o CONDEPHAAT, através da Secretaria da Cultura em seu artigo 10: "Fica tombada a área da Reserva Estadual da Cantareira (...)". 268

Em 1994, o Programa MaB - Man and Biosphere da UNESCO, declarou o Parque Estadual da Cantareira "como área integrante da Reserva da Biosfera do Cinturão Verde da Cidade de São Paulo, com status de Patrimônio da Humanidade.

No alto curso do rio Cabuçu de Cima, no ribeirão do Engordador, e do Barrocada, e também nas cabeceiras de alguns fornecedores do córrego Tremembé, ocorre expressiva cobertura vegetal de mata, em áreas do Parque Estadual da Cantareira e do Parque Estadual da Capital (antigo Horto Florestal). O Parque da Cantareira ocupa $32 \%$ da área da bacia e seus limites não foram burlados por edificações ou outro tipo de ocupação.

Outra restrição à ocupação na porção Norte da bacia é o seu enquadramento na Área de Proteção aos Mananciais: $1^{a}$ - Lei Estadual 898 de 18-12-1975, já alterada pela Lei Estadual no $3.746 / 83 .^{269}$

\footnotetext{
${ }^{267}$ NEGREIROS, O.C. de, et al. Plano de Manejo para o Parque Estadual da Cantareira. São Paulo, Boletim Técnico do Instituto Florestal no 10, 1974, p.22.

${ }^{268}$ São Paulo, Leis e Decretos, Resolução 18, de 4 de agosto de 1983.0 Secretário Extraordinário da Cultura, nos termos do artigo $1^{\circ}$ do Decreto-lei 149, de 15 de agosto de 1969 e do Decreto 13.426, de 16 de março de 1979, resolve: Fica tombada a área da Reserva Estadual da Cantareira e Parque Estadual da Capital (Horto Florestal), gerenciada pelo Instituto Florestal.
} 


\section{O GOVERNADOR DO ESTADO DE SÃO PAULO.}

Faço saber que a Assembléia Legislativa decreta e eu promulgo a seguinte lei:

Art. $1^{\circ}$. Esta lei disciplina o uso do solo para a proteção dos mananciais, cursos e reservatórios de água e demais recursos hídricos de interesse da Região Metropolitana da Grande São Paulo, em cumprimento ao disposto nos Incisos II e III do art. $2^{\circ} \mathrm{e}$ Inciso VIII do art. $3^{\circ} \mathrm{da}$ Lei Compleme ntar 94, de 29 de maio de 1974.

Art. $2^{\circ}$. São declaradas áreas de proteção e, como tais, reservadas, as referentes aos seguintes mananciais, cursos e reservatórios de água e demais recursos hídricos de interesse da Região Metropolitana da Grande São Paulo: I.

II. reservatórios do Cabuçu no Rio Cabuçu de cima, até a barragem no Município de Guarulhos;

III. reservatórios de Cantareira, no Rio do Cabuçu de Baixo, até as barragens no município de São Paulo.

2a - Lei Estadual 1.172 de 17-11-1976 e o Regulamento anexo ao presente Decreto, da Lei no 11.216 de 22 de julho de 2002 que altera essas disposições, e que também delimita as áreas de proteção dos mananciais, cursos e reservatórios de água de interesse da Região Metropolitana da Grande São Paulo: ${ }^{270}$

Art. 1․ Fica aprovado o Regulamento, anexo ao presente Decreto, da Lei ㄲo 11.216 de 22 de julho de 2002, que altera a Lei oㅜ 1.172 de 17 de novembro de 1976 .

Art. $2^{\circ}$. Este Decreto entrará em vigor na data de sua publicação. Regulamento da Lei no 11.216 de 22 de julho de 2002, que altera a Lei oํ 1.172, de 17 de novembro de 1976, que delimita as áreas de proteção dos mananciais, cursos e reservatórios de água de interesse da Região Metropolitana da Grande São Paulo.

TITULO I

Das Disposições Gerais

Art. 1‥ As disposições da Lei $n^{\circ} 11.216$ de 22 de julho de 2002, que altera a Lei $n^{\circ}$ 1.172 de 17 de novembro de 1976, que delimita as áreas de proteção dos

\footnotetext{
${ }^{269}$ São Paulo, Leis e Decretos. Lei Estadual 3.746 de 09 de Julho de 1983, que altera a Lei 898 de 18 de dezembro de 1975.

${ }^{270}$ São Paulo, Leis e Decretos. Lei no 11.216 de 22 de julho de 2002, que altera as disposições da Lei no 1.172 de 17 de novembro de 1976. Delimita as áreas de Proteção dos mananciais, cursos e reservatórios de água de interesse da Região Metropolitana da grande São Paulo.
} 
mananciais, cursos e reservatórios de água de interesse da região Metropolitana da Grande São Paulo, ficam disciplinadas nos termos deste Decreto.

Art. 2․ Para os fins previstos neste Regulamento, consideram-se sub-bacias hidrográficas aquelas contidas entre os divisores de água de escoamento superficial contribuintes dos seguintes mananciais de interesse da Região Metropolitana da Grande São Paulo:

I -...

II - reservatórios do Cabuçu, no rio Cabuçu de Cima, até a barragem do município de Guarulhos;

III -

Além da legislação específica de Proteção das Áreas de Mananciais o Cabuçu está situado em área tombada pela Resolução do CONDEPHAAT № 18 de 04 de Agosto de 1983. 


\section{CONSIDERAÇÕES FINAIS}

\section{- Preservação somente em caso de reutilização}

A Arqueologia Industrial, enfatizando seu caráter de disciplina científica que estuda as evidências industriais do passado, das técnicas e dos processos de produção, tem por objeto o estudo e a salvaguarda, de um patrimônio cultural, que integra outros vetores da realidade, até recentemente considerados de pouco ou nenhum valor, os bens industriais, que têm subjacente a intencionalidade de sua preservação, que deveria ser feita através da sensibilização coletiva do tecido social, para que pudesse ser conservada e difundida nossa herança industrial.

A noção de patrimônio, tem sofrido alterações significativas ao longo do tempo, e segundo Ferreira, amplia-se o campo semântico da palavra cultura, uma vez que progressivamente vão se integrando à sua realidade o que a ela responde $e$ corresponde: recentes ou remotas áreas de conhecimento, novas ou negligenciadas formas de experiência e de atividades, vestígios das mais antigas práticas rituais e artesanais, ou resultados das mais modernas conquistas tecnológicas, ou seja, o patrimônio industrial, ampliando conseqüentemente a área do que deve ser conservado, preservado, exposto e difundido como exemplo do que o homem tem feito ao longo dos séculos. ${ }^{271}$

O objetivo da Arqueologia Industrial é também o restabelecimento, e a restauração do monumento industrial e a reconstrução de suas partes destruídas, impedindo seu desaparecimento, e através de sua renovação, transformá-lo em objeto útil ao público. Deve converter-se na lembrança e na memória do passado, e também, constituir-se em um laboratório e sobretudo em fonte de informação, representando um patrimônio que possa transmitir um saber técnico à sociedade ou comunidade, onde está inserido.

Segundo Kühl, "existe hoje uma ampliação crescente e legítima daquilo que é considerado bem de interesse cultural a ser preservado, estendendo-se a um número cada vez maior, a tipos cada vez mais variados e a um passado cada vez mais recente". 272

\footnotetext{
${ }^{271}$ FERREIRA, D. M. Defesa e Valorização do Patrimônio Cultural Português. In Boletim da Secretaria do Estado da Cultura, 끄 5. Editora da Secretaria da Cultura, Lisboa, 1977.

${ }^{272}$ In ARTIGO DO PATRIMÔNIO, Revista Eletrônica do Instituto do Patrimônio, Histórico e Artístico Nacional (IPHAN), no4, Herança Industrial, de março de 2006, Disponível em: www.revista.iphan.gov.br. Acesso em: 21de outubro de 2007.
} 
Os pesquisadores voltados para a análise, no âmbito da cultura material, da ciência, da tecnologia, e do quotidiano, estenderam o campo conceitual do patrimônio cultural, onde o industrial, passa a ter relevância, uma vez que é difícil se analisar as diversas facetas do desenvolvimento humano, particularmente do mundo moderno, sem enfocar a ciência e a tecnologia.

É dentro desse contexto ampliado, que muitos exemplares do patrimônio industrial se enquadram, como é o caso da adutora do Cabuçu, que completou cem anos em $1^{\circ}$ de setembro de 2007.

O patrimônio não deve ser pensado apenas na perspectiva da conservação, mas do ponto de vista das suas funções e significações de uma sociedade em mudança. É preciso compreender as dimensões ambiental, de ordenamento do território, de habitat, de coesão social e de diversidade cultural. ${ }^{273}$ (MARTINS, 1983)

Pode-se considerar este monumento, como produto da revolução industrial, e seus vestígios ainda são encontrados na superfície, em algumas ruas dos bairros do Jaçanã, Tucuruvi e Santana, Zona Norte da cidade de São Paulo, semi-destruídos, atravancando ruas, definindo pequenas praças, e formando faixas de área verde, como se fizessem parte da paisagem.

\footnotetext{
${ }^{273}$ MARTINS, de Oliveira. In As populações e o Patrimônio. Que Desafios? Que Responsabilidades? Revista Munda n ․ Editora GAAC, Coimbra, 1983, p.63.
} 


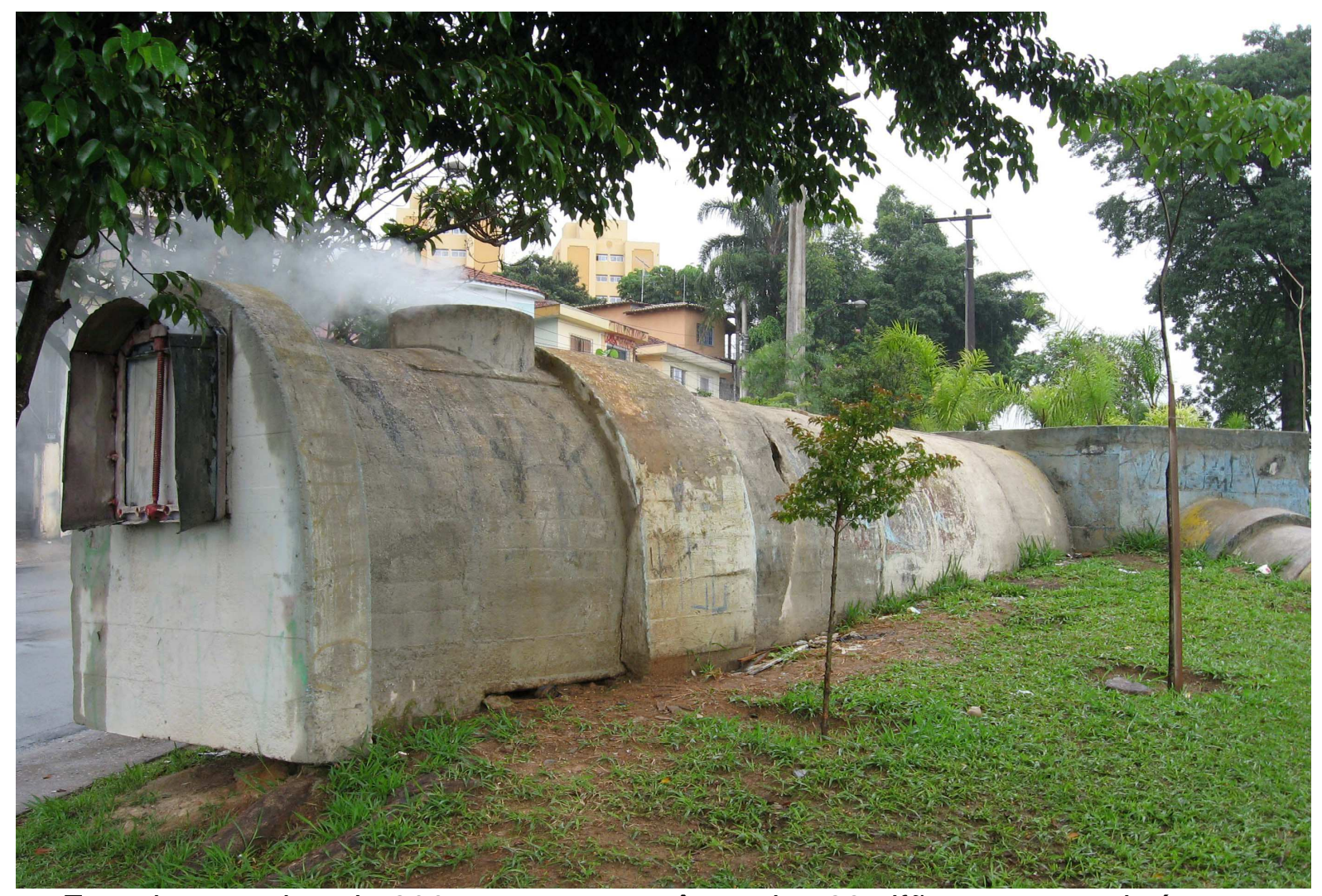

Foto de setembro de 2007, em que se vê um dos 28 sifões que constituíam o sistema de adução.

Os moradores de seu entorno, em inquérito oral, chegaram a afirmar que nunca haviam percebido sua existência, e ficaram surpresos ao saber que se tratava de uma das maiores obras de engenharia, do começo do século XX, construída para conduzir as águas do reservatório do Cabuçu à zona baixa da cidade, que até então consumia as do poluído Tietê, fornecidas com parcimônia e sem muita preocupação com sua potabilidade, ocasionando altos índices de mortalidade infantil.

Com a contribuição do Cabuçu, encerrava-se parte de um triste capítulo, a distribuição de um bem essencial, a água para os bairros proletários, que deveria ter sido feita em quantidade e qualidade necessárias à sua população, por tratar-se de um direito e uma prioridade, inalienáveis de toda a coletividade.

No caso da adutora, seu valor não se define apenas a partir de sua utilidade material, mas sim de sua capacidade de produzir informações. 
"La préservation des monuments implique toujours des valeurs immatérielles et c'est seulement l'intérêt social à les préserver ou à les faire connaître qui leur donne le droit d'exister". ${ }^{274}$ (WIRTH, 1985)

Esse monumento, apresenta, portanto, características de um gênero particular, fornecendo informações, cujo valor ultrapassa as fronteiras de sua importância individual, e o concentra em suas características construtivas peculiares, com o emprego de uma nova práxis construtiva, o concreto armado, de expressivo potencial, e de aplicação recente, nessa época, mesmo na Europa de onde se originou, entusiasmando os engenheiros brasileiros e possibilitando a solução de novas propostas arquitetônicas de grande beleza, e ousada engenharia, como foi o caso da barragem do Cabuçu, e seu sistema de adução.

No começo do século XX, a cidade de São Paulo expandindo-se em todas as direções, trazia sérias dificuldades com relação à colocação desses dutos que percorreram terrenos fortemente ondulados, com diferenças de cota, às vezes, de quase cem metros, e se fixaram em encostas escarpadas que dificultavam sua colocação, mergulharam em terrenos pantanosos, que obrigavam o desvio de córregos e sua drenagem, para finalmente, vencendo as barreiras naturais dos morros do Pedregulho, do Tucuruvi de o de Santana, chegar incólume ao seu destino final.

A sociedade deveria reconhecer seu valor, circunscrito às suas qualidades intangíveis, porque hoje não é mais possível reabilitar sua utilidade, e sua função material, que se perderam ao longo do tempo.

As novas técnicas substituem os equipamentos, então considerados obsoletos, por outros atualizados, e os condena ao descarte, sendo sucateada dessa forma parte da memória industrial, a "destruição criadora" de que falava Schumpeter, que se faz sentir na gestão da coisa pública, mais preocupada com o dia a dia e com o futuro, do que com a preservação da memória coletiva.

Em outros países, na década de sessenta, quando surgiu o movimento de conscientização, associado ao conceito de preservação do Patrimônio Industrial, uma das formas de conservá-lo, evitando a degradação, inexorável com o passar do

\footnotetext{
${ }^{274}$ WIRTH, Hermann. Principes Archéologiques Fondamentaux Pour la Préservation des Monuments Industriels. In L'Étude et la Mise en Valeur du Patrimoine Industriel. 4" Conférence Internationale. Lyon-Grenoble. Editions du Cente National de la Recherche Scientifique. Paris, 1985, p.121.
} 
tempo, era sua reutilização, que entre finalidades diversas, salientava a própria função industrial reabilitada, possibilitando a criação de inúmeros museus industriais.

Foi o caso do reservatório do Cabuçu, preservado e inteiramente recuperado com uma dupla função: fazer parte do Núcleo Cabuçu, área de proteção ambiental e de visitação pública do Parque Estadual da Cantareira, e ainda abastecer parte do Município de Guarulhos. Sua vistoria e diagnóstico, foram assinados por profissionais, do Instituto de Pesquisas Tecnologias, (I.P.T.), que fizeram o levantamento das condições da barragem em dezembro de 1981. De posse desse laudo, as firmas de engenharia se encarregaram da restauração e da colocação do reservatório em perfeitas condições para atender à demanda de um número considerável de consumidores daquela cidade.

A filosofia vigente, "reconverter", para preservar o patrimônio, não se aplica a certas estruturas do abastecimento de água, como é o caso da adutora, atualmente sem função utilitária, considerada morta, e vazia, como se tivesse sido congelada no seio dos espaços utilizados pelo homem.

Se, por um lado, a noção de que o aproveitamento generalizado de um monumento, representa um dos melhores meios para sua salvaguarda, em que pesem os desgastes que o uso intensivo possa provocar, é inerente o esforço de conservação, para que seja mantido utilizável, associado aos cuidados necessários com sua funcionalidade e limpeza.

A preservação da memória da adutora, entretanto, em temos locais, regionais e até nacionais é uma exigência da cultura contemporânea, parte significativa do patrimônio industrial, ainda que sua função utilitária não possa ser recuperada, e por via de conseqüência, não mais se obtenha qualquer valor monetário, sua relevância técnica, porém, considerada ímpar para a época de sua construção (1907), demonstra, de forma inequívoca, o grau de especialização da engenharia paulistana de então.

A adutora, portanto, pode ser considerada um patrimônio didático, e uma proposta de salvaguarda, nesse caso, resgataria o estudo da técnica empregada e sua evolução tecnológica, comparando-a com os sistemas de adução de outras épocas, e sua relação com a história da ciência e com a urbanização da própria cidade de São Paulo, conscientizando a população do entorno sobre a importância desse monumento. 
O patrimônio industrial, por sua natureza, características e potencialidades, tem sido objeto da análise e pesquisa de diversos tipos de cientistas e profissionais.

Nesse particular a arqueologia oferece um grande potencial explicativo, a partir do momento em que pode servir, com uma sólida orientação teórica, para criar novos dados a partir da colocação de novos problemas; por outro lado, pode oferecer uma explicação adequada de como se organiza um espaço produtivo e social, mediante o estudo intensivo e extensivo da zona em questão. ${ }^{275}$ (BARCELÓ, 1994)

Moberg, salientava que "a finalidade do trabalho dos arqueólogos não é a felicitação mútua pelas descobertas realizadas, mas sua divulgação, útil ao grande público, e à sociedade". 276

\section{- Democratização no abastecimento}

Na primeira década de 1900, as atividades econômicas da cidade de São Paulo já eram notáveis: café, agricultura, indústria, comércio e finanças, cresciam, integradamente, ampliando o potencial de acumulação do complexo financeiro paulistano.

A cidade se transformava em metrópole industrial, e sua formação, que se caracterizava fundamentalmente pela implantação de indústrias produtoras de bens de consumo, ainda no final do século XIX, estava vinculada à expansão e a diversificação do complexo cafeeiro.

A questão do suprimento de mão de obra e dos níveis salariais, parece ter sido de fácil solução, com a intensificação dos fluxos imigratórios para São Paulo. Depois que os cafeicultores solucionaram o grave problema do provimento de braços para suas lavouras, ficou praticamente resolvido o problema da demanda da mão de obra requerida pela indústria.

De 1898 a 1907, começa a ocorrer o fenômeno do êxodo rural, ocasionado pela crise cafeeira, e desse último ano, até 1910, a redução do plantio contribuiu, para que não houvesse pressões sobre o mercado de trabalho.

\footnotetext{
${ }^{275}$ BARCELÓ,M. Arqueologia medieval, En las afueras del "medievalismo". Apud CORDEIRO, J.M. L. ENCONTRO DE ARQUEOLOGIA URBANA.BRAGA. Arqueologia Industrial. Uma vertente fundamental da arqueologia urbana, 1994, p.172.

${ }^{276}$ MOBERG, Carl-Aexl. Introdução a Arqueologia. Editora Lisboa Edições 70, 1981, p.45.
} 
Uma série de fatores, portanto, se conjugaram para transformar São Paulo, de pequeno conglomerado, em uma cidade industrial, os lucros com a produção do café, o início da industrialização, a imigração, o movimento de pessoas, e o afluxo de capitais, nacionais e estrangeiros, a tal ponto que os fenômenos de mudança e expansão, pareciam trazer em si mesmos a força de sua propulsão.

Nessa época, a cidade era administrada por prefeitos oriundos da burguesia cafeeira, uma elite que ocupava cargos públicos e desejava seguir os modernos padrões de urbanização, que se praticavam em alguns países da Europa.

Nesse contexto, o núcleo central paulistano, considerado o eixo da rede de comunicações, limitado pelas várzeas do Tietê e do Tamanduateí, se expande, estendendo-se a locais, na época, ermos e longínquos, dando origem à formação de novos bairros.

Exemplo dessa assertiva, foi a ocupação progressiva pela alta burguesia, do espigão da Avenida Paulista, do bairro de Higienópolis, dos Campos Elíseos, e dos bairros-jardim, onde tentavam reproduzir o modelo de habitação "civilizado" e "ordeiro", adequado ao estilo de vida europeu.

A tentativa de europeização de São Paulo, ganharia um novo elemento, a arborização, feita sob a gestão de Antonio do Silva Prado, o primeiro prefeito da capital, que ordena o plantio de 25 mil árvores, de diversas espécies, que passaram a fazer parte da paisagem urbana.

Entretanto, a crescente economia paulistana utilizava mão de obra para suprir suas necessidades, que precisava ser alojada e não poderia, ao menos em princípio, ocupar com liberdade qualquer terreno, a terra tinha que ser comprada. A intensificação da especulação imobiliária, com a falência bancária do Barão de Mauá, fez surgir um novo tipo de aplicação financeira para a elite de São Paulo, o investimento imobiliário, surgindo uma nova ocupação do espaço urbano, com a conseqüente segregação sócio-espacial, o loteamento.

Outro fator decisivo remonta à lei de 1850, do Senador Nicolau Vergueiro, que determinava que a partir dessa data, todas as terras devolutas pertenceriam ao Estado, e sua ocupação, estaria sujeita à compra e venda. Com repercussões na zona urbana, a terra ate então barata, começa a se valorizar, restando aos trabalhadores as degradadas, enquanto a elite passa a se apropriar das melhores áreas para fixar suas moradias. 
O arco Tietê-Tamanduateí, com suas linhas férreas, e seus terrenos mais ingratos, tornou-se o espaço geográfico onde se instalaram os bairros proletários, e lá se fixaram os trabalhadores; esse espaço, com suas barreiras aquáticas, parecia um divisor natural entre a classe dominante, detentora do capital, e os trabalhadores, vetores potenciais de moléstias, segregados, com a normatização do uso da cidade pela elite, representada pelo Estado, que procurava gerenciar, através de intervenções técnicas, problemas e tensões, cujas raízes tinham suas origens, nos atritos sociais e de classe.

Segundo Taschner, citando a Lei no 315, (art. 7):

No caso de serem as habitações para proletários construídas em pontos afastados do centro da cidade, a Câmara procurará obter das ferrovias, da Companhia Light, da Estradas de Ferro e Bondes, o estabelecimento da condução apropriada com passagem a preço reduzido. ${ }^{277}$ (TASCHNER, 1982)

A urbanização paulistana foi produzida pela sociedade, ao mesmo tempo em que nela se manifestou, isto é, a urbanização materializa a sociedade no espaço e nele é possível ler as relações econômicas, políticas e culturais que o engendram. ${ }^{278}$ (MAIA COSTA, 2005)

Datam, portanto dos últimos anos do século XIX e começo do $X X$, a nova reordenação do espaço urbano com traços marcantes de segregação espacial, (separação das classes sociais nos espaços urbanos), consubstanciada no contraste marcante entre a formação dos bairros operários, e os loteamentos burgueses, que procuravam:

Produzir um modelo de civilização que se contrapunha não mais à escravidão, mas à marginalidade (...), ou seja havia uma rejeição em relação aos modos de viver da parcela de brasileiros pobres, tidos como inadequados para uma cidade que procurava se desenvolver segundo os moldes europeus de comportamento. ${ }^{279}$ (BESEN, 2003)

\footnotetext{
${ }^{277}$ TASCHNER, S.P. Moradia da pobreza: habitação em saúde. Tese de doutorado, 2 v., apresentada à Faculdade de Saúde Pública da Universidade de São Paulo, em 1982, p 77.

${ }^{278}$ MAIA COSTA, L. A. Planejando antes do planejamento: Território e Cidade em São Paulo, 18801910. In Desenhando a Cidade do Século XX. GITAHY, M.L.C. (org.). Editora Rima, São Paulo, 2005, p.33.

${ }^{279}$ BESEN, R. A feroz urbanização de São Paulo no início do século XX. In Revista histórica do Arquivo do Estado de São Paulo. Editora Imprensa Oficial, São Paulo, 2003, p.p.45/46.
} 
A fronteira entre os dois mundos ficou delineada precisamente; de um lado estavam os loteamentos exclusivos do Jardim América, Avenida Paulista, Campos Elíseos e Higienópolis, que possibilitavam aos paulistanos a convivência com seus pares, com seus iguais, e do outro lado, em outro mundo, estavam os bairros industriais do Belenzinho, Brás e Moóca.

No início do século $X X$, de um orçamento de 2.700 contos de réis que seriam gastos em obras públicas, "os Campos Elísios e a Consolação receberam 40,52\%, enquanto o Brás e a Moóca, ficaram com 3,70\%" deste total". 280

$\mathrm{Na}$ proporção em que a cidade expandia seus limites, o problema da desagregação se acentuava; os poderes públicos, implementando sua política de sanitarização, propunham como solução, a construção de casas unifalimiliares, as chamadas "Vilas operárias", ${ }^{281}$ que deveriam ser construídas pelos próprios industriais, com incentivos governamentais. A mais célebre delas foi a Vila Maria Zélia:

(...) construída na década de 1910, no Belenzinho, por Jorge Street, com a pretensão de formar uma comunidade de "bons operários" protegidos das agitações da grande cidade. Dessa forma as elites dirigentes confirmavam sua política de segregação das classes do trabalho e sua utopia de um São Paulo civilizada e aprazível. ${ }^{282}$ (CAMPOS, 2004)

Em São Paulo, no processo de ocupação de seu espaço geográfico, tanto as ações públicas quanto as privadas, impuseram à cidade, aspectos sócio-econômicos que definiram o lugar de cada um em seu interior, na perspectiva de se diferenciar a cidade idealizada, da construída, permeada de mazelas, pobreza e sujeira, que deveriam ser expurgadas do centro embelezado, e acabaram levando seus moradores para as áreas degradadas.

$\mathrm{Na}$ metrópole multicultural, portanto, não havia lugar para todos, e as transformações do espaço exigiam mudanças subjetivas, a reeducação das

\footnotetext{
${ }^{280}$ ROLNIK, Raquel. A Cidade e a Lei. Editora Studio Nobel/Fapesp, Coleção Cidade Aberta, São Paulo, 1997, pp.113-114.

${ }^{281}$ D'ÁVILA, S. Herança Operária. In São Paulo, 450. Histórias e Crônicas da Cidade na Folha.(org. Oscar Pilagallo). São Paulo teve em seu auge, depois da $1^{\text {a }}$ guerra mundial, 40 Vilas Operárias, segundo cálculos da arquiteta Telma de Barros Correira, professora do Departamento de Arquitetura e Urbanismo da USP-São Carlos e autora de uma pesquisa nacional sobre esse tipo de construção. ${ }^{282}$ CAMPOS, Alzira Lobo de Arruda. Vida cotidiana e lazer em São Paulo oitocentista. Apud História da cidade de São Paulo no Império 1823-1889. Org.Paula Porta.Ed.Paz e Terra, 2004, p.303
} 
pessoas, e o desenvolvimento de posturas inovadoras capazes de habilitar 0 paulistano a viver consigo mesmo, com os outros, e interagir com seu novo meio ambiente; a herança do passado já não era suficiente para que as pessoas participassem, plenamente, das atividades urdidas pela nova trama social.

"Sobretudo, nas primeiras décadas do século XX, a capital paulista tornou-se mais do que nunca o ponto de concentração dos caminhos e dos fluxos de pessoas e bens. Enriquecida, despontou como o universo no qual os novos modelos de viver, habitar, pensar e ser, foram desenvolvidos e difundidos". 283

Alguns elementos do novo complexo urbano: fábrica, estrada de ferro e as habitações operárias, constituíam a cidade industrial, cujos bairros passaram a esboçar uma nova tendência: o "modelo de periferia desequipada", no dizer de Rolnik . ${ }^{284}$

No decorrer do século $\mathrm{XX}$, o padrão de segregação, comum às metrópoles brasileiras, em termos de equipamentos urbanos, água, luz, esgoto, transporte público, é o que diferenciava o centro, da periferia.

Existe uma relação direta entre a pobreza, e a ausência de infra-estrutura urbana, o que ficou patente nos primeiros anos de 1900, quando a precariedade do abastecimento de água e do saneamento básico, as redes de esgotos, traziam sérios problemas de saúde à sua população, notadamente a infantil, cujos óbitos nos primeiros anos de vida, eram de tal monta, que no relatório do Serviço Sanitário de São Paulo ${ }^{285}$, seu diretor em 1896, dizia que se tirassem do obituário os números desses falecimentos, a Capital poderia ser considerada como uma cidade com as melhores condições de salubridade para se viver.

$\mathrm{Na}$ passagem do século XIX para o XX, adoecer em São Paulo era uma perspectiva assustadora e muito presente para a enorme parcela da população, que aliada às precárias condições de higiene e de serviços públicos, expunha os moradores da periferia à graves riscos de doenças como a febre amarela, tuberculose, varíola e outras, que vitimavam centenas de pessoas todos os anos. O processo da industrialização é o ponto de partida da problemática urbana, o

\footnotetext{
${ }^{283}$ TERRA PAULISTA, HISTÓRIAS, ARTE, COSTUMES. A FORMAÇÃO DO ESTADO DE SÃO PAULO, SEUS HABITANTES E OS USOS DA TERRA. Editora Imprensa Oficial, São Paulo, 2004, p.180.

${ }^{284}$ ROLNIK, R. Cada um no seu lugar!. Dissertação de mestrado apresentada à Faculdade de Arquitetura e Urbanismo da Universidade de São Paulo, 1981, p.37.

${ }^{285}$ COLEÇÃO DAS LEIS E DECRETOS DO ESTADO DE SÃO PAULO, Relatório da Secretaria do Interior, 1896, p.6.
} 
motor de transformações da sociedade, que induz a uma série de problemas relativos ao crescimento da população, seu planejamento, sua ocupação no espaço físico, o desenvolvimento da realidade urbana, sua infra-estrutura e todas as questões a ela pertinentes.

Logo se tornaram patentes os aspectos negativos da cidade capitalista: formação de uma estrutura fracionada, de caráter tentacular, cheia de áreas desocupadas e sem interligação entre as diversas partes; especulação fundiária intensa; expulsão das camadas populares dos espaços centrais, com degradação crescente da paisagem urbana". ${ }^{286}$ (CAMPOS, 2004)

Com a mudança na condução das obras públicas da cidade, principalmente no que dizia respeito ao abastecimento de água, que ao passar para a esfera pública, cria um conflito político, onde se aliam aspectos de ordem cultural e econômica para a população mais pobre; para os setores privilegiados, porém, a mudança não tinha o mesmo impacto, pois através dos aguadeiros, a água domiciliar já era cobrada.

Nesse período de sua história, de crescimento populacional intenso, marcado por profundas reformas urbanas, associadas a estiagens rigorosas e graves crises de abastecimento, São Paulo foi palco permanente de tensões, que percorriam cotidianamente seus espaços, refletindo uma história de muito conflito e intenso movimento social.

Segundo documentos oficiais, na primeira década de 1900, os arrabaldes não tinham água potável. Os bairros da zona baixa, eram abastecidos, como já se disse, pelo manancial da Água Funda, cujas áreas não desapropriadas estavam sujeitas à contaminação pelo rio Tietê, com suas águas poluídas, de qualidade duvidosa, o que explica o elevado números de mortes por doenças, que tinham um nexo causal com o tipo de água, distribuída àquela população.

A febre tifóide, doença cuja etiologia está diretamente ligada a potabilidade da água, tornou-se endêmica em São Paulo, aparecendo de tempos em tempos,

\footnotetext{
${ }^{286}$ CAMPOS E. São Paulo: desenvolvimento urbano e arquitetura sob o Império. In História da Cidade de São Paulo. A cidade na primeira metade do século XX: 1890-1954. Editora Paz e Terra S/A., São Paulo, 2004, p.245.
} 
epidemicamente, em finais do século XIX, e em algumas décadas do XX: 1913$1914,1920-1921$ e $1925-1925^{287}$

Eram insistentes e reiterados os pedidos dos Secretários da Agricultura, e dos diretores da Repartição de Águas e Esgotos, às autoridades do Estado para que medidas mais liberais fossem ventiladas, debatidas e postas em prática, pondo fim às imprevidências de administrações que não haviam tratado, com o devido respeito, uma questão tão importante, como era o abastecimento de água a esses bairros periféricos.

Essa postura se encontra definida no relatório de 1907, do Secretário da Agricultura, Carlos Botelho, feito ao Presidente do Estado, Jorge Tibiriçá: "a exemplo de meus antecessores, insisto em reclamar as necessarias providencias no sentido de se poder ultimar o serviço de distribuição de agua potavel nos arrabaldes que ainda se acham privados desse melhoramento. É indispensavel que sejam concedidos os necessarios recursos orçamentarios no sentido de completar esse serviço". 288

Porém passados dois anos, a situação permanecia a mesma, em razão de ainda estarem isoladas do abastecimento público, os três lagos artificiais Engordador, Guaraú e Cabuçu, que continuavam em observação, até que suas águas pudessem ser consideradas potáveis, e franqueadas à população, não havendo, entretanto, nenhuma outra iniciativa que cuidasse do problema do ponto de vista administrativo e humanitário.

No relatório de 1909, o Secretário da Agricultura, Antonio de Pádua Salles, dirigindo-se ao Presidente do Estado, Manoel Joaquim de Albuquerque Lins, afirmava "continuo exigindo providencias urgentes o serviço de distribuição de agua potavel nos arrabaldes da Capital. Para esse fim a Repartição de Aguas e Exgottos tem se ocupado com o estudo comparativo de possivel adducção dos manaciaes situados nos arredores da cidade, afim de que opportunamente se possa adoptar um plano satisfactorio para a solução do problema". ${ }^{289}$

\footnotetext{
${ }^{287}$ In RIBEIRO, M.A.R. História Sem Fim. Inventário da Saúde Pública. São Paulo - 1880-1930. Editora UNESP, São Paulo, 1993m p.245.

${ }^{288}$ Relatório da Secretaria dos Negocios da Agricultura, Commercio e Obras Publicas do Estado de São Paulo de 1907, apresentado do Presidente do Estado pelo Secretario da Agricultura. São Paulo, Tpographia Brazil de Rothschild \& Co., 1908, p.296

${ }^{289}$ Relatório da Secretaria dos Negocios da Agricultura, Commercio e Obras Publicas do Estado de São Paulode 1909, apresentado do Presidente do Estado pelo Secretario da Agricultura. São Paulo, Tpographia Casa Garraux, 1910, p.XLV.
} 
O Presidente do Estado, Albuquerque Lins, por sua vez, em mensagem enviada ao Congresso Legislativo em 1909, chama a atenção do Congresso, para assunto tão importante como era o prosseguimento das obras para que se completassem os serviços de águas e esgotos da Capital, que segundo suas palavras, ainda estavam longe de poderem dispensar a atenção da administração pública. ${ }^{290}$

Em 1910, o Vice Presidente do Estado, Fernando Prestes, em sua mensagem ao Parlamento Estadual, em razão da ausência no abastecimento dos três reservatórios, relatava que "fôram estudados comparativamente os mananciaes situados nos arredores da capital para que opportunamente sejam aproveitados no abastecimento de agua aos arrabaldes ainda privados de tão grande quão necessario melhoramento". 291

As intervenções públicas, através de obras que visavam melhorar a quantidade e a qualidade da água, direcionadas especialmente à zona baixa da cidade e aos seus moradores, talvez tivessem implícito o viés econômico, mais que o higienista. Os trabalhadores, se por um lado, não eram remunerados pelas horas perdidas com suas próprias enfermidades, e com os óbitos familiares, por outro, seu não comparecimento, dependendo do tipo de ocupação que desempenhava no setor produtivo, poderia representar prejuízo, para o empregador.

Para as condições higiênicas e sanitárias da São Paulo de então, o sistema de águas e esgotos está em uma relação de interdependência, como se o último dependesse essencialmente do primeiro, inferindo-se daí a importância do fornecimento de água, como uma questão vital.

As populações que por imprevidência, ou por outros motivos característicos da época enfocada, deixaram de ser atendidas, em tempo hábil, em suas necessidades de abastecimento adequado de água potável, não tardaram a pagar um preço alto por esse descuido, premissa comprovada nos altos índices de incidência de doenças e mortalidade, principalmente a de crianças, registradas pelas estatísticas demógrafo sanitárias desse período.

\footnotetext{
${ }^{290}$ MENSAGEM ENVIADA AO CONGRESSO LEGISLATIVO a 14 de Julho de 1909, pelo Dr.M.J. Albuquerque Lins, Presidente do Estado de São Paulo. Editora Duprat \& Comp. São Paulo, 1909. ${ }^{291}$ MENSAGEM ENVIADA AO CONGRESSO LEGISLATIVA a 14 de Julho de 1910, pelo Dr. Fernando Prestes, Vice-Presidente do Estado de São Paulo. Editora Duprat \& Comp. São Paulo, 1910.
} 
O problema do abastecimento de água em São Paulo, nos primeiros anos do século XX, além de elitizado, estava sujeito a soluções provisórias e parceladas, através de fórmulas bastante conhecidas. Se, por um lado, era uma realidade que o crescimento da cidade e o aumento significativo de sua população aconteciam de maneira intensa, excedendo a todas as previsões possíveis, por outro, não justificava a parcimônia das soluções, que de tempos em tempos, eram prescritas ou adotadas, para resolver um problema que periodicamente afetava os paulistanos, notadamente nos períodos de estiagem prolongada.

As águas da barragem do Cabuçu, então considerada o grande desafio da engenharia paulistana, chegaram finalmente em 1911, em quantidade e qualidade "democráticas", aos bairros da zona baixa, (cota 735), que com exceção da Luz, eram considerados proletários, Bom Retiro, Pari, Braz, Belenzinho e Mooca, proporcionando aos seus habitantes o acesso à água potável, que deveria ser garantido de maneira eqüitativa, como um direito básico de todos os paulistanos, independentemente da posição geográfica que ocupavam, em relação às zonas altimétricas em que a cidade então estava dividida, uma vez que, para as altas e altíssimas, (bairros nobres), estavam reservadas as águas da serra da Cantareira, célebres por sua tão decantada pureza.

Portanto, a relevância do sistema Cabuçu, dentro dos serviços de utilidade pública, como é o abastecimento de água, fica patenteada, não só pelas conquistas da técnica da engenharia de sua construção, e de seu sistema de purificação da água, como também, em razão da área que incorporou, abrangendo um grande contingente populacional, cujas condições de vida não poderiam prescindir de sua contribuição, para suas mais primordiais necessidades da existência.

“A água é necessária em todos os aspectos da vida. O objetivo geral é assegurar que se mantenha uma oferta adequada de água de boa qualidade para toda a população do planeta, ao mesmo tempo em que se preserve as funções hidrológicas, biológicas e químicas dos ecossistemas, adaptando as atividades humanas aos limites da capacidade da natureza e combatendo vetores de moléstias relacionadas com a água."292

\footnotetext{
${ }^{292}$ Capítulo 18 da Agenda 21. Proteção da qualidade e do abastecimento dos recursos hídricos: aplicação de critérios integrados no desenvolvimento, manejo e uso dos recursos hídricos.
} 


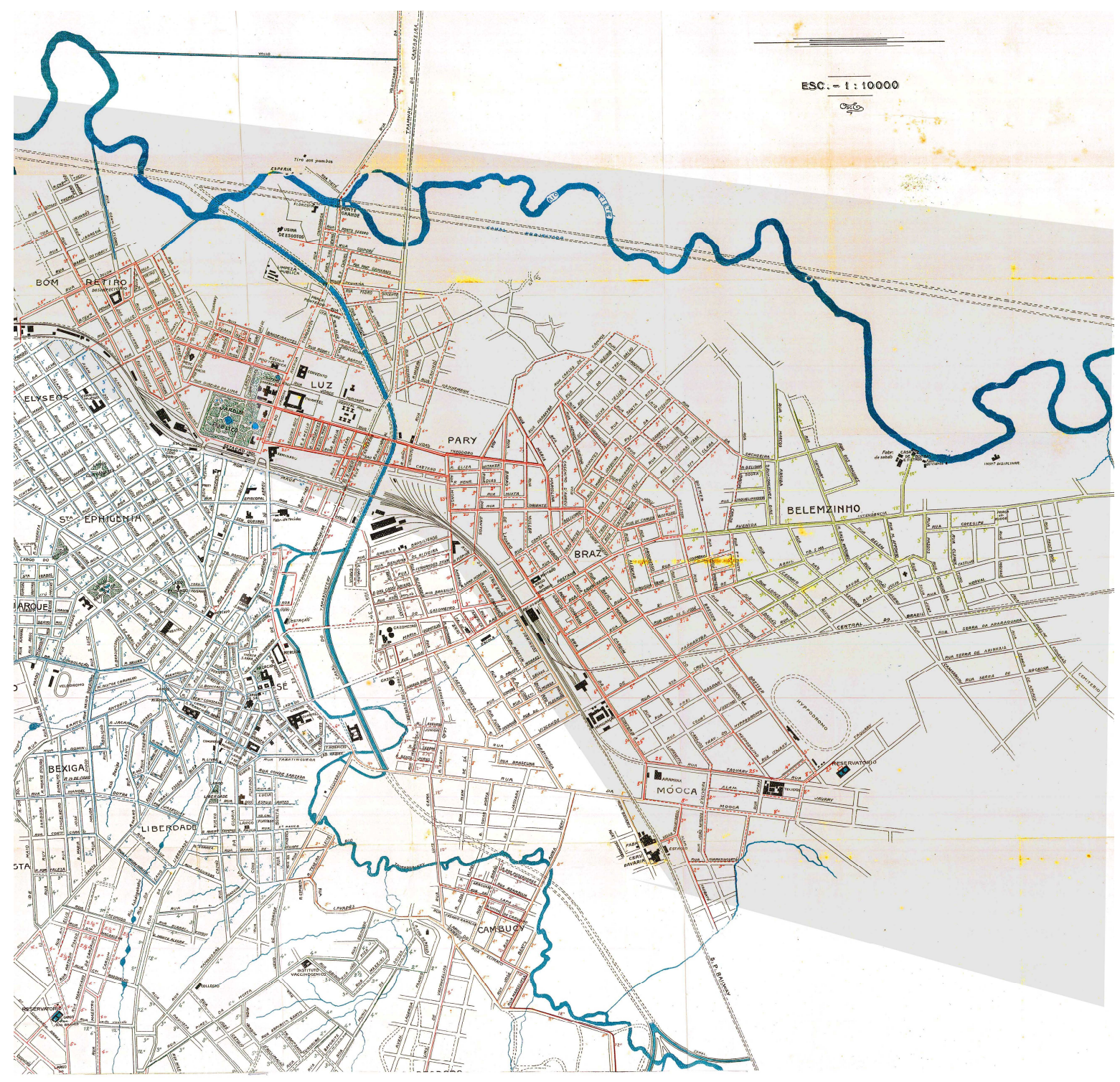

Repartição de Águas e Esgotos.Planta da cidade de são Paulo.Projeto de Revisão da Rede Distribuidora de Água. Escala 1: 10 000, 1905. (Na área em destaque os bairros da zona baixa: Luz, Bom Retiro, Pary, Brás, Belenzinho e Mooca, tributários do Cabuçu).

Vital para a sobrevivência das sociedades humanas, para a biodiversidade, e o desenvolvimento de diversas atividades econômicas, a água se torna progressivamente um recurso natural finito, tanto por sua disponibilidade quantitativa, quanto qualitativa para os diferentes usos sociais.

O consumo de água depende de vários fatores, como hábitos, poder aquisitivo, nível de educação, saúde da população, características climáticas, e seleção adequada dos sistemas de abastecimento e esgotamento sanitário. 
O estudo de sua utilização para o consumo, que hoje envolve não apenas engenheiros, mas biólogos, químicos, sociólogos, economistas, arqueólogos e outros profissionais, se torna importante para a memória das sociedades industrializadas. Desta forma, a pesquisa feita sobre a evolução dos sistemas de abastecimento e de tratamento de água, constitui em si mesma, uma forma de abordagem e de estudo das sociedades que os conceberam, e que por eles foram servidas.

De patrimônio natural, a água adquire, através de várias formas de utilização, a qualidade de patrimônio histórico, envolvendo a memória dos sistemas tecnológicos desenvolvidos ao longo de todo o processo de sua conquista.

A história da formação da metrópole paulistana, guarda estreita relação com o abastecimento público de água. No início de sua urbanização, esse abastecimento era estruturado sobre pequenas represas da Cantareira, preservadas não só em razão das características topográficas da serra, como também, pela política adotada em relação à propriedade das terras, onde se localizavam essas bacias, as primeiras adquiridas pela Companhia Cantareira, e as demais desapropriada posteriormente, pela Repartição de Águas e Esgotos (R.A.E.), garantindo assim, a salvaguarda das bacias hidrográficas do represamento.

No começo do século XX, deu-se um dos maiores fenômenos de crescimento urbano, que pode ser caracterizado inicialmente pelo desenvolvimento industrial, que transformou São Paulo no maior centro industrial da América Latina. Os agenciadores que lançaram as bases gerais desse processo, e que contribuíram para sua eclosão, são bastante conhecidos, e já citados: a abolição da escravatura, que aliada à intensificação da imigração estrangeira, deram origem à formação de um contingente humano, que rapidamente se transformou em numerosa clientela de produtos antes não consumidos, a facilidade na obtenção da energia elétrica, abundante e barata, depois da construção da usina de Parnaíba, a lavoura cafeeira, o encilhamento, a expansão dos meios de transporte, além de fatores de natureza externa como o primeiro conflito mundial de 1914/1918.

O crescimento demográfico resultante dessa industrialização, conduz a uma reflexão sobre os processos e as relações sociais, que constituíram a cidade nas primeiras décadas do século XX, principalmente a demarcação de seus novos limites espaciais e econômicos, resultantes de intervenções de caráter elitista na constituição do tecido urbano, em uma reordenação do espaço com traços de uma acentuada segregação espacial. 
A cidade se expande, e nessa mesma medida a segregação se acentua. As classes sociais estão separadas no espaço urbano, com desigualdades profundas de tratamento, por parte do poder público, no que se refere aos serviços essenciais. Ficavam assim patenteados os aspectos negativos da cidade capitalista.

Procurou-se demonstrar no trabalho, que a implantação da infra-estrutura, principalmente no que dizia respeito ao abastecimento de água, que constitui uma das pilastras básicas da engenharia sanitária, atendia aos anseios da classe dominante, e os arrabaldes abandonados, eram os que mais sofriam com sua falta, e principalmente com a potabilidade da que lhes era oferecida.

As alternativas enfocadas para a obtenção da água, demonstraram que os esforços do governo em tentar resolver problema tão sério, caminhavam lado a lado com o rol das intervenções normativas que foram feitas na ocupação do espaço, na criação dos Serviços Sanitários e na própria estruturação dos serviços de saúde, sempre com a preocupação em fornecer à nova sociedade paulistana, internacionalizada, a cidade desejada.

O represamento das águas dos rios e ribeirões da Cantareira, com a formação dos lagos artificiais, que tanto polêmica geraram no Brasil e no exterior, onde o sistema também estava sendo utilizado, tentava contornar o grave problema do abastecimento de água, cuja demanda sempre foi maior que a capacidade de atendimento, conforme se observou ao longo do trabalho.

Essas águas foram sendo gradativamente despoluídas, e a partir de 1911, oferecidas à população mais carente, na tentativa de reduzir doenças do aparelho digestivo, que tinham, com a qualidade água, um vínculo incontestável; febres gástricas, diarréias, colites, entero-colites, que grassavam particularmente nos bairros pobres, com um grande número de óbitos, principalmente entre crianças, que corriam o risco de vir a falecer com menos de um ano de idade.

Ressaltou-se também, a importância da engenharia brasileira do começo do século XX, com a construção da barragem do Cabuçu, e sua técnica arrojada, ao ser adotado o perfil elíptico do engenheiro norte-americano, Wegmann, (1896), que até então tinha sido usado apenas nos Estados Unidos, e a condução de suas águas, através de uma adutora em concreto armado de quase dezessete quilômetros de extensão, obras consideradas como as mais importantes do Brasil, daquela época

O pioneirismo também se fez presente com a utilização do concreto armado, sendo o Brasil o quarto país do mundo a adotá-lo em suas construções, tornando-se 
referência mundial no que dizia respeito à resistência dos materiais, método conhecido por brasilian test.

Foi também em São Paulo, nas águas do Cabuçu, onde se aplicou pela primeira vez, em 1925, um método revolucionário para a desinfecção da água com a solução do hipoclorito de sódio, substância que estava revolucionando o tratamento da água em todo o mundo.

O Cabuçu, desativado em 1976, foi inteiramente restaurado e preservado, em função de sua utilidade, fornecendo uma média de 214 litros por segundo, a 125.759 habitantes do Município de Guarulhos, em 2007.

Esperamos que os resultados finais desses estudos e pesquisas sobre tão importante patrimônio industrial, possam contribuir para uma atualização do Plano de Manejo do Parque Estadual da Cantareira, elaborado em $1974^{293}$ e possibilitem realizar um dos objetivos da Arqueologia Industrial, que é a salvaguarda dos testemunhos materiais do passado industrial de nosso país, que tem estreita relação com a conscientização da opinião pública sobre seu interesse histórico e cultural como é o caso do Cabuçu, objeto de intensa campanha para seu tombamento.

${ }^{293}$ NEGREIROS, Osmar Corrrêa de, et al. Plano de Manejo do Parque Estadual da Cantareira Boletim. Técnico do Instituto Florestal no 10.São Paulo, 1974, p 30. 


\section{BIBLIOGRAFIA CITADA}

ABITARE, no 158, Milano, Ottobre 1977

AFFONSO A. De Freitas. Diccionario Historico, Topographico, Ethonographico Illustrado do Município de São Paulo. Tomo I. Editora Graphica Paulista.São Paulo, 1929.

ALMEIDA, J..M. Diccionario Geographico da Provincia de São Paulo. Typ. A Vap. Espindola, Siqueira \& Comp. SP., 1902.

ARTHUR, Motta. Estudos Preliminares para o Reforço do Abastecimento D'Agua da Cidade de São Paulo. Typographia Brazil - Rothschild \& Co., São Paulo, 1911.

AZEVEDO, NETTO, José Manoel. Manual de Hidráulica.Edgard Blücher Ed. São Paulo,1957.

BARBIERI, Franco. Archologia industriale e storia dell'arte. In Archeologia Industriale. Indagini sul território in Lombardia e Veneto. Edizioni Unicolpli., Milano, 1989.

CORDEIRO, J.M. L.Arqueologia Industrial. Uma vertente fundamental da arqueologia urbana.Encontro de Arqueologia Urbana.Braga, 1994, p.172.

BARRAL I ALTET, Xavier. L'Archéologie de l'age industriel, Archéologie et Industrie. In: Les Dossiers de L'Archéologie. Dijon: Faton, 1986.

BERTOLLI Filho, Cláudio. Cenas de embarque. In Tietê Mãe das Águas. Editora CJE/ECA/USP. São Paulo, 1995, p.51.

BERTOLLI, Filho Claudio. A gripe Espanhola em São Paulo, 1918. Ed. Paz e Terra S/A. São Paulo, 2003.

BESEN, R. A feroz urbanização de São Paulo no início do século XX. In Revista histórica do Arquivo do Estado de São Paulo. Editora Imprensa Oficial, São Paulo, 2003.

BIERRENBACH, Gastão César. In Curso d'Água. Publicação da Companhia de Saneamento Básico de São Paulo (SABESP), 1988.

BLOCH, Marc. Caractéres Originaux de L'Histoire Rurale Française.S/E. Paris, 1935. BONDUKI, Georges Nabil. Origens do problema da habitação popular em São Paulo, primeiros estudos. Espaço \& Debates, v.2.no 5, São Paulo, 1982.

BRANCO, S.M. Henri Charles Potel e a Biologia das Águas de São Paulo. In Revista do D.A.E..Editora Diagrama Comunicações Ltda. São Paulo, 1964. 
BRANCO, Samuel Murgel et all. Episódios Pitorescos selecionados da História do Saneamento em São Paulo. In Revista do Departamento de Águas e Esgotos de São Paulo (DAE), São Paulo, no 147, vol. 46, 1986.

BRASIL. LEIS E DECRETOS. Decreto o 3349 de 17 de julho de 1899, onde o Poder Executivo concede autorização a The São Paulo Railway Light and Power Company, Limited para funcionar na República dos Estados Unidos do Brasil. Imprensa Nacional

BRASIL., LEIS E DECRETOS. Decreto 24.643, de 10 de julho de 1934, que cria o Código de Águas, e dá outras providências. Substituído somente em 1997, pela Lei 9.433, a chamada "Lei das Águas", de 8 de Janeiro de 1997, que institui a Política Nacional de Recursos Hídricos, e dá outras providências.

BRASIL., LEIS E DECRETOS. Portaria o 36, de 19 de Janeiro de 1990, do Ministério da Saúde. Aprova normas e o Padrão de Potabilidade da Água destinada ao Consumo Humano, a serem observados em todo o território nacional e dá outras providências. Diário Oficial de 23 de Janeiro de 1990.

BRAUDEL, Fernand. Civilização Material, Economia e Capitalismo. Ed.Martins Fontes, São Paulo, 1998

BRITO, F. S. Rodrigues, de. O Problema da Agua em São Paulo (Parecer). In Revista Viação, no especial, Rio de Janeiro, 1928.

Abastecimento de Aguas. Obras Completas de Saturnino de Brito. Vol.III. Editora Imprensa Nacional. Rio de Janeiro, 1943.

BUCHANAN, A. The Definition of Industrial Archaeology, In L'étude et la Mise en Valeur du Patrimoine Industriel. 4 $4^{\text {a }}$ Confèrence internationale.Lyon-Grenoble, Septembre 1981. Ed.du Centre National de La Recherche Scientifique. Paris, 1985.

BUCK, C. et al (orgs.) - The Challenge of Epidemiology - Issues and Selected Readings. HIPPOCRATES. Airs, Waters and Places. Washington D.C. Pan American Health Organization, Scientific Publication no 505, 1988.

BUENO, S. Vocabulário Tupi guarani-português .Ed. Nagy Ltda. 2ª .Ed. SP

CADERNOS de Saúde Pública. Vol. 3 no 1 Rio de Janeiro/Março de 1987.

CAMPOS E.São Paulo: desenvolvimento urbano e arquitetura sob o Império.In História da Cidade de São Paulo. A cidade na primeira metade do século XX: 18901954.Editora Paz e Terra S/A., São Paulo, 2004.

Campos, Alzira Lobo de Arruda. Vida cotidiana e lazer em São Paulo oitocentista. Apud História da cidade de São Paulo no Império 1823-1889. Org.Paula Porta.Ed.Paz e Terra, 2004. 
CARLOS, Ana Fani. A cidade e a organização do espaço apud BERTOLLI Filho Cláudio in A gripe Espanhola em São Paulo, 1918.Ed. Paz e Terra S/A São Paulo, 2003.

CARONE, Edgard. A República Velha. (Instituições e Classes Sociais).Editora Difusão Européia do Livro. São Paulo, 1972.

Carta de Nizhny Tagil de 2003, sobre o Patrimônio Industrial, elaborada pelo TICCIH (The International Committee for the Conservation of the Industrial Heritage,. Moscou 17 de julho de 2003

COLEÇÃO DAS LEIS E DECRETOS DO ESTADO DE SÃO PAULO de 1896, Relatório da Secretaria do Interior de 1896.

CORDEIRO, J.M.L. Arqueologia Industrial. Uma vertente fundamental da Arqueologia Urbana. In Encontro de Arqueologia Urbana, Braga, 1994.

. Um serviço centenário: o abastecimento domiciliário de água à cidade do Porto" (1887-1987), in Arqueologia Industrial, Museu da Indústria Têxtil da Bacia do Ave, Portugal, vol. 1, №. 1-2, 1993.

CUSTÓDIO, Jorge. Método Comparativo e Método Regressivo na Detecção do Moinho Gigante do Barão do Sobral erigido no Barreiro. In I Encontro Nacional sobre o Património Industrial. Editora Coimbra, vol. II, 1990, p.744.

D’ÁVILA, S. Herança Operária. In São Paulo, 450.Histórias e Crônicas da Cidade na Folha.(org. Oscar Pilagallo).Editora Publifolha, São Paulo, 2004.

DEBAUVE ,A. IMBEAUX, Ed. Distributions D'Eau. Assainissement Des Villes. Vve.CH.Dunod, Éditeur, Paris, 1905, Planche VI.

DEBAUVE A. e IMBEAUX. E. L'álimentation en eau et l'assainissement des Villes. Editora Bernard. Paris, 1902, 2 v.

DECLARAÇÃO DO GEHT, em defesa das construções e instalações utilitárias (Carta de Campinas) - UNICAMP, 1998.

SÃO PAULO. LEIS E DECRETOS. Decreto nº 233, de 2 de março de 1894, estabelece o Código Sanitário do Estado, e dá outras providências.

DENIS, Pierre. Le Bresil au XX e siècle 2.ed. Librairie A.Colin, Paris, 1928..

DUMAS, Maurice, apud ANDRIEUX, Jean-Ýves. Que sais-je? Le Patrimoine Industriel. Presses Universitaires de France, Paris, France, 1992.Enciclopédia Tecnologia Planetarium. Editora Roma Planetarium, Roma, 1976, vol. II.

ENGELS, Friedrich apud LAKATOS, Eva Maria. Fundamentos de Metodologia Científica.Ed Atlas, São Paulo 1991. 
FANNING, John Thomas. A practical treatise on hydraulic and water-supply engineering.relating to the hydrology, hydrodynamics and practical construction of water-works in North-America. Editora Van Nostrand, Nova York, $1906 .$.

FERREIRA, D.M. Defesa e Valorização do Patrimônio Cultural Português. In Boletim da Secretaria do Estado da Cultura, $\mathrm{n}^{\circ}$ 5. Editora da Secretaria da Cultura, Lisboa, 1977.

FOLGADO, Deolinda. Instituto Português do Património Arquitectónico: Inventário do património industrial. In Patrimônio Edificado. Novas tecnologias, Inventários. Editora do Insituto Açoriano de Cultura. Angra do Heroismo, 2002..

FOLWEL, Amory Prescott. Water supply engeineerin: the designing, construction, and maintenance of water-supply systems. Editora John Wiley and Sons, New York, 1900.

FONSECA, Filomena Pugliese. Dissertação de Mestrado: Equipamento do Engordador: Testemunho Arqueológico Industrial da Captação de Agua na Cidade de São Paulo. S.P.2003.

FREITAS, Antonio de Paula. Construcções em Cimento Armado. In Revista dos Cursos da Escola Politécnica do Rio de Janeiro.Editora da Escola Politécnica, Rio de Janeiro, 1904. vol I.

GARCIA, M. L. La Obra Publica, Investigacion Y Pratica. In I Encontro Nacional sobre o Património Industrial. Vol. II. Editora Coimbra Ltda. Coimbra, 1990.

GRIMAUD, De Caux, apud AMORIM, Alexandra Agra; PINTO, João Neves in Porto d'agoa. Instituto de Engenharia Superior do Porto, 2001.

HAZEN, Allen, in Relatórios da Repartição de Água e Esgotos de São Paulo, 1907/1908, apresentado ao Secretario da Agricultura pelo seu Diretor. São Paulo, Typographia Brazil-Rothschild \& Co., São Paulo, 1909.

HENRIQUES, Isabel. A Fábrica da Companhia de Cerâmica de Telheiras. Algumas questões de método. In I Encontro Nacional sobre o Património Industrial. Ed.Coimbra, Coimbra, 1990.

HENRIQUES, Luis Oliveira. A Iluminação a Gás da cidade de Leiria (1889-1904). In Arqueologia \& Indústria.Ed. Colibri. Lisboa, 1998.

HODDER, lan. Interpretación en Arqueología.Corrientes Actuales. Ed.Critica, Barcelona, 1994.

HOLANDA, Sérgio Buarque, de. Caminhos e Fronteiras. Cia. Das Letras, São Paulo, 1994.

HUDSON Keneth, Apud KÜHL, B.N. Arquitetura do ferro e Arquitetura Ferroviária em São Paulo: Reflexões sobre a sua preservação., Ed. Ateliê, São Paulo, 1998. 
HUDSON, Kenneth. Industrial Archaeology, an Introduction. Ed.John Baker Publishers, London, 1966.

JAUME Valentines Alvarez. Arqueologia Industrial I Ecomuseografia a Les Universitats. El Cãs de L'ETSEIB, In Quaderns d'Història de L'Enginyeria.Vol.VI, Barcelona, 2004.

JONES, William. Dictionary of Industrial Archaeology. 2ed.Sutton Publishing. London, U.K., 2006.

JORGE, Vitor Oliveira. Projectar o Passado. Ensaios sobre Arqueologia e PréHistória. Ed. Presença, Lisboa, 1987.

JORNAL O Estado de São Paulo, São Paulo, 08/06/1908.

ORDÓNEZ, José A. Fernández. Informe sobre la situación de la Arqueología Industrial y el Patrimonio de Obras Públicas en los países europeos del Mediterráneo y propuestas de acciojnes a emprender para su conservación y reutilización In Mercedes Lopez Garcia. La Obra Publica, Investigacion y Practica. I Encontro Nacional sobre o Património Industrial. Vol.II, Ed. Coimbra, Coimbra, 1990.

KÜHL, Beatriz Mugayar. Arquitetura do Ferro e Arquitetura Ferroviária em São Paulo: Reflexões sobre a sua preservação.São Paulo: Ateliê FAPESP, Secretaria da Cultura, São Paulo, 1998.

LEFÉBVRE, Henri. A Revolução Urbana.Editora UFMG, Belo Horizonte,Minas Gerais, 2004. O Direito à Cidade. Editora Moraes, São Paulo, 1991.

. De lo Rural a lo Urbano. Ed. Península, Barcelona, 1978

LEME, Luiz, Betim Paes. O Abastecimento de Agua Á Capital. In Revista Polytechnica de 1906. Typographia do "Diário Official", São Paulo, 1906.

LEMOS, F.C. Contribuição à História do Instituto Bacteriológico,1892-1940.Revista do Instituto Adolfo Lutz. São Paulo, vol.14, 1954.

MAIA COSTA, L. A. Planejando antes do planejamento: Território e Cidade em São Paulo, 1880-1910. In Desenhando a Cidade do Século XX. GITAHY, M.L.C. (org.). Editora Rima, São Paulo, 2005.

MARTINS, de Oliveira. In As populações e o Patrimônio. Que Desafios? Que Responsabilidades? Revista Munda ํㅡ 6, Editora GAAC., Coimbra, 1983.

MARX, Murillo apud Cidade das águas, KAHTOUNI Saide. Ed.Rima,São Paulo, 2004, Prefácio. 
MAS, François Barlatier De. Canaux. Encyclopedie des Travaux Publics Ed.Beranger. Paris, 1904.

MENDES J. Amado: Construção Civil e Patrimônio Industrial. Revista Munda. Editora Tipografia Comercial Coimbra. Coimbra, 1983.

MENDES, José Amado. A Arqueologia Industrial ao serviço da história local.In Revista de Guimarães, nº 105..S/E, Guimarães, Portugal,1995.

MENDES, José M. Amado. Património Industrial: um bem da comunidade ao alcance da escola. In Revista Munda nํ 16, Ed.GAAC. Coimbra, Portugal.. 1988.

MERHY, Emerson Elias.Capitalismo e a saúde pública :a emergência das práticas sanitárias no Estado de São Paulo. Ed.Papirus, Campinas, 1987.

MOBERG, Carl-Aexl. Introdução a Arqueologia. Editora Lisboa Edições 70, 1981.

MONBEIG, P. Aspectos geográficos do crescimento de São Paulo. In Jornal O Estado de São Paulo, 25-01-1954. São Paulo.

MOTTA, Arthur. Estudos Preliminares para o Reforço do Abastecimento D'Agua da Cidade de S.Paulo. Typographia Brazil-Rothschild \& Co.,São Paulo, 1911.

NEGREIROS, O.C. de, et al. Plano de Manejo para o Parque Estadual da Cantareira. São Paulo, Boletim Técnico do Instituto Florestal no 10, 1974.

OLIVEIRA, J.E.da Silva. Hydraulica. Lições dadas na Escola Militar do Brazil. Editora Imprensa Nacional, Rio de Janeiro, 1903.

OLIVEIRA, Walter Engrácia de, et all. Técnica de Abastecimento e Tratamento de Água.vol I. Abastecimento de Água. Editora da Companhia Estadual de Tecnologia de Saneamento Básico e de Defesa do Meio Ambiente (CETESB), São Paulo, 1976.

ORSER JR., Charles E.Encyclopedia of historical archaeology.Ed.Charles E.Orser J., New York, Routledge, 2002.

PALMER, Marilyn. Industrial archaeology: a thematic or a period discipline? In Antiquity Cambridge,Ed. Great Britain, 1990...

PANNELL, J.P.M. The Techniques of Industrial Archaeology. Ed.by J.Kenneth Major.Great Britain., 1974.

PETRONE Pasquale. São Paulo no século $X X$. In A cidade de São Paulo-Estudos de geografia urbana. v. II, s/d.Cia. Ed. Nacional, São Paulo.

PINARD, Jacques. L'archéologie industrielle. Presses Universitaires de France, 1985, Paris.. 
PRADAYROL, Jacques. Les chemins de Fer Touristiques .Pionniers de L'Archéologie Industrielle en France. In L'Étude et la Mise en valeur du Patrimoine Industriel. 4ํㅡㄹ Conférence internationale Lyon, Grenoble, Ed.du Centre National de la Recherche Scientifique, Paris, 1985.

QUEIROZ, Plínio. As Aguas para São Paulo. Diário Nacional, 1927, In Revista Viação, noo especial, Rio de Janeiro, 1928.

RAMOS, Reinaldo. Indicadores do Nível de Saúde no Município de São Paulo (1894-1959). São Paulo, 1962 Tese (doutorado) FSP/USP.

RELATÓRIO da MS. ENGENHARIA S/C LTDA Dezembro de 2000, enviado a VELLOSO FERREIRA, Consultoria e projetos S/C. Ltda. São Paulo, 2000.

SÃO PAULO, Relatório da Repartição de Águas e Esgotos. (R.A.E.) de 1907/1908, enviado a Secretário da Agricultura, pelo Diretor. Typographia Brazil - Rothschild \& Co., São Paulo, 1909.

.Relatório da Repartição de Águas e Esgotos de São Paulo, (R.A.E.), de 1906, apresentado, ao Secretário da Agricultura, pelo Diretor. Typographia Brazil de Rothschild \& Co.,São Paulo, 1907.

.Relatório da Repartição de Águas e Esgotos de São Paulo, (R.A.E.), de 1907, apresentado ao Secretário de Agricultura, pelo Diretor. Typographia BrazilRothschild \& Co. São Paulo, 1908..

.Relatório da Repartição de Águas e Esgotos de São Paulo, (R.A.E.) de 1909, apresentado ao Secretário da Agricultura, Comércio e Obras Públicas, pelo Diretor. Editora Casa Garraux, São Paul, 1910.

.Relatório da Secretaria da Agricultura, Comércio e Obras Públicas do Estado de São Paulo, de 1893, apresentado pelo Secretário ao Presidente do Estado de São Paulo. Typographia Espindola, Siqueira \& C. São Paulo, 1894.

.Relatório da Secretaria da Agricultura, Comércio e Obras Públicas do Estado de São Paulo, de 1904, apresentado pelo Secretário ao Presidente do Estado. Typographia Brazil de Carlos Gerke. São Paulo, 1905.

.Relatório da Secretaria da Agricultura, Commercio e Obras Publicas do Estado de São Paulo de 1905, apresentado ao Presidente do Estado pelo Secretário da Agricultura, Typographia Brasil de Rothschild \& Co., São Paulo 1906.

.Relatório da Secretaria de Estado dos Negócios da Agricultura, Comércio e Obras Públicas, de 1896, apresentado ao Presidente do Estado, pelo Secretário da Agricultura. Typographia Espindola, Siqueira \& C.São Paulo, 1897.

.Relatório da Secretaria dos Negócios da Agricultura, Comércio e Obras Públicas do Estado de São Paulo, de 1899, apresentado ao Presidente do Estado de 
São Paulo, pelo Secretário da Agricultura. Typographia do Diário Official, São Paulo, 1900.

.Relatório da Secretaria dos Negócios da Agricultura, Comércio e Obras Públicas do Estado de São Paulo, de 1900, apresentado ao Presidente do Estado de São Paulo pelo Secretário da Agricultura. Typographia do Diário Official, São Paulo, 1901.

.Relatório da Secretaria dos Negócios da Agricultura, Comércio e Obras Públicas do Estado de São Paulo, de 1902, apresentado ao Presidente do Estado de São Paulo, pelo Secretário da Agricultura. Typographia do Diário Oficial, São Paulo, 1903.

.Relatório da Secretaria dos Negocios da Agricultura, Commercio e Obras Publicas do Estado de São Paulo de 1909, apresentado do Presidente do Estado pelo Secretario da Agricultura., Tpographia Casa Garraux, São Paulo 1910.

.Relatório da Secretaria dos Negócios da Agricultura, Commercio e Obras Publicas do Estado de São Paulo de 1908, apresentado ao Presidente do Estado pelo Secretário da Agricultura, Typographia Casa Garraux , São Paulo, 1909,

.Relatório da Secretaria dos Negócios da Agricultura, Commercio e Obras

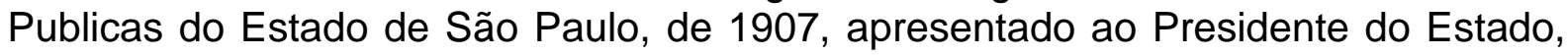
pelo Secretário da Agricultura.Typographia Brazil de Rothschild \& Co., 1908.

.Relatório da Secretaria dos Negócios da Agricultura, Commercio e Obras Públicas do Estado de São Paulo, de 1903 a 1906, apresentado ao Presidente do Estado, pelo Secretário da Agricultrua. Typographia Brazil de Rothschild \& Co.

Revista do Departamento de Águas e Esgotos de São Paulo, Ano XXXVI, no109, São Paulo, 1976.

Revista Eletrônica do Instituto do Patrimônio, PATRIMÔNIO Histórico e Artístico Nacional (IPHAN), nำ, Herança Industrial, de março de 2006, www.revista.iphan.gov.br..Acesso em 21-10-2007.

.Polytechnica II vol, 1906. Typographia do Diario Official, São Paulo, 1906.

.Polytechnica. Escola Polytechnica de São Paulo, VIII Volume, Typographia Brazil, de Rothschild \& Co. São Paulo, 1913.

Viação, Revista Technica, Mensal, Illustrada. Vol.Il. Número Especial, Rio de Janeiro, 1928.

Viação, Revista Technica, Mensal, Illustrada. Rio de Janeiro, 1927

Revue de L'Art de L'Ingénieur et de L'Hygiéniste Municipal. La Technique Sanitaire Année, nํs.9 et 10.Lyon, 1907. 
Revue Techonologique.Ed.Paris. Nouvelles annales de la construction. Paris, Août. 1899, Le Gérant: Ch. Béranger.

RHEINHEIMER, Gherhardt., Mikrobiologie der Gewässer, Ed. Veb G.F.V.Jena. De la edición em lengua española Ed. Acribia. Zaragoza, 1987.

RIBEIRO, Isabel e SANTOS, Luísa. A indústria do papel na perspectiva da Arqueologia Industrial. In I Encontro Nacional sobre o Património Industrial. Editora Coimbra, Coimbra, 1990.

RIBEIRO, Maria.Alice .Rosa. História Sem Fim... Inventário da Saúde Pública. São Paulo - 1880-1930.Editora UNESP, São Paulo, 1993.

ROLNIK, R. Cada um no seu lugar!. Dissertação de mestrado apresentada à Faculdade de Arquitetura e Urbanismo da Universidade de São Paulo, 1981.

ROSSIN, Antonio Carlos.Desinfecção, Técnica de Abastecimento e Tratamento da Água. CETESB vol.III, São Paulo, 1987.

RUSSEL, Harry Luman, e TURNEAURE, Frederick Eugene. Public water-supplies: Requirements, resources, and the construction of works. Editora John Wiley \& Sons. New York, 1903.

SAMPAIO, Teodoro. São Paulo no Século XIX e outros ciclos históricos. Editora Vozes Ltda. Petrópolis, Rio de Janeiro, 1978.

SÃO PAULO. Poder Exexutivo. Mensagem enviada ao Congresso Legislativo a 14 de Julho de 1909, pelo Dr.M.J.Albuquerque Lins, Presidente do Estado de São Paulo. Editora Duprat \& Comp. São Paulo, 1909.

Poder Executivo.Mensagem enviada ao Congresso Legislativo do Estado de São Paulo, a 14 de julho de 1910, pelo Presidente do Estado. São Paulo, 1911.

Poder Executivo.Mensagem enviada ao Congresso Legislativo do Estado de São Paulo, em 14 de julho de 1911, pelo Presidente do Estado. São Paulo, 1911.

Leis e Decretos. Decreto no 233 de 2 de Março de 1894. O Presidente do Estado, para a execução do artigo $3^{\circ}$ da Lei n 240 de 4 de Setembro de 1893, estabelece o Código Sanitário.de São Paulo e dá outras providências. Diário Oficial do Estado de São Paulo, cap.XV. Abastecimento de Água.

.Lei no 120 de 28 de outubro de 1891, cria a Inspectoria Geral de Higiene do Estado e dá outras providências. Typographia do Diário Official, São Paulo, 1891.

.Decreto 2141 de novembro de 1911, que reorganiza o Serviço Sanitário do Estado. de São Paulo e dá outras providências Título II art. 8․․

.Resolução 18, de 4 de agosto de 1983.O Secretário Extraordinário da Cultura, nos termos do artigo 1ํ do Decreto-lei 149, de 15 de agosto de 1969 e do 
Decreto 13.426, de 16 de março de 1979, resolve: Fica tombada a área da Reserva Estadual da Cantareira e Parque Estadual da Capital (Horto Florestal), gerenciada pelo Instituto Florestal.

.Leis e Decretos. Decreto № 1509, de 4 de setembro de 1907. Cria o Laboratório de Análises da Repartição de Águas e Esgotos de São Paulo, e dá outras providências.Typographia do Diario Official, São Paulo, 1907.

.Leis e Decretos. Lei Estadual 3.746 de 09 de Julho de 1983, que altera a Lei 898 de 18 de dezembro de 1975.

.Leis e Decretos. Lei o 11.216 de 22 de julho de 2002, que altera as disposições da Lei no 1.172 de 17 de novembro de 1976. Delimita as áreas de Proteção dos mananciais, cursos e reservatórios de água de interesse da Região Metropolitana da Grande São Paulo.

.Leis e Decretos. Lei no 43, de 18 de julho de 1892, regulamenta a criação do Serviço Sanitário do Estado de São Paulo, e dá outras providências. Typographia do Diario Official, São Paulo, 1892.

Leis e Decretos. Lei o 936 de 17 de agosto de 1904. Cria a Commissão de Obras Novas de Saneamento e Abastecimento de Água da Capital e dá outras providências.

SCHUMPETER, J.A. Capitalismo, Socialismo e Democracia. Ed. Fundo de Cultura. Rio de Janeiro, 1961.

SCHWARCZ, Lilia Moritz, in Virando o Vinte. Secretaria do Estado da Cultura, DEMA, São Paulo, 1994/1995.

SNOW, John. Sobre a Maneira da transmissão da cólera. $2^{-a}$ Ed.Imprenta São Paulo, Hucitec - 1990.São Paulo.

SPATARO Donato. Ingegneria Sanitária: provvista dell'acque e risanamento dell'abitato.Edição Vallardi, Milão, 1909.

SUZIGAN, Wilson et. Al. Crescimento industrial no Brasil: incentivos e desempenho recente. IPEA/INPES. Rio de Janeiro, 1974.

TASCHNER, S.P. Moradia da pobreza: habitação em saúde.Tese de doutorado, 2 v., apresentada à Faculdade de Saúde Pública da Universidade de São Paulo, em 1982.

TELAROLLI, Junior, Rodolfo. Poder e Saúde. A República, a febre amarela e a formação dos serviços sanitários em São Paulo. Tese de Doutorado (Doutorado em Saúde Coletiva) - Universidade Estadual de Campinas, 1993.

TELLES, Pedro Carlos da Silva. História da Engenharia no Brasil (Século XX), Editora: Livros Técnicos e Científicos, Rio de Janeiro, 1984 
Terra Paulista, histórias, arte, costumes. A formação do Estado de São Paulo, seus habitantes e os usos da terra. Editora Imprensa Oficial, São Paulo, 2004, p.180.

TROTTIER, L. Le patrimoine Industriel au Québec. Éd.Commission des biens cullturels du Québec.Canadá, 1987.

URTEAGA, Luiz. Miseria, miasmas y microbios. Las topografias medicas y el estudio del medio ambiente en el siglo XIX. Barcelona: Revista Geo Critica, n. 29, 1980.

VARGAS, Milton (organizador). História da Técnica e da Tecnologia no Brasil. Editora UNESP., São Paulo, 1994.

VASCONCELOS, Augusto Carlos, de. O concreto no Brasil. Ed.JAG.Composições e Artes Gráficas Ltda.São Paulo, 1985.

VITERBO, Souza Francisco. Arqueologia Industrial Portuguesa; os moinhos. In O Arqueólogo Português, Vol II, no 8 e 9, os 68 a 72, 1896.

WEGMANN, Edward, C.E. The Design and Construction of Dams. Ed.John Wiley \& Sons. Nova York, 1908.

WHIPPLE, George Chandler. The Microscopy of drinking water. Editora John Wiley, \&. Sons, 1907, Nova York..

WHITAKER, Plínio Penteado. Abastecimento de Água da Cidade de São Paulo. In Revista de Engenharia no 50, Vol. V. Editora Técnica Ltda. São Paulo, 1946.

WIRTH, Hermann. Principes Archéologiques Fondamentaux Pour la Préservation des Monuments Industriels. In L'Étude et la Mise en Valeur du Patrimoine Industriel. 4a Conférence Internationale. Lyon-Grenoble. Editions du Cente National de la Recherche Scientifique. Paris, 1985.

WOLMAN, Abel. Havia regras sobre Água Pura há 4.000 anos atrás. In Revista D.A.E., ano XX, no 23, São Paulo, 1958.

Agenda 21. Proteção da qualidade e do abastecimento dos recursos hídricos: aplicação de critérios integrados no desenvolvimento, manejo e uso dos recursos hídricos.

NEGREIROS, Osmar Corrêa de, et al. Plano de Manejo do Parque Estadual da Cantareira Boletim. Técnico do Instituto Florestal n 10.São Paulo, 1974. 


\section{BIBLIOGRAFIA CONSULTADA}

ALMADAN. Arqueologia e impacte ambiental.Editora Centro de Arqueologia de Alamada, Almada, Portugal, 1995.

ALVES, José Dafico. Manual de tecnologia do concreto. Editora. Livraria Nobel S/A. São Paulo, 1978.

ANDRIEUX, Jean-Yves. Le Patrimoine Industriel. Editora Presses Universitaires de France, 1992, Paris, França.

ARQUEOLOGIA \& INDÚSTRIA, Revista da Associação Portuguesa de Arqueologia Industrial, vols. 1, 2 e 3. Edições Colibri, Lisboa, 1999.

ASSOCIATION FOR INDUSTRIAL ARCHAEOLOGY. Industrial archaeology working for the future. Editora AB Printers limited, Leiscester, Great Britain, 1991.

BARBIERI, Franco e NEGRI, Antonello. Archeologia Industriale. Editora Scolastiche Unicopli via Verona. Milão, Itália, 1989.

BERTAGNON, Ricardo. Concreto dosado em central meio século de serviços ao Brasil. Editora Ópera Marketing, São Paulo, 2003.

BLOCH, Marc. Apologia da História ou o ofício de historiador.Editora Jorge Zahar, Rio de Janeiro, 1997.

CÂMARA MUNICIPAL DE LISBOA. D.João $V$ e o abastecimento de água a Lisboa. Editora Câmara Municipal de Lisboa, Portugal, 1990.

CAMDESSUS, Michel et all. Água. Oito milhões de mortos por ano. Um escândalo mundial. Editora Bertrand Brasil Ltda., 2005, Rio de Janeiro.

CARONE, Edgard. A evolução industrial de São Paulo. 1889-1930. Ed.Senac, São Paulo, 2000.

CORDEIRO, J.M.L.-. Museu Têxtil de Terrassa. Museu da Indústria Têxtil de Vila Nova de Famalicão, Portugal, 1991.

.Ecomuseu da região de Fourmies-Trélon, Museu da Indústria Têxtil, Vila Nova de Famalicão, Portugal, 1991.

Portugal, 1991.

.Museu Hidroeléctrico de Santa Rita.Braga: Câmara Municipal de Fafe,

Indústria e Paisagem na Bacia do Ave, Santo Tirso arqueológico, Santo Tirso II, 1992. 
.Bibliografia sobre arqueologia, patrimônio e museologia industrial. Arqueologia Industrial, Braga, Portugal, 1993.

.A ponte Pênsil (1843-1887), na perspectiva da arqueologia industrial, Gaya, Vila Nova de Gaia, Portugal, 1994.

.Patrimônio industrial português. Anais do $1^{\circ}$ seminário nacional de história e energia. Edição do departamento de patrimônio histórico da Electropaulo, São Paulo, 1988.

.A indústria conserveira em Matosinhos. Exposição de arqueologia industrial. Matosinhos, Portugal, 1989.

.(org.) da Revista de Arqueologia Industrial. Segunda e terceira séries, no 1 e 2 , Braga, Portugal, 1993, 1997.

COSTA, Luiz Augusto Maia. O ideário urbano paulista na virada do século.Editora Rima, São Paulo,2003.

CUNHA, Luiz Veiga da, et all. A gestão da água. Princípios fundamentais e sua aplicação em Portugal. Editora Fundação Calouste Gulbenkian. 1998, Lisboa, Portugal.

D'AMBROSIO UBIRATAN (org.). História da ciência e da tecnologia. Editora Nova Stella, São Paulo, 1988.

FUNDAÇÃO AGBAR. Aqua Romana-Técnica humana e força divina. Editora Museu Nacional de Arqueologia, Lisboa, Portugal, 2005.

GITAHY, Maria Lucia Caira. (org.) Desenhando a cidade do século $X X$. Editora Rima, São Paulo, 2005.

GOFF, Jacques Lê. Por amor às cidades. Editora UNESP, São Paulo, 1998.

GRANZIERA, Maria Luiza Machado. Direito de águas. Editora Atlas S/A., São Paulo, 2003.

GWYYN, David, PALMER, Marilyn Understanding the workplace Industrial Archaeology Review. Editora Great Britain, 2005.

JOAQUIM CAETANO. Aquedutos em Portugal. Editora Heska Portuguesa, S/A, Lisboa, Portugal, 1999.

LEITE, Rogério César de Cerqueira. A agonia da tecnologia nacional. Editora Duas Cidades, São Paulo, 1978.

MARINS, Paulo César Garcez. Através da rótula. Sociedade e arquitetura urbana no Brasil, séculos XVII a XX. Editora Humanitas, São Paulo, 2001. 
MORSE, Richard M. De comunidade a metrópole - biografia de São Paulo. Editora. Comissão do IV centenário da cidade de São Paulo, 1954.

MOTOYAMA, Shozo, (org.) Prelúdio para uma história- ciência e tecnologia no Brasil. Edusp, São Paulo, 2004.

Tecnologia e industrialização no Brasil-uma perspectiva histórica. Ed. Unesp. São Paulo, 1994.

O Arqueológo Português. Série IV.vol 11/12.Editora Museu Nacional de Arqueologia, Lisboa, Portugal, 1994.

PASSOS, Maria Lucia Perrone, (org.) Evolução urbana da cidade de São Paulo, 1872-1945. Ed.Eletropaulo, São Paulo, 1990.

PETRUCCI, Eládio Gerardo Requião. Concreto de cimento Portland. Editora Globo, Porto Alegre, 1978.

Primeiro Encontro Nacional sobre o Patrimônio Industrial, vols 1 e 2 . Editora Associação Portuguesa de Arqueologia Industrial, Lisboa, Portugal, 1986.

ROCHA, Aristides Almeida. Fatos históricos do saneamento.Editora João Scortecci, São Paulo, 1997.

TOLEDO, Benedito Lima de. São Paulo três cidades em um século. Editora . Livraria duas cidades. São Paulo, 1980.

TUNDISI, José Galizia. Água no século XXI: enfrentando a escassez. $2^{2}$ ed. Editora Rima, São Paulo, 2005.

VARGAS, Milton: História da ciência e da tecnologia no Brasil: uma súmula. Humanitas Editora, São Paulo, 2001.

WATER AUTHORITIES ASSOCIATION. The water heritage. Editora W.A.A.Londres, Inglaterra, 1985. 